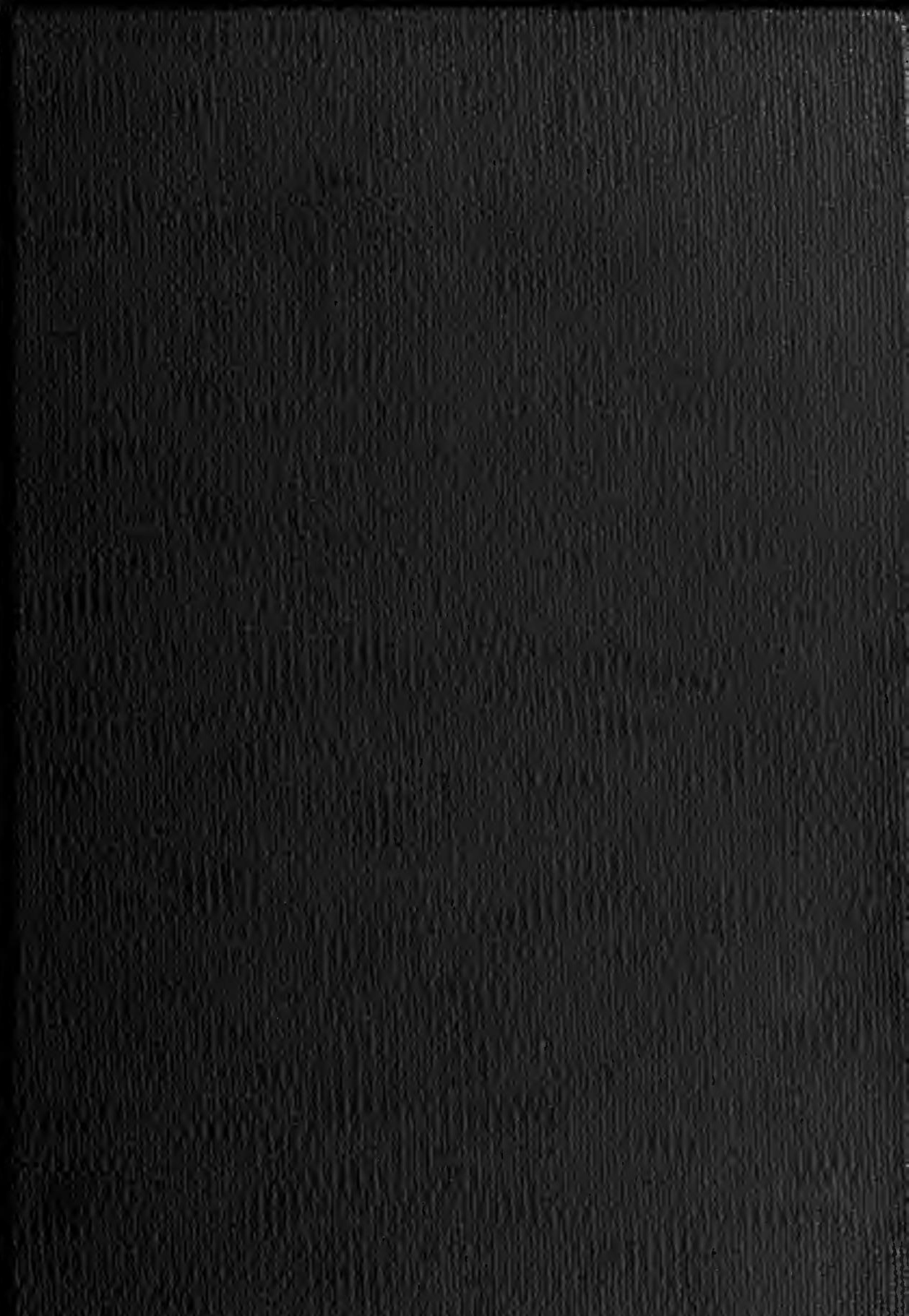





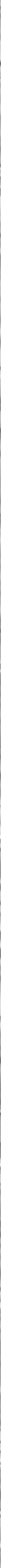




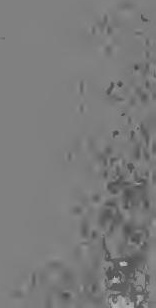


Digitized by the Internet Archive in 2007 with funding from Microsoft Corporation 


\section{THE RECONSTRUCTION OF RELIGION}




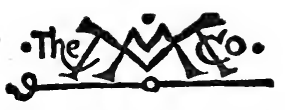

THE MACMILLAN COMPANY

NEW YORK - BOSTON - CHICAGO - DALLAS

ATLANTA - SAN FRANCISCO
MACMILLAN \& CO., LIMTTED
LONDON - BOMBAX - CALCUTTA
MELBOURNE

THE MACMILLAN CO. OF CANADA, ITD, TORONTO 


\title{
THE RECONSTRUCTION OF RELIGION
}

A SOCIOLOGICAL VIEW

\begin{abstract}
BY
CHARLES A. ELLWOOD, Ph.D.

Professor of Sociology in the University of Missouri. Author of "The Social Problem," "An Introduction to Social Psychology," etc.
\end{abstract}

3em Pork

\section{THE MACMILLAN COMPANY \\ 1922}

All rights reserved 
PRINTED IN THE, UNITED STATES OF AMERICA

Capraight, 1922,

BI THE MACMILLAN COMPANY

Set up and electrotyped. Published April, 1922. 


\section{To my son,}

\section{WALTER BRECKENRIDGE ELLWOOD,}

and to all of his generation, who have before them the heavy task of building a world of justice, good will, and peace. 



\section{PREFACE}

Is previous works the author has repeatedly said: "One of the greatest social needs of the present is a re- ligion adapted to the requirements of modern life and in harmony with modern science." ${ }^{1}$ Since the beginning of the Great War a number of the most dispassionate and detached thinkers of our time have expressed the same general idea. Two eminent British sociologists have recently expressed themselves thus: "We are compelled to the admission (one hard for the student, the man of pure or applied science), that the essential problem of life is not material, but psychical. In a word, life needs to be eupsychic; or in an older word, religious." 2 In May, 1916, Mr. G. Lowes Dickinson said in a private conversation with the author, "If I should guess, I would say that the great need of the world, just at present, is more religion. Of course, I mean religion of the right sort; of religion of a certain sort there is a plenty, but not enough of the right sort." 3 Again, in March, 1915, the author had the pleasure of visiting with Mr. Frederic Harrison, the veteran leader of the English Positivists. Mr. Harrison forcefully expressed the opinion that the Great War was due to the decadence of ethical religion, and that the problem of world peace and order would never be settled until the religious question was settled.

${ }^{1}$ See Introduction to Social Psychology, p. 273; The Social Problem, Revised Edition, p. 217.

2 Branford and Geddes, The Coming Polity, p. 242.

See also the statements in his work, Religion: $a$ Criticism and a Forecast. 


\section{PREFACE}

He has since expressed substantially the same view in recent books. ${ }^{1}$

Unlike the last two social thinkers just cited, the present writer would find the religion needed by the modern world in a more rational, revitalized, socialized Christianity. He agrees much more nearly with another eminent leader of Anglo-American ethical and religious thinking, who, though like the two preceding in his detachment from conventional religious circles, yet has found it possible to say: "Christianity, as soon as it has become transfused with the spirit and transformed by the method of modern science, will bring about the Millennium." 2 The thesis of this book, however, is rather that it is only a Christianity of this sort which is equal to the task of saving modern civilization, and of harmonizing its warring interests, classes, nations, and races. To this extent the author is in accord with those thinkers who see in a religious awakening the only hope of bringing our world back to social sanity and good will. ${ }^{3}$ But he would add that the religious spirit can be revivified only when religion is brought into harmony with men's unquestioned scientific beliefs and with their social needs-that is, into harmony with science and democracy. Intelligence rather

2 than emotion or tradition should guide, accordingly, in the religious life.

The modern world is completely torn asunder by conflicting ideals of life. It will continue to remain in this condition until there is some unity in social doctrine. But there is hope in all this confusion that the mass of men are coming to see that it is impossible for either

${ }^{2}$ See especially The German Peril, pp. 266-269.

2 Dr. Stanton Coit, The Soul of Ameriea, p. 247.

- See especially Kidd, The Science of Pover; also Patrick, The Psychology of Social Reconstruction, p. 286. 


\section{PREFACE}

individuals or nations to live together harmoniously upon the basis of the pagan and barbarous ideals of life which have been handed down in the traditions of our civilization and which some men, without adequate sociological knowledge, have endorsed. There is hope, in other words, that through calamity, if in no other way, men are slowly coming to a sense of the value of likemindedness and of good will among all men. Science, through its progressive demonstration of the truth in all fields of human interest, is slowly showing men how to achicve likemindedness as regards the essential problems of human living. But the program of applied social science cannot be carried out without good will among men; and herein lies the supreme importance of social religion. Religion concerns itself with social values. By intensifying and universalizing them it gives rise to the life-mood of human beings and thus furnishes a control which is competent to achieve universal good will. This, in the opinion of the writer, is the solution of the problem of securing adequate motivation for a better social order, which is so much debated at the present time; and if correct, it obviously places a heavy responsibility upon the Church.

The religious revolution of the last two generations, which undermined theological Christianity, however, has left the Church all but prostrate and powerless before the immense social task which now confronts it. "It is the object of this book to help show how the breath of life may again be breathed into its nostrils, and how the Church can again become that "spiritual power" which the world needs to energize and harmonize its life. To be sure, a host of goodly books are attempting, at this moment, to do the very same thing. The author would claim only the merit of a specific point of view-that of 


\section{PREFACE}

social science ${ }^{1}$-in adding his work to the many that already exist. It must be, however, the, social sciences to which the world must look more and more for guidance and hence to which religion also must look. The significance of the social sciences for religion, he believes, is not yet appreciated, and his task is to attempt to disclose, in part, that significance. He does not attempt, accordingly, to discuss specifically the metaphysical and theological questions which are usually raised whenever religion is mentioned. He attempts to discuss the reconstruction of religion only from a sociological, not from a philosophical or theological viewpoint. It is true that in a few places in the book rather definite theological views have been expressed. If these are found by any one to be bad theology, it will not affect the argument of the book. For it cannot be too strongly asserted that neither the vitality nor the social power of religion is bound up with the fate of any specific theological doctrine. This truth, to which both history and anthropology abundantly testify, needs emphasis especially in a period of religious reconstruction like the present. Religion must be freed from the trammels of theological dogmatism if it is to be free to develop in such a way as to meet the requirements of modern life.

In brief, religion as a practical program for dealing with the world's ills must be based upon social scienceit must be ever guided by growing social knowledge. On the other hand, social science must find its completion in social religion. These two should become but different aspects of one fundamental attitude in all normal, edu-

1 The term, "social science," as used in this book, refers not only to sociology, but to all the social seiences taken collectively, including anthropology, social psychology, social ethics and social philosophy, so far as these latter are based upon science. 


\section{PREFACE}

cated minds. The writer is not unaware of the dangers and difficulties of such a position. In the present condition of both the scientific and the religious world it may seem mere rashness to affirm that completed science leads to religion and that the conclusions of social science, moreover, are practically at one with those of the new social Christianity. Such a position can scarcely be expected to please the conservatives in either science or religion. The writer is willing to accept the full consequences of this position, and, in the words of a great humanitarian statesman, "to play for the verdict of mankind." He would go further and say that beyond the merely descriptive tasks of science are its tasks of evaluation, and that upon the social sciences especially rests the responsibility of guiding ethical and religious evaluations. $P$ It is the duty of the sociologist to aid in the solution of the religious problem. In a fully scientific world not only would a scientific man who had knowledge of the conditions of human living be expected to "preach" (as, indeed, we now expect our health experts to do), but "preaching" without scientific knowledge of human conditions would not be tolerated.

Some misunderstanding may perhaps be avoided if we say that science-that is, accurate, rationalized knowledge -cannot, of course, be everything in religion. Science, at most, can furnish but one of the bases of religion. Science is not religion, nor can it become a substitute for religion. Religion is and must remain essentially in the realm of faith; it necessarily transcends science, but it can and should become a rational faith, energizing men for better living both individually and socially, and seeking the aid of science, especially the social sciences, for the building of a better human world. That, again, in brief, is the practical plea of this book. 


\section{PREFACE}

The book is necessarily a book of value-judgments, of conclusions rather than mere facts. The facts upon which the conclusions are based will be found scattered throughout the literature of the social sciences, especially of anthropology and sociology. A few of the sources have been indicated in the citations in the foot-notes, and they are more fully indicated in the author's other published works, of which this volume may be considered an elaboration on the ethical and religious side. It is hoped also that the foot-notes may be found useful by those who wish guidance for further reading. The central argument of the book will be found stated in Chapters II, III, V, and XI. The other chapters elaborate or apply the viewpoints developed in these central chapters.

As the book attempts a constructive application of the principles of sociology and social psychology to the religious problem of our time, the theoretical principles made use of are naturally those stated in the author's Introduction to Social Psychology, and also, in a more brief and popular form, in his book, The Social Problem: A Reconstructive Analysis. The general philosophical background may best be found, by those who may be interested, in Hobhouse's Development and Purpose and his Morals in Evolution.

No citations are made from the Bible, not because the author has not a deep appreciation of the value of that book for the religious life, but because he wonld not profess to have any adequate equipment for technical New Testament interpretation, and even more because he wishes his work regarded solely as a work in applied social science. Such eitations, it is believed, would add little, if anything, to the value of the book. The reality with which the sociologist is eoncerned is the objective Christian movement; and the animating principle of that movement is xii 


\section{PREFACE}

the Christian tradition, the fountain head of which is the Bible, especially the Gospels. The great value of the Bible is, therefore, in defining and fixing the Christian tradition ${ }^{1}$; and if the discussions in the following pages shall move any to examine carefully and open-mindedly the teachings of the Gospels in connection with the great problems of our time, then the author will be more than repaid for his labors.

So many friends have helped in the preparation of this book by their suggestions and criticisms that it is impossible for me to acknowledge my indebtedness to all of them. I feel, however, particularly indebted to Professor George A. Coe of Union Theological Seminary, whose suggestions and criticisms have been invaluable to me. Also I am indebted to Professor Herbert N. Shenton of Columbia University who has read large portions of the manuscript. These kind friends should not, however, be held responsible for anything in the book, as that responsibility is solely my own. I am also indebted to a number of my colleagues at the University of Missouri, especially to Professor A. F. Kuhlman of my department, who has helped me in correcting both the manuscript and the proofs.

UNIVERSITY OF MISSOURI,

Charles A. Ellwood. November 24, 1921.

1 For a full statement of the author's attitude toward the Bible, see pp. 145,152 and 153 . 



\section{CONTENTS}

CHAPTER

PAGE

I. The Religious Revolution • • • 1

- II. The Social Significance of Religion • 33 . III. The Social Significance of ChrisTIANITY . • . . . . . 70

IV. Our Semi-Pagan Civilization . • • 93

.V. Positive Christianity the Religion of Humanity

VI. Tine Essentials of a Social Religion • 161 VII. Religion and Family Life • • • 188 VIII. Religion and Economic Life • • . 210 IX. Religion and Political Life • • • 243 X. Religion and Social Pleasure • . 264 . XI. The Opportunity of the Church • 280 Appendix • • • • • • • 307 



\section{THE RECONSTRUCTION OF RELIGION}


"We have a rich harvest of science, a profusion of material facilities, a vast collection of the ideas and products of past ages. .... We need now only harmony, order, union; we need only to group into a whole these powers and gifts; the task before us is to discover some complete and balanced system of life; some common basis of belief; some object for the imperishable religious instincts and aspirations of mankind; some faith to bind the existence of man to the visible universe around him; some common social bond for thought, action and feeling."-Frederio Harrison, The Meaning of History, p. 75.

"I believe that before all things needful, beyond all else is true religion. This only can give wisdom, happiness, and goodness to men, and a nobler life to mankind. Nothing but this can sustain, guide, and satisfy all lives, control all characters, and unite all men."-Frederic Harrison, The Creed of a Layman, p. 37. 


\section{THE RECONSTRUCTION OF RELIGION}

\section{A SOCIOLOGICAL VIEW}

\section{CHAPTER I}

\section{THE RELIGIOUS REVOLUTION}

A CRIsIs confronts religion in the modern world. A New Reformation is necessary within the Christian Church, if it is to survive, besides which the Protestant Reformation will seem insignificant. ${ }^{1}$ Like all our other institutions, religion is in revolution. Either some new form of Christianity ${ }^{2}$ or sheer atheism will soon become dominant in the more advanced nations, with agnostic scientific positivism as a third possibility. A fourth possibility, of course, is that our whole civilization may revert to a lower level, and that older and cruder forms of religion may again appear and become common. But this could scarcely occur until the foundations of the higher forms of religion had become sapped; while for psycho-

'See Fitch, Can the Church Survive in the Changing Order?, especially pp. 69-79.

2 We shall use this term, unless qualified, to mean the religion of Jesus-surely its proper sense. When educated people discuss the merits of Buddhism, they usually mean the religion of Gautama Buddha, not the hodge-podge which goes by that name in various lands. So in a scientific discussion of religion, it is only fair to let Christianity be the name for the religion of Jesus rather than the clutter of historical beliefs which have at one time or another assumed that name. 
logical reasons (which we shall later discuss) any widespread dissemination and popular acceptance of an agnostic positivism is improbable. Practically, therefore, the alternatives before the modern world in a religious way would seem to be either radical irreligion or some more socialized and rationalized form of the religion of Jesus than has yet been attained. The final outcome of the religious revolution through which we are passing ${ }^{1}$ is not yet discernible; but its possibilities are, and it is time for thoughtful men to choose among these possibilities while they are still free to shape the future of religion.

The crisis in the religious world has been brought about by the failure of existing religion to adapt itself to the two outstanding facts in our civilization-science and democracy. The church must learn to adapt itself to these- two mighty forces which are building our civilization. Of these two, soiepce is the more outstanding and dominant. It is the foundation of our views of life and of the universe, as well as of our material progress, and so it has largely created the conditions which have favored the rise of modern democracy. Yet the maladjustment of religion with science remains pronounced. Often are we assured by some one in the name of science that science can find nothing in religion except superstition, error, or "the will-to-power" of some privileged class; while, on the other hand, the representatives of religion not infre-

${ }^{1}$ Says Professor E. G. Conklin (The Direction of Human Evolution, p. 244) : "To-day we are in the midst of a religious revolution, which is going on so quietly that many do not notice it, although it is a greater and more fundamental revolution than any since the early years of the Christian era." And, he asks: "Can Christianity become the religion of reason and science as well as of emotion and faith, and be made the power for individual and social progress which its founder intended?" The reader will note that the phrase "religious revolution" is used in this book like the phrase "industrial revolution," not to indicate a violent change, but a great transformation. The Protestant Reformation was a religious revolution in this sense. 
quently proclaim it outside of the field of science and re sent its scientific evaluation as a species of "sacrilege." Both attitudes have made difficult the attainment of rational religion; that is, a religion in accord with the established facts of human experience. ${ }^{1}$

But if religion is a vital element in civilization (as we hope to show), then the attainment of a rational, ethical religion is one of the greatest and most fundamental of our social needs, and nothing could be more short-sighted and stupid than an irrational attitude toward religion, whether on the part of its defenders or of its critics. In the reconstruction of our civilization which we now face, it is time that scientific thinkers and the representatives of religion join hands in seeking to promote the development of rational religion as the world's supreme need.

For we shall not be able to reconstruct our civilization without the reconstruction of religion; and the first thing to be aimed at in the reconstruction of religion is to make it rational. ${ }^{2}$ Science, as we have noted, is the outstanding and dominating fact in modern civilization. A religion which is "adapted to the requirements of modern life". must first of all be adjusted to modern science. A religion which is not in harmony with modern science cannot possibly remain the religion of the thinking class of the future. The hope for religion, as for our social life generally, must lie in following: reason, not in thwarting it.

1 Almost equally regrettable, because harmful to the true interests of religion, is the attitude of those religious people who resent all criticism of religious beliefs and institutions by scientific men, even when made with constructive intent. Constructive criticism should always be welcome, for it is the normal method by which institutions grow. See my Introduction to Social Psychology, p. 149f.

2 For a critical discussion of all that is implied in this word and for the presuppositions of the argument of this book, the reader cannot do better than to consult Professor Hobhouse's recent work, The Rational Good, especially Chapters I and III. 
This may be evident, but there are difficulties in the way. Strangely enough, the defenders as well as the critics of religion have often held that to make it rational would be to destroy it. Ever since Immanuel Kant wrote his treatise on Religion Within the Limits of Mere Reason, there has been continual controversy between those whom we may call the rationalists in religion and those who have stood for some form of irrationalism, whether traditionalism, mysticism, or some other. ${ }^{1}$ Without denying that there are necessary elements of tradition and mystery in all religion (even science has these), it would seem that this conflict is no longer unresolvable. Scarcely any one would be willing to acknowledge that his particular religious faith is unreasonable. Every one acknowledges, in one way or another, the supremacy of the human reason as the ultimate means of testing beliefs and actions. ${ }^{2}$ The whole world has become rationalistic in the sense that it acknowledges that the validity of everything must ultimately be tested through rational processes; ${ }^{8}$ and religion

1 The solution of the problem of the relations of religion and science proposed in this book is, in a sense, the opposite of that proposed by Kant. Kant claimed that the problems of religion could not be approached through science or ordinary rational knowledge, but that religious beliefs were necessary, rational, postulates of the moral life. Thus he created a dualism in intelligence.

2 Eren those persons, one may add, who use reason to refute reason or to show its limitations. For a statement of various anti-intellectual attitudes toward religion, see Hocking, The Meaning of God in Human Experience, Chap. 4. It may be well to state at the outset that no intellectualistic theory of religion is proposed in this book. All that is proposed is to bring religion within the purview of science.

- This statement is true only when we critically judge the implications of modern frrationalism. For a bricf cxposition of irrationalism in modern science itself, see Hobhouse, The Rational Good, Chap. I. Much of the prevalent irrationalism is due to misunderstanding the term "reason." "Much of the prejudice against reason," says Professor Hobhouse, "Is due to a misconception for which its friends are as much responsible as its enemles. By loth alike reason is often taken as a thing apart. On the side of knowledge it is dirorced from experience, on the side of conduct fram feellng. In both cases the 
can scarcely hope that the processes which men make use of in judging other affairs of life will not be applied to it also. A religion which will meet the needs of modern life must accordingly be not merely remotely in some possible harmony with science, but it must be directly indicated by science as a necessity for the development of "a humanity adjusted to the requirements of its existence."

It may seem sheer audacity to declare that rational religion is not merely reconcilable with science, but that developed and completed science is a foundation for rational religion. Here, of course, it is necessary to guard oneself against being misunderstood. Fragmentary science, a science which sees the universe merely in bits, and which fails to recognize the social and spiritual life of man as subject-matter for its understanding, will see nothing in religion. Of such science there is an abundance in the world at the present time; but it would be as unfair to judge science by it as it would be to judge democracy by the pitiful examples of it also to be found all too frequently in the modern world. A science which envisages the total of reality, which aims at accurate knowledge of everything which exists, including the total life of man, will surely neither leave religion out of account nor be found antagonistic to rational religion. When we assert that science logically leads to, and will become a support of, religion, we only mean, therefore, that accurate knowledge of the universe and of the total life of man will do this. The more we know of the universo and of man, the more we shall know of God.

dirorce is fatal to a true understanding" (p. 19). "The conception of reason," he says later, "is not one of a faculty prior to and apart from experience... It is the conception rather of a principle operative within experience the work of which is always partial and incomplete, ... the process by which understanding deepens, error is repeatedly eliminated, and truth constantly enlarged." (pp. 73-75) 
But some one may say that science is only a method; that it is not coextensive with the term "accurate knowledge"; and furthermore, that the accurate knowledge which we have or can get concerns such a small part of the universe or of human life that it cannot possibly have anything to do with religion; ${ }^{1}$ and that we must be content, therefore, to keep our science in one compartment of our mind and our religion in another. Science and religion have nothing to do with each other and should leave each other alone. The reply is that science is not merely a method; that it aims at accurate knowledge of everything which exists, including religion itself; and that while its work is far from complete, its trend, its general direction, is such that we are able to see, in part at least, which way we must go if we follow its lead. Science, indeed, is itself nothing but the rationalizing activity of the human mind brought to bear upon the tangible problems of life.) It may, and does, regard its work as incomplete, wherever the evidence needed for a judgment upon those problems is incomplete. Thus it hands over to philosophy the work of formulating rational inferences regarding ultimate problems. But modern philosophy aims more and more to become scientific; and religion, if it is to survive in a scientific and rationalizing world, must move along the same path. As a recent writer has well said: "If religion is nothing but the sub-

1 The arbitrary limitations put upon science both by its friends and by its critics at times, are as absurd as those put upon religion. Thus it is said that science is merely the method of measurement, or the tracing of casual mechanistic sequences; that it cannot take teleology into account, even though human purposes are a part of human experience, etc. The contrary assumption of this book is that the development of science can be limited only by human experience; that science is "a movement towards the knowledge of reality"; and that consequently everything within human experience may be brought to its tests. See Hobhouse, Development and Purpose, especially Part II, Chap. II. 
mission to mystery, it is doomed. If it is the trembling register of fear, transmuted maybe into softened keys but always fear,-if this is all there is in life that is religious, it is not enough to satisfy the rational intelligence. Yet that is what a theology based upon the irrational background of life demands. In short, there must be religion of the head as well as of the heart, if the head is getting control of the situation-or else religion will share the fate of the emotions in which it has been enthroned. It will be disbarred from directing the life of intelligence, both individual and social." 1

Another misunderstanding must here be guarded against; and that is that a rational religion will be a weakened, emasculated religion taking no account of man's impulses and emotions, but as arid and lifeless as the so-called "rationalism" of the eighteenth century. Indeed, a small group of people still exist who call themselves "rationalists" who display as their chief justification for this self-bestowed appellation a negative attitude towards all religion. ${ }^{2}$ Whether or not such persons are entitled to call themselves "rationalists" in any sense, it is evident that a religion adapted to the needs of human life cannot be a weak, colorless, largely negative intellectual belief, but it must enlist the whole nature of man. It must appeal to his impulses and emotions as well as to his most highly developed reason. A rational religion is one which can meet all of these tests. That, indeed, is the very mark and criterion of its rationality, that it is in harmony with the whole life of man; only in that life of man it finds the developed reason to be the final organ

${ }^{1}$ Shotwell, The Religious Revolution of Today, p. 154.

- One writer (Benn, The Mistory of Rationalism) has even gone so far as to define rationalism as "the mental habit of using reason for the destruction of religious beliefs." 
of adaptation, the highest and hence the ultimate guide. ${ }^{1}$ It would be an irrational science which would fail to take account of the whole nature of man, and which considered him merely as an abstract intellectual creature motivated and controlled by "pure reason"; so, too, it would be an equally irrational religion which would regard man as a creature of pure reason, or attempt so to appeal to him.

Even Kant did not mean that man is a thing of pure reason. ${ }^{2}$ What he meant rather was that religion so far as it was true and useful, like everything else true and useful, could be stated in rational terms; that is, that it could be rationalized, even though from its very nature it comprehended, in one sense, the whole life of man. Rational religion will still have its appeal to the emotions and to the impulses, as much as rational patriotism, or rational morality. It is the function of the reason, as the universal relating activity of mind, to harmonize everything in life, assigning to each factor its proper value in the whole process. ${ }^{3}$ It is because of this, indeed, that we trust the rationalizing mechanism in the human mind to be the final adaptive organ in the process

'Says Professor Fitch (op. cit. p. 36): "Rationalism means dependence upon one of man's faculties alone, the reasoning one"; and he rightly adds, "It is as partial and dangerous as dependence upon feeling alone." This, however, was eighteenth century rationalism; but neo-rationalism would make "experience as a whole the guide," only insisting that this should mean in final development, organized and verified experience-in other words, approaching and settling every question in a scientific attitude of mind. "To the truo rationalism," says Professor Hobhouse (Mind in Evolution), "the supreme reason is no dry pedant living apart and blighting the free spontaneous life of impulse, but the animating spirit that interpenetrates experience and gives to its otherwise scattered fragments new and harmonious meaning."

- Kant's famous definition of religion, "The perception of all of our duties as divine commands," implies, of course, that in both man and religion there is something other than the rational element.

- Compare Hobhouse: statement (The Rational Good, p. 75), "Reason is the principle of interconnection persistently applied." 
of human living. We need to recognize fully, the worth of other elements in human nature, but we must realize that in the complex world in which we live these other elements cannot furnish the ultimate test of our values. It is reason which must lead us upward and on in our struggle to get a human life more completely adapted to the complex requirements of its existence. But it is not the reason of the individual by itself which we thus trust to lead us on to higher and better things. It is rather that developing reason in the whole life of society which we call "science." The individual reason, we all see, is narrow and limited; but the possibilities of handing down and accumulating the tested product of the rational activities of many individual minds, that is, accurate knowledge, from generation to generation are unlimited; and thus reason is bound to perfect itself in the race, ${ }^{1}$ if not in the individual, provided of course that some great calamity does not interrupt its work. The modern faith in science is thus itself a faith in the rational and rests upon a secure foundation of knowledge.

${ }^{1}$ Compare Spaulding, The New Rationalism; also Hobhouse, The Rational Good, Chapter III, and Hobhouse, Development and Purpose, p. 249. There is little or no ground for Kidd (Social Evolution) and other irrationalists limiting the function of reason to individual adjustments on the basis of self-interest, and finding all altruistic actions to be due to a supra-rational force. On the contrary, there are good psychological grounds for saying that when rational processes thus function they are imperfect or perverted by unsocial habits or impulses (see my Sociology in Its Psychological Aspects, pp. 120 and 274 ). The accumulated effects of experience in social traditions and institutions, moreover, must be regarded as the work of reason; e. g., the development of the scientific tradition in society. Skepticism in regard to the work of reason and science, as of everything else, is of course possible. The reader will easily find abundant illustrations of the distrust of reason and science in modern literature and philosophy, but it may be pointed out that such distrust always ends, if not in mysticism, then in pessimism or reactionary traditionalism. No better refutation of such irrationalism will be found than that in Hobhouse's Development and Purpose, and, more briefly, in his recent work, The Rational Good, Chapters I, III and VIII. 
It may be objected that there is another element in religion which gives us a surer foundation of certainty than any rationalizing process either in the individual or in the race can do; and that is the element of "inspiration," or "intuition," as modern philosophers prefer to call it." Even if there is such an element, however, it is bound to work with and submit to the reason. This is shown by the fact that the reason has often undermined the religious and moral "intuitions," or "inspirations," of other ages. Not that these intuitions or inspirations did not have a value for the particular time and occasion when they were delivered, but like everything else in life they were bound to submit to the criticism of the reason, and as a consequence many in time have been rejected. Those that we still accept we accept only because thus far they have been found to be rational when tested by critical reasoning. There are axioms and postulates in religion and morality, in other words, just as in science; but like those of science they must submit to rational tests if they are to remain accepted. ${ }^{2}$ The critical method of science does not leave unexamined even its own postulates, much less can it leave those of morality and religion. In the one case, as in the other, we may rest assured that "the intuitions of common sense," however, will in the long run be seldom overthrown when they are well grounded in total human experience. The fundamentals of religion, like the fundamentals of life itself, are not

1 The most recent expression of this attitude is found in Bergson's works. A brief presentation of his point of view will be found in his Introduction to Metaphysics, translated by T. E. Hulme. While intuition is now generally recognized by psychologists as having a certain validity, there is no warrant in psychology for placing it above critical reasoning and scientifie method. Compare Coe, The P'sychology of Religion, p. 9.

2 On the place of intuitions and postulates within the rational, see Hobhouse, The Rational Good, pp. 64-72. 
going to be thrown out of the window by science in the name of reason, but rather will be tested by reason. If anything is finally rejected it will be because, being tested, it is found wanting. Thus a rational religion which shall be far stronger in its hold upon human belief in the social future, because resting upon adequate and secure foundations, is clearly possible.

Nevertheless, the struggle to secure a rational religion in the modern world has been accompanied by the most profound social disturbances. Men's beliefs, even in the things which were accepted as axiomatic by the past, have been undermined. The whole structure of values and standards by which civilization has been sustained from the stone age to the present has seemed at times about to crumble and give way. Our whole modern life has been largely during the last two decades a scene of confused and conflicting values, ideals, and standards. ${ }^{1}$ Now there can be no doubt that the main element disturbing the habits, standards, and beliefs of the past in the modern world has been science. The new knowledge which it has brought has often been difficult to assimilate with the old beliefs and standards. It has not only infinitely enlarged the world in which man lives, extending it even beyond the limits of his past imagination, but has even transformed the physical environment in which he lives. This transformation of the environment, or man's conquest and control over nature, has made his social life much more complex. ${ }^{2}$ By furnishing a much larger food supply, it has multiplied human populations many fold, and so multiplied and intensified social contacts between individuals. By inventing new means of controlling and harnessing

${ }^{1}$ See The Social Problem, Revised Edition, 1919, Chapter I.

2 Ibid., pp. 77-85. 
physical energies, it has made the world in which the civilized individual lives a world of machines. The invention of machines, moreover, has produced what is known as "great industry," and great industry demands such organization that the individual himself seems to be nothing but part of a vaster machine. New methods of transportation and of intercommunication made possible by these new mechanical inventions have brought about at the same time greater interdependence, contact, and intermingling of all the peoples of the world. The whole planet is now no larger than a good sized island was at the beginning of the nineteenth century. Race contacts and international contacts have vastly multiplied. Cultures $^{1}$ and civilizations so blend and overlap that it is beginning to become evident that one relatively uniform culture must finally dominate the world.

In the religious world these changes in science, in industry, and in the general social environment have produced what has been aptly termed "the religious revolution." Not only have old theological beliefs crumbled, but the theological way of looking at life and at things generally is seen to be of much less importance than former generations supposed. The entire edifice of speculative theology has, indéed, been undermined, and by many scientific thinkers it is assigned to the same rank as the mythologies of primitive and barbarous peoples. Because of the identification, moreover, in the popular mind of religion with theological beliefs, religion itself as a "control" over life has greatly suffered. Not only have religious beliefs and values changed, but they have been immensely weakened. Says an eminent English

1 The word "culture" is used in this book, as in sociology and anthropology generally, meaning civilization in the widest sense. In this sense all human societies, even savages, possess some degree of culture. For the stages of culture, sce Chapter III. 
social and philosophical thinker: "The influence of the Christian religion on daily life has decayed very rapidly throughout Europe during the last hundred years. Not only has the proportion of nominal believers declined, but even among those who believe the intensity of belief is enormously diminished."

The truth of this statement, even though it is made by one avowedly hostile to Christianity, can scarcely be doubted by any one who knows fully the facts. ${ }^{2}$ It would not be disturbing, however, if in the place of the traditional Christianity which has existed in Europe during the last hundred years some socially higher form of religion was manifestly emerging and becoming dominant; but instead we find manifest everywhere, as we shall see, a recrudescence of the ideas, values and standards of the religions which preceded Christianity in Europe, even in their cruder and more brutal forms. ${ }^{8}$

1 Bertrand Russell, Principles of Bocial Reconstruction, p. 168.

'In his well known investigation on The Belief in God and Immortality, Professor J. H. Leuba concludes from a study of the opinion. of nearly one thousand students in the leading American colleges that "Christianity, as a system of belief, has utterly broken down, and nothing definite, adequate and convincing has taken its place. Their beliefs, when they have any, are superficial and amateurish in the extreme." This confusion and uncertainty in religious beliefs is, of course, to be expected in an age of revolutionary religious changes. Many critics of Christlanity would interpret such phenomena as signs of its passing. Thus Edward Carpenter in Pagan and Christian Creeds (p. 257) says: "That Christianity can continue to hold the field of religion is neither probable nor desirable ... The hour of its Exodus has come." "Such critics usually mean by "Christianity" some form or forms of religion taught by the Christian Church rather than "the religion of Jesus," and usually have little or no idea of the social crolutionary significance of the latter as set forth in Chapter III.

- See Chapter IV. The recrudescence of pagan ethical and religious attitudes, discussed more fully as survivals in our civilization in Chapter IV, is pointed to here merely as evidence of the revolutionary changes which our ethics and religion are now undergoing-confusion and reversion to earlier forms always being characteristic of revolutionary periods. 
The confusion, doubt, and uncertainty which pervade our world of religious beliefs and values is not, then, an isolated phenomenon. It is only one manifestation of the general confusion which exists in the whole modern world as regards the values and standards of human living. In the new and complex social world in which we live the values and standards of simpler ages are often found totally unadapted to present conditions, and because so many have been found wanting, doubt and uncertainty have spread to all. Even the most fundamental beliefs, values, and standards by which men hitherto have lived have come to be questioned. ${ }^{1}$ All the institutions of the modern world may be said to be at the present time in the melting pot, being tested in the crucible of fiery. criticism.

Such confusion as we are now living in is to be expected in all ages of transition; for in the transition from one way of thinking to another, from one form of institution to another, there is always a period of confusion and uncertainty. ${ }^{2}$ No individual, to say nothing of a whole civilization, ever radically changes his habits without such a period. The danger in all such cases, however, is that confusion and uncertainty may last too long,

"Says Professor Hudson (The Truths We Live By, p. 21): "The standards of the home, even the criteria for the rearing of children, have broken down. The leisure occupations of youth, always symptomatic of any age, are not only unguidedly and frankly hedonistic, but across the borders of what was once considered decorous; not because of a new and liberalizing moral standard, as is sometimes pretended; but because of the lack of any. The popularity of certain recent dances, formerly forbidden even in the "red-light" districts, is typical. So is much of our periodical reading matter and any number of 'movie' plays, over the edge of the decadently erotic." However, after a careful discussion of the present conflict and confusion of ideals, Professor Hudson rightly concludes: "The contradictions of our own day may mean ... the advance toward a new moral order." See my book, The Social Problem, pp. 29-43 and 73-86.

'See Introduction to Social Psychology, pp. 163-164. 
and that instead of new and higher adjustments being made under the guidance of reason, human nature may fall back upon primitive and irrational adjustments. For adjustment upon the plane of animal impulse or reversion to old habits is always easier than adjustment upon a new and higher rational plane. To think out the problems of life requires effort, and when ennui overtakes the popular mind in such periods of confusion, it is easier to fall back upon mere impulse or mere tradition. Thus serious reversions may occur in the development of our general social life; ${ }^{1}$ and such reversions are an ever present danger in our religious and moral life as well as in other phases of our social life.

There is, however, no cause for despair in all this confusion, doubt and uncertainty regarding religious and other social values, provided we can get light upon the reconstruction in religion and in our social life generally which is needed to meet the requirements of modern life. A period of revolution and change gives opportunity for advance not less than retrogression. Whether we shall have advance or retrogression depends upon the rational guidance which can be given to social movements at such a time. It is foolish to expect that in such a crisis religion and morality can escape the criticism which is being applied to all other institutions. Their friends can best serve their interests not by seeking to shield them from criticism but by seeking to guide criticism into rational channels. Unless, however, the religious revolution (or readjustment) through which the civilized world is now passing has rational, scientific guidance, the chances are wholly upon the side of readjustment upon a much lower social and mental plane than that of the 2 Ibid., pp. 184-187. 
traditional theological Christianity which our modern world is leaving behind.

There is unfortunately abundant evidence ${ }^{1}$ just at present in the civilized world of reversion to a lower plane of moral and religious values than existed a generation ago. It is true that there have also been made throughout the civilized world during the last few decades many efforts to lift both religion and morality to a higher social and to a more rational plane. But in the face of the world-wide conflicts of the present it would be foolish for even the most optimistic to believe that such efforts have been generally successful; for the conflicts between the classes, nations, and races of the modern world are only indicative of the fact that as yet no values, adequate for a basis of harmonious human living together, have been generally accepted. We must candidly face such facts; and while there may be many grounds for encouragement, as the writer himself firmly believes, it is useless to deny or to gloss over the facts which seem to indicate partial social, moral, and religious retrogression. ${ }^{2}$ )

${ }^{1}$ A part of this evidence will be found in Chapter IV. The complexity of our civilization, of course, makes impossible any generaliza. tion which will apply to all sections of our population, and the statements made are meant to express only general trends. Leaders especially often advance while popular standards do not do so or revert.

2 The scientific student of society finds that periods of retrogression in certain lines of culture are not unusual in human history; indeed, that the very method of progress in the past at least has been by successive advances and retrogressions, just as the mind proceeds by the "trial and error" method. On the confusion, uncertainty and reversions which we are likely to find in periods of social transition, see my Introduction to Social Psychology, pp. 162-164.

Says one of the more penetrating popular religious writers: "Blind indeed are those who do not see the fact that a great change has come over men's thought on the subject of religion. ... We have broken with the old historical conception of religion in general and of Christianity in particular, and we have not, as yet, taken hold of the new conception. We are out of the old house and not yet in the 
It should be unnecessary to say that the scientific social thinker who is accustomed to the idea of progress is not disturbed by those specific changes in modern life which indicate a progressive rationalization of religion and morality. He raises the question of decadence only when he finds reversions toward forms which he knows belong to a lower rather than to a higher stage of social development. If, for example, he found the traditional Christianity of the past being replaced by a form of religion which was evidently more adapted to the scientific knowledge and to the general requirements of the social life of the present, he would not be disturbed by such a statement as the following, made by a recent English writer: "Certainly during the years immediately preceding the outbreak of the war there were signs that sympathy with the Neo-Pagan spirit was deepening and becoming more widespread. In literature and art, in journalism, in philosophy, and even in the Church there were solitary individuals and small groups of men and women who were beginning to make themselves heard. . . . The most potent element . . . was probably the increasing influence of Nietzsche."

Too much in our social life may easily be ascribed to the influence of an individual ; but individuals often symbolize social tendencies. If Nietzsche were not profoundly

new. Our state of mind is an unsettled state, our opinions being in the condition of the vines that have been torn from the wall to which they clung, without being given anything else to cling to.

"I am sure that the new wall is in process of building, and that in due time the vines now trailing the dust will find upon it proper support. In a word, the rational-that is to say true-interpretation of religion will come by and by, and when it does there will be an abundant supply of men ready and willing to proclaim its uplifting truths."

To this statement the author would heartily subscribe. 
symptomatic of his age and of the present day, ${ }^{1}$ if he were not a symbol, if he did not set the problem for us, it would be idle to mention him at all in our discussion. But from Machiavelli to Nietzsche there has been a constant succession of writers who have denied and derided the social ideals of Christianity. The attacks made upon theological Christianity left the social influence of the Church but little, if at all, weakened; for original Christianity, that is to say the teachings of Jesus, had had but little theology in it. The Church has often condemned men for their theological opinions; but Jesus never did. The profoundly significant thing in the religious revolution, then, has been not the attack upon theology, but the attack upon and the gradual undermining of Christian ethical ideals; and in this movement Nietzsche not only marks the culmination but symbolizes and embodies what we must undoubtedly regard as one of the strongest tendencies of modern civilization-the movement back toward pagan ideals. This is the opinion not only of a host of writers friendly to Christianity, but also of many of the avowed exponents of Neo-Paganism itself. For the purposes of our discussion, then, Nietzsche is merely. a symbol to define our problem.

If Nietzsche symbolizes so much in the spirit of our time, and especially the tendency to reversion to the pagan level, it will be well to present a few of his leading ideas in brief quotations, even though the literature of the present is crowded ad nauseam with these.

"I regard Christianity," says Nietzsche, "as the most fatal and seductive lie that has ever yet existed." 2 "Sexu-

1 Despite the large literature upon Nietzsche, there is little that treats of him as a social phenomenon, a product of our civilization. An approach to this is found in Figgis, The Will to Freedom.

${ }^{2}$ The Will to Poxer, translated hy A. M. Ludovici, p. 163. This is the best single book to present Nietzsche's ideas. 
ality, lust of dominion, the pleasure derived from appearance and deception, great and joyful gratitude to Life and its typical conditions ... these things are essential to all Paganism, and it has a good conscience on its side." 1 "Poverty, humility, chastity, are dangerous and slanderous ideals." 2 "Morality is a menagerie," concludes Nietzsche, "it assumes that iron bars may be more useful than freedom, even for the creature that it imprisons." 3

In one respect Nietzsche was, of course, not symbolical of his age, or at least of no increasing party in it; and that was in his hatred of democracy and his exaltation of the aristocratic ideal of life. "The maintenance of the military state," he says in a characteristic passage, "is the last means of adhering to the great tradition of the past, or, where it has been lost, to revive it. By means of it the superior or strong type of man is preserved, and all institutions and ideas which perpetuate enmity and order of rank in states, such as national feeling, protective tariffs, etc., may on that account seem justified." 4

It will not do to dismiss Nietzsche's ideas with the remark that he was mentally abnormal, because the enlightened egoism, brute force, class aggrandizement, and general glorification of the brute in man which he preached have been altogether too prevalent in our civilization to admit disposing of Nietzsche's creed in such a manner. Indeed, three centuries ago Machiavelli said very much the same things, and he, too, was symptomatic of the reversion toward pagan ideals in his day. If his teachings do not appear to have had the influence which Nietzsche's teachings appear to have at present, it is only

${ }^{1}$ Quoted by Figgis, op. cit., p. 277.

The Will to Power, p. 183.

8 Ibid., p. 348.

- Quoted by Figgis, op. cit., p. 282. 
because Nietzsche is more profoundly representative of certain tendencies of our age. Few in the English-speaking world even knew Nietzsche's name previous to the Great War; but that his practical followers even among English-speaking people have numbered millions, no one can doubt who has probed deeply into the spirit of our time, ${ }^{1}$ though of course few of his unconscious followers have had the courage of conviction or the logical consistency which Nietzsche had. Whatever his madness, he did the world the invaluable service of showing what the movement back toward pagan ideals logically means in its final development. We have quoted from him, then, because he sets the problem for us. The religious problem of our day, in other words, is not a problem in metaphysics or theology; it is a problem in the practical values of human living. This Nietzsche with characteristic insight clearly saw and emphasized.

Already two generations ago Comte foresaw some such issue, when he declared that theological Christianity was dying and that the first task of social science was to find adequate scientific supports for Christian morality. Christian morality, he feared, might disintegrate with the decay of Christian theology, with resulting calamity to civilization, unless science provided for the former a scientific basis. Only he failed to appreciate that there was little chance of preserving Christian morality without the world's acknowledging the leadership of Jesus.

Let us now turn, however, from the world of opinion to the world of action. There we find, if anything, even more tangible and startling proofs of the Renaissance of Paganism. ${ }^{2}$ The worst in pagan morals found constant

${ }^{1}$ See Chapter IV.

" For fuller definition of "paganism," "pagan ideals," see Chapter IV. 
and reiterated expression in the Great World War. ${ }^{1}$ The War itself was, indeed, at bottom nothing but the expression of the development of pagan tendencies in the modern world. These tendencies came to a head in modern Germany, and her ruthlessness in the War only foreshadows the "terror" which the religious revolution may bring to the whole world unless we succeed in establishing a socialized religion and morality.

While Germany undoubtedly led in paganizing the world, it would be foolish to fail to see that the same tendencies have been at work in a marked degree in every nation of Christendom. Machiavellian statecraft, making might and expansion the sole object of international politics, and the power of one class over another the chief end of domestic politics, has been increasingly manifest for the last three or four decades among Western nations. Behind this Machiavellian statecraft has been a ruthless and predatory organization of certain business interests that aimed only at enormous profits, either from the exploitation of natural resources within the nation, or of foreign markets.

In the private concerns of life reversion to lower levels of conduct has been not less in evidence. Marriage and the family life have become exploited by individuals simply for their own happiness and pleasure. Divorces have become increasingly common, ${ }^{2}$ venereal diseases have

${ }^{1}$ For elaboration, see Chapter IV.

2 Already by 1916 the official statistics showed that the divorce rate in the United States (one divorce to nine marriages) exceeded that of Japan, which previously had had the highest divorce rate of any great civilized nation. For fifty years the divorce rate has increased in the United States nearly three times as fast as population. The sociological significance of this movement is not generally appreciated. The family is not only the chief primary group, but it is the chief reator and bearer of primary moral ideals. The disintegration of the family is, therefore, necessarily accompanied by moral disintegration. 
doubled and trebled in the population, while free love, temporary marriages, and polygamy have found ardent advocates.

In the realm of practical moral and religious movements, the religious revolution has already expressed itself in striking phenomena. Religious and moral agnosticism have become common in the sophisticated circles of society. It has become fashionable in some of these circles, indeed, to believe in nothing except mere negations. But among the less critically minded, lower forms of religion and ethics already have begun to appear. We find revivals of polytheism, of oriental mysticism, of sun worship, and similar cults. ${ }^{1}$ It is becoming evident, indeed, that if rational religion does not dominate in our civilization, in the long run irrational religion is bound to do so. ${ }^{2}$ Nietzscheism itself may be regarded as but one of these irrational cults. It is scarcely necessary to mention. that one of the striking phenomena of the Great War was the tendency it revealed to revert to lower forms of religious beliefs and practises. Not only did the religion of fear tend to displace the religion of trust, and

See my Sociology and Modern Social Problems, 1919 edition, Chapters IV and VIII.

I In a recent editorial the editor of Nature (London), commenting on the "remarkable recrudescence" of belief in amulet.s, mascots, and other forms of magic in present society rightly characterizes these as antisocial reversions to a wholly primitive mode of thought. He adds: "To the sociologist this phase of modern credulity is of the greatest moment. Religion, with the attendant moral codes, has, on the whole, proved one of the strongest factors in the preservation of the social structure. . . . Should the place of (ethical) religion be taken by a reversion on any extended scale to a wholly primitive mode of thought, the prospect affords faint hope of social security and progress." Of course, the same remarks would apply equally well to any of the other retrogressive movements mentioned.

'Says Professor Hobhouse: "The history of our time shows that if men no longer believe in God, they will make themselves gods of power, of evolution, of the race, the Nation or the State" (Metaphysical Theory of the State, p. 234). 
the religion of hate the religion of love, but tendeneies were even in evidence to revert from true monotheism to "henotheism." 1 National deities were again invoked and found worshippers.

Many questions connected with the religious revolution might here be raised. In the next chapter we shall try to show that religion and morality are the most profoundly significant things in determining the character of our social life, and that therefore such phenomena as those we have just discussed are of the utmost social import. But before we attempt this it may be well to ask, whither are we going? What is to be the end of the religious revolution? Is it to end in the negation of religion and, possibly, of idealistie morality?

Before any one draws such a pessimistic conelusion it would be well to remember that while the dangers of serious reversion are great in any period of social transition and revolution, yet they are not insurmountable, and if met by rational intelligence they will probably be overcome and a higher stage of development ushered in. Human history, indeed, gives us every encouragement to believe that this will be the result in the present erisis, if the sensible and rationally-minded leaders in religion and ethics lay aside their minor differenees, close up their ranks, and unite in leading civilization to a higher phase of religion and morality. For the world has passed through many religious revolutions in the past, or at least, through many great religious changes, and there can be no doubt that hitherto the vast majority of them have been for the better. Neither pessimism nor foolish optimism

1 This word is used by students of religion to designate the nationalistic stage of religion preceding true monotheism. See next chapter. 
are warranted, then, in the present crisis in religion and ethics; but only determination on the part of religiously minded people, whether inside of or outside of churches, to meet the crisis with wisdom and rationality.

Religion is a thing which is evolving, developing, like everything else in the world. ${ }^{1}$ The type of religion which was suited to yesterday will not be suitable-for to-morrow; and yet the essence of religion remains the same, as we shall see, while it ascends to higher and higher forms. Like everything else in human culture it builds itself upon foundations laid in the past. There is no such thing in civilization as a new way of human living which is not rooted in the past. Progress consists rather in the invention or building up of new elements, institutions, or ways of living, through a selection and re-combination of old elements. But if the new is to work well there must be careful and rational selection of the old. We must be careful to see that nothing of real value for the present or the future is lost. This is the true policy of social conservation, and it applies in religion and ethics as well as in all other social matters. If we follow this pathway of "conservating" progress, we can never go far astray.

No less than seven distinct stages of religious evolution, of man's conception of the divine, according to anthropologists, may be found in the past; namely, manaism, animism, totemism, ancestor worship, polytheism, henotheism, and monotheism. ${ }^{2}$ Each stage has

${ }^{1}$ Says Professor Conklin (The Direction of Human Evolution, p. $175)$ : "The fact of the evolution of religion is held by some to destroy its value and significance, but one might as well hold that the development of the individual destroys the value or personality or that the evolution of man destroys his unique superiority over all other creatures."

"These are dealt with more fully in the next chapter (pp. $48 \mathrm{f}$.). They are mentioned here merely to give background to the present stage of the general discussion. 
meant a higher conception of the universal reality in which man lives, and moves, and has his being. It has meant, also, a higher conception on the part of man of his own life and destiny and of his relationship to his fellow men. Thus far each new stage in the development of religion has meant a new stage in civilization and vice versa. The question is, What is the next stage? Is it "atheism," as so many ${ }^{1}$ have said? Whither does the religious revolution now lead?

It hardly needs to be pointed out to the student of civilization that we have scarcely yet attained to a true monotheism; that we left henotheism behind but yesterday, and that still the peoples of the world are prone to relapse into it. It ought, also, to be unnecessary to point out that monotheism itself has many stages. "Deism," for example, the idea that God is a sort of super-engineer who made the universe like a great machine, was a favorite form of monotheism among those intellectualists of the eighteenth century who clung to some sort of attenuated religious belief. Curiously enough, we may remark in passing, it is the sort of religious belief which is commonly ascribed to intelligent religious people by thase who would reject altogether the idea of God. And it must be acknowledged that deism, as well as henotheism, still abounds in the religious life not only of so-called Christian peoples, but even of members of Christian churches.

1 So Guyau in his Non-Religion of the Future. So also Miss Jane Harrison, author of several brilliant studies on the social origin and development of religion. So Eugenio Rignano, editor of the international scientific review, Scientia, and many others of many schools of thought. In the study referred to above, Professor Leuba found agnosticism and atheism very prevalent among American men of science. The conventional attitude of some scientific men is typically expressed by Sellars, who says (The Next Step in Religion, p. 217): "The truth is that mankind is outgrowing theism in a gentle and steady way until it ceases to have any clear meaning." 
It would be strange, indeed, if, in accordance with the principles which we have just laid down, we should find civilization transcending monotheism before it had fairly attained to it. The appearances are rather those of reversion to a lower stage than of evolution into a higher stage. The monotheistic stage of religious evolution, we have every reason to believe when we carefully examine the facts, has only just begun. Perhaps humanity may never attain fully to it; but if not, it will surely fall back to a lower form of religion. The religious revolution which we are now undergoing, if it does not fail and lead to a reversion, concerns the transition from theological to ethical monotheism, from a metaphysical to a social and scientific conception of religion.

Monotheism is not outgrown, for rationally understood, it can never be outgrown; we have not yet grown into it. We need a more social form of it; but we cannot escape the necessity for faith that the system of things is not alien to ourselves. If man is to have a vital, social religion he cannot believe that the universe is a "fool's house" which will bring to naught his highest endeavors. He must be able to face the universal reality of which he is a part with confidence that it is on the side of his highest endeavors. It is a part of his positive scientific knowledge that all that he is, all that he values, all that is highest and best in himself, has come from that one universal reality. ${ }^{1}$ It would be irrational if he did not believe that he could put his trust in the ascending energy of the universe which has created him and made possible his works. No; man will never cease to need a positive, constructive, trustful attitude toward the universe and the whole system of things. ${ }^{2}$ He must have confidence in his

1 See Chapter V, pp. 134-140.

See Chapter II, pp. 59-64. 
world, if he is not to despair. He must believe in the possibilitics and the value of life if his energies are to be fully released ${ }^{1}$ - if he is to function efficiently as a member of society, to the point, perhaps, of complete selfsacrifice. (He must be able, in other words, to confront the issues of life and death with a supreme faith; but to do this he must project his social and personal values into the universal reality itself. ?

Even the most primitive forms of religion did this for the most primitive men. Their religion braced their vital feeling, gave them confidence in themselves and in their world. The savage of to-day tells us that his religion, or, as in our superiority we would say, his superstition, makes him feel good, glad, gives him second sight, strength, success in war, and in all undertakings generally. More than this could scarcely be said, oftentimes, for the religion of even the most highly civilized individual.

In one great respect, however, apart from the content of theological belief, the religion of primitive man apparently differed from the religion of the modern man. The religion of primitive man apparently dominated his whole life, his government, his social organization, his family and sex life, his education, and even his foodgetting. ${ }^{2}$ This we know remained so even in mediaeral Europe; and it has often been pointed out that one great characteristic of modern society is the complete divorcement of one social interest after another from religion. Thus industry, politics, education, science, family life, and

${ }^{1}$ Says Professor Hobhouse: "If we believe the whole course of human evolution to be without significance... we shall place a lower estimate on all that makes for the control of natural conditions by the human mind, and a high one on all that leads to resignation and submission." (The Rational Good, p. 232.)

2 For elaboration, consult the work of Durkheim, The Elementary Forms of the Religious Life, especially Chapters I-IV of Book II. 
even morality itself, are said to have successively divorced themselves from their setting of religious feeling.

In so far as this is a wholesome movement it may be questioned, however, whether the separation is not more formal than real. An industry, politics, education, science, family life, morality, which are absolutely divorced from religious feeling and values, must become in time intolerable. The social life is such a unity that its values, as we shall try to show, must all be suffused with religious feeling if they are to come to the individual with the fullest sanction. The divorcement of politics, government, and the state from religion, for example, is not a divorcement which we need to fear, provided the individual citizen carries again his religious attitude back into these practical activities; but a government which is in no degree controlled by religious values would soon cease to be a government in accord with the conditions of man's life. The so-called secularization of many activities, therefore, only means that these activities have been divorced from the formal control of ecclesiastical organization.

So far from such secularization being opposed to the real interests of religion, those who believe in free or democratic society see in this movement only opportunity for the vital expansion of religion. The release of these great human interests from formal ecclesiastical control gives opportunity, in other words, for vital religion, as it expresses itself through the conscience of the individual, to pervade and truly moralize these activities. To take another example, it has not been found that charity has lost any of its religious appeal or value through its being conducted by secular organizations or by branches of the state. On the contrary, by this very method the values of rational humanitarian religion have oftentimes been impressed more deeply upon the community as a whole. 
Ecclesiastical control must not be confused with control by spiritual religion. Even religion itself has profited by escaping from a too formal ecclesiastical control.

Still it would be foolish to overlook the fact that this secularization of one phase of our social life after another, if not accompanied by a deepening and broadening of the religious life of the individual, is fraught with many dangers. Thus we may easily get through such separation purely official and brutalized charity, a paganized, Machiavellian politics,-and a profits-at-any-price industry. Thus it comes about that the modern man with the immense complexity and specialization of his activities needs religion to safeguard his social life, if anything, even more than did primitive man. He needs it because he lives in a more complex, specialized world in which the difficulties of adjustment are greater. He needs it, also, because of his higher intellectual development which makes it more necessary for him to see a meaning in things beyond mere appearances if he is to adjust himself successfully to them. He needs it, finally, because stronger and more universal good will are necessary as social interdependence in a world-wide social life develops. As Comte said, then, man must become ever more religious, if he is to preserve that harmony of the inner with the outer which gives an abounding and satisfying life, whether in the group or in the individual.

But there is no argument, some may say, for the truth of religion in the fact that man needs religion. If by this is meant that the truth of any particular religious belief is not demonstrated by its social utility, that we would admit. It is not our purpose to discuss in this book the question of the metaphysical truth of specific religious beliefs, or even of the religious view of life in general. It 
is rather our purpose to point out the personal and social value of religion. In both science and practical life, however, we do judge the truth of propositions largely by the way they work out in practice-by their practical value. If we find that we cannot act on a proposition-that it will not work in practice-a presumption is established against its truth. Science, then, no less than religion is positive in its attitude toward experience. It does not proceed wholly by doubt, but affirms to be true what is tested by experience. Faith in the world of human experience, when taken as a whole and its errors allowed to cancel one another, is the supreme faith of science. Science rests upon this faith.

It is even so with sane religion. It, too, builds itself up out of the experience of life. If it affirms to be true certain beliefs and values, it is because it finds these to be justified by their works in the lives of men and in the whole structure of human society. The chief difference is in their history, that science has kept the open mind and has revised its appraisals of truth as experience has widened; while religion, becoming enmeshed in traditionalism, has too often refused to do this; it has too often remained static while society has been evolving. It has too often failed to keep the open mind.

But the religious revolution has now given religion the opportunity to become a dynamic rather than a static thing -to become "experimental," as it were; at least, to base itself upon the experience and needs of men in a present world. Thus between positive, constructive science and rational, constructive religion opposition should lessen. When social science becomes fully positive and constructive, it will indeed lead to rational social religion. The 
religious revolution need not, then, end in chaos and irreligion. It can and should end, if guided by intelligence, in a new era of rational religious faith. ${ }^{1}$

The great English painter, Watts, symbolized the faith, or rather the lack of faith, of the nineteenth century in his picture of Hope seated blindfolded upon the earth. But such a view of man's relation to the universal reality can bardly be taken as the final verdict of the rational mind. The absolute agnosticism and scepticism of the nineteenth century can scarcely be regarded as more than an abnormal mental attitude brought about by the confusion and uncertainty of a transitional era in religious beliefs. The ages of faith are not past, as we are often told; for faith is of the very essence of normal human life. The ages of irrational faith, we may hope, are past or passing; but the age of a rational and understanding faith is still ahead. We need the maximum of faith, not the minimum; but it must be a faith built upon facts. To reach such faith, we cannot turn our backs on knowledge, science, and revert again to mysticism. We must not fear intelligence. Our safety must consist in following it in building up, on the facts of life, a reasonable faith.

Says Professor Smith: "Beneath the stirrings and seethings of modern unrest, one discerns dimly the outlines of a religion which shall trust in the larger future instead of being bound literally to the past; which shall glory in the capacity of man to use God's resources to remake this world instead of inculcating a passive dependence on supernatural forces which lie out of man's reach; which shall develop scientific control into a mighty instrument

${ }^{1}$ Professor G. B. Smith is undoubtedly right in his contention (in his Social Idealism and the Changing Theology) that the world revealed by modern science is richer in possibilities of reasonable religious faith than the old supernatural world ever was. 
for the welfare of man instead of uttering warnings against the 'dangers' of scientific theories." 1

To sketch the outlines of such a religion, will be the task of the succeeding chapters.

${ }^{1}$ Social Idealism and the Changing Theology, p. 154. 


\section{CHAPTER II}

\section{THE SOCIAL SIGNIFICANCE OF RELIGION}

"Moralities and religions," said Nietzsche with characteristic insight, "are the principal means by which one can modify men into whatever one likes," provided, he added, that one is given time enough in which to do it. Yet nothing is perhaps more openly questioned to-day than the social power of religion. It is not our purpose to go fully into the psychology and sociology of religion, but [we must know something about the real nature of religion before we can understand its significance for the social life of man. This is the first thing necessary in considering the reconstruction of religion.

No one can doubt the power of religion in exceptional individual cases. St. Simeon Stylites lived at the top of a sixty foot pillar for thirty years without descending. The Hindu fakir holds his fist closed until the nails of his fingers grow through the back of his hand. Both these feats would seem incredible were they not well-authenticated facts; ${ }^{1}$ and indeed they could only be possible through religious fanaticism. The power of "fixed ideas" is a familiar fact of abnormal psychology. The "religious psychosis," as we might call it, has produced more mira-

1 The scientific facts for the interpretation of religion are, of course, as broad as human history. The literature of anthropology especially abounds in them. Perhaps the best collection of scientific material on religion is to be found in the monumental Hastings: Encyclopedia of Religion and Ethics, though the articles are of unequal value. See especially the articles on "Religion," "Animism," "Ancestor Worship," etc. Good bibliographies accompany each article. 


\section{THE RECONSTRUCTION OF RELIGION}

cles in human behavior than even the most enthusiastic advocate of religion has ever given it credit for. ${ }^{1}$ Not only have, by means of it, drunkards and criminals been reformed, prostitutes been led to lead a pure life, sinners in general made to repent, the sick made well, but the character of whole communities has been radically altered, even transformed, in the course of a few years. Such facts as these are not open to even scientific doubt, because they are checked up by overwhelming evidence on the one hand, and by the general principles of normal and abnormal psychology on the other hand.

Indeed, when we examine the matter, we find that religion has entered into the warp and woof of every civilization that the world has known. Sociology and anthropology show that this was not due to accident. What makes civilization is the mass of habits and traditions handed down with constant accumulations from generation to generation. But these habits and traditions cannot be thus passed on in human society without strong social sanctions attached to them. They are passed on, in other words, as customs, as traditional beliefs, values, and standards; in brief, as "mores." Now the mores of a people are all-powerful, but they are such only because they are embedded in religious sanctions. ${ }^{2}$ They begin

${ }^{1}$ Perhaps the best easily accessible collection of facts on the effect of religion on individual behavior is to be found in James's Varieties of Religious Experience, Lectures IV to XV inclusive.

'Durkheim's view (set forth in his Elementary Forms of the Religious Life) that primitive religion is the original matrix out of which have developed government, law, morality, philosophy, science, art, etc., is, of course, correct if we enlarge our conception of religion so that it means "the mores regarded as sacred." More narrowly, however, religion is a peculiar sanction given to the mores. For exposition of the sociology of the mores, see Sumner's classical work, Folkways: A Study of the Sociological Importance of Usages, Manners, Customs, Mores and Morals, especially Chapters I and II. 
to crumble and disintegrate as soon as the particular religious belief or sanction which accompanied them passes away. But with them crumbles and disintegrates the civilization of which they were a part. We have no record of a civilization which long endured which did not have this religious setting for its mores; nor of any which endured long after this setting was dissolved. ${ }^{1}$ The full reasons for this will become evident as we proceed. Our argument, however, will be seen not to rest upon the uncertain foundations of an historical induction, but rather upon fundamental laws of human nature and human society.

But, it may be said, the very illustrations just used show that religion is as frequently a power for evil as for good; or even that it is reactionary, and belongs to the irrational in human life. That it has been very frequently in the past a power for evil and for unreason, no sane student of religion or of human society would deny. Our only contention is that religion is a real power in human life, and one that cannot be dispensed with in the more complex stages of social evolution, even though it may be made to serve the evil as well as the good. By the same token that it may become a power for evil it may be made a power for good. All human history, in one sense, indeed, has been a search for a rational and social religion. Very early even in primitive ages those religious beliefs and practices which did not meet with the approbation of the community as a whole were outlawed and branded as "black magic." 2 So to-day we still brand as magic or

1 Hubbard in The Fate of Empires, Part II, assembles some of the evidence.

'See Marett: The Threshold of Religion, especially Chapter III; also his Anthropology, pp. 209-212. The general view of magic now held by a majority of anthropologists is that it sprang originally from the same fundamental processes in the primitive mind as religion. "The two fundamental concepts underlying both magic and religion are those of spirit and power." But magic and religion early 
superstition forms of religion which are manifestly antagonistic to the welfare of the particular community which passes judgment upon them. Religion in the strictest sense, as sociologically distinguished from magic and superstition, has always been beliefs and practices which the community approves. ${ }^{1}$ The struggle for a rational and social religion in our new world of science and of complex social relations is still essentially to-day what it has been in the past: it is a struggle to find a religion adapted to the requirements of present life.

But, again, it may be said that while religion has unquestionably been a power in the past social life of man, it is a dangerous power, seeing that it may work for the evil as well as the good, for reaction as well as for progress; and so is one which civilization cannot too soon get rid of. We no longer need "the religious psychosis," with its tendencies toward fanaticism or "fixed ideas" in our present humanitarian civilization. We especially no longer need it if our social life is to become rationalized, because it is the antithesis of reason. ${ }^{2}$ Statements like these, which we hear so frequently to-day, show a strange blindness to the actual facts of life, and remind one of that narrow "rationalism" of the eighteenth century which made man so entirely an abstract intellectual creature. Men still need help in life as much as in the ages gone

differentiated, magic becoming mechanical, impersonal, individualistic, while religion became spiritual, institutional, and congregational or collective.

${ }^{1}$ For a different view of magic see Leuba, A Psychological Study of Religion, Part II, especially Chapter IX.

- Compare, e.g., Bury's statement (History of Freedom of Thought, p. 229): "Religion is gradually becoming less indispensable. The further we go back in the past, the more valuable is religion as an element in civilization; as we advance, it retreats more and more into the background, to be replaced by science." For full criticism of this view, see pages 59-64 of this book. 
by. They do not and cannot live by reason alone, as we have already pointed out, but need some sort of faith in unseen powers, which we term "religion." The end of all religion is in social and personal salvation, in help over the difficulties and redemption from the evils of life. Like the mind itself, religion exists to meet the needs of life, and it is essentially an adaptive device of life; like reason, it exists in particular to meet the needs of life in very complex situations, in "crises," where the lower processes of body and mind are inadequate to cope with the situation. ${ }^{1}$ Exactly how it does this we shall see later. It will suffice now to point out that religion braces vital feeling, that it taps new levels of energy, and gives one thus strength, as we have seen, to perform deeds far beyond what are commonly regarded as normal human powers.

Now, so far as we can see, the time will never come when man will not have need of religion to release fully his energies, to brace his vital feeling, and to help him face the issues of life and death with confidence in himself and in his world. The dream which the hedonistic philosophers of the nineteenth century had of a "pleasure economy," in which there would be no need of the help which religion can give, because the difficulties and evils of life would be all overcome, has been rudely shattered. Not only has the World War shown that there is as much need of faith, loyalty, and self-derotion in the world as

1 That religion is wholly a social matter, purely a social product, as Durkheim apparently claims (in his Elementary Forms of the Religious Life), is a theory which will not bear close scientific scrutiny. On the contrary, like reason, religion has both individual and social roots and manifestations. A scientific view of religion must be found in a synthesis of Durkheim's sociological view and the psychological view, as set forth for example in James's Varieties of Religious Experience. For a criticism of Durkheim's view see Webb's Group Theories of Religion and the Individual, especially Chapters I-IV. 


\section{THE RECONSTRUCTION OF RELIGION}

ever, but a deeper understanding of the nature of the social life itself has revealed that, whether mankind is at peace or at war, this will always be so.

The nature of our social life, in other words, is such that if progress is to continue it demands constantly the service and sacrifice of individuals for the good of humanity. ${ }^{1}$ Each generation builds, as we have seen, upon the work of previous generations, and it is only through a policy of social conservation and of productive, efficient social service that civilization can be preserved and continually advanced. In each new generation the increasing complexity of the social life will call for heroism, self-devotion, and self-sacrifice for the good of humanity as in previous generations. Crises in life will not cease through human progress, nor will man come to need less the power of self-sacrifice. The world will never cease to need, in other words, clean, high-minded, self-devoted, self-sacrificing human living. The "soft" view of life, which was so popular in the ease-loving and self-indulgent pre-war days, has proved itself to be an unworkable view. The hedonistic utopia of a "pleasure economy" just ahead, in which no one would have to work harder, or behave better, than he wanted to, is seen to be a chimera. Men will always need for efficient, worthwhile human living, full command of their adaptive powers; and highest among these, standing side by side, as it were, yet often in these later days made strangely to antagonize each other, are religion and reason.

For what is religion? Why do we compare it as an adaptive process in the human mind to reasoning itself?

"See Novicow, Mechanism and Limits of Human Association (translation in American Journal of Sociology, November, 1917); also The Social Problem, 1919 cdition, pp. 273-280, and Introduction to Social Psychology, pp. 323-328. 
Let us see what religion does, and then we shall perhaps in part understand it. But let us first distinguish religion from theology on the one hand and ecclesiastical organization on the other. Theologies are products of religion in interaction with man's reason and imagination, but they are not themselves religion. Theologies as intellectual attempts at the interpretation of religion, appear and disappear; but religion remains. Religions have often existed without any well defined theological beliefs, though at other stages of the evolution of religion theological creeds may be the chief thing emphasized. While religions always imply metaphysical or theological beliefs of some sort, no specific theological belief is an essential part of religion. ${ }^{1}$ While religion affirms and universalizes personal and social values, it does so in a practical sense without necessarily developing them into theological or metaphysical dogmas.

Neither must religion be confused with ecclesiastical organization, that is, with the church and its ritual. The church is the organized embodiment, the institutional expression, of religious life. It is probably necessary to the social expression of religion, but it is not itself religion. Thus the Christian church, which we ordinarily call historical Christianity, must not be confused with Christianity itself. $j$ But if religion is neither theology nor ecclesiastical organization, what is religion apart from these? And what does it do apart from the creating of theologies and ecclesiastical systems?

In the first place, religion projects the essential values of human personality and of human society into the universe as a whole. It inevitably arises as soon as man tries

${ }^{1}$ For elaboration and qualification, see pages 45 and 46 and also Chapter V.

4. Clunst is Unuternty 
to take a valuing attitude toward his universe, no matter how small and mean that universe may appear to him. Like all the distinctive things in human social and mental life, it, of course, rests upon the higher intellectual powers of man. Man is the only religious animal, because through his powers of abstract thought and reasoning, he alone is self-conscious in the full sense of that term. Hence he alone is able to project his values into the universe and finds necessity of so doing. Given, in other words, the intellectual powers of man, the mind at once seeks to universalize its values as well as its ideas. Just as rationalizing processes give man a world of universal ideas, so religious processes give man a world of universal values. The religious processes are, indeed, nothing but the rationalizing processes at work upon man's impulses and emotions rather than upon his percepts. What the reason does for ideas, religion does, then, for the feelings. It universalizes ${ }^{1}$ them; and in universalizing them, it brings them into harmony with the whole of reality. For the mind to refuse thus to universalize its values is, in a sense, very much like the mind refusing to universalize its intellectual conceptions. There has always been, indeed, then, a close relation between irreligion and intellectual agnosticism, as all the world has long since observed.

We are now prepared to see more exactly what religion is in psychological terms. It is primarily a valuing attitude, universalizing the will and the emotions ${ }^{2}$ rather than

"So also it "socializes" them. The process of "universalization" of course includes the process of "socialization," only the whole of reality, including the community of human beings, becomes the reality to which adjustment is made. Why the universe as well as humanity must always be included in religious valuations is set forth on page 46 and also in Chapter $\mathrm{V}$.

This idea, that the psychological function of religion is to universalize the will and the emotions, is, of course, a very old one, 
the ideas of man. It thus harmonizes man, on the side of will and emotion, with his world. Hence, it is the foe of pessimism and despair. "It encourages hope, and gives confidence in the battle of life, to the savage as well as to the civilized man. It does so, as we have said, because it braces vital feeling; and psychologists tell us that the reason why it braces vital feeling is because it is an adaptive process in which all of the lower centers of life are brought to reinforce the higher centers. The universalization of values means, in other words, in psycho-physical terms, that the lower nerve centers pour their energies into the higher nerve centers, thus harmonizing and bringing to a maximum of vital efficiency life on its inner side. It is thus that religion taps new levels of energy, for meeting the crises of life, while at the same time it brings about a deeper harmony between the inner and the outer.

When we thus understand religion scientifically we see that it is as natural to man, and almost as necessary, as sleeping, eating, or breathing. But we must qualify this statement by saying that religion is essentially a social rather than an individual matter. Like language it is not so much necessary for the life of the individual as for the life of society. This is because the values with which it deals, which it projects and universalizes, are not simply personal values; they are social values. They are values in which an individual participates because he is a member of a group. They are values, in other words, which have been built up through the common life

going back even to Greek and Hindu philosophy, but it is rarely found clearly stated. That the valuing attitude is the root of all religion is now one of the commonplaces of religious psychology. Sellars (The Next Step in Religion, p. 7) even goes so far as to define religion simply as "loyalty to the values of life." 
of a group and transmitted by tradition from generation to generation, because they have to do with the life of the group. Values and feelings have more need to be universalized on the side of the social environment than on the side of the physical environment. It is one's human world to which one has to adapt himself first of all; and this adaptation is effected largely through the feelings or emotions. Then, again, the life of the group itself, sociology shows, is a unity. In confronting its environment and the many foes which are often found there, the group must have unity of feeling, of values, if it is to have unity of action, among its members. The group as a whole needs not only such inner harmony on the side of feeling, but it must command the full energy, the unfailing devotion, of all of its members. Its values, its emphasis upon the meaning of life, of service, and of sacrifice, must be brought to the individual in the intensest way, with that absolute sanction which religion gives, if it is to command that self-effacing devotion of its members in times of crisis. The universalization of feeling and will which religion effects is necessarily therefore a universalization which includes first of all the common life which the individual shares with his fellows. In other words, it is a "socialization" of feeling and will." [The second thing, then, which religion does is to act as an agency of social control, that is, of the group controlling the life of the individual, for what is believed

${ }^{1}$ No writer has worked out more clearly the interrelation of religion and social life than Professor Ames in his Psychology of Religious Experience. See especially Parts II and IV. His view that religion is "the consciousness of the highest social values" (p. VII), is one of the cornerstones of the sociology of religion. See also Miss Harrison's Themis: A Study of the Social Origins of Greek Religion, especially pp. 482-492. "Religion," says Miss Harrison, "sums and embodies what we feel together, what we eare for together, what we imagine together." 
to be the good of the larger life of the group. Very early, as we have seen, any beliefs and practices which gave expression to personal feelings or values of which the group did not approve were branded as "black magic" or baleful superstitions; and if this had not been done it is evident that the unity of the life of the group might have become seriously impaired. Thus the almost necessarily social character of religion stands revealed. We cannot have such a thing as purely personal or individual religion which is not at the same time social. For we live a social life and the welfare of the group is, after all, the chief matter of concern.

It is evident that this function of religion as a means of social control over the individual needs to increase rather than decrease as social evolution advances. For social life becomes more complex with each succeeding stage of upward development, and groups have more need of commanding the unfailing devotion of their members if they are to maintain their unity and efficiency as groups. More and more, therefore, religion in its evolution has come to emphasize the self-effacing devotion of the individual to the group in times of crisis. And as the complexity of social life increases, the crises in which the group must ask the unfailing service and devotion of its members also increase. Thus religion in its upward evolution becomes increasingly social, until it finally comes to throw supreme emphasis upon the life of service and of self-sacrifice for the sake of service; and as the group expands from the clan and the tribe to humanity, religion becomes less tribal and more humanitarian, until the supreme object of the devotion which it inculcates must manifestly be the whole of humanity.

Looked at from the point of view of the individual, in 


\section{4 THE RECONSTRUCTION OF RELIGION}

the third place, then, religion means the consecration of individual life, at first for clan and tribal ends, but finally for humanitarian ends. ${ }^{1}$ This consecration, or making "sacred," of life conserves the powers and energies of the individual for social uses. It again unifies the group and makes it efficient in confronting every situation. We do not mean, of course, that it unerringly does so, because the ends to which the individual may be asked to consecrate his life may be mistaken ends. The values which are socially sanctioned may not be the highest values; they may be false altogether. Nevertheless, by this consecration of life on the part of the individual to the ends or values of which the group approves, such efficiency as is possible for the group is attained. As the social life increases in complexity and expands from the clan and the tribe to humanity, it is evident that no less consecration of life on the part of the individual is demanded, but rather more. And we may so far anticipate our conclusion as to point out that when the group becomes humanity, and social values become scientifically determined, the consecration of individual life which religion necessarily means may be more cheerfully given by the individual; for he will have the satisfaction of knowing that such consecration is for the highest purposes. Thus becomes evident, too, our meaning when we say that the individual must become increasingly religious if he is to become increasingly social." Comte, as we have already seen, perceived this truth, though for

1 "The essence of religion," says Professor Cooley, "is the expansion of the soul into the sense of a Greater Life; and the way to this is through that social expansion which is of the same nature. (One who has developed a spirit of loyalty, service and sacrifice toward a social group has only to transform this to a larger conception in order to have a religious spirit." (Bocial Process, p. 75.) 
various reasons it has escaped the perception of many later sociologists.

A fourth phase of religion stands revealed as we come to understand what religion does. Religion, we have said, emphasizes values; it universalizes them and brings them to the mind of the individual in the intensest way. But the values which it has come to sanction are social values, values which pertain to the larger life, and finally to the life of all humanity. Now these mental and social values, with which religion deals, men call "spiritual."1 It is something which emphasizes, as we may say, spiritual values, that is, the values connected especially with the personal and social life. It projects these values, as we have seen, into the universal reality. It gives man a social and moral conception of the universe, rather than a merely mechanical one as a theatre of the play of blind, purposeless forces. While religion is not primarily animistic philosophy, as has often been said, nevertheless it does project mind, spirit, life, into all things. ${ }^{2}$ Even the most primitive religion did this; for in "primitive dynamism" there was a feeling of the psychic, in such concepts as mana or manitou. They were closely connected with persons and proceeded from persons, or things which were viewed in an essentially personal way. Religion, therefore, is a belief in the reality of spiritual values, ${ }^{3}$ and projects them, as we have said, into the whole

${ }^{1}$ It will be observed that we use this word in the broad or philosophical sense, as practically synonymous with "psychic," not in the narrow sense of "pertaining to spirits."

"Using "animism" in this broad sense (for the technical meaning of the term, see page 50), Carpenter very rightly says (Pagan and Christian Creeds, p. 260): "Animism is a perfectly sensible, logical and necessary attitude of the human mind." Compare McDougall, Body and Mind.

This again is a very old view of religion, reflected imperfectly in Tylor's celebrated minimum definition of religion, "Belief in spiritual 
universe. All religion-even so-called atheistic religions ${ }^{1}$-emphasizes the spiritual, believes in its dominance, and looks to its ultimate triumph. Materialistic and mechanistic philosophies, therefore, at least those - cruder forms which would deny altogether or explain away the reality of the spiritual element, are hostile to religion. They take a negative attitude toward the spiritual element in the universe and in human life, and therefore destroy the rational basis for that projection into universal reality of personal and social values which constitutes the essence of religion. Religion from its very nature cannot negate life or mind; it cannot take a negative attitude toward the universe. Its attitude is an attitude of faith, courage and confidence. ${ }^{2}$ It emphasizes, therefore, the reality of spiritual things; it is built up through belief in the reality of spiritual life. Mere animistic philosophy, to be sure, it is not; for it is always primarily a valuing attitude. But it is an affirmation of the reality of the spiritual, the mental, the social; and only in a few cases has it denied the reality of the material and the physical.

Thus we see that religion, springing as it does from the whole of human nature and the whole social life of man,

beings," and implied in Eucken's works, especially in his Christianity and the New Idealism, Chapter I. Leuba (A Psychological Study of Religion, p. 52) is undoubtedly right in contending that religion presupposes belief in personal or non-personal psychic powers.

'For example, Buddhism, Jainism, and Comte's Positivism. All these religions manifestly emphasize the reality and power of the spiritual in man.

2"Religion," says Conklin (The Direction of Human Evolution, p. 162), "cultivates faith, hope and love"-at least, we may add, when it is socially normal. We might add that religion in its normal aspects is a sort of idealization of the life process-a kind of "eosmic optimism," so to speak. It necessarily includes, therefore, "an implicit theory of the universe," as Webb points out (in Group Theories of Religion and the Individual). 
is a many-sided phenomenon. (1) In one aspect it is participation in, and universalization of, the ideal values of the social life. (2) In another aspect it is a form of social control, constraining through supernatural sanction the individual to conform his beliefs and actions to those of his group. (3) In another aspect it is a consecration of individual life and energies to social ends. (4) Finally, it is an affirmation of the reality of "the spiritual," and a belief in its ultimate dominance and triumph in human life. We may, perhaps, accept as nearly synthetizing the truth in all of these conceptions of religion, the statement that "religion is man's attitude toward the universe regarded as a social and ethical force." 1 Some attitude of this sort, some religious attitude, in other words, is necessary to every thinking man who does not, ostrichlike, refuse to confront the reality in which he lives and moves and has his being. But the religious attitude, evidently, must undergo many changes with the development of man's mind and civilization.

\section{'A detailed study of religious evolution would, of course,}

'Barton, The Religions of the World, p. 3. Compare Caird's definition (The Evolution of Religion, vol. I, p. 30): “A man's religion is the expression of his ultimate attitude to the universe, the summed up meaning and purport of his whole consciousness of things." The synthetic nature of religion as a cultural complex is what gives rise to the many one-sided conceptions of religion and its many various definitions. (For a brief survey of the various definitions of religion, see Leuba's Psychological Study of Religion, Appendix.) It is doubtful if even in its earliest beginnings religion can be reduced to simple psychological elements. From its very start it seems a synthesis (like so many other cultural complexes) of the individual psychic and the social. Thus Carpenter in criticizing the view of Miss Harrison (Themis, pp. 482-92) that religion is slmply the reflection of the social conscience very rightly says (Pagan and Christian Creeds, p. 261): "Religion has its origin not only from unity with the Tribe, but from the sense of affiliation to Nature." This may be implied even by Miss Harrison when she says (Themis, p. 482): "It is not herd instinct, nor the collective conscience, not the social imperative that constitutes religion; it is the emphasis and representation of this collective conscience." 
be necessary to reveal all of these changes and the full significance of religion in human society. That the limits of this work forbid; but some sort of outline of the changes in religion and of the functioning of religion in the social life is necessary for a clear understanding of our subject. No one can understand religion, as has been well said, without understanding other religions than his own, any more than one can understand language without understanding other languages than his own. All religions are vitally related. ${ }^{1}$ From the most highly. developed to the most lowly there are intellectual clews running back which are of the utmost value for the understanding of the relations of religion to civilization. Let us very briefly sketch, therefore, the evolution of religion.

If we take the commonly accepted seven stages of religious evolution, namely, pre-animism, animism, totemism, ancestor worship, polytheism, henotheism, and monotheism, it is not difficult to see that they not only embody man's valuation of his world but also the social values of the age which they represent. These seven stages are, of course, in human history not clearly delimited. ${ }^{2}$ They overlap and even exist side by side; but they mark, logically, definite stages in the evolution of the religious consciousness.

See Marett, Anthropology, Chapter VIII.

2 The presentation of these seven types of the religious consciousness, as an evolutional series, has been vigorously criticized of late (see Schleiter, Religion and Culture). In reality the series is psychological rather than chronological. It is easy, therefore, to find peoples low in culture among whom several of these types of religious consciousness exist alongside of one another and more or less confused. This is, indeed, the usual situation. There are good psychological grounds, however, for believing that the psychological order of filiation is that here presented though it is impossible to present inductive proof of this, as the religious beliefs of even existing savages are an indefinite mixture of the first three or four types. 
Thus anthropologists tell us that there is every reason to believe that the earliest and most primitive stage of religion was the stage in which men simply believed in the pervasion of nature everywhere by a mysterious wonder-working energy, such as the manitou of the American Indian or the mana of the Melanesian. Islanders. ${ }^{1}$ It was in this stage, which may be designated as that of pre-animism, or "manaism," that the conception of the "sacred" or "divine" arose." This may be illustrated by the Melanesians' use of the word mana. This word was used by the Melanesians to signify a power or influence not visible, and in a way supernatural, showing itself in connection with both persons and natural objects. $^{3}$ Fear and reverence were always attached to any person or thing which manifested mana, and thus such persons or things were "taboo;" and upon this idea. of taboo the whole conception of the "sacred" as a means

'Miss Ivy G. Campbell in her study of "Manaism" (American Journal of Psychology, January, 1918), concludes that "manaism as well as animism results from the tendency of the human mind to interpret things in terms of its own inner experience." Manaism, she says, therefore, is not prior to animism if animism equals "the reading of one's own experience into other things." Dr. Marett, however, using the word "animism" in its more exact sense, finds (The Threshold of Religion) that prior to animism proper there must have been a more primitive stage of animatism, that is to say, "manaism." So, too, Professor Boas says (Handbook of American Indians) that the fundamental concept of the religious life is "the belief in the existence of magic power which may influence the life of man and which in turn may be influenced by human activity."

'Dr. Marett says (The Threshold of Religion, Second Edition, p. XXXIII) : "I do not hesitate to regard the general notion exemplified by mana as the category that most nearly expresses the essence of rudimentary religion." But he wisely adds, "What I would not be prepared to lay down dogmatically or even provisionally is merely that there was a pre-animistic era in the history of religion when animism was not." See also Chapter I of his book.

Codrington, The Melanesians, p. 118 following.

- Marett rightly holds that "Tabu is the negative mode of the supernatural, to which mana corresponds as the positive mode." See The Threshold of Religion, Chapter IV, on "The Conception of Mana."

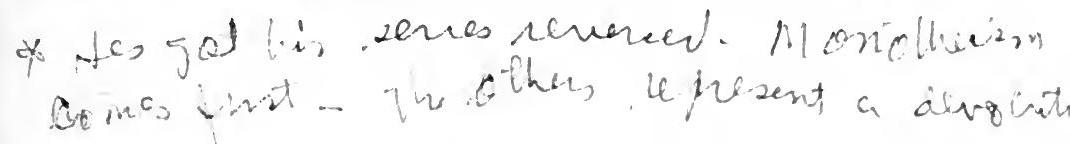


of social control seems to have been built up. The world was filled, in other words, with a mysterious, wonderworking energy which was the source of all success, luck, or good fortune, and which must be dealt with in a certain way in order to insure these desirable effects both for the individual and for the community. The American Indian had much the same conception in such words as manitou ${ }^{1}$ and wakonda, ${ }^{2}$ and among many other primitive peoples we find parallel conceptions. Nothing was more important for the individual or the community in this stage than to get into right relations with this mysterious, wonder-working power which assured good or bad fortune. Hence already, though there were no "gods," the whole mental and social machinery of religion was at work with respect to the mores in the way which we have already described.

The second stage of religion came when this mysterious, wonder-working power was conceived of as a "double" or a "spirit" which resided in men, animals, and things. This stage is technically known as "animism" in the strict sense. The mysterious, wonder- $\overline{\text { working }}$ power was conceived as able to exist apart from the object in which it resided. Thus was born the conception of the "soul," a conception which was bound to be reached by man's power of abstraction, but which was made easier through man's reflection upon the expericnces of his dream-world. ${ }^{3}$ Out of the dualism of the ordinary and the extraordinary, the natural and the supernatural, grew the further dualism

${ }^{1}$ See the classical paper by Jones, The Algonkin Manitou, included in Thomas, Source Book for Social Origins, pp. 683-692.

"See articles, "Wakonda" and also "Orenda" in Handbook of American Indians.

- For a brief critical discussion of animism, with a statement of divergent theories, see Leuba, Psychological Study of Religion, Chapters IV and V. 
of the physical and the spiritual; and the mysterious, wonder-working powers were identified with the spiritual beings, the "souls" or "doubles" of men, animals, and things. A further step in the development of religion is shown in animism, because man more definitely interprets his world in terms of himself, of his will, and of his values. This stage prepared religion to develop and emphasize the subjective element, and to make that the chief element in social control.

A third stage of religious development was "totemism," in which animals or plants became the chief objects of religious veneration. ${ }^{1}$ The totemic stage arose naturally from the manaistic and the animistic, and marked a broadening of man's knowledge concerning his world. It was correlated with the hunting stage of economic development. Man was surrounded by animals, he hunted animals, he lived on animals, he thought in terms of animals, and therefore, his main objects of religious veneration wère animals. It was the zoomorphic stage of religion. $^{2}$ The mysterious, wonder-working power was the

1 The controversy over the relation of totemism to religion has been prolonged and varied. Many writers (e.g., Frazer in his well-known work, Totemism and Exogamy, vol. IV, p. 27) have denied that totemism may be considered a form of religion at all. Durkheim, on the other hand, in his Elementary Forms of the Religious Life, Book II, makes totemism the root or original form of all religion and identifies its fundamental concept with mana. The general view of anthropologists, however, is that there was a pre-totemic stage in which manaism and animism in various forms existed. On the relations of manaism and totemism, see Marett, op. cit. p. 20 f., and the article "Totem" by Hewitt in the Handbook of American Indians. The best brief study of totemism is probably that by Professor A. A. Goldenweiser, "Totemism: An Analytical Study," in the Journal of American Folk Lore, vol. XXIII. For an extended discussion of totemism as a form of religion, see Durkheim's Elementary Forms of the Religious Life, Book I, Chapter IV, and Book II.

${ }^{2}$ Much animal and plant worship, however, exists independent of totemism. For criticism of the idea that totemism involves the worship of the totemic animal or plant, see Durkheim, op. cit. p. 139. 
animal or plant which was regarded with religious reverence and conceived of as having some mysterious relation to the group, which usually bore its name. Kinship and religion now become definitely allied, and hence we may say that this was the first stage in which religion came to have an organized control over all the forms and relationships of social life. Art, educaton and food-getting, also, now come under well-defined religious control.

The fourth stage of religious development, the heroancestor-worshipping stage, did not arise until the patriarchal family and pastoral industry, together with the power of the war chief, emphasized the human element. Thus the anthropomorphic stage of religious evolution was reached. ${ }^{1}$ The mysterious, wonder-working powers were now conceived to be the souls of departed heroes or ancestors. Each family had its own gods and its own domestic worship. This stage fostered the development of the domestic virtues, accordingly, and of the social ideals derived from the domestic virtues; but it had a great drawback in that, by apotheosizing the departed ancestor, it emphasized too much the values of the past. Religion took on an ultra-conservative nature and made possible such static civilization as was, for example, illustrated

In Chapters V-VII of Book II, Durkheim criticizes the idea that totemism is a development of animism. See also W. W. Thomas' article on "Animals" in Hastings' Encyclopedia of Religion and Ethics.

${ }^{1}$ That is, the typical or developed anthropomorphism. Some degree of anthropomorphism is, of course, to be found in the earlier stages of religious development. Thus the attitude of the savage toward his totem animal is as personal as toward one of his tribesmen. Perhaps the great significance of ancestor worship in religious and social development has never been better stated than in Herbert Spencer's Principles of Sociology, Part I, though Spencer was mistaken in supposing ancestor worship to be primitive. The best picture of an ancestor-worshipping society is to be found in Fustel de Coulange's Ancient City. 
for centuries by the Chinese. The abuses of religion, from a social point of view, now begin to appear.

When small ancestor-worshipping groups were welded into city-states or small nations, the gods of the different groups, who included not only the heroic ancestors of the past, but also many nature spirits whose worship had survived from animistic times, formed a "pantheon" and

5) we have the stage of religion which is known as "polytheism." In this stage there is a classification of gods. Not every blade of grass had a god, but there might be a god of the grass. Neither did every man have a god, but there was a god for practically every social activity of man, a god of war, a god of love, etc. All were highly personalized beings, and the community of gods was conceived as more or less like the community of men, though often idealized. This stage was really transitional, and is marked by a confusion of ethical and religious conceptions and values. There was in it, therefore, the opportunity for the sanction of all sorts of practices, and the abuses of religion become more manifest, as seen, for example, in the various practices of idolatry.

Out of polytheism slowly developed another intermediary stage of religion known as "henotheism," in which one of the gods of the pantheon was chosen by a people as its particular national god, without their denying at first, however, the existence of other gods. Gradually the other gods came to be regarded as "false gods" and the national god as the true god. Most monotheistic peoples have passed through this henotheistic stage, though students of religion have sometimes failed to recognize it. The early Jews, for example, before the later prophets were unquestionably henotheistic. This national stage of religion served greatly to unify peoples in strong nationalistic groups. It is a serious question whether 
our civilization is not yet mainly in this stage of religion. Religion in this stage is crudely anthropomorphic, and the deity is thought of as having the national character of the people with very definite human traits.

True monotheism is reached only when the mind of man sees that there is but one universal existence from whence all things, including his own mind, have proceeded and of which they are a part. Monotheism, in other words, is the recognition of the infinite as God, "the infinite and eternal energy from which all things proceed and to which all things return." Monotheism itself has several distinct phases or stages of development. One of these, deism, we have already noticed as the crudest and most popular form of monotheism. Another, pantheism, tends to identify God with the impersonal forces of the universe. In our civilization, however, monotheism has tended to take a more social and spiritual form, known as ethical theism, and probably rightly, since mere "energism" satisfies neither the emotions nor the intelligence of man. Under ethical theism, idealistic social values have been more readily given a religious sanction, that is, universalized or projected into the universe, than under any other form of religion. Thus through ethical theism, though it is a form of religious consciousness to which the masses even in Christian lands have only partially attained, social idealism has been stimulated as never before in the history of civilization.

Now this rough outline of the development of religion shows clearly enough that religion has evolved with the social and mental life of man; that it is a thing which changes with the whole cultural complex which we call "civilization;" and that changes in religion have been 
correlated with changes in man's social and cultural life in general. Clearly enough, too, human history has been, from one point of view, a struggle to attain to a rational and truly social religion-such a valuation of all the experience of life in terms of the universe as accords with man's reason and yet intensifies his social values. Only to an absolute skeptic would the great stages in religious evolution appear other than as steps in social and cultural progress.

It is clear also that through all of its history religion has been a "control" over social life, an instrument of social adaptation; and we are now better prepared to understand its function in maintaining social order and in aiding social progress. How has it affected these vital matters in the social life of humanity in the past, and how may it influence them in the future? Let us take up first its influence upon social order.

From the earliest ages, and through all the revolutions of religion, its chief social function has been to support the "mores" of the social group in which it has been found. Strictly speaking, all religions are ethical in the sense that they support the customary morality of their groups. ${ }^{1}$ The inculcation and support of ethical ideals, or idealistic aims, is of course a late development in religion, but even the most primitive religions support custom. "The religion of a savage," says Dr. Marett, "is his whole custom so far as it appears sacred." 2 The primitive conception of the "sacred," as we have seen, was something which was forbidden, or "taboo." But the thing which was sacred or "taboo" was, in reality, some

${ }^{1}$ Compare Ames, Psychology of Religious Experience, pp. 285-287.

'Anthropology, p. 213. 
custom or usage which the group desired to maintain; and anything which was contrary to that custom was forbidden. Thus the concept of the sacred became attached to the custom, or socially sanctioned usage, itself. Primitive "mores" thus became hedged around with "taboos" or with positive religious sanctions. Whatever the group found to conduce to personal and social safety came to have the sanction of religion attached to it. Now this early connection between primitive morals and primitive religion was not accidental; it was logically and psychologically necessary. The very conception of a superhuman, wonder-workin power in nature was largely obtained by the projection into nature of that psychic element in experience which the social life had developed." The whole world of experience was thus made, so to speak, sociomorphic. The wonder-working powers to be feared and propitiated were thus inevitably associated with the activities of the group. Those activities that were successful, that were accompanied by good luck, were in harmony, manifestly, with the superhuman power; that is, they had mana in them. On the other hand, those activities which did not succeed, or were accompanied by ill luck, had no mana, that is, were opposed to the superhuman power. Thus religious sanction came naturally to attach itself to those modes of conduct of which the group approved; that is, to those which had been found safe and to conduce to group welfare. Hence social obligations became religious obligations even in the lowest forms of social life of which we have knowledge. From their very method of development, therefore, religious beliefs become early entangled with moral standards and ideals. They are built up from social experience and they function toward social ends.

Almost any religious concept or belief will illustrate 
this. Let us take, for example, the concept of God. ${ }^{1}$ When we examine the concept of God among any people we find that invariably it is built up from their social experience. In the earliest religions the gods are often zoomorphic, we have seen, because in the hunting stage of culture the experiences of the social life lead to a high valuation of the shrewdness, power, cunning, and perhaps, the helpfulness of the animal which is hunted. At a very much later date the concept of God represents particularly some personal trait or character which is valued by the group such as the power of the warrior, the wisdom of the judge, or the magnificence of the monarch. The idea stands, in other words, for the ideal of personal character which has come to be peculiarly appreciated by the group, such as the character of some ancestor or king. But the god is always thought of as a member of the group, and as in a peculiar way safeguarding its social life. The values found in the god-concept, thus are always derived from social experiences of one sort or another. As Professor Ames says, "The growth and objectification of the god goes hand in hand with the social experience and achievements of the nation." 2

This is well illustrated from the religious history of the Hebrew people. Their concept of Jehovah gradually expanded from that of a tribal, national god of patriarchal and kinglike character, who was lord of the tribal host, to that of a universal deity, father of all the nations of the earth, possessing not only the attributes of patriarch, but also those of a social redeemer and savior. Moreover, nearly all of the values which came to be attached to the

1 This whole chapter has more or less centered on the evolution of the idea of God, because this idea plays such a prominent part in religion that it illustrates well the development and functioning of the religious consciousness in general.

Op. cit. p. 113. 
god-concept among the Hebrews, it may be added, were directly derived from the social experiences of Hebrew family life. Jehovah as the father of his people came to be thought of not only as demanding obedience and service, but as representing a father's love and care, and so as becoming the redeemer of his people. Indeed, the reason for the superiority of the religious conceptions of the Hebrews is not far to seek. It was because Hebrew social life, particularly Hebrew family life, was of a high type, presenting at its best a unity and harmony which was scarcely attained by any other people of antiquity.

Other religious concepts than that of the deity illustrate equally well the fact that they are built up from social experiences and psychologically are projections of social -values. The concept of the immortality of the soul, which we find more or less developed in all religions, is simply an indefinite extension of personal and social values. When we find a separation in the life after death of the souls of good and evil men, heaven, or the abode of the righteous, is pictured as an ideal society, such an ideal of course as the social life of the people of the time permits. Finally, the concepts of personal responsibility and of individual freedom in working out one's own destiny which we find so generally associated with higher religions are clearly social values. Without the inculcation to some extent of the doctrines of personal freedom and responsibility, orderly social groups can scarcely exist. These illustrations suffice to show that among every people religion is identified with the most intimate and vital phases of the social life; that the ideal values of each type of social development tend always to religious expression. ${ }^{2}$

But why should social values express themselves re-

2 Ames, Psychology of Religious Experience, p. 283.

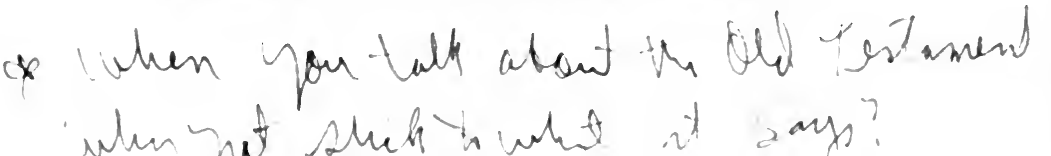


ligiously, it may be asked? Is not the fact that they are social values, built up from real experiences, sufficient sanction for them, without attaching to them theological or mythological notions? This latter form of the question indicates, of course, a misunderstanding; for a religious sanction given to social values, does not necessarily imply the attachment to them of definite theological notions-it only implies that they are made universal, and, as it were, absolute. We have, accordingly, already answered the question why social values need the sanction of religion. It is because religion universalizes them and presents them to the mind of the individual as absolute values. Just as we cannot and do not act upon intellectual concepts without universalizing them, so the most fundamental social values must be universalized and made absolute, as it were, for the mind of the group before they will be acted upon with that unanimity which social order and solidarity demand. Of course it does not matter if minor social values are not thus universalized, because variations in minor details of conduct are usually of no great importance to group life. But the fundamental, intimate, vital values of the social life must be brought to individual consciousness in the intensest way, that is, they must be given religious expression, and so universalized, if the group is to preserve its harmony, efficiency, and capacity to survive as a group.

To put the matter negatively, a religionless world would be one in which there were no absolute values. Values would thus tend to become individualized and be at the whim and the caprice of the individual. But human societies cannot exist upon such a basis of the absolute individualization of values. Certain values the group must have generally accepted to preserve its integrity at all. Such, for example, are the values connected with life, 
with endurance and suffering, with loyalty to group interests, with good will among the members of the group, with mutual service, and with mutual sacrifice for the sake of mutual aid. Men everywhere, have to confront their world with hope and courage, and faith, on the one hand, and with loyalty, good will, and devotion to their fellows, upon the other hand, if human life is to be lived together successfully. Now religion by universalizing these values gives a fuller meaning to life, encourages hope, strengthens endurance and suffering, intensifies loyalty to the ideals of the group, prevents pessimism, despair, and degeneracy. Thus it increases stability of character in the individual which, in turn, makes for harmonious as well as stable relations among individuals. $A$ religionless social world would be a social world of uncertainties, destitute of enthusiasm, and of vision, reduced to the dead level of individual expediency. It would be a social world in which neither harmony nor good will could long prevail. ${ }^{1}$

This is not to say, of course, that morality of a high type cannot exist, in civilized human society, in non-religious individuals. That is possible, because morality is so largely a thing of habit and of custom; a non-religious individual living in a society which universalizes its social values might exemplify the moral ideals of his group in the fullest degree simply through customary imitation and the power of personal habit. ${ }^{2}$ But to admit the possibility of such highly moral individuals who are genuinely

1 Following another line of reasoning, Professor Conklin in The Direction of Human Evolution reaches substantially the same conclusion, p. 168: "We shall never outgrow our need of religion, as we shall never outgrow our need of government and science."

'Ames, however, contends (op. cit. p. 359 f.) even that genuinely non-religious persons are always lacking in the sense of ideal values which constitutes the social conscience.

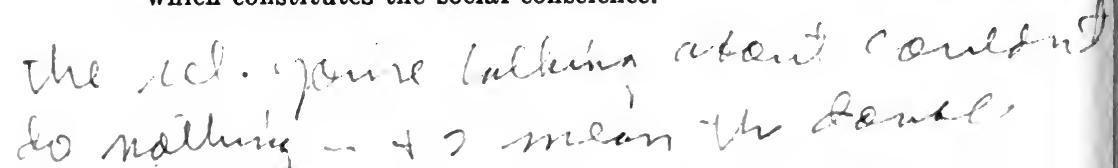


non-religious in a social life pervaded by high ethical standards is no proof that we can have whole civilizations highly moral and at the same time genuinely non-religious. A religionless civilization presents an entirely different problem from a religionless individual. Such a civilization has never existed in the world and the reason should now be obvious why it cannot exist.

Let us look a little more intimately, however, at the nature of human civilization "and (why it presupposes religion for its development. The most careful studies of anthropologists and sociologists have shown that every civilization develops about certain "pattern ideas" or dominant social values. This is true even of the material aspects of life so far as they become rationalized and cultural. Thus in the making of stone implements we find primitive man following out a certain pattern and perfecting it until he comes to the point where he develops another pattern and perfects that, and so on. Thus civilized human society has been built up very much like the great mechanical inventions of the present time, say, for example, the steam engine. Without some "pattern ideas" in the mind to follow, manifestly the steam engine could not have been perfected. So, too, social organization and relationships have largely developed in the same way, upon the basis, of course, of the instinctive ends and needs of men.

Thus, even in the most primitive times men apparently reflected upon their habits or ways of living with one another and approved of some and disapproved of others. Those usages or habits which were approved of and connected with the idea of the welfare of the group became the "mores," or customs, of the group. Thus certain pattern ideas, as regards social relationships, certain social 


\section{THE RECONSTRUCTION OF RELIGION}

values, became connected with the social life of the group. These were gradually perfected and systematized so that out of them social institutions arose. But the "mores," as we have seen, were imbedded in religious feelings and beliefs, that is, they became absolute social values, with a superhuman sanction attached to them. Without such a sanction these pattern ideas and social values, at least in so far as they concerned a supersensible world, would never have been copied by generation after generation. The "mores" would have broken down and social discontinuity would have resulted. Thus the social significance of religion has been, in the past, in the support which it has given, in all stages of human culture, to custom, moral standards, and moral ideals. It is easy enough to say theoretically that morality is something separate and distinct from religion, but practically, they have always gone hand in hand.

But it may be asked if science cannot take the place of religion in giving a "relatively absolute" or universal character to the social values or "pattern ideas" which we must follow for the development of our culture. It has done so in the material realm, where now we ask no further test of the value of an ideal than its practical utility. Why can it not do so in the social realm? The reply is that the higher social values have a different character from these material values. They cannot be tested even by the experience of a single generation to say nothing of the experience of a single individual. The social sciences, therefore, cannot furnish the same test to the individual mind of their values as the physical sciences. Take the value of "good will," for example. It is evident that the individual in his experience may find it of very limited validity. Again, if we take such a value as 
"self-sacrifice," even to the point of death, for the sake of one's country, or of humanity, it is evident that the individual can find no such validity in such an action as he would in adapting means to ends in physical nature. The social world $i$, if we may be allowed to use the expression, a world of transcendental ${ }^{1}$ values, a world of supersensible things and relations. Science alone, accordingly, can never give to social values, in the mind of the individual, that universal and absolute character which they need to possess; or rather, it can do so only in proportion as it transforms itself, as Comte said, into religion. It is thus that social science instead of becoming a substitute for, and displacing religion, leads to the perception of its value; for it finds no other way of making absolute and unquestioned the fundamental values of our social life than through religion.

Civilization, however, as we have seen, must be acquired by each generation. Its values have to be learned by each individual as he comes on to the stage of life. From the nature of these values, as we have just seen, they cannot be adequately tested by the experience of the individual. They must rather be accepted by him as coming from a source whose validity transcends even that of his own experience; that is, they must be taken up by him from "the social mind," the store of ideas and values by which men have learned to regulate their conduct. But to learn such values thoroughly and to make them more powerful to regulate conduct than the sensuous experiences of life means that such moral values must have a religious sanction attached to them or else they will fail effectively to control conduct. Thus the "mores" of our age, not less than of previous ages, need the support of

1 We use the word to mean "transcending the experience of the individual." 
religion. Idealistic social morality without any religious sanction, so far as social science can see, is an impossible dream; and the more complex our social life becomes, demanding more complex and difficult adjustments on the part of the individual, the more impossible a high social morality without a correspondingly high social religion becomes. The death of religion would accordingly mean the death of all higher civilization.

The social need and the social power of religion are now manifest. Let us, however, reiterate what we have already said about the possibility of religion becoming a reactionary rather than a progressive force, a support for the evil in the social life rather than for the good. The religious problem is not simply the problem of the maintenance of religion in human lfe. For reasons, which we have already seen, probably there is no such problem as that; for if we do not have a rational and ethical religion, the mind of man is such, we have seen, that we are bound to have irrational and unethical religion-if not a religion of social progress, then a religion of social retrogression and barbarism. Religion may become attached to any of the mores of society, to any human institution, to any social order, no matter how barbarous it may be; and when religious sanction has become attached to any social value it is more difficult to change that value. Civilization might die from a barbarous or reactionary religion as well as from lack of religion. Hence the real religious problem of our society is to secure the general acceptance of a religion adapted to the requirements of continuous progress toward an ideal society, consisting of all humanity.

In part, the backward tendency of religion, when it manifests itself, comes from its necessary function as a 
conservator of social values. It is a means, as we have seen, of conserving customs and habits which have been found to be safe by the group, or which are believed to conduce to group welfare. It surrounds itself, accordingly, with prohibitions and "taboos" of actions of which the group, or its dominant class, disapproves. It lends itself easily, therefore, to maintaining a given social order longer than that order is necessary or even after it has become a stumbling block to progress. For the same reason religion is easily exploited by a dominant class in their own interests. It is in this way that religion has often become an impediment to progress and an instrument of class oppression. It is thus, also, that it has raised up enemies for itself who see nothing in it but its negative and conservative side. Writers of strong antireligious bias emphasize this negative and conservative aspect of religion, but it is not infrequently emphasized overmuch by the friends of religion.

Now, however important the socially conservative nature of religion may be; whether it be, as one writer declares, a reaction against social degeneracy; or as another writer says, "the force of social gravitation that holds the social world in its orbit," it is a mistake to think of religion mainly as negative and conservative in our social life. In a static society, which emphasizes prohibitions and the conservation of mere habit, religion will also, of course, emphasize the same things; but there is no necessity that it should do this. In a progressive society religion can as easily attach its sanctions to conduct and to ideals which are progressive as to those which are static. In other words, religion can as easily attach its sanctions to social ideals beyond the existing order of things as to the existing order. Such an idealistic religion will, however, 
have the disadvantage of appealing mainly to the progressive and idealizing tendencies of human nature rather than to its conservative and reactionary tendencies. A socially progressive religion, to find wide following and acceptance, presupposes a high development of intelligence in the mass of individuals. This is doubtless the reason why progressive religions are exceedingly rare in human history, taking it as a whole, and have appeared only in the later stages of cultural evolution.

Nevertheless there is an intimate connection between social idealism and the higher religions. These religions have, for the most part, gotten their ideals from the family life; and sociology shows that social and moral ideals in general have come from the primary forms of association, such as the family. ${ }^{1}$ Social idealism is an attempt to realize in the wider social life (that is, the life of classes, nations and races) these primary ideals which are gotten from primary groups; the higher ethical religions got their ideals from the same source and have the same aim. They are, therefore, but manifestations of social idealism imbedded in religious feeling and accompanied by more or less formal religious sanctions.

In the higher stages of cultural revolution, then, religion comes to reinforce and sanction social progress. Setting its seal of approval upon an ideal social life not yet realized, it gives to such a "pattern idea" a force and power which it could get in no other way. Religion thus becomes a powerful social dynamic and an instrument of progressive social order. It sets up a "utopia" which gives a goal and a meaning for the whole social life. If this utopia is in nationalistic terms it of course powerfully reinforces the national spirit. If, on the other hand, the

${ }^{1}$ See Chapter VIr. 
utopia is in humanitarian terms it reinforces the humanitarian trend of civilization. ${ }^{1}$ Thus the goal sanctioned by religion may become a powerful social dynamic, transforming in time the whole social life.

It is a matter of supreme importance, therefore, in our social life to see that religion sanctions right social ends. It is only a religion which stimulates a humanity-wide altruism in the individual which is adequate as a foundation for social progress. Through humanitarian religion, a religion which stimulates such a humanity-wide altruism, quite evidently class, tribal and national ethics can be transcended and replaced by humanitarian ethics.

It may be said, of course, that humanitarian ethics does not need humanitarian religion, but all human experience opposes such a conclusion, and we have seen reasons why this must be so. Indeed, humanitarian ethics demands more in the way of self-sacrifice from the individual than class, tribal, or national ethics. It makes, in other words, the least appeal of any system of morality to the natural egoism of the individual, because it concerns the largest possible human group, having to do with the welfare of many individuals of whose existence the average individual knows nothing directly through experience, and concerning whose welfare he can have tangible ideas only through the exercise of the liveliest imagination. If humanitarian ethics is to succeed in overcoming the conflicts between classes, nations, and races, which are now tearing asunder our world, it must have the support of a religion of humanity. ${ }^{2}$

1 By humanitarianism, we mean, following Hobhouse (Morals in Evolution, Vol. II, p. 249), the doctrine which "makes the furtherance of the collective life of humanity the supreme object of endeavor." Hence similar meaning attaches to the phrases humanitarian religion, humanitarian ethics, humanitarian civilization, etc.

2 It is just because religion supports, develops and completes ethics that developed religion, as Hobhouse says (Morals in Evolution, Vol. 
Many religions have, of course, approached the humanitarian viewpoint or developed humanitarian principles as incidental to their main teachings. Thus the great purpose of Buddhism is undoubtedly to put an end to human sorrow and suffering. To this end it not only counsels the avoidance of inflicting all pain or suffering upon living creatures, and pity, gentleness, and charity in all human relations, but also the cessation of all striving and desire on the part of the individual in order that the incidental suffering may be escaped. Buddhism is, in brief, a doctrine not only of selflessness, but of quietism. . At first glance it would seem to be supremely humanitarian, and it has often been thus represented. But its humanitarianism is negative rather than positive. Its negative attitude toward life prevents it from developing a positive doctrine of the development of humanity. It seeks escape from life and its evils rather than the development of life through mastery over its conditions. Passivity rather than activity is its goal. Its humanitarianism resembles closely the spurious humanitarianism of the present day which regards all suffering as evil. The final judgment of science concerning Buddhism, despite its noble qualities, can only be that it is fundamentally nonsocial in its ideals and hence that it fails to furnish the religious values and ideals needed for a progressive civilization.

Mohammedanism, also, in some of its later developments, especially in Bahaism, ${ }^{1}$ has shown a strong humanitarian trend. But Mohammedanism, so far as it has raised itself above Semitic paganism, is based on Judaism

II, p. 255), has its firmest root in ethics, and that "Ethies becomes the test to which religion must submit." (Ibid., p. 252.)

${ }^{1}$ Bahaism in its origin was an offshoot of Mohammedanism, though many Bahaists in America regard themselves as Christians. See article, "Bab, Babism," in Hastings' Encyclopedia. 
and Christianity. It was the religion of the later Hebrew prophets, which furnished the enduring base upon which has been built whatever is worthy in Christianity, Mohammedanism, and later Judaism. In the teachings of these men are found the first faint beginnings of that positive humanitarian religion and ethics which has become the hope of the world. It was not until Christianity burst the shell of Jewish nationalism, however, and became an international religion, that the movement to supplant the tribal and predatory traditions of the ancient world by a tradition of universal peace, good will, mutual aid, and brotherhood among men may be said to have been fairly launched.

If what has been said in the preceding paragraph is correct, it is evident that the main stream of religious evolution must be sought in ancient Judaism and Christianity. That this is so, and the scientific reasons for it, we shall endeavor to set forth in the next chapter. For to understand the full social significance of religon, we must understand the social meaning of the Christian movement in particular. 


\section{CHAPTER III}

THE SOCIAL SIGNIFICANCE OF CHRISTIANITY

Tire second thing to be considered in the reconstruction of religion is the social significance of Christianity, in the sense of the religion of Jesus.? We must strive to gain an insight into its place and meaning in social evolution. No historical movement has been more misunderstood, alike by friend and foe, than Christianity. This is largely because of the lack of sociological and anthropological perspective and knowledge. Only the densest sociological ignorance would suppose that the Christian movement is an accident in human history. ${ }^{1}$ On the contrary, like its political counterpart (the movement toward democracy), it is of the very essence of later social and cultural evolution. It is an integral part of the historical process, an essential factor in social evolution. To understand what it means we must try to get a view of the movement of human history as a whole, as it is pictured to us by modern science.

'Anthropologists tell us that the whole culture history of man may be roughly divided into three stages-sav-

${ }^{1}$ Says Professor Case, in his valuable work on The Evolution of Early Christianity (p. 25): "Christianity can be ultimately and comprehensively conceived only in the developmental sense, as the product of actual persons working out their religious problems in immediate contact with their several worlds of reality." 
agery, barbarism, and civilization. ${ }^{1}$ Savagery, in which man is a mere child of nature, living off of the wild fruits of the earth and the animals that he can kill and eat, making no attempt to control his own destiny, lasted for the race at least one hundred thousand years, archae ological evidence shows, while some belated human groups still survive in that state. Barbarism, a traditional stage, in which man begins to cultivate the soil and raise domestic animals, but soon turns his attention to preying upon his fellowmen as an easier method of gaining a livelihood than the mastering of nature, began in Europe about eight or ten thousand years ago with the coming of neolithic man. Militancy and predatoriness were the chief social traits

"This narrower use of the term "civilization" to designate a particular stage of culture, namely, beginning with the keeping of historic records, as it is common both in ordinary and scientific language, should not confuse the reader. See definition of culture and civilization in the broad sense on p. 12. Some authorities would designate that part of civilization which begins with universal literacy or education as the "stage of enlightenment." But there seems no good reason why it should not be regarded as a phase of civilization. The author, therefore, has preferred to keep the ferm "civilization" for the entire stage of cultural evolution which is characterized by control over the social tradition, dividing it into "semi-civilization" (beginning with the invention of writing) and "true or developed civilization" (beginning with universal education). The reader needs hardly to be warned that stages of culture are not sharply defined, that they overlap, and vary greatly in the different peoples.

A different classification of the stages of human culture (or mental and social development) is proposed by Edward Carpenter in his Pagan and Christian Creeds: Their Origin and Meaning: namely, the stages (1) of Simple Consciousness, when man's consciousness is still animal-like; (2) of Self-Consciousness, which began in the barbarism of Neolithic times, and in which man consciously makes self the center of interest, and (3) of Universal Consciousness, a stage just beginning, in which self will no longer be the center, but humanity and the universe. This classification, while suggestive, seems to be based upon the fallacy of regarding "self-consciousness" as synonymous with self-interest or selfishness. Man will probably grow mcre self-conscious, but also more "social" or "altruistic." In any case, true Christianity (despite what Carpenter says to the contrary) might be regarded as marking the beginning of the third stage, "Universal Consciousness." 
of barbarism, and these in turn grew out of a narrow "group morality" and a limited "consciousness of kind." Civilization, in the strict sense, only began with the keeping of historic records, with man's coming to social selfconsciousness, and with his beginning of the control and conquest of the mental or spiritual element in his life. This stage of human history is, then, a thing of yesterday-only in its beginnings, not more than four or five thousand years old for any people, and scarcely two thousand years old for most Europeans. We began to outgrow barbarism, in other words, but yesterday, and it should not be surprising that many of the traditions of barbarism still survive among us. Complete civilization will arrive with the full socialization of man.

To the sociological imagination this development of human culture presents itself as a parabola, with human experience as the chief element at its focus. The lower part of the curve may be taken as representing the not less than one hundred thousand years of savagery, of brute-like ignorance and subjection to the blind forces of nature, through which the race has passed. The upper part of the curve may be taken as the one hundred thousand years or more of civilization, of mastery over physical nature, and human nature, which, we may hope, lies ahead of our race. The remaining or vertical part of the curve will then represent that transitional stage of barbarism through which our race has passed on its way from animality to spirituality, from ignorance to knowledge, from the darkness of savagery to the light of civilization. We might rep' ssent this graphically by the following diagram: ${ }^{1}$

This diagram, like sciences, must not, of rough, convenient mee

il graphical representations in the social urse, be taken too seriously. It is only a of representing an idea. If the curve were 
Evidently we are now just entering upon the upper part of the curve, with the real work and higher achievements of true eivilization still lying all ahead of us.

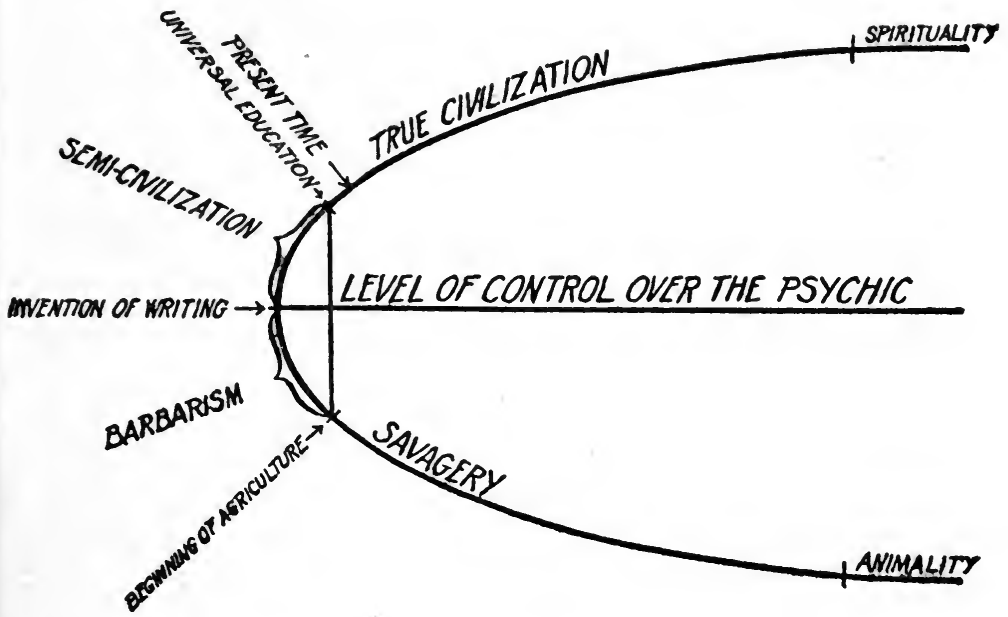

THE CURVE OF HUMAN CULTURE.

The typical institutions of barbarism, or predatory culture, still survive, or but lately existed among us. Yesterday we had slavery, and even to-day we are only trying

drawn accurately it would be very irregular, as human history proceeds by the "trial and error method," a succession of "ups" and "downs," advances and regressions, with progress resulting as a whole, hitherto. An entirely different graph from the parabola might, of course, be used to represent the general movement. Curiously enough, the parabola was selected by Henry Adams (The Degradation of the Democratic Dogma, p. 302) to illustrate pessimistic conclusions which were based upon his attempt to trace physical laws in social movements. No such analogy with the physical is here implied. On the contrary, human history, as a process of learning through "trial and error," is essentially a psychological process. See my Intmnduction to Social Psychology. 
to rid ourselves of polygamy, autocracy, militarism, class exploitation, and the debaucheries of barbarous self-indulgence. (We are still slowly and painfully learning the rudiments of true civilization.

Let us recall again the method of cultural evolution and the importance of "pattern ideas," or "ideals," in the social life, this time not in the way of maintaining social order, but rather in furthering social progress. The transition from lower to higher stages of civilization, anthropologists tell us, is intermediated by the formation of "pattern ideas," or "ideals." ${ }^{1}$ By the principle of anticipation these ideas are often formed far in advance of the complete birth of the new civilization. 'The human mind sees the need or the advantage, sets up an "ideal," a "pattern" of the thing to be realized, and then by various methods works towards its goal. Thus long before men invented the flying machine they formed the idea of the flying machine. Then they watched the flight of birds and other animals and studied the properties of physical nature until they found methods of realizing their idea or ideal of the flying machine. Thousands of such illustrations might be given. All of the important things in human culture, then, exist first as "pattern ideas" in the minds of men before they are realized in actual life; and they exist, as a rule, long before they are realized.

Now this principle applies to the great changes in religion and morals, and so in civilization itself, not less than in the realm of mechanical invention. Such changes come through the starting of new pattern ideas or standards in the minds of men. These are reflected upon by the popular mind, and if accepted and approved

1 See an article by the author on "Theories of Cultural Evolution" in American Journal of Sociology, May, 1918, Vol. XXIII, pp. 779-800. 
they become the "mores," the all-powerful standards, of a new culture. But the pattern ideas or standards of a new culture do not arise gradually out of those of the old culture or mix, in general, harmoniously with them. They arise suddenly as new inventions, new perceptions on the part of social leaders, and cultural evolution proceeds by one type entirely supplanting another type. Thus the standards of the predatory type of culture known as barbarism must be completely supplanted by entirely different standards before we can have true civilization. Nevertheless, the ideals and standards of an older type of culture may persist for an indefinite time alongside of those of a new, while the new type is emerging. Thus arise conflicts between the old and the new; and this explains in large measure the great moral conflicts in our human world. They are conflicts between old and new cultural patterns. As the ideas and standards of predatory culture were thousands of years dominant in our traditions, we must expect them to manifest themselves at times in their old power in the earlier stages of a nonpredatory civilization.

Since the patterns of a new culture concern human relations they demand more than mere intellectual assent. They must become social values with compelling social sanctions. They need accordingly a decided emotional setting in order to overcome the native egoism of the individual, since the break with old habits and the entering upon a new and higher form of social organization entails sacrifices in many cases. This emotional setting the new cultural patterns get through the sanction of religion, in accordance with the principles which we have discussed in the preceding chapter. Hence a revolutionary change in human culture, if it is a social advance, is always preceded or accompanied by a religious reformation or re- 
vival. The social significance of religious reformations, with their revival of intense religious emotions, is that they smooth the way for the. acceptance of new cultural patterns or social ideals. Thus the Protestant Reformation prepared the way for the individual freedom of the modern world. The Methodist movement among Englishspeaking peoples again undoubtedly was a forerunner of nineteenth century democracy in Britain and America. But with those greater revolutions in culture which concern the most fundamental patterns and ideals of social life, a much greater religious movement is needed, more extended in time and more revolutionary in character. Religion functions, as we have seen, to meet the crises of life, and no crisis in social evolution exceeds that of the transition from one type of culture to another. World religions arise to mediate these transitions. ${ }^{1}$ The adaptation of human society to a universal non-predatory type of culture would necessarily require a new religion of international, humanitarian character to broaden man's consciousness of kind.

What Christianity is, from an anthropological and sociological point of view, should now be evident. Christianity is a new set of "pattern ideas," marking the dawn of a new type of culture, a culture with a non-predatory morality on a humanitarian basis. It is an effort to

1 The historical conditions surrounding the origin of new world religions are not fully known, but in every case they seem to be those of great cultural change. This was especially true of Christianity. Those who are familiar. with the social conditions of the early first century in Judea and in the Greco-Roman world generally tell us that there was a peculiar "ripeness" in these conditions for just such a social and cultural change as early Christianity attempted. A part of the conditions under which Christianity originated are vividly described by Simkhovitch in his Toward the Understanding of Jesus. 
transcend predatory individual, class, tribal, and national ethics and to replace these with a universalized, social, international, humanitarian ethics. The beginnings of this movement are, of course, to be found in the many precursors of Jesus, and especially in the later Jewish prophets. But in the life and teachings of Jesus these ideas first came to effective expression. He initiated the revolution in religious and moral ideas for which the whole of human history had been preparing.

Only misunderstanding of human history and of the nature of religion could lead to the supposition that the Christian movement marks merely a stage in the evolution of man's theological beliefs. ${ }^{1}$ Christianity apparently started as a protest against Jewish formalism and particularism. But as such a protest, it had to develop the spiritual and universal side of Judaism, already more or less explicit in the teachings of its later prophets. In Jesus we find the supreme development of this prophetic Judaism with its trend toward ethical and religious universalism. Premising the supreme value of human personality, his clear teaching was that the only possible way to serve God is through the service of men, no matter what their condition, occupation, or nationality might be. Thus he revolutionized both religion and ethics in humanizing both. The humanitarian impulse of the time, accordingly, attached itself to Christianity, which became an idealistic social movement in the Greco-Roman world to supplant its predatory traditions by new ideals of peace,

1 Early Christianity, Case tells us (op. cit. Chapter I), cannot be conceived primarily as "an abstract quantity of doctrine, ethics, or ritual." Rather it was "a new religious awakening," which had its origin in "an outburst of spiritual energy on the part of Jesus and his followers, striving after new and richer attainments under the stimuli of a new and more suggestive environment." (p. 28.) 
good will, mutual aid, and brotherhood among men. ${ }^{2}$

The distinctive note of Christianity was "redemption" -not simply of the individual but of the world. For it looked to the establishment of a social order in which the divine will should be realized-a kingdom of God-an order which should make of humanity one large family with peace, justice, and good will among all its members. But this new. social order was to be established not by

1 In an article in the American Journal of Theology, January, 1918, on "Primitive Christianity an Idealistic Social Movement," Prof. C. W. Votaw, of the University of Chicago, summarizes the socially idealistic aspects of primitive Christianity as follows:

1. Its comprehensive and supreme principle was love of man toward man-brotherliness in feeling, action, and thought.

2. It inculcated the sacrifice of self for the good of others.

3. It made the common welfare the chief aim of life.

4. It sought to establish consideration and justice in the social relations of men.

5. It aimed to diminish the valuation and to check the pursuit of material things.

6. It sought to control and suppress sex immorality.

7. It elevated the marriage ideal and practice.

8. It forbade envy and strife, fraud and theft, drunkenness and reveling.

9. It condemned pride, ostentation, and hypocrisy.

10. It censured the self-complacency, arrogance, and selfishness of the better class.

11. It placed the social duties above the ritual duties, right conduct and character above worship and ordinance.

12. It interpreted the will of God in the direction of reasonable living.

13. It made the individual free, autonomous, responsible.

14. It rebuked legalism in law and in social administration.

15. It sought to prevent the domination of the weak by the strong.

16. It opposed the use of force to accomplish social ends.

17. It undertook to replace the law and practice of retribution, i. e., revenge, retaliation, by the principle of returning good for evil and overcoming evil with good.

18. It created so high and free a conception of the right social relations as to disaffect the Christians toward the Roman Government.

19. It developed local groups of persons throughout the Empire bound together religiously and socially in close fellowship.

20. It unified Orientals and Occidentals in a real brotherhood, surmounting the barriers of race antipathy and national alignment.

21. It brought together on a common plane the rich and the poor, 
force or by authority, but by a new life within the individual soul-a life redeemed from sin and in harmony with the divine will. Christianity ${ }^{1}$ was thus not so much a mere "reform" movement in the external social order as a movement directed at a "revolution in culture," a complete change in the "mores." From the first it was so recognized and fought by the champions and defenders of the older order in which it originated. ${ }^{2}$

the educated and the ignorant, the prominent and the obscure, the master and the slave.

22. It welded new social bonds, detaching people from previous groups and associations and uniting them on a higher basis.

23. It founded a solid, permanent social organization within the Roman Empire that was to survive the latter's decline and fall.

24. It made life idealistic, hopeful, joyful and courageous.

25. It assured men of eternal welfare and a perfect social order in an imminent new age.

"The use of "Christianity" at times as a convenient term for the Christian movement-the movement to establish the religion of Jesus -will, it is hoped, cause no confusion to the reader, as the context will indicate the meaning.

With penetrating clearness a scientific educationist has thus recently characterized the primitive Christian movement: "The Christian movement in its primitive aspects represents a distinct resurgence of life from its natural depths and sources, whatever those sources may be. It is of the nature of a genuine impulse-life, energy, feeling, emotion, purpose welling up from within, out of the individual, out of man, out of the universe, overflowing the conventional channels of life and daring to live in ways that are not permitted by a machine-made age or civilization. . . . It is the denial of the finality of a fixed and mechanical social order. It is the hope of a social order based on the inner and spiritual life and needs of society, an order in which the individual may find his own personal freedom as a member of a social fellowship. It gives the direct challenge to all forms of intellectualisms, practicalisms, legalisms, literalisms, and militarisms. Plato had said, 'The world is made of ideas'; Jesus said, 'Build your world out of love and service and sympathy.' Roman militarism had said, 'Buttress your liberties with forts, arsenals, and legions of soldiers'; Jesus said, 'The truth alone can make you free.' The Scribes and Pharisees had said, 'Cursed is the man that knows not the law'; Jesus said, 'Love is the fulfillment of all law.' In place of the philosopher, the moralist, or the soldier, Jesus sets up a little child and says, 'Of such is the real social order. of the future to be made.' In all these things the founder of this movement seems to be saying: 'Man is a part of the creative energy of the universe; he shall create his own moral order, his own spiritual 
But why did such a movement originate in Judea? Why did it spring up within the confines of Judaism? Doubtless somewhat must be attributed to the fact that in Judea the cultures of the Occident and the Orient met, and that there was the point where new cultural ideals, or "patterns" embodying the best in both, could be most easily developed. The sociological principle of the "crossfertilization of cultures" comes in here. Social developments in the Greco-Roman world, especially Stoicism and increasing cosmopolitan practices, had done much to prepare the way for humanitarian ideas and ideals in religion and ethics. At the same time similar movements were starting in the Orient. That these should have come to focus in Judea is what we should scientifically expect when we clearly understand the nature of Judaism. ${ }^{1}$

universe in which to live.' . . A All the way through the teaching of primitive Christianity the implication is plain that there is quite as much need of the salvation of institutions as of the salvation of individuals."-Joseph K. Hart in Democracy in Edrcation, pp. 121-124.

Thus Dr. Hart finds an implication of that "social statesmanship" in early Christianity which some have denied as existing there. In later chapters he explains fully how in the succeeding centuries Christianity was socially and politically "sterilized."

It will be noted that both Votaw, a student of the New Testament, and Hart, a student of social and cultural conditions, agree with the writer that the early Christian movement aimed at a "revolution in culture," though this has often been denied by theologians. This is also the view of Simkhovitch.

For discussion of the social conception of the kingdom of God, see page 176 in Chapter VI.

i The amount of Greek and Hindu (or other Oriental) influences shown in Jesus's teachings has often been debated. It is sufficient for our purposes, perhaps, to note that while Jesus lived at a "crossroads" of culture which was open to world-wide influences, yet his main teachings were undoubtedly a clear development of those of the later Jewish prophets. It will be well to remember also that the Jews themselves had lived for centuries at this cross-roads of culture; that they had had much contact with other pcoples. Through fully one thousand years of Semitic civilization (Jerusalem already at 1500 B.C., archæology shows, was an important military stronghold and commercial center) they had accumulated much experience and 
For the deeper reason for the development of Christianity in Judea was the nature of ancient Judaism. Unlike many ancient religions it had not wandered off, so to speak, into religious by-paths, but had kept close to the main line of religious evolution as the development and spiritualization of social ideals and values. Psychot logically Judaism was an idealization and projection of the values connected with the family life. All the religious and ethical concepts of Judaism were based upon the family. All of the phraseology of the later prophets especially was borrowed from the domestic and social life. In other words, the ancient Jews had kept a relatively unspoiled family life as the center of their social life, and from the fraternity and idealism of this "primary group" had derived their religious and ethical concepts and ideals. Now sociology shows that the original source of social idealism is in the social experiences in the "primary groups," especially the family and the neighborhood. ${ }^{1}$ All human history is in one sense a struggle to take the fraternity and democracy realized in these groups, when at their best, and make them humanity-wide. Thus Judaism in its development represented the main trend of religious and social evolution, and it only needed to break the shell of nationalistic particularism, as we have said, to become a universal and humanitarian religion.

It was the work of Jesus to broaden thus the religious tradition and to point it to its final goal. Whatever view one may take of his personality, all must admit that the Christian movement received its initial form and impulse

were able to profit from the mistakes of themselves and other peoples in religious matters, as their prophets insist. All of this fitted them to be the chief bearers and refiners of the religious tradition in the ancient world.

${ }^{1}$ See Cooley, Social Organization, Chapters III and IV. 
from him. ${ }^{1}$ It was his creative personality which finally focused all the idealistic trends in the religious and moral life of the time, and brought them to the white heat of a new religion. This again accords with scientific sociological principles; for sociology has shown that-the creative influence of personality is necessary in all human achievement, and that all human progress is achievement." Masterful personal leadership is a necessary element, therefore, in every great social movement toward a higher plane of civilization; and the personality of Jesus furnished, and has continued to furnish, such leadership for the religious and moral revolution which Christianity seeks to effect. [Jesus was not an accident in human history, nor is the recognition of his continued leadership of the Christian morement an accident.

C. We must not look at early Christianity, however, as anything more than a beginning. It has been wrongly regarded by most Christians as marking the completion and perfection of religion and morality. ${ }^{3}$ But Christianity can be this only when the Christian movement has achievod its final development, and has succeeded in establishing a humanitarian civilization, a Christian state of society. Christianity is not a static thing. To regard Jesus himself as standing other than at the beginning of a great new movement in human culture is to misunderstand him culturally and historically. ${ }^{4}$ Even the

${ }^{1}$ A critical discussion will be found in Chapter V, pp. 145-149.

'See The Social Problem, p. 71, also Introduction to Social Psy. chology, pp. 159-161; 219-220.

- See Case, The Evolution of Early Christianity, Chapter I. This is not saying, of course, that Jesus did not enunciate certain final principles in religion and ethics. The whole argument of this book is in one sense an attempt to show that Jesus did.

- Compare the words of Eucken in answering the question raised in the title of his book, Can We Still Be Christians? "We not only can but must be Christians-only, however, on the condition that 
words of Jesus, though they be together with his life the touchstone of the Christian spirit, mark only the beginning of the unfolding of a new conception of human relationships, a social life, non-predatory in character and patterned upon the ideals of good will, mutual service, and brotherhood among men.

Christianity started, then, as a religion of love and of human service, and its permanent successes have largely come through its having this character. Even though the world was not ready to receive and to carry out its principles, and though its followers soon distorted them beyond description, yet impartiality must lead us to acknowledge that it started as an idealistic social movement in the Greco-Roman world, marking the dawn of a religion of humanity. Moreover, it is only fair to add that through all the centuries the best representatives of Christianity have always held to the idealistic social point of view. The place of Christianity in the evolution of religion and its social significance accordingly is clear. We have said that it is an endeavor to transcend tribal and national religion and ethics by a religion of the love and service of humanity as a whole. In other words, it is an endeavor to establish a world-wide, ideal human society, in which justice and good will shall be realized, upon a religious basis. Its aim, as has been well said, is nothing less than the creation of "a new world." 1

Christianity be recognized as a progressive historic movement still in the making, that it be shaken free from the numbing influence of ecclesiasticism and placed upon a broader foundation." (p. 218.)

1 A totally different view of Christianity is, of course, presented by the German theologians. Their views may be found best summed up in Schweitzer's The Quest of the Historical Jesus. According to this view, the teaching of Jesus was eschatological and did not concern this world. This eschatological view of the teachings of Jesus will be discussed further in Chapters V and VI, but it may be pointed

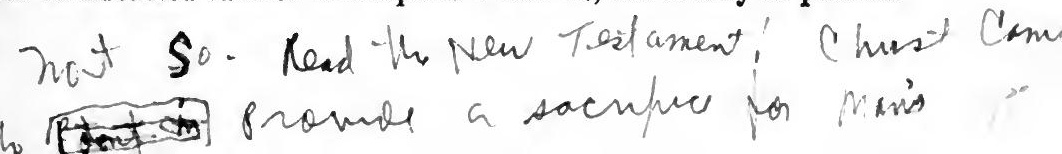


The "Enthusiasm of Humanity," then, as Sir J. R. Seeley said in his Ecce Homo-one of the first books to interpret rightly the religion of Jesus-is the center and core of Christianity. Love was the characteristic virtue of the new religion, but love socially directed, the love of God being expressed and measured in terms of the love of man. Religious faith and enthusiasm were to release the energies of men and make them free to build the divine society-the "Kingdom of God"-in which a redeemed humanity was to be realized. But before this could be done the bondage of the human soul to sin and selfishness, to cynical indifference and unbelief, must end; man must become reconciled to God as Father and dedicated to his cause and kingdom. But Jesus did not conceive that this Utopia could be created merely by changes in individual souls without moral conflicts in the external social order. On the contrary, the Christian life was to be a continual strife against the forces of evil, not only against those within, but also against the wickedness entrenched in the social order and maintained by those in authority. The Christian life was to have its militant side, though its weapons were not carnal. This was necessarily so, for, as Seeley says, "The Enthusiasm of Humanity creates an intolerant anger against all who do wrong to human beings, an impatience of selfish enjoyment, a vindictive enmity to tyrants and oppressors, a bitterness against sophistry, superstition, self-complacent heartless specula-

out here that it was quite natural that such a view should grow up in Germany (especially) where for a long time any attempt to apply humanitarian ideals was regarded with disfavor by authorities in both church and atate. It may also be proper to remark here that the central principle of Jesus-the love and service of man-becomes quite unintelligible (to a plain man) if he meant his teaching to be primarily "eschatological." The whole trend of German theology, indeed, seems at bottom to be hostile to the social conception of Christianity. Compare Thomas, Religion-Its Prophets and False Prophets, especially p. VIII and Chapters VI-VIII. 
tion, an irreconcilable hostility to every form of imposture, such as the uninspired inhumane soul could never entertain."

But if this is the social meaning and aim of Christianity, why, it may be asked, has historical Christianity accomplished so little during all the centuries to establish justice and good will among men? The answer to such a question, if it were to attempt completeness, would have to review not only the whole history of the Christian church, but the whole history of the world since the introduction of Christianity. The chief things in the past which have been obstacles to the achievement of a Christian state of human society, however, may perhaps be summarized under six heads: The first is the fact that Christianity has in the main been taken by professed Christians as a theological and metaphysical doctrine pertaining to the salvation of the soul in a life beyond rather than as a practical ethical and social attitude. The world into which Christianity was introduced was dominantly theologically minded, ${ }^{1}$ and it has remained in that state until very recent times. The second obstacle which Christianity as a social and ethical system encountered was the pagan religions and morals of the ancient world, with their sanctions of barbarism, which, we shall try to show in the

'Says Wells (Outline of History, Vol. I, pp. 591-592): "Jesus had called men and women to a giant undertaking, to the renunciation of self, to the new birth into the kingdom of love. The line of least resistance for the flagging convert was to intellectualize himself awa from this plain doctrine, this stark proposition, into complicaled theories and ceremonies. . . . By the fourth century we find all the Christian communities so agitated and exasperated by tortuous and elusive arguments about the nature of God as to be largely negligent of the simpler teachings of charity, service and brotherbood that Jesus had inculcated." An excellent discussion of the reasons for the failure of the teachings of Jesus to be understood by his followers will be found in Thomas's Religion-Its Prophets and F'alse Prophets (Macmillan, 1918). 
next chapter, have very definitely survived even in the traditions of our present civilization. From the first, the pagan state of religion and morals forced Christianity in practical life to compromise; and pagan habits of thought and feeling made it almost impossible for all except a few minds to comprehend the meaning of the social teachings of Christianity. ${ }^{1}$ The third obstacle to the social success of Christianity has been the failure of its representatives to appreciate the importance of the material and economic factors in the life of man.

Man is not only a spiritual being with spirituai, that is, social and ethical, wants; but he is also a material being hemmed about by the forces of the material world $\{$ His spiritual life can only blossom and come to fruitage under favorable material and economic conditions.] If it is true, as Jesus said, that "man does not live by bread alone," it is also true that man cannot live without bread. The material wants of life must be satisfied, in other words, in some proper measure before the spiritual life can have a fair chance to develop. The social ideals of religion, if they are to be practical, cannot concern themselves exclusively with the immaterial things of life. The ery of the masses for bread must not be met by presenting them a stone, in the form of ethical truth regarding the value of a mind above the things of this world. Nor did Jesus so teach or so act, one cannot but remark. When religion develops this sort of other-worldliness, ${ }^{2}$ it is bound to be-

${ }^{1}$ See Glover, The Conflict of Religions in the Early Roman Empire.

2 Much of this "otherworldliness" of primitive Christians was, of course, due to their Millenarianism, and through all the Christian centuries Millenarianism has been an influence which has kept the church from undertaking its true task. See Chapter VI. Says Professor E. C. Hayes (Sociology and Ethîcs, p. 1): "The substitution of a mystic doctrine of the 'second coming' for the practical purpose for which the founder of Christianity lived and died is the most pathetic of all perversions of a noble teaching." 
come a stumbling block to human progress, and to be accused of being merely a means to quiet the justifiable discontent of the suffering masses. Now the social failure of historical Christianity in the past has been largely due to the non-recognition of this truth; and this is the main reason why some men have lost their faith in the social power of religion.

A social and humanitarian religion cannot regard anything in human life as alien to itself. In a sense it is concerned as much with the material conditions of life as with the spiritual, ${ }^{1}$ because it does not conceive that social redemption is possible without control, for the sake of the higher social values, over all of the conditions of life. In other words, it is quite as much the aim of social religion to transform the environment in which the individual must live as to bring to the individual soul redemptive truth and spiritually uplifting influences; and it is the material, quite as much as it is the spiritual environment which must be transformed, if social religion is to succeed in its great work of creating an ideal human society in which justice and good will shall be realized. To this point we shall return again.

A fourth thing which has been an obstacle to the achievement of a Christian state of society during the last few centuries, has been the extreme individualism of Protestant Christianity. This has led to "an absence of the sense of responsibility for the social order which has, from the beginning, maimed and distorted Protestant Christianity." 2 It tended to render, in many cases, the religious life of Protestant peoples a socially sterile subjectivism and to narrow the object of religious enthusiasm

${ }^{1}$ See Chapters VIII, IX and X. book.

${ }^{2}$ Fitch, Preaching and Paganism, p. 67. Compare p. 113 of this 
from the redemption of humanity to the redemption of a few individuals. Even yet some Protestant denominations have scarcely freed themselves from the blighting influence of such religious individualism.

A fifth obstacle, closely akin to the last, to the realization of Christian ideals in social life, has been the unintelligent use which Christians have made of the Bible, often taking all parts as equally inspired and on the same plane. The result has been that the teachings of Jesus have been often neglected and that the actual Christianity taught has been a strange mixture of Old Testament religion and Pauline theology. ${ }^{1}$

A sixth obstacle to the social success of Christianity has been its failure to ally itself with humane science. The church hitherto has failed to see that the great enemy of mankind is ignorance. It has failed to understand that the redemption of humanity, the creation of an ideal society in which the divine will shall be realized?. can be compassed only through a full knowledge of all the forces which make or mar human life, both individually and collectively. Instead of devoting itself to the promotion of such knowledge, the church has often presented the

1 A professor of religious education in an orthodox school of religion writes me: "Preachers still pay more attention to Paul's theology than to the teachings of Jesus. There are two reasons for this: The orthodor notion of inspiration puts Paul's teachings on a par with those of Jesus; and this has made it easier to preach theology than to preach social Christianity because theology is in the realm of opinion, while social Christianity is in the realm of everyday life."

For an interesting attempt to dissociate the teachings of Jesus from Pauline theology, though often crude and uncritical, see Singer's The Rival Philosophies of Jesus and Paul. Safer guides, however, will be found in such works as Kent's Social Teachings of the Prophets and Jesus, Chaps. XXV, XXVI, and his Work and Teachings of the Apostles; Smith's Guide to the Study of the Christian Religion (see especially Chaps. V and IX); King's Ethics of Jesus; and Mathew's The Bocial Teaching of Jesus. For a view the opposite of Singer's, see Bacon's Jesus and Paul, especially Lecture III. 
sorry spectacle of opposing the advance of science, and especially its extension to human affairs.

Not only must the failures of historical Christianity be fully recognized, but we must also recognize the frequent failure hitherto of all humanitarian religion for the reasons just mentioned. The social failure of religion, however, is like the social failure of science; it has been a failure at times to envisage the whole of the social reality and the whole of human life. In our rapidly changing and increasingly complex social world such failure is to be expected. Only a religious or scientific dogma which fails to see that religion is a growing, evolving thing, still to be perfected, would throw aside religion because it has failed in the past and is still very far from meeting the full needs of our social life. All of our institutions are failures in this sense. Yet one who would discard the family or government, for example, because they have failed in the past and still fall short of meeting the requirements of our present civilization, would be foolish. The most conspicuous failure of all, the candid scientific mind will readily admit, is science itself. For modern science until very recently has conspicuously failed to envisage human life as a complex whole, and even in many instances, indeed, to take cognizance of social reality at all. Yet the scientific mind does not lose faith in science because of the failures of science. On the contrary, because of its method and its aim the very failures of science are an incentive to the further development of science.

In the same way the failures of religion attest to its supreme worth and in all rational minds are an incentive to its further development. No human institution has grown in any other way than through successes and fail- 
ures; and one must admit that the failures of institutions have more often contributed to their rational development than their successes. The hopeful thing in this world of ours is that human life and civilization are ever turning defeat into victory. It is time that those who see the social value of religion-who see that religion is not less needed than science to meet the problems of our complex human living together-should rally and turn whatever defeats religion has sustained into victory. The development of humanitarian religion is only just beginning; ${ }^{1}$ but it must be developed on a world-wide scale if humanitarian civilization is to go forward with its work.

Moral renewal is now obviously the one thing most needed in Western civilization. COnly the development of vital, humanitarian religion can save Western civilization from defeat. If this is so, there is urgent need of a revaluation of Christianity. For, as a great secular newspaper has recently said, ${ }^{2}$ one might as well forget the law of gravitation in the physical world as to ignore in the social world the ethical principles which Jesus enunciated. Humanity would be about as safe in the one case as in the other, as the recent history of the world sufficiently attests. Many social thinkers of the present see that the world needs a rebirth of vital religion, but many of these fail to see that a foundation was laid in religion and ethics by Jesus as stable as the foundation laid by Copernicus in astronomy or by Darwin in biology. They look for a new religion. In the autumn of 1914 the writer heard in London a great English social thinker say that he saw

${ }^{1}$ Conservative scientifie estimates place the duration of man's life upon earth at not less than 250,000 years. Compared with this long past, as has often been pointed out, Christianity has been at work only a few minutes.

'The Nation, December 21, 1918 (Vol. 107, p. 762). 
no way out of the present crisis in our civilization unless there should perchance again arise a religious leader of the simplicity, dignity, and exaltation of character of Jesus of Nazareth, who could lead the nations to peace, justice, and brotherhood. But with much more insight into our social and moral problems, as well as into the nature of Christianity, Henry C. Emery, formerly a professor of economics in Yale University, has said: "We are told by some writers that the world is waiting in an agony of expectation for some great social philosopher who shall bring to it the new message of salvation. If so, the world is wrong, for there is no message to bring it peace from its manifold ills, save that heard nineteen centuries ago from the profoundest of all social philosophers, the Man of Nazareth." 1

With dispassionate impartiality, Professor Ross, too, has said: "I suppose that all students of society would accept something like this as the formula for social progress: The maximizing of harmony and co-operation and the minimizing of hostility and conflict. Now when you stop to think of it, is it not wonderful that in the Gospels we find provided just the religion which is best suited to realize the sociologists' ideal? From the point of view of improvement in human relations, humanity has in this religion an asset of indescribable value." ${ }^{2}$

2 Quoted by Strong, The New World Religion, p. 479. In a public lecture before the University of Colorado, August 10, 1921, Dr. A. B. Wolfe, professor of economics and sociology in the University of Texas, whose entire detachment from all traditionalism is well known, similarly declared: "The Western world needs to be converted to Christianity almost as much as it needs conversion to science. By Christianity I mean precisely the ethics of Jesus."

So, too, Professor Simkhovitch says: "Christ's insight was one which future generations may rediscover but can never upset." (Toward the Understanding of Jesus, p. 59.)

Proceedings of the American Sociological Society, Vol. XIV (1919), p. 133 . 
The fundamental principles of Christianity, in other words, are in harmony with the fundamental principles of social science, and the world needs only to develop and apply those principles to have a religion in accord with modern social science. That scientific knowledge of human relationships should point to the same conclusions reached in religious development two millenniums ago will surprise no one who understands the principles of social evolution $^{1}$ which we have set forth in the preceding chapter. And the specific reasons why Jesus headed the movement for a social world patterned upon the relationships and values of the family life we have just indicated.

If that movement was not a mistake, the world surely needs to acknowledge anew the leadership of Jesus, and this means that we need a rebirth of Christianity in the sense of the religion of Jesus. It is time that organized Christianity become synonymous with the religion of Jesus. The vision which Jesus had of a social life based upon love or good will is not an unrealizable dream. It is the only possible social future if the world is not going to turn back to barbarism. Men have never intelligently tried to realize it in their social life. Instead they have been satisfied with various cheap substitutes in the form of theological beliefs which have diverted their attention from the true problems of the religious life or with formal pretensions which have thinly disguised their underlying paganism.

'Similarly Wells (Outline of History, Vol. I, p. 584) says: "Though much has been written foolishly about the antagonism of science and religion, there is indeed no such antagonism. What all world religions declare by inspiration and insight, history, as it grows elcarer, and science, as its range extends, display (as a reasonable and demonstrable fact) that men form one universal brotherhood, that they spring from one common origin, that their individual lives, their nations and races, interbreed and blend and go on to merge again at last in one common human destiny." 


\section{CHAPTER IV}

\section{OUR SEMI-PAGAN CIVILIZATION}

The third thing which is needed for the proper reconstruction of religion is the perception of the essential paganism and barbarity of our present civilization.] "Wo must see our present so-called civilization," as justly says a recent writer," "for what it is-a thing of barbarism, feeding upon the life of the race in the poverties of peace as well as in the woes of war-and get rid of it forthwith!" The immediate and momentous question before the world is what sort of civilization we shall aim to achieve; whether it shall be patterned after the ideals of the Christianity of the Gospels, or developed along other lines. Do we want a Christian world or not? This has become the momentous question before our age because the ethical ideals of Christianity have been challenged in recent years as never before in the history of Western civilization, and pagan views of life have been openly advocated. The trend in Western civilization as a whole for several years immediately prior to the breaking out of the Great War was unquestionably away from Christian ideals. ${ }^{2}$

2 Dr. John Haynes Holmes.

- Unscientific observers prior to the Great War were almost invariably optimistic, as critical mindedness towards one's own civilization, if rational, requires considerable scientific detachment. This was particularly true of the daily press in the United States. But the war shattered the foundations of this uncritical optimism, and some at least were led to take a more critical attitude. The following paragraphs, taken from an editorial which appcared in one of the 
While this fact was appreciated by practically all careful students of Western civilization, whether they were sympathetic with Christian ideals or not, yet the Christian church as a whole, and especially its leaders, remained strangely blind in the matter. In the autumn of 1913, for example, the writer spoke before a large church in one of our great cities, pointing out the trend in recent years towards a recrudescence of pagan ideals and practices in our civilization. To his surprise he found the next morning not only that he was denounced in the newspapers as a "pessimist," but that also all except two of the Christian ministers of the city who had been interviewed upon the subject disagreed with him and appar-

more ably edited metropolitan American dailies in February, 1919, illustrate this and form a valuable bit of testimony:

"For many years before the war we in America had been hearing how much better the world was becoming. Outwardly there was some proof of it. Slavery had vanished as a human institution, the inquisition and the rack had gone to shameful oblivion, religious intolerance was passing, woman was being lifted from the position of chattel to one of equality with man-in fact, the superficial manifestations of a better life were many.

"Inwardly, however, we have been traveling the wrong road. Hypocrisy and sham were becoming national fetiches. Our most sublime institutions were being perverted to base commercial ends. Honesty was being measured by ability to keep out of jail, shady adroitness and border-line shrewdness in business were magnified as great virtues, while upright, unyielding honesty was sneered at as a concomitant of failure.

"Even the very church was prostituted in the pursuit for money. Preachers in many instances contorted the word of God to meet the wishes of rich parishioners; others preached charity as the only real virtue, knowing that the wealthy in their congregation had money to give their fellow-man, but nothing else. Crooks and sharpers became deacons and pillars, for under the cloak of a religious life they found it much easier to flece the widow and the orphan.

"The money lust infected our courts, debauched our literature and our schools. The successful man was the rich man; others were failures. Children were taught to be good business men, good traders, honest if possible, but successful at all events. The Golden Calf had a place of honor in all the meeting places of men."

The present tendency to attribute everything which we judge to be wrong with our civilization to the effects of the war is, of course, entirely uncritical. 
ently thought that he was attacking the church. Within a year, however, the atrocities of the German armies in a score of Belgian cities gave startling evidence to the world of the trend toward paganism in our civilization. The Great War, indeed, revealed the unpleasant fact that our civilization was still not far removed from barbarism. $^{1}$

Men began to ask many questions. Has Christianity as a social system proved a failure? Is a Christian society possible? Is Christianity "irretrievably obsolescent"? Are not human brotherhood, universal justice, and universal good will but idle dreams, " a species of oriental mysticism," in a world ruled by force and swayed by individual and group egoism? In order to be honest, should we not frankly go back to paganism as our rule of life?

- Destructive criticism is not a pleasant task, especially not to the writer of this book. He hopes that the reader will understand that such criticism is here undertaken with a constructive purpose, and undertaken only because twenty-five years of careful study of all phases of our civilization have convinced him of the substantial truth of the conclusions herewith presented. The main argument is not retrogression, but the survival in our civilization of pagan and barbarous elements, which recrudesce in periods of change and confusion like the present. This allows, however, for some degree of real retrogression in certain respects. This, indeed, every scientific student of civilization expects, since history shows, not uniform progress, but an alternation of progress and regress with, of course, a balance on the side of progress in the long run.

While the writer believes that he has presented a "true bill" against nineteenth century mores, he sees no cause for discouragement in the facts mentioned or in the present situation, if people can be awakened to the falsity of the standards by which they have tried to live. He would not even agree, therefore, with the relative pessimism of Professor Santayana, who in his recent book on Character and Opinion in the United States, says (p. VI) : "Civilization is perhaps approaching one of those long winters that overtake it from time to time. A flood of barbarism from below may soon level all the fair works of our Christian ancestors, as another flood two thousand years ago levelled those of the ancients-such a catastrophe would be no reason for despair-under the deluge and watered by it, seeds of all sorts would survive against the time to come." 
But what do we mean by "paganism?" Fundamentally we mean the type of social life and the ethical ideals which Machiavelli and Nietzsche discovered, or thought they discovered, in the civilization of Greece and Rome previous to the adrent of Christianity - a type of society, in other words, in which power and pleasure are frankly avowed as the ends of individual and group action. Machiavelli found in pre-Christian Rome his great model. The career of that world-conquering state, he thought, showed that the only end of the state was power, that men were exclusively moved by pure self-interest or egoism, and that public policies could not be based upon Christian morality. His ideal was that of the ruthless militant state, whose only aim was the expansion of its power and ultimately world dominion over other peoples. In much the same spirit Nietzsche discovered in pre-Christian Greece and Rome the foundation for his doctrine that power is the supreme aim of all life. It was Greece rather than Rome, however, which especially afforded Nietzsche his model. The Greeks, with their child-like joy in life, their love of pleasure and amusement, their sensuous aestheticism; the Romans, with their frank acceptance of power as the only end of public policy; the ancient Teutonic tribesmen, with their joy in battle and in the exercise of ruthless might,- -all these appealed to Nietzsche as so much in line with his social ideal, that the coming of Christianity to disturb this "natural order" seemed to him the greatest calamity in human history.

Of course, the situation in the ancient world was not so simple as Machiavelli and Nictzsche pictured it. There was no single form of paganism; there were many forms, and even in pre-Christian times there was a striving towards something higher than the immoralism which Machiarelli and Nietzsche admired. Thus in Greece, 
Socrates, Plato, and Aristotle attempted to refute the Sophists with their doctrines that "might makes right," and that "pleasure is the good." But as Nietzsche says, the movement which Socrates, Plato, and Aristotle stand for, was not truly representative of Greek life. Nietzsche regards them as corruptors of Greece, much as Christianity was later of the whole world. ${ }^{1}$ The true Greece of history, we must admit with Nietzsche, was the Greece of the Sophists and Epicureans. The true Rome was not that of Seneca and Marcus Aurelius, but that of Caesar, Nero, and Trajan. The Roman Empire rested essentially upon the predatory use of brute force, upon the subjugation and exploitation of weaker peoples, with scarcely any aim beyond that of world dominion. Greece, with its sensuous aestheticism, and Rome, with its brutal predatory militarism, have been perhaps the chief sources of corruption in the traditions of our civilization; but the Teutonic tribesmen of the north with their predatory traditions might be considered as furnishing a third source of paganism almost as important as the first two, were it not for the fact that these tribesmen later accepted GrecoRoman civilization and largely supplanted the models of their culture by the models of Greece and Rome.

On the whole, then, Machiavelli and Nietzsche were right in finding a distinct type of culture, antecedent to our present civilization, which the Christian movement tried to set aside. The student of civilization is familiar with that type of culture also among non-European peoples. He finds that it characterizes all peoples living in or just emerging from the predatory stage of culture which we have described as "barbarism." All barbarous peoples possess as one dominant characteristic of their culture crude ideals of power and pleasure as the proper ends

${ }^{1}$ See The Will to Power, pp. 345-366. 
for action of both individuals and groups. Indeed, other ends of action scarcely occur to them; and as these are the ends set before both individuals and groups, such peoples are possessed by illusions of advantage to themselves in the domination, spoliation, or exploitation of others. "Paganism" is therefore simply the moral and religious equivalent of "barbarism" as a cultural term. "Paganism," or "barbarism," evidently underlay, in the main, the culture of Greece and Rome. It also evidently underlies the culture of the present, since it is that stage of culture which lies back of our civilization and from which we are but just emerging.

What is the relation of the religion of Jesus to the pre-Christian religions and morals which we have termed "paganism"? It was an effort, as we have shown in the previous chapter, to transcend these and to furnish a new set of social patterns of a universalized humanitarian character with a religious sanction. The new pattern ideas of social relationships which the Christian movement initiated were in necessary conflict with those of the older predatory civilization in which they started; and this conflict has continued down to the present time. Even now, after two thousand years of slow emergence from barbarism, the world seems about to relapse back into it. Nor is this difficult historically to understand. From the first so-called Christian civilization has been a very mixed affair. Much even in the Christian church has been non-Christian, or rather stark paganism. ${ }^{1}$ Through all so-called Christian centuries pagan ideals have been uppermost in polities and in business, and often in literature, in art, in ethics, and in religion. The Greco-Roman

${ }^{2}$ As one of my colleagues says, there are even yet so many pagan survivals in the chureh that effective religion of ten finds it necessary to express itself through other agencies and organizations. 
ideal of life has more often triumphed over the Christian ideal than most Christians are willing to admit. Ever and again there has been a recrudescence of the pagan ideals of power and pleasure as the chief ends of life. The Renaissance was especially marked by the recrudescence of paganism. Indeed, as one impartial writer has put it, "The ideal of the Renaissance was to restore pagan standards in polite learning, in philosophy, in sentiment, in morals." 1 Not simply Machiavelli and Nietzsche, but a whole series of men of thought and men of action have at one time or another advocated the restoration of pagan standards in whole or in part in our civilization.

Modern civilization has, indeed, been an inharmonious synthesis, or rather a continuous conflict, between these antagonistic views of our social and moral life. In the minds of some this has been interpreted to mean that the elements of worth in what we call "paganism" are so great that they must be given equal validity with the social values set up by Christianity. But it may be pointed out that there can be no compromise between a socialized morality and religion, and the ethics of power and pleasure for which paganism stands. There can be no compromise between humanitarian eivilization and barbarism, and therefore none between Christianity and individual or group egoism. This is not to deny that certain elements in the pagan ideal of life may have worth. The self-culture, the happiness and joy in nature and in life, and even the love of power which paganism so stressed, have their place in a humanitarian civilization; but theirs is not the first place. ${ }^{2}$ The first place must be given to

1 Santayana, The Winds of Doctrine, p. 38.

2 The argument of this book is, of course, that the Christian ideal of service of mankind presents that synthesis of the Greek ideal of self-assertion and the oriental ideal of self-renunciation which Hobhouse points out as necessary. (The Rational Good, p. XVIII.) 
the sense of social obligation, to the desire to serve and benefit mankind, not only all who now exist, but who may exist in the future. Such a social point of view must lead, moreover, to a policy of social conservation and of social self-realization rather than to one of self-gratification and self-culture. Service becomes the chief end of life for the individual, and also for groups, rather than power or pleasure. Pagan ideals will cease to be dangerous when they are definitely subordinated to the Christian ideal of life, but only then. Our civilization needs a synthesis of its inharmonious elements, but it can get that synthesis only through accepting the fundamental Christian principle that the service of God must consist in the service of mankind.

Modern civilization has been troubled by the recrudescence of pagan ideals only because it has not definitely accepted the Christian ideal of life. ${ }^{1}$ Power and pleasure have remained its chief ideals. Even when these have not been held up as ends for individuals, they have been held up as ends for groups. We must not, of course, blame overmuch the influence of pagan antiquity for this. While the world has never succeeded in ridding itself of the ideals of barbarism, or rather in definitely subordinating them to higher ideals, the conditions of our own time, together perhaps with certain tendencies of human nature, are even more responsible for this than the tradition of our pagan past. In other words, many conditions in the modern world have released and powerfully stimulated the original selfish impulses of human nature. During

'Says Professor Conklin (op. cit. p. 170): "When one reflects on the fact that for nineteen centuries so great a part of the world that professes to be Christian has remained heathen at heart, and that to-day the teachings of Jesus are generally regarded by his so-called followers as too lofty to be practical, we may well wonder whether mankind is making any progress in religion." 


\section{OUR SEMI-PAGAN CIYILIZATYON 101}

the nineteenth century external authority of every sort declined to a minimum in Western civilization, and no new means of adequate social control were developed. The authority of the church, for example, reached its low ebb, and, under the assaults of criticism which was merely destructive, ${ }^{1}$ the authority of the Bible waned. At the same time through invention and discovery and the opening up of unexploited regions of the earth, wealth increased to an extent beyond the dreams of previous ages. Even though the increase of wealth did not occur in all classes, the increase affected the standards of living and conduct in all classes. A greater number of individuals found it possible to devote themselves to selfish aims, to the getting of money, of power, or of pleasure than ever before, and the example of these individuals affected all classes.

Thus by the decline of external authority and the increase of wealth human nature suddenly emerged in the nineteenth century from its swaddling bands, as it were. The flood gates of human selfishness were opened wider than they had ever before been opened to the masses of men. At the same time, a gospel of individual and national success was preached everywhere. Material standards of life came to dominate among the masses. All these things made a swing back toward paganism inevitable in the later years of the nineteenth century and in the earlier years of the twentieth. ${ }^{2}$ Literature began to

1 A fully scientific criticism would, of course, have been constructive. See Chapter V.

2 We must always remember, as was pointed out at the beginning of Chapter III, that we began to outgrow barbarism but yesterday. In the early stages of civilization, in which we still are, we must expect frequent relapse into barbarism, as human history proceeds by the "trial and error method." Such relapses will continue until the mass of men have learned to discriminate between the pagan or barbarous elements in our culture and the Christian. 
take on a pagan cast, such as it had not had even in the Renaissance. In commerce, in business, in polite society, and in amusements pagan standards came more and more to the front. A large element in the privileged classes refused to recognize or to conform to any standard at all save their own pleasure and their own wishes. They belittled by contemptuous indifference, if they did not ridicule outright, Christian standards in living and in conduct. Scandalous divorces and marriages became common to an extent that the world had not seen since the decadent days of Rome. The wealthy set an example of extravagance, luxury, and fast living which inevitably demoralized the rest of society. But these were only straws upon the surface. The program of self-interest, material satisfaction and brute force came to extend through and through the fabric of Western civilization. ${ }^{1}$ It was not simply the moral standards of the individual which were rebarbarized, but, as we now know, the life of whole nations. ${ }^{2}$ It was, indeed, in the realm of politics and of international relations, a realm which had never been greatly influenced by Christian standards, that

${ }^{1}$ Says Bishop F. J. McConnell (Journal of Religion, Vol.I, p. 198): "The whole atmosphere in which the present generation has been reared has made for individualism and for the search for as much personal profit as can be found anywhere. . . The problem is that of the transformation of an entire social climate."

2 "A prominent and conservative university president recently said in public that the present age is the most decadent in history, with the exception of the days just before the fall of the Roman Republic and before the French Revolution. He mentioned 'dishonesty permeating public and private life alike, tainting the administration of justice, tainting our legislative halls, tainting the conduct of private business, polluting at times even the church itself.' In the same utterance, he averred that ' $a$ source of infinite evil in every modern society is impurity of word and act.' He went on to assert that 'if there is to be social and political regeneration in our Republic and in the rest of the world, it must be by a tremendous regeneration of moral ideals." "Hudson, The Truths We Live By, p. 22. 
the recrudescence of paganism was chiefly to express itself.

Strive to ignore it as we may, the real causes of the Great War were in the "mores" of Western civilization. And that these mores were fundamentally pagan or antiChristian does not admit of doubt. In concrete terms, the causes of the Great War were pagan mores in political life, , in business life, and in social relations in general. AntiChristian politics, anti-Christian business, anti-Christian ideals of life, not pressure of population upon material resources, not geographical conditions, not biological necessities connected with race, were the real causes of the great conflict. These causes were everywhere in Western civilization, but they particularly came to a head in Germany. Germany can be blamed for the war only to the extent that Germany led in re-paganizing the world. The dominance in Germany of a militaristic tradition, the rise there of imperialistic commercialism, and the undermining of Christian ideals of life among the Germans by these two causes and by the rise of a destructive criticism of religion and ethics and of a materialistic science, fitted Germany to bring to a focus all of the anti-Christian forces in modern civilization. She became the "scourge of God" to show the nations the evil of their ways.

But, of course, anti-Christian or Machiavellian politics was not confined to Germany. Though Frederick II, Bismarck, Treitschke, and a host of lesser German political thinkers formulated Machiavellian politics into an odious creed and justified it, yet their formulations were but little more than statements of the actual practices of many European states. At the very time, indeed, this odious pagan political philosophy was taking shape in Germany, Great Britain and Russia were permitting no ethical scruples 
to stand in the way of their imperialistic ambitions. European nations in general, as a recent writer has said, whatever their attitude toward Christianity as a private faith, deliberately accepted the thesis of its social impracticability. The statesmen responsible for the diplomacy of various European countries took it for granted that self-interest must be the supreme law of nations, and public sentiment sustained them in this attitude.

Practically all of the nations of Europe, indeed, played the game of "grab and get" through the whole of the nineteenth century with seemingly little suspicion that it was destined to bring upon them the direst sort of punishment. Germany was the only one that had the hardihood to formulate this policy into a political creed and, as it were, officially to adopt it. In this Germany is especially to be blamed, for in a sense the individual or nation which deliberately adopts a creed of anti-social conduct is more dangerous than the individual or nation which occasionally indulges in such conduct. Beliefs, ideals, standards ultimately determine the character of nations as well as of individuals. And Germany openly and unashamedly professed pagan political ideals while other nations, though often practicing them, yet disavowed them, and even just before the Great War in some cases seemed on the point of repenting their practice. But the evil spirit of Machiavelli with his doctrines that the only end of the state is power, and that in politics the end justifies the means, dominated the whole of Western civilization during the nineteenth century.

Back of the anti-Christian politics of the modern world stood anti-Christian business. In an era of the worldwide expansion of industry and of the economic exploitation of the earth, it was easy for the economic doctrine 
to grow up and receive general acceptance, that business was for profits only. An imperialistic, capitalistic industry grew up, which set before itself as its one end the domination of the world's markets for the sake of profits. This imperialistic capitalism found a ready tool in Machiavellian politics and in the growth of a hypernationalistic spirit. The whole commercial and industrial world of Western civilization became organized on essentially pagan lines. Profits, dividends, economic success, were aimed at, no matter what the expense to humanity. Self-interest was held to be the only possible basis for business enterprise, and this self-interest was usually interpreted to mean merely the interests of the business man as an individual. The obligations of business even to the community were overlooked, to say nothing of its wider responsibilities to humanity at large.

Within the national life itself this anti-Christian spirit in the commercial and business world had a most disastrous influence. The gospel of self-interest came to dominate not only industrial life but it spread to all other phases of the social life. Even the family life came to be looked upon as a matter of private convenience. No matter how carefully the young were instilled with Christian ideals in the home and in the church, as soon as they got into the business world they felt compelled to lay aside these ideals and to adopt the pagan code of business morality, that in business self-interest alone must guide one's conduct. Consequently business paganized a part of their life insidiously before they knew it; and gradually their whole moral life became weakened and undermined. The reactions of pagan business upon the public life of the nation were not less insidious and corrupting than upon its private life. Newspapers became filled with details how big business and little business did not scruple to do 
anything to insure profits and dividends. Exploitation of the economically weak, cynical disregard of human rights, and even revolting inhumanities in industry alienated economic classes, thus sapping the foundations of democracy, while corporations often maintained they had the privilege of exploiting the public by graft and corruption. Municipal governments were corrupted in many cases, state legislative bodies were bribed, ${ }^{1}$ and when the United States government in the early years of the twentieth century undertook to insist, in even a slight degree, that business should be put upon the basis of public service, nearly the whole of the big business of the country threatened to go upon a "strike," so little did the patriotic, to say nothing of the Christian, spirit permeate the larger business interests of the nation.

A reflex result was that self-interest and class interest became in the nineteenth century the maxims of the laboring class also. The ideal of public service in laboring class movements was subordinated or forgotten. As the gospel of self-interest dominated the relations of employer and employee, the interests of the two were held to be diametrically opposed. Consequently there grew up the doctrine of class war with at least an implied correlated doctrine of class hate. Christianity, rationality, and altruism were scouted and even scorned as possible means for the solution of economic problems. The only solution of the problem of the relations between economic classes, nineteenth-century popular socialism held, was the forcible overthrow of the capitalist class by the working class. It is not too much to say that Marxian socialism, in particular, took as its immediate goal the inspiring of the working class with the desire to dominate and destroy

${ }^{2}$ See R. C. Brooks, Corruption in American Politics and Life. 
other social classes. As one of its most conspicuous exponents has said in effect, its aim was to teach the working class to "combine the old weapons of criticism with the new criticism of weapons." In other words, Marxian socialism openly advocated the settlement of economic grievances between classes by resort to force. By the end of the nineteenth century, accordingly, Western civilization was confronted by a well-organized movement among the laboring classes, which was openly atheistic, materialistic, and consciously aimed at class domination. The disastrous results of developing working class movements upon the pagan basis of self-interest and class interests must now be sufficiently evident from the case of Russia. But it is well to remember that the adoption of the predatory standards of paganism by a part of the laboring classes in Western civilization has been largely, if not entirely, a reflex of the practices of the socially more fortunate classes. In other words, anti-Christian business has been largely responsible for the anti-Christian phases of working-class movements.

Deeper than anti-Christian politics or anti-Christian business were anti-Christian ideals of life in Western civilization generally. Civilization is made up of traditions, and traditions are made up of thoughts. The thinking classes in any cultural group, therefore, are ultimately responsible for the guidance of its civilization. Back of them, to be sure, may lie traditions and objective circumstances which influence their thought, but this fact does not detract from their responsibility as the creators and leaders of civilization. To get at the real ideals which animate any civilization, we must turn, therefore, to its literature, its art, its science, its religion, in brief, to the ideals and standards of its educated and socially privileged 
classes. What were the ideals and standards of the educated classes of Western civilization before the Great War began? Were they dominantly pagan or Christian ideals?

If we turn to literature first, we find that a large part of the literature of the later nineteenth and earlier twentieth century was totally regardless of Christianity, ${ }^{1}$ that it derided or ignored Christian ideals. ${ }^{2}$ We are not, of course, speaking of Christianity as a theology, but of Christianity as a system of ethics and of social life. European literature revelled in a purely destructive criticism of the traditional morality of Christendom in the family, in business, in general political and social relations. The representatives of these tendencies were not a few minor literary men with no standing, but included the foremost names in the literature of the day. Moreover, the writers who exploited these tendencies were usually the most popular ones, especially among the educated classes. An indication of the moral condition of the intellectual classes may be found in the popularity in the later nineteenth century of the old Persian poet, Omar Khayyám, whose frankly pagan view of life seemed greatly to delight many intellectuals. But some found the rela-

1 In an article on "Is Modern Literature Christless?" in The Christian Century, April 14, 1921, Dr. Joseph Fort Newton answers: "Much of it is. Most of it, indeed, is written as if Christ had never lived."

It is invidious, of course, to single out examples, but to illustrate our meaning we might take Samuel Butler's The Way of All. Flesh, a book which, while it justly satirizes a pseudo-Christian society, is itself purcly pagan in its point of view. No book has been more popular among the intellectual classes during the past twenty years.

${ }^{2}$ Says Professor E. C. Hayes (Sociology and Ethics, p. 2): "Moral disintegration is by no means peculiar to Germany. A large part of our own popular fiction consists in the subtlest advocacy of a pseudoscientific immorality. ... We are assured that nothing is wrong that is 'natural,' that in nature there is no higher and no lower, that altruism is only a form of selfishness and that reason has no precedence over the instincts that we share with the beasts." 
tively luxurious and effeminate paganism of such writers as Omar Khayyám not sufficiently strong for their taste. They preferred writers whose works, as has been said, it was irrelevant to criticize as immoral because they intended to be immoral. ${ }^{1}$ The whole decadent school of literature and art regarded the moral standards of Christianity as the most worthless sort of rubbish.

The most fearless, most consistent exponent of this school was, of course, the German philosopher, Nietzsche, whose writings would deserve further consideration at this point if we had not already sufficiently indicated their importance for the understanding of the deep pagan current in our civilization. Nietzsche cannot possibly be dismissed as an exceptional, aberrant type; nor was he peculiarly German. A host of kindred writers were grouped about him in every country of Western civilization. He was, therefore, profoundly symptomatic of the spirit of his time, and, indeed, as we have already indicated, he will become in the future either the leader of the re-paganization of the world, or else the last of the great pagans of the nineteenth century to pass into oblivion. We cannot escape Nietzsche when we confront the problem of our civilization. Yet his influence was political only indirectly, and economic scarcely at all. Rather the influence of Nietzsche and his kindred spirits was upon the general ideals of our social life. That the influence of these writers was tremendously anti-Christian there can be no doubt. For, regard the Nietzschean philosophy as we will, it can be summed up in a single sentence, that the only obligations which the individual needs to concern himself about are those of his own self-interest, and that the teachings of Jesus are the

${ }^{2}$ The New Republic, January 12, 1918, p. 312 (Vol. XIII). 


\section{THE RECONSTRUCTION OF RELIGION}

chief source of weakness and corruption in the modern world.

Though professional philosophers have professed to despise the philosophy of Nietzsche as that of a mere literary man, yet there can be no doubt that it was deeply rooted in the philosophical tendencies of the nineteenth century. The individualistic, naturalistic, and materialistic tendencies of that philosophy all found expression in Nietzsche. In him we see the worship of the natural man, of freedom as an end in itself, of the superior individual as the only value worth considering, as well as the worship of power. The truth is that the philosophy of the nineteenth century was rooted in Greek philosophy, and scarcely more than Greek philosophy did it escape from the traditional point of view and valuations of barbarism. The best of the nineteenth-century philosophical thinkers, to be sure, sought strenuously to transcend these, and to put philosophy upon a truly social and humanitarian basis; ${ }^{1}$ but the more popular nineteenth-century philosophy remained enamoured of pleasure and power as the chief values of life. It sought for a standard of right in these abstractions and ignored the social life of man. It contended that the standard of right lay wholly within the individual, in his own happiness or self-development, and not in the interdependent life of all men. Such was the popular philosophy of the nineteenth century, and it is evident that it was more pagan than Christian. It made it impossible to discredit the predatory ethics of barbarism.

It may seem hazardous for one writing in the name of science to assert that much science of the nineteenth century was even more anti-social, more anti-humanitarian,

${ }^{1}$ E.g., T. H. Green, Friedrich Paulsen, Josiah Royce. 
and so, more anti-Christian, than its philosophy; but we believe that this will be the judgment even of social science in the future. There is, of course, the excuse that modern science is so recent in its development that it has not had time to become socialized. A great part of the science of the nineteenth century was, at any rate, socially negative in its attitude. ${ }^{1}$ It not only held that there was nothing in religion of serious scientific concern, but that the spiritual aspects of human life were outside of scientific reality; ${ }^{2}$ and even in many cases it held that there could be no social science at all. Science, that is accurate, systematized knowledge it was held, could alone concern itself with the material and the physical. If any social science existed it must rigorously exclude from its consideration the psychic or the spiritual, at least as having any real influence in human affairs. Everything must be interpreted as belonging to one big machine. That such a conception belongs to the infantile stage of scientific development needs hardly seriously to be argued. Children and savages, it is well known, are apt to take a similar view of things.

With such ignoring of the spiritual and the social, it is little surprising to know that nineteenth-century science only very late began serious attempts at the construction of socialized standards in morals and made no successful

1 For illustration, see Henry Adams, The Degradation of the Democratic Dogma, especially "A Letter to American Teachers of History." Refutation of this sort of science, so far as it attempted to base itself upon biological facts, will be found in Professor J. Arthur Thomson's System of Animate Nature and Professor William Patten's The Grand Strategy of Evolution: The Social Philosophy of a Biologist.

${ }^{2}$ Thus one of my colleagues, though himself a religious man, holds that science has no purpose except "the quantitative statement of objective facts." This not only precludes the consideration of the psychic as such, but limits the field of science in a way not warranted by its history nor by the nature of the scientific attitude of mind. See p. 3. 


\section{THE RECONSTRUCTION OF RELIGION}

attempt at all at the construction of an international morality. Science remained in the nineteenth century immersed in its beginning tasks, the exploration and understanding of physical nature, and scarcely arrived at seriously undertaking the exploration and understanding of human social life. Though there were many exceptions, it is fair on the whole to say that nineteenthcentury science was negative toward higher social values, and instead of tending to build up higher social standards and ideals, in many cases it actually tended to destroy these. If it had addressed itself properly to the great problems of human living together in our civilization, in the spirit of the service of mankind, the Great War would probably have been averted.

All of these spiritual tendencies of the nineteenth century naturally found expression in the universities in Europe and America. One should never forget that Nietzsche was a university professor, and that the apologists for Machiavelli and Nietzsche in Europe and America were chiefly men who held university chairs. These men were not confined to Germany, as so many would fain believe. There were von Treitschkes and Nietzsches of lesser renown in many universities of Western civilization. This, indeed, could not be otherwise, because institutions of learning, in free societies at least, are necessarily places where all the spiritual tendencies of the time come to a head, and where the decisive spiritual battles are fought. One can only regret, not the appearance of such thinkers in academic life, but rather only that they seemed to be, previous to the breaking out of the Great War, getting the upper hand, to such an extent, indeed, that in some university circles for a scientific man to express his belief in Christian social ideals was for him to be more or less discounted by 
his scientific colleagues. In many cases the universities of Western civilization thus became the chief centers of neo-paganism. In Germany this happened to be particularly true.

Even the Christian church itself became subtly affected by the pagan tendencies of the times. ${ }^{1}$ We do not refer to the growth of "worldiness" in the church (though "worldliness" is frequently only a euphemism for paganism), nor to the growth of negative criticism, but rather to the whole spirit developed by nineteenth-century Protestant Christianity. As one of the most enlightened religious thinkers of the present has said: "There grewup a conception of Christianity ... in principle largely self-centered and individualistic. The energies of Christians found sufficient outlet in the preparation of the individual for the life after death, and the winning of new candidates for the citizenship of the future kingdom. Not transformation of this world, but escape from it, became the Christian message; not social leadership, but protest the function of the church." 2

Alongside of this comparatively common unsocialized type of Christianity existed less common, even more unsocialized types, such as so-called Christian mysticism. Since to the true mystic God is the only reality, he has no interest in the present world. ${ }^{3}$ The mystic thus entirely inverts the Christian principle that the service of God must be sought in the service of man." Mysticism,

1 This in addition to the survival of pagan tendencies which we have already noted. (p. 86.)

'W. Adams Brown, Is Christianity Practicable?" pp. 25-26.

8 Ibid., p. 28.

- This is not true, of course, of those modified forms of mysticism in which the rational ethical elements of religion receive the main emphasis, as among the Quakers. Some forms of mysticism of this sort, indeed, approximate what we have called "positive Christianity." Thus the creed of Florence Nightingale: "I believe . . . in the service of man 


\section{THE RECONSTRUCTION OF RELIGION}

in this individualistic sense, belongs to paganism rather than to Christianity; yet it was rampant in pretty nearly all branches of the Christian church during the nineteenth century, greatly to the detriment of the church, because superficial thinkers took it to be one of the typical expressions of Christian religious life.

Even nineteenth-century humanitarianism itself became largely perverted by the pagan tendencies of the age. It set up the soft and effeminate view of life too often; it seemed to make the pleasure and happiness of individuals now living often its only concern. The barbaric standards of self-gratification and self-indulgence, rather than those of social conservation and social development, were all too frequently advocated in the name of humanitarian ideas. Thus the word in the minds of some became associated with hedonistic social ethics and with pampering social practices. It became opprobrious, therefore, to those who saw that right human living involved higher aims than mere relief from suffering and the accumulation of pleasant experiences.

Thus it is evident that pagan ideas and ideals of life in general lay behind the anti-Christian politics and antiChristian business of the nineteenth century. Our

being the service of God, the growing into a likeness with him by love, the being one with him at last, which is Heaven"-would appeal to many not as "mysticism," but as "the essence of common sense." It must be admitted that mysticism is a relative matter, as there is normally an element of mysticism in all religion, as was granted in Chapter I. It is only when the mystic element is ascendant that there is danger of irrationality and anti-social tendencies. Subordinated to rationality, it is as harmless in religion as the sense of mystery is in science. The terms "mystic" and "mysticism" should therefore be reserved for those cases in which the supremacy of intelligence and reason is denied. For discussions of the place of mysticism in religion, see the works of Hocking and Leuba above mentioned. For a careful, brief survey, see Coe, The Psychology of Religion, Chapter XVI. 
analysis might go into further details to show how the taint of pagan barbarism clung to practically everything in nineteenth-century civilization; but our object has been merely to show that that civilization was dominantly nonChristian in character, a conclusion which is a mere truism to those who know both what the Christian ideal of life is, and what nineteenth-century civilization was. With scientific fairness we can say that the ruling classes in Europe and America in the nineteenth century accepted a "conventional" Christianity, but that they rarely permitted it to interfere with the "mores" which controlled the practical affairs of their life. ${ }^{1}$ They found it vastly easier to be conventional Christians than to be genuine followers of Jesus. In general they were careful not to let Christianity disturb the established order. And there is surely no evidence to show that as yet our civilization has changed its character. ${ }^{2}$ We are still trying to

${ }^{1}$ While perhaps not unbiased, the report of the Japanese Commission in 1919, which investigated religious conditions in the United States, that "there is little evidence that the Christian religion is regarded as important by most of the people," deserves consideration, as it tells us how our civilization appears to enlightened nonChristians.

- In a remarkable manifesto issued in May, 1921, by such leaders of religious thought in Great Britain as Dr. L. P. Jacks, Dr. W. B. Selbie, Dr. John Clifford, and Dr. A. E. Garvie the utmost apprehension is still expressed. If to American readers their tone seems too pessimistic, it should be borne in mind that British thinkers stand nearer to the hard problems of our civilization than we do. The manifesto in part follows: "No lover of mankind or of progress, no student of religion, of morals, or of economics, can regard the present trend of affairs without feelings of great anxiety. Civilization itself seems to be on the wane. ... The nations are filled with mistrust and antipathy for each other, the classes have rarely been so antagonistic, while the relation of individual to individual has seldom been so frankly selfish.

"The vast destruction of life by war and the acute suffering which the war created seem to have largely destroyed human sympathy. ... Never was greater need of all those qualities which make the race human, and never did they appear to be less manifest.

"It is becoming increasingly evident that the world has taken a 
build our world upon the rotten foundations laid by the nineteenth century!

However, it is, of course, true that in the nineteenth century we find the dawn of a better civilization breaking practically everywhere. This was true even of Germany, where, in spite of militarism, Machiavellian state craft, and neo-pagan philosophy and literature, there were philosophers, educators, religious workers, and political leaders who stood firmly by humanitarian ideals. Indeed, it was only in the last few decades previous to the beginning of the Great War, that marked retrogression in certain circles and classes toward pagan and barbarous ideals of life took place in Western civilization. But this rekindling of paganism found a world poorly organized to resist its spread. Everywhere practically the forces of good were disorganized. Good men emphasized their differences, and instead of pulling together, pulled apart. This was especially true of the Christian church; but it was also true of the humanitarian forces outside of the church. Even among the most advanced social idealists there was such confusion and disagreement, oftentimes even with respect to fundamental principles, that they could not work effectively together. On the other hand,

wrong turn, which, if persisted in, may lead to the destruction of civilization."

In a similar spirit Professor L. T. Hobhouse expresses himself in the July, 1921, issue of The Sociological Review (p. 125) : "The question of the survival of civilization, which month by month becomes more doubtful and more urgent, does not depend upon political institutions alone. Fundamentally, it is a question of the available amount of moral wisdom in mankind."

One must add that the Treaty of Versailles and the lack of concern shown by the United States and the Allies for the rehabilitation of Russia and Germany are further grounds for apprehension. On the other hand, the seeming success of the Conference on the Limitation of Armament at Washington is ground for hope. Even if the Conference is successful, however, it is well to remember that it is "only the first motion toward the first step toward real disarmament." 
the sinister forces readily and easily combined, until their power much overmatched the forces which made for peace, good will, and solidarity among men. The result was the long swing back toward barbarism among the nations of Christendom which finally became visible in the Great War, and in the breaking out of civil strife between classes in some nations.

Now this recrudescence of barbarism shows conclusively enough that our civilization can no longer remain half pagan and half Christian. It must soon become one or the other. We have come to the parting of the ways. Unless the world becomes speedily Christian, it is bound to become speedily pagan. We cannot tolerate pagan standards in business, in politics, in education, in art, literature and science without coming to repudiate the Christian ideal of life altogether. The half-and-half standards of our previous civilization will no longer work in the complex and tremendously dynamic social world of the present. If it be said that our civilization has always been half pagan and half Christian and that it will doubtless continue to be so, it must be said in reply that the events of the last few years and our present situation show that it cannot remain so. "Nothing can prevent mankind," says a thoughtful writer, "from sinking beneath the tremendous temptations due to modern wealth and power save the creation of a strong religious life which shall lead us to consecrate our control over nature to the process of bringing in the Kingdom of God." 1 Modern physical science has now put such terrible agencies of destruction in the hands of man that good will is needed as never before if men are not mutually to destroy one another. We dare no longer live together upon the old basis of a

${ }^{1}$ G. B. Smith, Social Idealism and the Changing Theology, p. 153. 


\section{THE RECONSTRUCTION OF RELIGION}

balance of power and of selfish interests. In the next war, we are told by experts, tanks as large as battleships will crush out our cities, while poison gases will stifle whole communities within a few hours. Mankind must end war or war will end civilization. ${ }^{1}$

Yet war cannot come to an end until men get rid of their illusions that classes or nations can live together in peace without good will and justice. Only the restoration of the ideals of good will, justice, and brotherhood within nations, moreover, can prevent the breaking out of interminable civil strife among classes, such as Russia has presented to our gaze. Just as within the American union, therefore, there came a time when the nation could no longer exist half slave and half free, so in Western civilization the time has arrived when we can no longer remain half pagan and half Christian. Either we must proceed to develop our civilization speedily along the lines of the pattern ideas of justice, brotherhood, and good will of the Christianity of the Gospels, or the world will go back to barbarism. All other ideals of life have been tried and have failed.

There is need, therefore, at the present moment of a stalwart religion, a Christianity which shall bend its energies to making our whole civilization conform to the Christian ideal of life. [Such a Christianity must be necessarily non-theological, because theology remains a realm of speculation and of disputation and divides rather than unites men. Such a Christianity must be thoroughly social; it must consider none of the great ficlds of the social activity of mankind alien to its interest. Such a Christianity must base itself upon the facts of life, and ally itself with humanitarian science.

${ }^{1}$ See Irwin, The Next War. An Appeal to Common Sense. 


\section{CHAPTER V}

POSITIVE CHRISTIANITY THE RELIGION OF HUMANITY

THe fourth thing needed for the reconstruction of religion, so that it shall be adapted to the requirements of modern life, is that religion be based upon facts and so brought into harmony with positive science. As we have already pointed out, the outstanding and dominating thing in modern civilization is science. Much of the science of the present, however, is partial, incomplete, and not based upon facts, not at least upon all of the facts. When we speak of a positive religion which shall harmonize with positive science we mean a religion which is based not upon a few of the facts of man's life-say, the physical-but upon all of the facts. A religion which has respect to all the facts of the total life of mankind will be in harmony with the spirit of true science. When we have a religion which is truly positive and a science which is the same, there will be no longer any need of reconciling the two. The former will be simply the projection and universalization of the values found in the latter.

The word "positive" we use in the same sense as used by Comte and by modern science in general, meaning, "founded upon fact," not upon mere opinions or speculation. A positive religion, therefore, means one based upon experience, upon objective realities. It means, accordingly, something socially constructive, and affirmative rather than merely negative. ( It is not a religion of negations or of mere prohibitions, but is practical, dealing with the actual facts of human life and experience as it 


\section{THE RECONSTRUCTION OF RELIGION}

finds them. It is not a religion of doubts, accordingly, but of affirmations. It is, in short, a religion of sanity, insisting that man shall build his faith in his world and his ideal of life, his universal values, upon all the facts of his experience. And it insists that this experience is a social experience and that his ideal must, accordingly, be a social ideal, his values, social values.

Christianity if it is to survive must become a positive religion in the sense just indicated. 'It must pass out of the theological and speculative stage into the positive and social stage. It must be purged of its mythological elements. When Comte in the later years of his life came to appreciate the importance of religion in the social life of man, seeing that social reconstruction was impossible without enlisting on its side man's emotions, instincts, and will, that is, impossible without the essentially religious attitude of mind, he proposed a "Religion of Humanity." The religion which Comte established was essentially Christianity minus its theology. Comte accepted without qualification the essential ethics of Christianity. The highest command of his new religion was to be the law of service- "live for others"-which, as he himself recognized, was manifestly but stating in modern vernacular the Christian law of service. It is strange, indeed, that Comte did not perceive that the Christianity of the Gospels was in accord with the Religion of Humanity which he sought to set up." But Christianity in Comte's mind was synonymous with the ecclesiastical and theological systems of his day, and it was, accordingly, impossible for him to see in Christianity the Religion of Humanity which he sought. He was unable to enceive that Christianity itself might enter into the positive stage and become a real Religion of Humanity. 
Comte's Religion of Humanity failed to take root and is now all but extinct. But organized Christianity, in the countries where it has had the freest development, in contact with the social life on the one hand, and science and facts on the other, has steadily progressed toward the positive stage. It has more and more unfolded its latent capacities to become that true religion of humanity which Comte saw to be necessary to bring about any real and lasting social progress. As evidence of the progress of present Christianity toward the positive and humanitarian stage of development, the comments of two European-born observers on the development of religion in the United States are interesting. Says Henry Bargy in his La Religion dans la Société aux États-Unis: ${ }^{1}$

"As dogma has never seemed to Americans the vital part of religion, so has agreement upon dogma never seemed to them the condition of moral unity; they think that people may have the same country without having the same theology. They make fraternity, the actual form of which is social solidarity, the essence of Christianity. The moral unity for which they strive under the name of Christian unity is only the co-operation of all for the increased establishment of fraternity and solidarity. High above sects whose diversity seems a matter of indifference to them they organize a religion which pervades society throughout its length and breadth, and tends toward being only a social spirit touched by the evangelical feeling. At the time of the Puritans it was a religion of race, as it had been with the Hebrews a religion of tribe; in proportion as the conception of the race enlarges so as to

${ }^{1}$ Pp. XVI-XVIII. This book, though it presents inspiring ideals rather than a careful survey, deserves translation into English (Librairie Armand Colin, Paris, 1902.) 
extend to the entire human race, it becomes a religion of humanity. All the groups from all the points of thought find a basis of unity in the homage paid to human virtue and human progress. Positivism has consummated the moral unity of the nation. ...

"This moral unity is indeed a religious unity and a Christian unity; this positivism is a Christian positivism. American humanism has received from Christianity all the traditional, sentimental, and poetical elements which distinguish a religion from a philosophy. American positivism is only a Christianity which has evolved. As the first colonists, in their zeal, had made God the servitor of their new-born society, and placed religion at the service of the ideal humanity which they believed themselves to be organizing, contemporary humanitarian philosophy has encountered nothing contrary to it in the churches of the United States; it has made use of them as frames all ready for it to take form in. "The American religion may be ealled a Christian positivism, or a positive Christianity. 'It has received from the past the traditional and the evangelical spirit. Traditional, it preserves the names and the forms of the churches even when it changes their eustoms; it develops them from within. Evangelical, it keeps the figure of Christ before all, even when it does not recognize his divinity. American positivism, so akin to that of Auguste Comte that Channing, after 1830, looked to France for the religion of the future, is distinguished for its religious character, and is conciliatory, not combative. In their tolerance for the past, from which they disengage the future, $\Lambda$ mericans deserve the title 'positivist' more than did Comte, since they not only neglect the discussion of metaphysics, but ignore them. While the disciples of Comte have been able to produce only a parody of religion, American positivism 
has its temples, clergy, followers, which are no other than those of Christian churches. One may conceive a positivism with a God, as one may conceive a republic with a king; it is sufficient that the king be the servant of the people, and God, that of humanity."

In a similar spirit a former student of the author, writing of the American church from the point of view of the Jewish immigrant, says:

"I had expected mysticism and had found common sense. In my half knowledge of the church on the one hand and the American ideal on the other, I had looked for another of those hypocritical exhibitions of which I had seen many in my native country, where men practised one thing and pretended belief in the opposite. I had looked for humbug and had found the most perfect honesty. I had looked for self contradictions, for solemn professions of faith in far-away impracticable abstractions, for pretenses of submission to an ideal of humility and non-resistance and supineness, and I had found what? A clear-eyed, level-headed, sane body of principles such as a practical modern man could believe in. I had stumbled upon a discovery. For the first time in human history, as far as I knew, a people had evolved a creed that was in harmony with their lives and with their ambitions. ...

"The American religion, I saw, was a vital, practical religion. If it was ethical, it was concretely so, and cared nothing about the philosophical abstractions underlying good and evil. It asked people to be good in order that' the good they craved might come to them. . . ."1

These generous comments of disinterested observers of ${ }^{1}$ M. E. Ravage in The Century, January, 1918. 
our religious life are, however, more favorable than the facts altogether warrant. If the picture were entirely true, there would be no need of this book. There is still, even in the United States, much religion of the narrow, ecclesiastical, and theological type, unadapted to the requirements of modern life; and in Western civilization, as a whole, organized Christianity is very far indeed from the socialized and positive type. While a humanized and socialized Christianity has been gradually rising during the last generation among the leading nations of Europe and America, organized Christianity, as yet, is only beginning to enter upon the positive stage. It is our pur. pose to show how the development in this direction can be hastened, how Christianity may become such a religion of humanity as will subordinate the socially negative elements in our culture and establish humanitarian civilization upon a firm basis.

A word of caution is necessary here. Positive religion does not imply the agnostic and negative attitude which Comte maintained toward many of the essential elements in religious life. These agnostic and negative elements in Comte's teachings were the outcome of the spirit of his age and of his particular environment, rather than any necessary result of a positive, objective, scientific attitude toward religion. Absolute agnosticism, or a negative attitude toward ultimate reality which must be the supreme object of religion, so far from being consistent with the positive and scientific attitude of mind, is wholly inconsistent with it. ${ }^{1}$ Comte, in other words, made the great mistake of thinking that religion could be an entirely subjective affair, and that man might take a nega-

1 The positive attitude in science and philosophy implies, not a subjectivism, as some critics have mistakenly maintained, but rather a critical realism. 
tive attitude toward his universe but retain a positive attitude toward himself and his own destiny. This, as Caird has pointed out in his criticism of Comte, ${ }^{1}$ was undoubtedly a contradiction in terms. A purely subjective religion is an absurdity. ${ }^{2}$ Such a religion would be very far from a positive religion, a religion based upon all of the facts of human experience. No such subjective religion is here proposed. Rather our aim will be to show that a social and positive Christianity, will be a Christianity robbed of none of its essential elements, though reduced to its purest form; and that such a Christianity is the only religion which will meet the needs of the modern world.

Yet another word of caution is needed on the other side. While Comte was wrong in his subjectivism and agnosticism, yet all must admit that he was essentially right in saying that it is psychologically impossible for man to worship anything but the highest and best which he finds in himself. Religion, in other words, as we have already pointed out, must draw all of its values from the social life of man, for psychologically it has no other source $\lambda$ from which to draw them. This is wholly the case with Christianity. Its doctrines of the divine fatherhood, of human brotherhood, of love, of service, of self-sacrifice for the sake of service, are all manifestly drawn from the higher experiences and values of social life. ${ }^{3}$ What man must worship, therefore, in religion, as Comte insisted, are those ideals of character and conduct, of personality and society, which he has gotten from his social

1 The Social Philosophy of Comte, especially pp. 163-170.

- The religious consciousness, as has often been pointed out, demands objectivity quite as much as the scientific consciousness.

- See Chapter II, pp. 39-42. 


\section{THE RECONSTRUCTION OF RELIGION}

1

life. But these ideals cannot be worshipped as abstract, subjective values; they must be projected into the universe and found embodied in concrete living personalities. Religion is undermined, for reasons which we shall soon see, whenever this projection and universalization of social values is denied to the religious attitude of mind. The negative attitude toward life and the universe which we find often in materialistic speculation and in agnostic opinion is necessarily deadly to religion. Religion has a right to attack, in the name of humanity, such subjective metaphysics and socially negative doctrines which sometimes masquerade under the name of science; and in doing so religion performs a real service to science, because such doctrines are not only unproved, but are not in accord with what are the seeming facts of human experience. But positive religion does not deny that it derives its concepts and values from human experience, even though it projects and universalizes them. Thus it escapes from negative metaphysics on the one hand and from any attempt to erect a metaphysical system on the other hand. It simply bases itself upon the facts and needs of man's social life, universalizing social values so that they will come to individual consciousness in the intensest way and thus aid in making the more difficult adjustments required of the individual in his social relationships.

The general attitude of positive religion is, then, no different from positive science, except that it carries the process of universalization a step further on the side of human values. Its attitude is the frank, open-minded attitude of a progressive social idealism, that of a learner rather than that of a dogmatist. It is not on the defensive as regards positive science, a science based on facts rather than on speculations. The truths of science, if they are truths, positive religion holds will do religion 
good rather than harm in the long run. Indeed, they will be the very means by which religious ends of the right sort can be realized. For a truly positive science will also take into full account all of the facts and needs of man's life. It will also be humanitarian, not less than positive religion, and between humanitarian science and humanitarian religion there can be no conflict. Both will join hands for the conquest of nature and the redemption of humanity.

What then will be the distinguishing features of Chris-' tianity when it has reached the positive stage of development? In brief, it will become "transfused with the spirit and transformed by the method of modern science." But what does this mean? It means first of all that positive Christianity will subordinate theological and metaphysical questions. This does not mean that it will take a wholly negative attitude, as we have already said, toward these constructions of the human intellect. Both are doubtless necessary rational disciplines, necessary intellectual tasks which the human mind must essay from time to time as it sees its fund of knowledge growing upon which to base inferences in regard to ultimate reality. ${ }^{1}$ But positive Christianity will not stress the theological side of religion as the vital thing in the religious life; rather it will minimize it. The world is rapidly learning that it can get along very well with a much smaller minimum of theology than it had formerly supposed, and perhaps it will soon discover that what is regarded at the present time as the minimum may be still further re-

1 For a recent attempt at a rational theology which dodges none of the issues involved and which recognizes frankly the results of modern science, see Professor E. W. Lyman's book, The Experience of God in Modern Life. 
duced. We shall try to point out later what appears to be the requisite minimum of theological beliefs necessary even in a positive Christianity.

The second characteristic of positive Christianity is that it will be concretely ethical. It will be social, in other words, rather than theological. St will throw the emphasis in religion where Jesus threw it, upon the relations of men to one another, rather than upon theological doctrine. ${ }^{1}$ It will insist, as Jesus insisted, that religion and morality are not separable. Religion, as the right attitude toward universal reality, includes morality, the right attitude toward man. Religion is simply morality raised to its highest power, or universalized morality, while morality in the common acceptance of the term should be religion brought down to the practical, every day relations between men. This practical identification of religion and ethics will be a chief feature of socialized or positive Christianity, for as soon as ethics is allowed to become divorced from religion, as we have seen, it ceases to have power over the springs of character and conduct in the mass of individuals. The social efficiency and strength of any religion has always been directly proportional to its power to enlist the religious nature of man upon the side of ethical ideals. This has always been the peculiar strength of historical Christianity in its periods of highest development. The subordination of theological questions to ethical questions in the teachings of Jesus was not an accident. It was rather the mark of the highest possible evolution of religion. [ In this respect as in others positive Christianity will be in a sense a return to the religion of Jesus.

${ }^{2}$ It is said upon good authority that a single page will hold all that Jesus said upon such subjects as the soul, death, immortality, and eternity. 
A third characteristic of positive Christianity is that it will be collective rather than individualistic It will emphasize the relations of men to one another in their concrete social life, the redeemod community, the redeemed world, the kingdom of God" upon earth, rather than the redemption of individual souls.) An ethical Christianity must necessarily make the community, indeed, as much its concern as the individual, since the conditions of the community surely determine in greater or less degree the individual life. The world is the subject of redemption for positive Christianity. There is every warrant for believing that this was the attitude of Jesus. The kingdom of God which he announced he had come to establish is essentially a social conception, meaning an order of human society. ${ }^{1}$

This does not mean, of course, that the individual is to be neglected by positive Christianity. On the contrary, a redeemed society presupposes redeemed individuals. As humanity is not something apart from indiviauals, it can only be saved through saving individuals. But positive Christianity will recognize that man leads a collective life and that the conditions of that life make or mar the character of individuals. Individualistic methods of helping individuals will be preserved by positive Christianity, for they are indispensable in any right social life. It is the humane, the brotherly touch which does most to help under all conditions. Christianity can never neglect the personal work of individuals for individuals; but as it becomes more positive, it will see that the larger economic, political, and cultural conditions even more need to be controlled if the world is to be redeemed, to be made safe

1 This is not to deny, of course, that this expression also implied an inner, subjective, personal state. As a spiritual conception, it necessarily had both its personal and social sides. See further discussion on page 178.
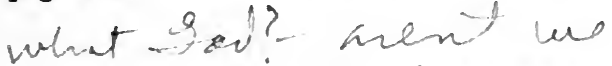

of $x$ ind 
for Christian living. While on the one hand positive Christianity will reaffirm the preciousness of every individual soul, the idea that every individual should bo regarded as an end in himself, it will lay its chief emphasis upon the need of creating an ideal human society, a kingdom of God upon earth.

A fourth characteristic of positive Christianity is that it will be active toward all human things rather than merely contemplative. A Christianity which is mere belief or faith cannot possibly be regarded as positive Christianity. If religion is to be ethical and social in character it must also be active. Positive Christianity must be in a very true sense a militant movement, directed against all the forces that oppress and degrade men. It is the moral substitute for war. It can have no patience with the idea that there is anything not subject to the Christian ideal of life. Positive Christianity is distinctly, therefore, a radical, even a revolutionary movement, not in the sense, of course, that it will rely upon force, or that it hopes to usher in the millennium by some sudden transformation of the social order. But it is revolutionary in its ideal of life, and it must be aggressive in its methods of dealing with evils that beset our social life. Positive Christianity can be no milk and water affair. Just as Jesus did not contemplate that love might mean merely a passive good will, so positive Christianity will insist that the fruit of the Christian ideal is aggressive effort to suppress the evil forces in our civilization, and to establish a society in which the ideals of justice, of fraternity, and of mutual service are realized.

It follows from this that a fifth characteristic of positive Christianity is that it will be constructive and affirmative rather than merely negative. It will not be so much a series of prohibitions as a definite positive program for 
both individual and social life. It may have at times to destroy in order to make a place for the good, but it will destroy only for the sake of upbuilding something positive. It will seek to replace the negative ethics of barbarism and of early civilization by a constructive program of social betterment. T This again represents the attitude of Jesus. The negative attitude of the Old Testament he replaced by the positive, constructive social morality of the New. JPositive Christianity cannot be an affair of "taboos."

The sixth characteristic of positive Christianity is that it will be co-operative in its spirit. It will recognize the fundamental sociological truth that ten men working together can accomplish what one hundred cannot accomplish working separately. It will believe in organized effort rather than in merely individualistic right living. The church, therefore, in positive Christianity must take a place of commanding importance, not as an end in itself, but as an indispensable means for realizing the ends of a social Christianity. The church, as the organized followers of Jesus' teaching, must enlist the enthusiastic service and loyalty of all who believe in the Christian ideal of life. This in no way places the church above criticism, but on the contrary renders it liable to the most searching criticism as to its efficiency as an instrument for the establishment among men of the Christian ideal. The church must be regarded strictly as a means, not as an end. Nevertheless, the idea of following the teachings of Jesus in secret and without the fullest co-operation with all those who believe in those teachings, is repugnant to the idea of a social and positive Christianity. Religion cannot be a private, individualistic affair if it is social and scientific. It will not hide itself, but will undertake 
through organized effort along every fruitful line of endeavor the redemption of mankind.

But what shall be the attitude of positive Christianity toward the essential beliefs of all higher religions, the belief in God, the belief in immortality, and the belief in the reality of $\sin$ and of salvation from $\sin$ ? The reply is that a positive Christianity will reaffirm these beliefs as a part of the universal religious consciousness of mankind. They are not the peculiar beliefs of Christianity, but all higher religions have these beliefs in some form. What form will they take, then, in positive Christianity? Will positive Christianity, like Comte, accept as its Supreme Being, humanity itself ?

As we have already pointed out, no religion can be subjective and at the same time positive; and to find in humanity the supreme reality, into harmony with which man must seek to come, is a species of subjectivism. ${ }^{1}$ It,

${ }^{2}$ Such religious subjectivism characterizes not only the Comtean positivists, but also the extreme pragmatists and some other schools at the present time. Thus Dr. A. E. Haydon in an article on "The Theological Trend of Pragmatism" (American Journal of Theology, October, 1919, p. 408) says: "Religion becomes enthusiasm for social ideals. . . . Religion will still persist. . . . Its cult will be the web of civilization." So also Mr. H. G. Wells in God, the Invisible King (p. 61): "He is the undying human memory, the increasing human will." Dr. G. Stanley Hall also declares (Morale, the Supreme Standard of Life and Conduct, p. 354): "Belief in God . . . must be subjectified." But many of these subjectivists in religion do not hold consistently to their subjectivism. Thus Dr. Hall says (op. cit. p. 356): "The supreme object of worship and service is the power, that in the beginning started the course of evolution and in the end became the power that makes for righteousness." Even Dr. Haydon in a later article (Journal of Religion, Vol. I, p. 196) speaks of religion as "just the way we orient ourselves to cosmic realities in the interests of our larger life." We safely conclude with Professor Brightman (Journal of Religion, Vol. I, p. 366) that "the need for objectivity is at the basis of science, philosophy, and religion." For further discussion, see the articles by Professors Ames and Hocking in the September, 1921, Journal of Religion (Vol. I, pp. 462-496). 
indeed, denies the very purpose of religion, which is harmonious adaptation to all of the conditions of human life. To say that humanity is the sole object of religious veneration, worship, and love is like saying that humanity needs merely to adapt itself to itself. It divorces religion absolutely from science. Our religion cannot teach one thing and our science another; and if there is anything which modern science clearly teaches, it is that man is a part of nature, a part of a system of things immensely transcending himself, which has produced him and made possible all of his works. Man does not cease to stand in the midst of nature because he is, as an individual, the product largely of his civilization. The religious consciousness no more than the scientific consciousness can stop with man and his works. In a certain sense, man is incurably a nature worshipper; that is, his reverence, his affection, his valuations rise from man to the ultimate reality which lies behind both man and physical nature. This is the logical as well as the instinctive thing for man to do; for if religion is an organ of adaptation, it must have reference both to man and to the universe in which he lives, moves, and has his being. ${ }^{1}$

Indeed, in a certain sense, the universe must always loom larger in the religious consciousness than man, just as it does in the scientific consciousness. Not the self-sufficiency

1 "In naturalistic thought," said the late Professor Bowne, "nature is the rival of God. Nature does a great many things and God does the rest. Traditional religious thought has shared the same view, and thus nature was continually threatening to displace God. God was not to be appealed to until nature had been shown to be inadequate. Hence the dismay in popular religious thought at each new extension of the realm of law, every such extension being regarded as subtracted from the control of God. But this dismay vanishes entirely when it is seen that God is the 'Infinite and Eternal Energy from which all things proceed'; or that, in Pauline phrase, 'in Him we live and move and have our being.' Now, nature is no rival of God, but the form of his manifestation."-Hibbert Journal, July, 1910, p. 888. 


\section{THE RECONSTRUCTION OF RELIGION}

of man, but the sufficiency of God is the real basis of religion. Religion demands a reality beyond man, to which not only the religious consciousness functions as a means of adjustment, but whose law and order compels adjustment. It demands a universe of law, not less than science does, a universe whose processes bring the foolishness and wickedness of men to naught. Where science, however, sees only the laws of physical necessity, religion sees a moral order, to which the life of man must conform itself, if it is to be in harmony with the infinite.

To be sure, the superficial scientific thinking of the nineteenth century often went out of its way to deny that there were any moral implications in the law and order of the universe. It pointed to the flood, to the earthquake, to the tornado, to the struggle for existence, as proof positive of the non-morality of nature and of the power which lies behind physical nature. Such views were, of course, based upon the assumption that the moral is synonymous with the pleasant and the agreeable. To such thinking there was no place for religion as a means of adapting man to the conditions of his life, of putting him in harmony with his universe. The moral according to this view is something not to be learned by careful thinking, but was immediately known by the subjective reactions of experience.

Such views of religion and morality are, of course, not in keeping with the conclusions of scientific research; and along with such views must vanish our conception of a non-moral universe. ${ }^{1}$ The moral order to which human

${ }^{1}$ Says Conklin (The Direction of Human Evolution, p. 228): "The possibilities are almost infinity to one against the conclusion that the order of nature, the fitness of environment, and the course of progressive evolution with all its marvellous adaptations are all the results of blind chance. . . In short, science reveals to us a universe of ends as well as of means, of teleology as well as of mechanism, and in this it agree with the teachings of philosophy and religion." 
living must conform is after all but a segment of the cosmic order. The laws of human living together are no less a part of the laws of the universe than the laws of physics or chemistry. And these laws of human living together, or rather the perception of them, is what gives rise to human morality. The assumption of all sane religious thinking must be, accordingly, that "only man is vile." 1 Otherwise, indeed, a redemptive religion would be the most useless thing in the world. (If the universe is "vile," there is little need of a religious consciousness in man to adjust himself to it.

Without destroying religion, man cannot, then, believe that the universe is a "fool's house" which will bring his highest aspirations and his best endearors to naught. Man must believe that there is a meaning in existence and in the system of things, and that that meaning, while he cannot fully comprehend it, yet in part he does apprehend. He must believe that the universe is not alien to himself, if he is to have any basis upon which to adjust himself to life and to the ultimate reality which surrounds him. Nor does science in any way contradict or refute this reasonable faith. Science itself shows that man is a product of the universe, and to ask any one to believe that the universe is absolutely different from man is to deny that principle of continuity upon which science builds itself. If there is a spiritual element in man, it cannot have come out of nothing; neither can it be greater in man than in the universe, for that would be

1 The philosophy of the eighteenth century was wont to debate the question whether this was "the best of all possible worlds." From the hedonistic standpoint the debate was idle. But if the universe be judged as we have now learned to judge human institutions-from their educative effect upon the individual and the race-then something might still be said in favor of the affirmative. 
equivalent to saying that man is greater than the universe.

The negations of philosophical materialism are not, therefore, supported by the spirit and tendencies of modern science. While science may be far from offering the full measure of support to man's religious life which we may wish, yet it is very far from destroying a reasonable faith in the system of things. On the contrary, in its investigations of nature it is coming slowly but surely to the perception of a Creative Evolution, which is imminent in all the processes of nature. ${ }^{1}$ It is coming, in other words, to recognize that from the standpoint of man there is an ascending energy in the universe; and this is, after all, the substance of all rational religious faith, that back of man and his works is an ultimate reality which makes human life, not an accident and meaningless in the scheme of things, but the supreme expression of an infinite reality. ${ }^{2}$ Man's projection of his values into the universe in his religious attitudes has, therefore, a rational as well as an emotional basis, and it is scarcely probable that any religion based upon science will deny this; for to deny it means to destroy that common sense which is the basis of both sound science and rational religion, and to plunge

${ }^{1}$ Says Professor Hohhouse in his remarkable work, Development and Purpose, which perhaps presents more cogently than any other book the modern scientific argument for theism, though it seems little known to most theologians: "It is submitted, not in the least as a matter of faith, but as a sound working hypothesis, that the evolutionary process can be best understood as the effect of a purpose slowly working itself out under limiting conditions." (p. 24.) These "limiting conditions," Professor Lyman points out rightly (op. cit. p. 130) are those inherent in the nature of a developmental process, not extraneous cireumstances.

2 "If a purpose runs through the world-whole, there is a Mind of which the world purpose is the object."-Hobhouse (op. cit. p. 365). "If the world process is directed toward harmony, we legitimately infer a Mind at its center."-Hobhouse, The Rational Good, p. 230. 
into the confusions and absurdities of an absolute agnosticism.

But from another point of view one may say, with equal truth, that humanity looms larger in a rational religious consciousness than the universe at large. This is because man is the highest expression of the universe, and just as it would be insane on the part of science to try to understand the universe without taking man into account, so it would be insane on the part of religion to try to get a valuation of the universal reality without getting that valuation primarily through man. [ For man must ever be to both science and religion the highest revelation of the nature of the supreme reality. Indeed, in the practical religious consciousness it is the human element which plays the chief part; and this becomes increasingly so as religion becomes more ethical and social. It may be possible to have a dehumanized science which takes account of nothing except physical nature; but it is scarcely possible to have any longer a dehumanized religion. In this respect religion is more evolved than science. And it is characteristic of Christianity in particular that it throws its emphasis upon the human in religion rather than upon the non-human. It finds its revelation of the divine in the highest human. It finds, in other words, God in man, without denying, however, that God is in nature also.? It is the peculiar merit, then, of Christianity that it makes no dualism in the religious consciousness, by setting man off as something apart from the rest of the universe. It synthetizes objective and subjective religion. It reconciles the human and the cosmic, by finding the divine in both.

Says Dr. John Haynes Holmes (in Unity, January 13, 1921): "God is identified with humanity just as he is identified with nature; but he is also something more and infinitely greater than either of these worlds." This is precisely the doctrine of Christian theism. 


\section{THE RECONSTRUCTION OF RELIGION}

But the divine in man is not so much realized as something to be realized. It, thus, puts religion in the service of human evolution, and sets up a religion of humanity without destroying the religious attitude toward nature and the ultimate reality which lies behind nature. It makes religion primarily a means of human and social adjustment without making such adjustment a mere subjective matter within humanity or an adjustment to an ultimate negation.

Thus, positive Christianity has room for a very decided and positive belief in God, a God who manifests himself in nature, not only as creative evolution, but in human nature and in human society as the spirit leading towards all truth, all rightness, and all brotherhood. Indeed, one must say, with the French author whom we quoted at the beginning of this chapter, that not only "one may conceive a positivism with a God," but that one can conceive a truly positive religion in no other way. But the conception of God which positive religion arrives at is very different from many of the vagaries of speculative theology. It is more nearly in accord with the conception of God which Jesus held. When we turn to that conception in the pages of the first three Gospels, we find that it is the simple doctrine of the fatherhood of God. God, the ultimate reality, which has produced man and which is leading us upward and onward toward a better life with our fellows, toward a fuller realization of his will, stands in relation to us, according to Jesus, even as a loving father stands in relation to his children. Thus again, positive Christianity marks a return to the simplicity and humaneness of the thought of Jesus. Instead of fine-spun theological dogmas concerning God, it presents the simple 
faith that the creative force of the universe stands in a fatherly relation to us. ${ }^{1}$

Positive Christianity will be characterized, then, by a positive and unequivocal belief in the reign of God, in a moral order permeating the universe to which men must conform if they are to be successful in their living together. Just as men under a positive and scientific conception of nature know that in order to build bridges or sail ships successfully, they must understand and conform to the laws of physical nature, so under a positive conception of God men will know that in order to live rightly and happily, they must understand and conform to the laws of harmonious and successful living together. "Thus will positive Christianity replace arbitrary and mythological conceptions of God by a conception which is at once moral and in conformity to the facts of experience. The "Santa Claus conception of God," as a mysterious being who interferes with the ordinary course of nature to bestow special favors on those who seek to please him, will be replaced by the conception of a universal moral reality which permeates all existence, both physical and social, and which is the creator and preserver of all the good that man has known or can know. ${ }^{2}$ The autocratic conception of God, as a force outside of the universe who rules by arbitrary will both physical nature and human history, will be replaced by the conception of a spirit imminent in nature and in humanity which is gradually

${ }^{1}$ Compare the statement of Hobhouse (The Rational Good, p. 227): "Reality is an interconnected system which develops in time, the principle of rational harmony or love being the permanent underlying ground of development."

'As we have already pointed out (p. 124), the soundest religious tradition has never attributed the evils or maladjustments of human life to God. Says Professor Hobhouse: "It is an error of the religious mind to identify Reality as a whole (i.e., both good and evil) with God." (op. cit. p. 229.)

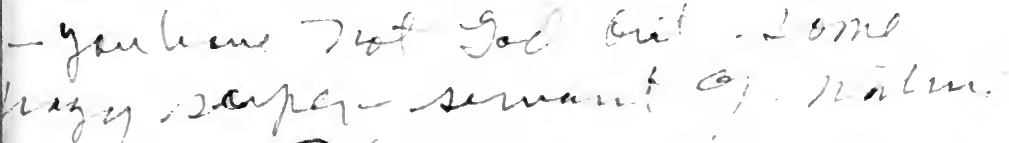


working out the supreme good in the form of an ideal society consisting of all humanity. The materialistic conception of God, if we may so call it, as a universe of meaningless play of energy, alien to the aspirations of man, will be replaced by a conception of God as realizing himself in the intelligence, welfare, and fraternity of all humanity. This is the God, as a modern religious thinker has happily said, "who strives within our striving, who kindles his flame in our intellect, sends the impact of his energy to make our will restless for righteousness, floods our subconscious mind with dreams and longings, and always urges the race on toward a higher combination of freedom and solidarity." And, we may add, this is the God whom Jesus speaks of as a loving father. Such a human, personal, and social conception of God may seem inadequate to the scientific mind, but if it is inadequate, it is surely inadequate by way of defect and not by way of excess. ${ }^{1}$

So, likewise, will positive Christianity reaffirm the belief in immortality. 7 Both sound science and rational religion forbid the belief that death ends all for human personality. Sociology and anthropology have united in showing the importance of the individual life, not only as a carrier of civilization, but as a modifier of civilization. It is individual lives which make up our human world, in other words, and these human lives, both physically and culturally, enter into the enduring life of humanity. In his religion of humanity Comte made much of this subjective immortality of the individual, as he

1 We need also to remember, as Professor Spaulding says (The Nero Rationalism, p. 517): "If God is personality, he is also more than personality, even as the moral situation among men is more than personality." In the same spirit Hobhouse rightly speaks of God as "super-personal." (op. cit. p. 228.) 
called it. According to him, all the good who have ever lived, live again in lives made possible and better because of their existence, while the bad are gradually but surely eliminated from the life of humanity. Since Comte, science has demonstrated this subjective immortality of the individual to be, we might almost say, an appalling fact-appalling because the elimination of bad influences is probably not so easy or so certain as Comte seemed to imply.

But is this "immortality of influence" the only immortality which positive Christianity will teach? No doubt the non-theologically minded Christian would in most cases at the present day be entirely satisfied if he could be sure that all the good which he tried to do would live on after him in the enduring life of humanity. $<$ The true Christian is not very much concerned about his personal fate in a world beyond death if he has lived rightly in the present world. The selfishness of that peculiar type of Christian who foregoes pleasures in this world in order that he may selfishly enjoy them in another life of longer duration does not appeal to him, and he recognizes it as quite alien to the spirit of Jesus. [ For Jesus concerned himself but little with the question of existence after death. Jesus simply took for granted the principle of continuity in the spiritual world. "In my father's house," he says, "there are many rooms, and if it were not so, I would have told you."

Yet, the belief in personal immortality cannot be dismissed by merely saying that the true Christian attitude in this matter is that of trust. A purely subjective immortality, such as Comte taught, is, after all, a contradiction in terms, and positive religion cannot remain satisfied with such a statement as a complete and reasonable religious faith. The life of humanity, science plainly 
teaches, is a process limited in time. A subjective immortality is, therefore, an immortality limited by the life of the race; and this raises the much bigger problem whether the life of humanity is itself a meaningless process. For a process which begins in a blank and ends in a blank is surely meaningless. The whole conception, therefore, of a subjective immortality without an objective correlate is antagonistic to a positive conception of the universe and of existence. The positive conception of God, which we have just stated, necessitates belief in immortality as an objective as well as a subjective fact. In what precise form this personal immortality is realized. will not concern positive Christianity. No scientific demonstration of the existence of the soul after the death of the body is necessary for the purpose of positive Christianity, and it will refuse to waste time in quest of proof of that which, if proved, would add nothing of value to the Christian life. Here again, then, positive Christianity is in harmony with the scientific spirit.

On the other hand, there is nothing in positive science which forbids a reasonable faith in personal immortality. Indeed, the evidence of positive science, so far as it has been able to get ascertained facts, seems to point to the conclusion that the principle of continuity reigns in the spiritual as well as in the physical realm; but no dogmatic conclusion has been reached by science, and this is, perhaps, well in the present stage of human development. The overemphasis upon personal immortality has frequently led to very unfortunate results in both religion and ethics. 5 Positive Christianity here as elsewhere will not attempt to set up dogmas upon uncertain foundations. In this matter, it will be content to affirm that the facts of science are not such as in any way to undermine a reasonable faith. It will avoid such attempts as have often 
been made by the church to depict the exact form in which personal immortality will be realized-attempts which all sane minds now see must be regarded as horrible or ludicrous caricatures of what a rational religious faith should be. Rather positive Christianity will, as we have already said, return in this matter to the simple, trustful, and affirmative attitude of Jesus, which is a sufficient foundation for the Christian life.

The attitude of positive Christianity towards sin and salvation will be unequivocal. The theological conception of $\sin$ is that it is rebellion against God. To this statement there can be no objection, if we remember that the service of God must consist in the service of humanity; therefore, rebellion against God is disloyalty to humanity. In simplest terms, sin is essentially selfishness; it is disloyalty to the claims of humanity, whether that humanity be our fellow human beings around us or those in distant lands or future ages. The conception of sin in positive Christianity, in other words, will be social and humanitarian. Sin will be the failure to recognize in all of one's fellow beings ends rather than mere means, or to act, as Kant said, so that the principle upon which one acts may be made into a universal law. But this is simply the Christianity of the Gospels. (In this case again positive Christianity will mean a return to the simple teachings of Jesus. ] The elaborate definitions of sin formulated by the creeds of the church will be thrown into the discard; but sin will not become, on that account, a less direfully significant fact in the religious life. Because sin is disloyalty to humanity, makes it no less rebellion against God and robs it of none of its terror or degradation to the true Christian mind.

The true Christian conception of salvation is that it is
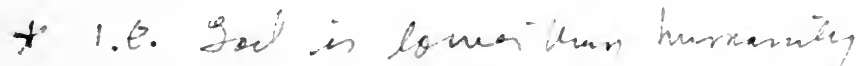


\section{THE RECONSTRUCTION OF RELIGION}

salvation from sin. This is the conception of the Gospels, but in the theological ages of the Christian church, salvation was often represented to mean, essentially, escape from punishment and assurance of bliss in a life beyond the grave. Thus, the whole conception of salvation was degraded to a refined sort of selfishness and otherworldliness. Positive Christianity will furnish a social conception of salvation in contrast to the medieval theological notions which have prevailed down to the present. It will not deny that human souls may be lost and in torment on account of sin; for that would be to deny an obvious fact of moral and religious experience. But it will emphasize that salvation means, not only deliverance from sin, but entrance into the joy of a life of love, of service, and of right relations with one's fellow men, and of a consequent right attitude toward God LIt will point out that for the individual, salvation consists, essentially, in identifying himself with the highest aspirations and welfare of his race. Actively, salvation will reveal itself by participation in all those movements and activities which are designed to redeem humanity. For groups of individuals, salvation will consist in accepting the spirit of Jesus, the spirit of seeking to serve God through the service of humanity. (Such groups as the church and the family, and, possibly, also the state when it shall become Christian, are the necessary and natural media by which individuals are saved; and hence positive Christianity will preach a salvation for groups as well as for individuals. For ultimately it seeks a redeemed world not less than redeemed individuals.

But it may be said that the crucial question has not yet been answered. What is the attitude of positive Christianity toward Jesus? Does it accept his claims, and is it 
in accord with the tradition of the Christian church? The answer, again, is unequivocal. [Positive Christianity will accept Jesus for what he claimed to be himself,] especially as his words are reported in the first three Gospels; but it will not accept what theologians have claimed him to be. Theological disputation, it is almost notorious, has obscured the simple and sublime figure of the Gospels. ${ }^{1}$ Scarcely any two theologians have agreed in regard to their claims as to Jesus, and certainly no two Christian sects. It is time surely that the Christian church should emphasize what Jesus said of himself, and not what men have said of him. The historical credibility of the main features of the Gospel story seem beyond reasonable doubt. $^{2}$ (Indeed, the principles of sociology and anthropology are such that even though we had no supporting documents from the early Christian centuries, the credibility of the Gospel story could scarcely be doubted in the light of subsequent historical social developments-a point which some critics have often overlooked. Social movements do not originate without social leaders, and great historical movements which have profoundly affected civilization require personalities which bring to a focus, as it were, certain social tendencies, thus giving a new impetus and direction to social development.

The principles of psychology also aid in giving certainty to the essential truthfulness and historicity of the figure of Jesus. This has impressed practically all students who have brought an open mind to the question. If such sociological, psychological, and anthropological

'For example, see Schweitzer's review of the work of the German theologians from Reimarus to Wrede in his The Quest of the Historical Jesus. The results, as Schweitzer himself acknowledges, are mainly negative.

'Such credibility would surely never have been questioned had not the teaching of Jesus been involved in partisan disputation. 
principles be rejected, we are left without any positive science of human history and plunged into the absurdities of absolute historical skepticism. ${ }^{1}$

We may, therefore, accept the essential truth, even upon a purely scientific basis, of the account of Jesus' teachings and life contained in the Gospels. Reasonable faith built upon these scientific principles will, of course, go much further and say that the burden of proof obviously rests upon those who would reject the account of Jesus' teachings and life contained in the Gospels.

What, then, did Jesus say concerning himself? What were the claims which he himself made upon his followers? That they were no inconsiderable claims the Gospel record, as well as the history of the Christian church, bears witness. Jesus was conscious in the highest degree of his world mission. He believed himself sent by God, not only to redeem his people, but all the nations of the earth. He proclaimed himself the Messiah foretold by the Prophets, ${ }^{2}$ sent to redecm Israel and establish God's kingdom upon earth. He spoke of himself, however, not so much as representing his own people as mankind in general, namely as "the Son of Man"; ${ }^{3}$ only

${ }^{1}$ The extreme to which such skepticism may go is also seen in the case of Buddha, whose historic existence has been doubted by one school of writers. Compare Glover, The Jesus of History, pp. 5-9.

${ }^{2}$ Some careful New Testament scholars think that Jesus never proclaimed himself as the Messiah. Sec Case, The Millennial Hope, p. $114 \mathrm{f}$.

'This term has caused endless controversy among the critics. See articles in Encyclopedia Biblica (Vol. IV) and in Hastings Diction ary of the Bible. While the term in Jewish apocalyptic writings was used as one of the titles of the Messiah, it is improbable that Jesus used it in this sense. As Bishop Westcott said: "It is inconceivable that the Lord should have adopted a title which was popularly held to be synonymous with that of the Messiah while he carefully avoided the title of Messiah itsclf." In other words, it is improbable that Jesus used the term generally in the apoealyptic sense, but rather in the simpler sense the term had in the Aramaic which Jesus spoke, 
twice in the records of his ministry do we find him speaking of himself as representing God, namely as "the Son of God." Nevertheless, he does not hesitate to say, on several occasions, many things which indicate clearly his sense of his mission as a redeemer of mankind. "I am the way, the truth, and the life," he says. Again, "No man cometh to the Father except through me." 1

Now, we cannot possibly dismiss these bold claims which Jesus made for himself even though they are similar to the claims which have been made by the founders of other religions. The question still remains, was Jesus a religious fanatic? Was he insane, or was he profoundly sane? It may be pointed out, in the first place, that all of the greatest leaders of mankind, not only in religion, but in art, in science, and in statecraft have usually been highly conscious of what they have accomplished and of their gifts. The so-called extravagant claims of Jesus could be paralleled many times, for example, by the great claims put forth by men of science for their discoveries. It is no more to be wondered at that Tesus was highly conscious of the supreme worth of his discoveries in the moral and religious realm than that a Kepler or a Galileo was conscious of the worth of their discoveries. "Again, all of the great active leaders of man-

namely, "the man," or "the representative of man." See especially article by Professor Schmidt above referred to in the Encyclopedia Biblica.

${ }^{1}$ These strongest statements attributed to Jesus are from the fourth Gospel, which is generally recognized by scholars in all branches of the church to be of uncertain authorship. They are, however, in line with some other sayings of Jesus, and in substantial harmony with the spirit of the first three Gospels. That the ideas which they express were a part of the early Christian tradition seems, therefore, probable. They are purposely cited here as examples of the extreme Christian tradition. Even so, if taken in a practical rather than in a theological sense, they are not irrational, but accord with Christian experience.

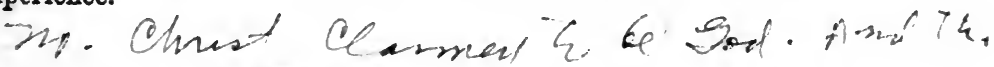

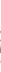




\section{THE RECONSTRUCTION OF RELIGION}

kind have been more or less conscious of the convergence of social and historical forces in their own personality and in their life work. It is not surprising, then, that Jesus showed this consciousness to the highest degree. He lived at a period when the contending forces of the social and religious life of the Jews, and, for that matter, of the Greco-Roman world, were coming to a head. His soul rose superior to the petty, reactionary, particularistic tendencies of his time in religion and ethics, and he felt himself commissioned to realize the nobler dreams and aspirations of his people, especially, those of the later prophets. His was the pure and sensitive soul in which the noblest traditions of Jewish religion and ethics became intensified and still further idealized. Passing through his transcendent personality the best in Jewish traditions underwent a new synthesis, creating a new religious and ethical attitude, fitted, as we have already said, to mediate the transition from the standards of barbarism to those of higher civilization. [Thus, Jesus became the spiritual leader and savior of mankind, the initiator of a new age which would in time establish the reign of God among men even as it was already established in the rest of the universe.

Taking into account Jesus' position in time and his work, his consciousness of his mission and of the truth of his teachings, his claims for himself were not extravagant. $^{2}$ Indeed, no one who accepts his leadership and his

'Says Professor Simkhovitch: "There is no question in my mind that Christ's deep conviction that his is the Way and the Truth was based on knowledge, intellectual knowledge, scientific knowledge, if you please. Before he felt that he was the Redeemer, he knew himself to be the great Discoverer. . . . To me, personally, it seems childish not to see in Christ's teachings an overwhelming intellectual systern. The towering parts that are its components are parts of the same system, not independent units. The truth of the insight, the cohesion of the system were self-evident to Christ; so much so that he knew 
teachings can do anything but acknowledge that in a profound sense he is the way, the truth, and the life, and that no man can come to the Father except through his spirit, through belief in him and the acceptance of his leadership and so of his saviorship. Jesus' life and teaching was characterized, then, by the highest sanity, not by the sanity of a low prudence or of a false humility, but by the sanity of an exalted mood, such as has characterized all of the greater leaders of mankind. Positive Christianity will recognize fully these facts, and in accepting the leadership of Jesus will take him at his own valuation. It will recognize that in these statements and claims of Jesus there is the best evidence of his fitness for spiritual leadership.

For men must have leaders in order to accomplish anything great in any line; and this is particularly true of the social world, of ethical and religious matters where great vision and deep enthusiasm are needed to lead effectively. No human cause can be successful until it crystallizes, so to speak, about one or more personalities. Not until the cause, the movement is embodied in one or more masterful personalities who lead the mass is there any chance of the success of the cause. This is as true of bad causes as it is of good ones. Men are not sufficiently motivated by abstract ideas; it is rather loyalty to a concrete personality, or rather to a series of such personalities, which sways them. It is thus that men are saved;

that they had an absolute quality; that is, coming from God." Toward the Understanding of Jesus, pp. 57 and 71. Perhaps no scientific student of society has treated Jesus's consciousness of his mission with such lucidity and penetration as Professor Simkhovitch. The book from which we have just quoted has rightly been said to give "a more realistic grasp of the entire situation and a more intimate understanding of the aims and methods of Jesus than a century of minute literary criticism of New Testament documents has been able to discover." 
and it is in this sense that the rational Christian finds in Jesus his personal savior.

The experience of Christians through the centuries, and even of many outside of the church, testifies to the essential truth of the claims which Jesus himself put forth. In his life and teachings men have found not simply their best comprehension of the divine and of personal redemption from low and mean social tendencies, but an unfailing source of aspiration and enthusiasm for a better social order. "Each new crusade in the long strife for human betterment," Professor Fitch truly says, "looks in sublime confidence to him as its forerunner and defense." None can deny accordingly that Jesus as an ideal figure has, as a matter of fact, established his leadership of all who look for a human society based upon love. ${ }^{1}$ There is no hope of the realization of a social life dominated by love without Jesus, for there is no one to whom the world would turn for such a vision if his leadership were denied. ${ }^{2}$ And in making himself the moral and social leader of mankind he has surely become the redeemer and savior of his fellowmen.] These facts must be acknowledged by all who would pass judgment upon the claims of Jesus;

${ }^{1}$ It is, of course, true that the central figure of the Christian movement is not the historical Jesus alone, but a growing symbol, to which are attached, as they develop, our highest spiritual aspirations. The same thing is true of any other great historical leader, as, e.g., Lineoln. To this extent, but to this only, can we agree with those who would minimize the importance of the historieal Jesus. We may perhaps nearly agree with Schweitzer, despite his eschatological views, when he says (op. cit. p. 401): "Not the historical Jesus, but the spirit which goes forth from Him" is the thing of supreme importance in religion.

${ }^{2}$ Surely not Buddha and Buddhism, for Buddhism is essentially a scheme of individual salvation and presents no ideal society as its goal Self-mastery, not service, is its ideal-individual salvation, and not a redeemed world. Whatever its merits on the individual side, its inculcation of passivity, quietism and asceticism throw it out of harmony, not only with modern civilization, but also with social needs and hence with social science. See p. 68 . 
and they are the chief scientific ground for recognizing the validity of his claim to be in a spiritual sense the savior of mankind. And until mankind recognizes the validity of this claim and acknowledges him as savior and leader, it will remain barbarous and lost in sin. ${ }^{1}$

Positive Christianity, accordingly, instead of groping in the dark to find some great, simple soul who will lead the world out of its present chaos, will point to Jesus without any spirit of religious mysticism as the ample and sufficient leader of mankind. It awaits and expects no other leader. It knows that the knowledge as well as the heart of mankind will testify to the adequacy of his leadership in ethical and religious matters. It knows that a benighted and barbarous world has yet to accept his social saviorship. It knows that a world fully awake to true social and religious values will say, as a modern rationalist outside of the church has said: "Jesus Christ, come back! The tones of your voice have not yet died away. In spite of false creeds and wizard priests, through craft and rant, the heart of our age still turns to you. Touch the sorcery of our time and wake us from the vile enchantment of fear and foolish hate. Come! Deliver us from the doom of dead things. Bring life from the grave where faith lies bound. Jesus

1 Even a hostile, though fair, critic of Christianity (Sellars: The Next Step in Religion, p. 96) is compelled to acknowledge: "In the figure of Jesus, ethical and aesthetic idealization guided by religious emotion has created a personality of a peculiarly appealing type, well fitted to remain as an ideal to foster and strengthen the noblest tendencies." Compare also the appreciative statement of Rabbi H. G. Enelow, which may be taken as typical of the liberal Jewish attitude: "Among the great and the good that the human race has produced, none has even approached Jesus in universality of appeal and sway. . . He has become the most fascinating igure in history." (A Jewish Vievo of Jesus, p. 181.) 
Christ, come back! Bring dreams and let dreams come true! Bring love that knits all hearts into one."

And yet, positive Christianity will emphasize, not so much an emotional attachment to Jesus' person, important as that may be, as a rational understanding and acceptance of Jesus' teachings. Of emotional Christianity the world has had enough and has proved its utter inadequacy, except when it is accompanied by a thorough comprehension and radical acceptance of the teachings of Christianity's leader. It is probably safe to say that not one out of four of those whom the church has persuaded emotionally to accept Jesus as their savior can give any rational account of Jesus' teachings. ${ }^{1}$ This, of course, has been one of the main reasons for the failure of Christianity to become socially effective. A thorough understanding of the practical social meaning of the teachings of the Master will not detract from the reverence and love of his person, and it will add greatly to the effectiveness of Christian ideals in practical life.

These statements bring us, naturally, to a consideration of the importance for positive Christianity of the study of the Bible and, especially, of Jesus' teachings. No one would expect to complete an education along artistic lines, or to become an artist, without the study of the work of great masters. No one would expect to become a worth while scientific worker or thinker in any line without study of the great scientific masterpieces in that line. So, it is idle to think that any one can become moral and re-

${ }^{1}$ It is, of course, the spirit of Jesus' teachings, rather than the letter which Christians need to understand. Says Professor Coe (A Social Theory of Religious Education, p. 315): "The most daring and most unflinching social teaching will never cease to look back to Jesus. But if it sees Jesus, it will look with him to the future. It will breathe his spirit, but it will not stop with his words." See also Chapter XI of this book. 
ligious in a rational way without the study of the great masterpieces in ethics and religion. Now, by the common consent of all the great religious thinkers of our civilization the supreme religious masterpieces of our cultural tradition are embodied in that unique collection of literature which we term the Bible. The ethical and religious value of the Bible, especially of the Gospels, for the establishment of Christian civilization cannot be doubted. Fother things being equal, a people will be Christian directly in proportion to the attention which they pay to the teachings of Jesus as found in the Bible.) One of the best evidences of the decay of the hold of Christian ideals upon our civilization is the small attention given to the Bible at the present time. It is idle to suppose that these ideals can become socially prevalent mental patterns without continued attention and study, especially on the part of the young. [However much our religious life must be based upon the actual facts of experience, it still remains true that/Christian principles and ideals can best be understood by studying them in the original sources.) While these sources should not be regarded with superstition, but should be subject to the same standards of criticism which we would apply to any other original sources, yet it must be recognized that we find in the Bible the original "source material" for the rise, development, and meaning of the Christian movement. It is not an accident, therefore, that Christians have discovered in this great collection of literature the chief inspiration for their own ideals and practical living. Positive Christianity, freeing the Bible from superstition and misunderstanding, will give it its proper place in the religious life as the great sourcebook of religious idealism. The uncritical use of the Bible like the uncritical use of any other classic, however, 


\section{THE RECONSTRUCTION OF RELIGION}

will be condemned as not in accord with the scientific spirit. ${ }^{2}$ Its use will be to reveal the origin, development, and nature of the Christian ideal.

The attitude of positive Christianity toward prayer will also be unequivocal. All religions, except the very lowest, are characterized by the use of prayer, or by what amounts to the same thing, introspective meditation. It is indeed in this way that the religious attitude of mind functions as a sort of moral equilibrator. Without it the full energies of the moral and religious life are scarcely

1 Some statement of the attitude of the author toward the Biblical criticism of the nineteenth century may be helpful in order to avoid misunderstanding. In general, critical scholarship is to be welcomed along every line of human interest for reasons which were briefly noted at the very beginning of this book. But there are many reasons why the critical movement in religion and theology of the nineteenth century, especially as developed in Germany, cannot be considered tho acme of scholarship. In the first place, criticism to be truly productive must be constructive. It should not be mere destructive skepticism. Institutions as well as individuals have a right to demand that criticism be constructive. In the second place, the importance of documentary criticism may be easily exaggerated, and such criticism itself become a sort of scholasticism. While the Bible is infinitely precious for the Christian movement, yet the Christian movement exists independent of the Bible and would probably continue to exist were there no Bible. This is not always appreciated by some schools of eritics and hence they have had often an exaggerated idea of the importance of their work. It is not too much to say that a great deal of it has been irrelevant to the great issues of religion. The entire documents of Christianity, Mohammedanism, and Buddhism might conceivably be lost; yet the problem of the Christian movement, the Moliammedan movement, the Buddhist movement, would remain essentially the same for the world. Growing out of the scholasticism of the crities there has been, in the third place, often a failure among them to appreciate the bearing of nearly related sciences upon their work. They have failed, in other words, in synthetic scholarship in many cases. The astounding archrological, anthropological, sociological, and psychological errors of some of them must of course be attributed in part to the time in which they wrote, but also in part to lack of synthetic scholarship. All of which shows that the ideas of the crities must not be taken for scientific truth, and that much of their work needs to be done over in a different spirit, more constructive, more synthetic, more scientitic. British and American scholars are now doing this. 
capable of control and direction. ${ }^{1}$ It is through prayer in every religion that the worshipper and the deity come into communion. It establishes a social and personal relationship between them, and the social efficacy of religion is secured through this mental comradeship of the human and the divine. God becomes the Great Companion only to the extent that conversation with him is maintained. Inasmuch as prayer means the social energizing of the personality through a sense of communion with the divine, it is something which increases with the higher evolution of religion rather than decreases. ${ }^{2}$ In Christianity the ideal is that the whole life shall become a prayer, in the sense that the inner personal life shall ever be kept in constant communion with the divine. At the same time it is evident that when prayer becomes thus an attitude pervading all practical living on a high religious plane, it must lose the magical character which it once had, not only in the religions antecedent to Christianity, but also often in theological Christianity itself. It must become a rational religious practice.

- What then must be the conception of prayer in rational religion? Surely not that the order of the universe is changed by it. This violates the fundamental principle which we laid down in the beginning, that religion and religious practices are for the sake of adaptation. Prayer is simply one method by which the religious attitude secures the adaptation of the individual to life and its environing forces. It secures this adaptation not through changing the order of the universe, but through changing

${ }^{2}$ For a brief psychological statement of the effect of prayer, see Hall : Mrorale, p. 350; for a fuller psychological discussion, sce James: Varieties of Religious Experience, pp. 463, 477 and 528. James calls prayer "the very soul and essence of religion." See also Coe: The Psychology of Religion, Chapter XVII.

2 Prayer in the strict sense is relatively rare in the lower religions. 


\section{6

the attitudes of men to their ideals, to one another, and to the great forces of life and the universe. But this change in the human attitude is the thing that is supremely necessary to bring about the benefits which religion seeks. There is, therefore, no necessary element of self-delusion in prayer. On the contrary, if the assumption of sane religion must be what we have said, that "only man is vile," then only man needs to be changed, not God or the order of the universe. ${ }^{1}$ [ Salvation, both personal and social, can come to man only through the change in his inner life; and it is prayer which is the effective agency of bringing about these changes and in controlling them so that ideals shall be realized. The experience of religious persons testifies universally to the efficacy of prayer and no positive religion based upon the facts of life will deny this. On the contrary, it will give not only a more rational place to prayer in the religious life, but a larger one than mere superstition can possibly do.

We must always remember that motivation, energizing of the will, is in one sense the supreme function of religion, and that the practice of prayer, like the beliefs in God, immortality, and salvation, plays here a great part. The problem is how to make all these work in the right direction. It must be admitted that many of the prayers of religious people are neither rational nor ethical, and this a positive social Christianity must correct. In part, no doubt, prayer is often instinctive, a mere cry for help to the superhuman forces of the universe. Even when it has become partly rational it still frequently remains grossly unethical, as in the prayers not only of children

1 The moral order being necessarily coïperative, it is, of course, as right to conceive that God needs man's help as that man needs God's help. Man and God are co-partners in a common task. But the imperfections in this coöperation are on man's side, not on God's. 
and criminals, but also sometimes of respectable church members. There is too much prayer which is pagan and selfish. Obviously prayer can be tolerated in a social religion only as it is directed toward spiritual ends and accords with the higher social values.

This does not mean, however, that there should be any sort of social censorship upon prayer or the forms of worship. The right of the individual to worship as seems best to him and to appeal to God over the decisions of the mass of his fellowmen is salutary. This freedom, which the individual may claim, of direct communion with, and appeal to, the deity is one of the most precious achievements of the higher ethical religions. But in reality the recognition of this right of free access of every individual to God and of freedom of worship is in accord with the highest social values; for it makes the individual religious attitude directly creative, not only of personal character, but also of social order. It is therefore really in accord with the general principle which we have laid down, that rational religion must demand that prayer and religious practices in general be directed to spiritual and social ends; for freedom in these matters, experience has shown, best conduces to higher spiritual and social development.

Positive Christianity will be tolerant, not only in these matters, but in all matters of religious belief and practice; for with science it will share the supreme faith that all that truth needs to establish itself is a fair field and no favors. The world understands the absurdity of trying to establish scientific truth by any degree of coercion. It should see the equal absurdity of trying to secure the acceptance of religious and moral truth by any coercion. The appeal of a positive religion, like that of science, will be to the facts of life and to intelligence. Hence a posi- 


\section{THE RECONSTRUCTION OF RELIGION}

tive Christianity will be tolerant even of non-Christian religions. It will welcome whatever they have to give which is of value. It will be willing to judge them by their fruits, and especially by their effects upon social life and human culture.

But the toleration of positive Christianity ean, no more than that of science, be a toleration of error. It asks that all religious sects submit their beliefs to the tests of experience and reason. No doubt a large liberty will always be tolerated in transcendental beliefs, but when such beliefs vitally affect human relations their truth or falsity must be judged by their fruits. To be tolerated in a rational and social world they must be such as to serve mankind. In the long run, at the least, they must show that they will result in a better human world-in increasing rather than diminishing human fellowship. For religion exists for man, not man for religion. To this extent positive Christianity will agree with Comte that in its values and judgments religion must be anthropocentric; that is to say, it must be developed in harmony with social science. This is only reiterating, however, our fundamental principles that religion is an adaptive process, that it should be redemptive, and that humanity is the ultimate subject of its redemption.

Many proposals are being put forth for the creation and establishment of a new religion, since Christianity, it is asserted, is hopelessly discredited. But the religion of Jesus has not been discredited; it is only the practices of so-called Christians and Christian churches. Apart from the difficulties of such an enterprise under the complex conditions of modern life, a new religion would surely defeat its very purpose. For what our world needs most at the present time is to acknowledge the social and moral 
leadership of Jesus. The most idealistic religious movement that neglected this element of personal leadership would defeat itself. If there be those to whom the word "Christian" is an offense on account of misrepresentations of the Christian spirit and life, yet who sincerely desire a Christian world, one dominated by active good will, then the rational thing for all who call themselves Christians is to demonstrate what the true Christian spirit is. When this is done, and when moreover people understand that scientifically the work of Jesus in religion and ethics is comparable to the work of the great founders of modern sciences, then there will be no more objection to Christian religion than to Copernican astronomy. Intellectually one will be as readily accepted as the other.

The solution which positive Christianity proposes of the religious problem of our time, then, is simple. Let the religious leaders of our day grasp the full social significance of religion, drop their theological disputations, give religion the positive, humanitarian trend which civilization demands, recognize that their essential work is the maintenance and propagation of rational social values, and teach clearly, as Jesus did, that the only possible service of God must consist in the service of men regardless of their race, class, or condition. Let also the recognized basis of religious fellowship become full consecration to the service of mankind. If this were done, not only would the churches forget their traditional differences, but they would rally to their support all good men everywhere and eventually overcome all their active opponents. ${ }^{1}$ This is not advocating something novel. 'Al-

${ }^{1}$ Again we may quote Conklin (op. cit. p. 244): "The time may come sooner than some of us expect when in all things except spirit and purpose, religion may once more be a personal matter; when churches will welcome all men of good will; when love of God and love of fellow men will be the one requirement for mutual fellowship 


\section{THE RECONSTRUCTION OF RELIGION}

ready this movement is well under way in the more advanced Christian churches. But the time has come to take seriously in hand the reconstruction of our religious life along humanitarian lines. For it is only an actually realized humanitarian religion, sanctioning and enforcing a humanitarian ethics and working in harmony with modern social science which can guarantee peace and good will among classes, nations, and races, and prevent the collapse of our civilization. On the other hand if such a religion of human service becomes generally accepted all of the irrational, unsocial, and unprogressive elements in our religious life would disappear, and actual Christianity would become "the religion of humanity."

and service. When that time comes, religion and science will be at one." For a simple outline of such a Christianity in harmony with modern science, see Ames, The New Orthodoxy. 


\section{CHAPTER VI}

\section{THE ESSENTIALS OF A SOCIAL RELIGION}

We have outlined the great general principles which we must follow if we are to reconstruct religion so as to meet the requirements of modern life. Now we must try to see the social implications of all this, both in general and in particular. What social principles, in other words, does social science ${ }^{1}$ indicate as essential for a positive social religion? If institutions are to be saved as well as individuals, what is the doctrine of social salvation? How shall we build our social world? If we build it in accordance with modern social science, will it turn out to be the world of Jesus' vision, a "kingdom of God?" 2 These questions we shall try to answer in the succeeding chapters of this book.

In part we have already indicated the answers. We have seen, for example, that social science demands a religion which will release the creative energies of man; which will not only inspire faith and hope in individual life, but enthuse communities for progress; which will not

1 The term "social science," it should be remembered, is used in this book to include not only the "pure" social sciences, but also social ethics and the applied social sciences. See foot-note in Preface, p. $x$.

${ }^{2}$ A number of writers following Coe (see his Social Theory of Religious Education) prefer such a term as "the democracy of God," or "the commonwealth of God," as the New Testament "kingdom of God" is thought no longer properly to convey the meaning intended. The exact term employed is, of course, immaterial, provided the proper social content is given to it, corresponding to the content given to the New Testament term by Jesus. 


\section{THE RECONSTRUCTION OF RELIGION}

only strengthen and uplift individuals, but send them forth to build a new and better social world. We have seen that such a religion must depend practically upon knowledge of all the forces which make or mar human life, whether in its individual or in its collective aspects; that is, it must ally itself with science. A positive social religion and social science will be accordingly in practice inseparable. We have seen finally that such a religion will blend religion and ethics by giving a social direction to religious practices, recognizing that the only possible service of God must consist in the service of men-the fundamental principle, as we have so often reiterated, of the religion of Jesus.

The postulate of such a religion of human service must, of course, be the supreme worth of men, no matter what their race, class, or condition may be, so that even the humblest service done for men takes on a new dignity, because it is a service rendered to God. This is the central teaching of all social religion, and of the religion of Jesus in particular. Is it the teaching of social science?

Modern social science shows beyond question that all the wealth of the world really resides in men; that there are no values of any sort apart from men; and that all the values which we know are their creation. Human beings, in other words, are not only the sole sources of value, but they are the supreme values. The development of the resources which are in men, therefore, is the only way in which the world can be permanently enriched along any line. ${ }^{1}$ Hence the greatest concern of human society must be the production of men who can take their

1 This truth, now accepted by all economists, received early and vigorous championship by such economic writers as Richard T. Ely in America and J. A. Hobson in England. Compare Carver, Principles of Political Economy, Chapter VI. 
place in our human world and help to carry on its life in the best ways possible.

But it is not men in isolation that social science discovers to be valuable. Men create values only by coming into relationships with other men, and they create them directly in proportion as they work together successfully at the tasks of life. The collective life of men which we call society, in other words, is carried on by the continual exchange of services between men. It is by mutual service that men live. It is this reciprocity of service which is the basis of all human institutions and all civilization. The more intense this exchange of services is, the more social values are produced and the more social life is built up; and the more equal the exchange is, the more satisfying and harmonious is the social life. ${ }^{1}$ In other words, social science finds co-operation to be the inner, constructive principle of group life; and the wider and the more harmonious this co-operation is, the richer and the more perfect is the social life of mankind as a whole. ${ }^{2}$ Civilization and all its values, then, depend upon the continuance and development of co-operation among men. Obviously a social religion must aim to maximize co-operation, and it will be successful in doing this only as it teaches the value of mutual service. The inculcation in the in-

${ }^{1}$ See Novicow, "Mechanism and Limits of Human Association" (in American Journal of Sociology, November, 1917), especially Chapters II and III.

2 Practically all modern sociology of scientific standing has united to demonstrate this truth. See, e. g., Small, General Sociology, p. 710; Ross, Principles of Sociology, Chapter XXI; Todd, Theories of Social Progress, p. 41. On the biological side evidence will be found in such writers, among many others, as J. Arthur Thomson, David Starr Jordan, Vernon Kellogg, and William Patten. Professor Patten's recent work, The Grand Strategy of Evolution: The Social Philosophy of a Biologist, is especially interesting as showing that the conflict philosophy of society is without adequate biological foundation. See especially Chapter I. 
dividual of the attitude of service toward his fellows must, then, be the primary aim of a social religion.

If a social religion must first of all teach social service the question still remains what sort of service shall it be. Assuming always that the service is intelligent, is it to be rendered chiefly in a material or in a spiritual way? Is the most social religion the one which will maximize economic co-operation and economic production? Or will it pay even more attention to the production of non-economic values? Moreover, is service to be rendered indifferently to the strong and to the weak, or will social religion emphasize especially service to those in need of help?

There can be no doubt that social religion as well as social science must teach the fundamental importance of producing material goods and of satisfying the economic wants of men. Feeding the hungry and clothing the naked are obviously the primary services needed by human beings. Services rendered to meet the material needs of men, especially when these needs are great, are of the highest social, and so, ethical and religious, value; for until these needs are satisfied there can be no development of the higher, spiritual life of men. We must all agree that in this sense "the greatest service of all is the service of food." 1

But material goods, as Aristotle long ago remarked, though living in a pagan world, have a limit to their social utility; and that limit is their power to promote the development of the higher, spiritual life of men. Too great an abundance of material goods, so far from aiding higher social and moral development, becomes an impediment to it. This is true, so far as we know, even if material

1 For further discussion of the relations of religion and material needs, see Chapter VIII. 
goods are evenly distributed in society. No matter how evenly distributed, too great an abundance of material goods would be sure to undermine the higher spiritual life of men and lead to besotted materialism, in the moral sense of the term. It is true, of course, that the danger of too great a general abundance of material goods is relatively remote in our civilization, and that which appears to be such a danger is really due to the concentration of wealth in the hands of a few. But this fact cannot obscure the truth of the general principle that the social utility of material goods is limited, not only for any one social class, but for all social classes.

It is not an accident, then, that the higher religions quite generally condemn too great accumulation of such goods, and invariably counsel contentedness with small means. This is not merely to secure the distribution of such goods to the unfortunate, nor is it usually for the sake of mere asceticism, as is so often alleged. The reason is more simple; for as social science shows, the energy of society at a given time being a fixed quantity, energy devoted to the production of material goods after necessities are met cannot be devoted to building up family life, government, religion, art, science, and education. If we want the higher life of society in art, science, education, religion, government, and the family to develop, then, the energy devoted to the production of material goods must be limited.

To be sure, what are material necessities and what is jover-abundance of material goods, social science would isay, are relative matters, dependent upon the stage of social culture. But this does not detract from the force of the conclusion just stated, and it is evident therefore that it is not sufficient for social religion merely to teach 


\section{THE RECONSTRUCTION OF RELIGION}

that men render service when they work in the economic sense and are good producers. Society needs services beyond these economic services. The services rendered by individuals as fathers and mothers, as brothers and sisters, as friends and neighbors, as members of communities, through the family, government, art, religion, science, and education, in the production of healthy, happy, intelligent, unselfish men and women, may be dominantly noneconomic; but they are the services which count most in the building of civilization; and in proportion as men put energy into these services, after material necessities are provided, in that proportion is the ideal of social life realized. The production of men, not commodities, must be the aim of sound social religion. The end of all social service should, therefore, be spiritual. It would, indeed, be quite unnecessary to say these things if the prevailing materialism of our time had not obscured these truths and even often denied them. ${ }^{1}$

When social religion demands the complete consecration of the individual to the service of his fellowmen, therefore, it is calling him to a spiritual service. It is not the service of making men happy and contented animals, but rather of developing them into truly human, intelligent, loyal members of an ideal society - a redeemed humanity. And in this, social religion is one with the religion of Jesus, which, while recognizing the fundamental character of the needs of men in a material way, looks to their salvation into a spiritual social order as the end.

Is the human service, which social religion enjoins, to be rendered indifferently to the strong and the weak, or will it emphasize the scrvice of those who are in need of help? Modern social science diseovers that human com-

${ }^{2}$ See again Chapter VIII. 
munities progress very largely in proportion as they raise the general level or average of their total life; and this level is raised not by producing a few superior individuals, but by raising the weak, developing the undeveloped, and fitting as many as possible for the best possible life. Human societies, in other words, progress not through producing supermen, but through the diffusion of welfare and intelligence among the masses of mankind. It is in the undeveloped personalities and characters of men that society has its chief potential resources. Whenever the ignorant can be made intelligent, the vicious good, the physically weak the physically strong, society has added to the strength of all; for the strength of human groups consists in extending and intensifying their power to co-operate. All civilized human groups, therefore, strive to fit not only as many as possible of their members to survive, but for the best possible living. A sound social religion will, therefore, emphasize service to the needy and the weak. ${ }^{2}$ Its emphasis will not be so much upon the fraternity of the strong as upon showing fraternity toward those who need help.

This we have seen is a distinctive mark of Christianity. As a social religion its peculiar note has been the redemption of the vicious, the helping of the needy, and the strengthening of the weak. In our world, so far as we can see, for a long time to come, social religion will have to emphasize this redemptive work. Its main practical preoccupation will have to be bringing knowledge to the ignorant, virtue to the vicious, health to the sick, wealth

1 A further sociological reason for this is the impossibility under modern conditions of maintaining in the same community two different levels of civilization without gravitation toward the lower level. No community, in other words, can rise far above its worst socially tolerated conditions. Vice or typhoid, e. g., in one section of the community endangers all the rest. This is a familiar sociological principle. 
to the poverty stricken, and strength to the weak of every sort. It will seek to do this, to be sure, by prevention, wherever possible, rather than by cure; but the chasms which exist in modern society must be bridged, and they cannot be bridged by levelling men down, but only by helping them up to higher levels whenever and wherever that is possible. A religion which is adapted to the requirements of our present world must very evidently be a socially redemptive religion.

But service which is rendered under compulsion, even though it be only the compulsion of religious and moral precepts, soon becomes slavery. Only a service which is spontaneous, which springs from inner motives, can continue to be rendered gladly. A social religion that merely teaches service as an outward form is not enough. Social religion must above all, therefore, cultivate the inner attitudes and motives which issue in service. A genuinely social religion must teach emotional attitudes which naturally, spontaneously, issue in social service. It must, as we say, touch the heart of man. In other words, a social religion must kindle the sympathetic emotions. Service must be motivated by love to have the highest social value. Religion must become a great device to accumulate, diffuse, and transmit altruism in society. It must inculcate the love of man as man. It must develop a sense of human brotherhood throughout humanity. It must cultivate love, not simply towards a few men, towards one's own social set, or nation, or race, but towards all men. ${ }^{1}$

This is not "oriental mysticism," as it is so often said

' Compare the argument in Hobhouse, The Rational Good, especially Chapter VI. The word "love" is used in this chapter and throughout the book, of course, in the ethical sense, meaning active good wiv or devotion to the welfare of others. 
to be by the "hard" school of social thinkers; nor is it impracticable. On the contrary, social experience shows that the only secure foundation of co-operation in human groups is active good will based upon the sympathy and understanding of all their members, and that human cooperation has widened in proportion as sympathy and the consciousness of kind have widened. ${ }^{1}$ Wherever the attempt has been made to base co-operation upon mere self-interest, there an unstable social situation has resulted, which sooner or later has issued in open conflict. Only good will based upon active sympathy has proved equal to producing lasting social solidarity.

This is natural, some may say, in small human groups such as the family, the local community, the ancient citystate, and even in modern social classes; but it is impossible where there are wide differences among men, and especially differences in material interests; there it becomes "mysticism." But social investigation shows that there has been a constant expansion of sympathy and good will in human history to larger and larger groups, and that we cannot set limits to this expansion, which apparently depends entirely upon the education of individuals. ${ }^{2}$

${ }^{1}$ See the author's Introduction to Social Psychology, pp. 255-256. Compare also Professor Giddings's statement of the same conclusion in his Descriptive and Historical Sociology, pp. 298-300, 303-305, 352-355.

'Says Professor Cooley (Social Organization, p. 203) : "The mind, in its best moments, is naturally Christian; because when we are most fully alive to the life about us, the sympathetic becomes the rational; what is good for you is good for me because I share your life: and I need no urging to do by you as I would have you do by me. Justice and kindness are matters of course, and also humility, which comes from being aware of something superior to your ordinary self. To one in whom human nature is fully awake, 'love your enemies and do good to them that despitefully use you' is natural and easy, because despiteful people are seen to be in a state of unhappy aberration from the higher life of kindness, and there is an impulse to help them to get back." But all this depends, as Todd points out (Theories of Social Progress, Chapter V), upon the cultivation and development of a sympathetic or socially efficient imagination. 
It shows, moreover, that religion especially has proved able to break down the differences between men and unite the most diverse in bonds of sympathy and good will, or love. This, indeed, we have seen to be the essential social function on the feeling side of humanitarian religion. By universalizing sympathetic feeling, or love, it makes possible the widest possible mutual service and co-operation. Hence the first and great commandment of social religion must be universal love, or good will, extending even to enemies, and reconciling all men to one another. To become dynamic, to affect human motives, a social religion must promote human fellowship and so must teach men to cultivate sympathy, love.

We have said much about the need of intelligence in social relations and even of the need of the control of emotions by intelligence. But, even from the standpoint of social science, we must admit the equal need of good will to build an ideal society. In our present human world with its seemingly hopeless division into hostile groups of all sorts, we would seem to be more in need of good will, indeed, than of intelligence; for until good will has laid a basis for some approach there would seem to be little opportunity for intelligence to function. When one contemplates the strife and hate of our present world, one might be pardoned if he claimed that the world needs good will more than science or art, yes, even more than food and shelter. For knowledge can be secured and nature conquered by men co-operating in the work of life; but knowledge and material goods avail nothing if good will is lacking. Moreover, good will appears equally necessary with science for overcoming strife, crime, poverty, and ignorance. For man lives a collective life; he shares his fate with his fellow-men around him, and so 


\section{ESSENTIALS OF A SOCIAL RELIGION 171}

of necessity he lives in and through good will. No man lives to himself alone. We are all members one of another. If any, even the humblest, is made to suffer, every one of us, whether or not we recognize the fact, is thereby injured. These assertions are not mere sentiment; they are a part of the perceptions of sound social science. "The whole human problem," as Comte said, "consists in establishing unity, personal and social, by the constant subordination of selfishness to altruism."

It is here, of course, that science discovers the special need of social religion if ever co-operation is to take the place of the world-wide strife of the present; for only social religion can universalize love, or good will, in our world. Material interests and a thousand other things divide men. It is religion, as we have seen, which universalizes social values. Sane science recognizes that it alone cannot bridge the chasms which exist in our human world. Men's hearts must be touched. To bridge the chasms which now separate in so many cases classes, nations, and races a religion of universal love is alone adequate. This is true even oftentimes in small communities. Even in them our imperfectly developed civilization often premits chasms in their sympathies to grow up between men which make real unity impossible in social living, and which only a religion that cultivates social sympathy, or love, can effectively bridge.

But even more do we need a social or humanitarian religion in the relations of the greater groups of men, such as classes, nations, and races. Here the need of reconciliation is most apparent, for here strife is at its maximum. It is group egoism which particularly disturbs our world at present, and menaces its future even more. If the world wants peace, it must find a way of breaking down the barriers of misunderstanding and 
selfishness which now separate classes, nations, and races, and of realizing universal human fellowship. Science can aid here by showing the essential identity and universal interdependence of all men. But fellowship is realized not simply through understanding, but even more through sympathy and active good will. Manifestly, where there are so many possibilities of misunderstanding through differences of place, of interests, and of condition, there is especial need of a religion which shall cultivate universal sympathy and good will, or love, and shall intermediate between such great groups.

This is especially so in the case of nations and races, for here the traditional attitude has been not only one of egoism and isolation, but also one of fear, distrust, and hate. No mere peace treaties, or league of nations, or "balance of power" can under such circumstances successfully put an end to strife. Rather the whole spirit of nations must be changed. A basis for enduring reconciliation must be found. Group egoism as a policy and practice must be discredited; and in place of fear, distrust, and hate must come understanding, confidence, and good will. Now, as Gautama Buddha said long before Jesus, "Hatred does not cease by hatred, but by love." 1 It is love, in other words, which overcomes hate and reconciles men to one another. This is as true of groups of men as of individuals. Manifestly "the healing of the nations" requires a religion of humanity, which shall teach the love and service of all men. Only thus can the foundations of enduring peace be laid.

No scientific social thinker doubts that the cessation of strife and the coming of durable peace is the great im-

${ }^{1}$ Rhys-Davids, Buddhism, p. 128. The exact quotation is, "For never in this world does hatred cease by hatred; hatred ceases by love; this is always its nature." 
mediate need of our world; for peace is an indispensable condition for all the constructive work of civilization. ${ }^{1}$ It is not simply international peace, however, which is needed, but rather general social peace; for at bottom all war is but a symptom of an egoistic, predatory spirit in civilization in general. Now, a religion of the love and service of all men would lay a foundation for lasting social peace, because, first of all, it would repudiate force and selfishness as bases for human relations and with them the whole pagan philosophy that might is right or can make right, that human beings can profit by living at the expense of other human beings, that to dominate is the end of existence. It would place in the stead of these anti-social doctrines, patterns of good will, of mutual service, of solidarity, of sacrifice for the good of all, taken from the family life. Such patterns, accepted as the supreme social values, would shatter group egoism and open up the way for the establishment and maintenance of normal, helpful, co-operative relations in the great groups of men, because the conciliatory attitude would then be held in honor, as it is now in the normal family; and when a wrong has been done, it would point the way to the restoration of social unity. Groups would no longer seek to remedy injustice by returning wrong for wrong, evil for evil, but by finding means of mutual conciliation. Their whole spirit would be changed, because their standards of conduct would be different and their attention would be centered upon co-operation rather than upon conflict. This is the only pathway to permanent social peace among men.

But how far, it may be asked, is this principle of active

${ }^{2}$ For elaboration, see the author's discussion of "War and Social Evolution," Chapter III, in America and the New Era, edited by E. M. Friedman. 


\section{THE RECONSTRUCTION OF RELIGION}

good will, or love, to be carried? Is it practicable unless it is accepted as the guiding principle of conduct by all ? Is it not, in a world so largely ruled by egoism as ours, apt to be nothing more than a mere hypocritical, and even dangerous, sentiment? The reply is that social science has discovered no way in which the world can be transformed from a world of egoism and strife to one of fellowship except by the leadership, and if necessary the suffering, of those who have the vision of a better human world. Men are imitative creatures. They are prone to treat others as they are treated by others. But they are also intelligent creatures, and they usually select as patterns for imitation conduct which experience shows to work best with themselves and with others. Hence while strife breeds strife, and hate breeds hate, kindliness also breeds kindliness, and love, love; but the superior satisfactions in the latter case are evident even to the dullest mind. There can be no question that kindliness and love would soon win out if this were a fully intelligent world.

But strong, brutal passions persist, and traditions of selfishness and strife are hard to uproot. However, to wait till all accept the principle of love as the guide of their conduct would be to postpone indefinitely progress toward a world of universal good will. Rather it is evident that the world must be redeemed by growing love as well as by growing intelligence. "Hatred does not cease by hatred, but by love." A positive social religion must teach love or good will, therefore, as an absolute principle. Lore must be extended to all, even to the lowest and meanest of mankind. Otherwise it must fail as the principle of social redemption. Love breeds love, good will, and because it is socially right it overcomes hate, just as truth, because it is right, overcomes error. It harmonizes, 
because it adjusts individuals, so far as motives are concerned, to the requirements of social life.

It is particularly necessary that good will be maintained toward enemies; otherwise there will be no basis for reconciliation and the restoration of genuine social relations. Plainly the duty of forgiveness is a clear corollary to the doctrine of universal good will. But this does not mean that we are to condone wrong-doing and meanness. Nor does it mean that we are to offer no impediment to the wrong-doer in his wrong-doing. But it does mean that we are to distinguish between the wrong-doer and his evil deed. While society must combat wrong-doing, its duty is always to reclaim the wrong-doer, if that is possible. Whatever it does to the wrong-doer must be dictated by good will, and must be for his social redemption as well as for the benefit of all. If physical force is to be employed, its use must be controlled by good will. The pattern here, as everywhere in the social life, is the family. There we do not reprehend the use of physical force under certain circumstances, provided that its use is controlled by intelligence and love. Its use is indeed necessary at times in the case of abnormal and undeveloped individuals, and is in no way inconsistent with the principle of love. So in society at large the use of physical force to stop wrong-doing when necessary is in no way inconsistent with the principle of universal love, provided its use is controlled by intelligent good will. Such, for example, is, or should be, the use of its police powers by an enlightened government. Indeed, as we shall see, good will, in order to be socially effective, must always be organized both negatively, to repress evil, and positively, to promote the good.

Social science does not find, therefore, that there is any 
necessary sentimentality or moral flabbiness connected with the principle of universal love; nor does it find any such taint attached to the concept of redeeming love. Love as a social principle does not mean "coddling"; nor does readiness to forgive encourage evil, as is sometimes claimed. Rather it is the only method of reclaiming and restoring the socially erring. This world is filled not only with undeveloped individuals and peoples who need help, but also with individuals and groups who have erred and socially lost their way. Indeed, since sin is a social matter-the outcome of social as well as individual conditions - practically the whole world presents this condition at the present time. A religion which is going to be any good in such a world must stress a sacrificial, redeeming love toward all men as the supreme need-a love which will lead men to sacrifice themselves without stint or limit in order to serve mankind; to die, if necessary, in order that the world may be freed from sin and error. Sacrifice as an end in itself cannot be justified by either sound religion or sound science; but sacrifice as a means of human service is an altogether different matter. Social religion regards sacrifice when prompted by love and made for the sake of human service the supreme measure of the ethical and religious spirit; and social science sees in such enthusiasm of humanity the height of social passion and, when guided and controlled by adequate intelligence, the best promise of the world's ultimate redemption.

But the sacrificial love which social religion inculcates has a more common, everyday significance, science discovers, apart from great socially redemptive movements. For men live together, social science reveals, not merely by the exchange of services, but also by the exchange of sacrifices-that is, by rendering services to one another 
for which no like service is, or can be, rendered in return. The very conditions of human life necessitate this. Every generation of men, for example, must stand, so to speak, upon the shoulders of the preceding generations. Uncounted toil and suffering of hundreds of generations have made possible whatever we enjoy to-day; but we too must toil and suffer if the world to-morrow is to live a nobler life.

But our imperfect social development necessitates even more that we live by the exchange of sacrifices. The wealth of the world, for example, is very inadequate to meet even reasonable human needs, and if the economic income of even the richest nations were equally divided, it would still be inadequate to maintain a proper standard of living for each family. But it is socially unwise and impossible to divide a society's economic income equally. Hence many must sacrifice and suffer that the life of, the group may continue and social evolution go on. While we rightly strive to lessen this sacrifice, yet no one can escape the conclusion that human progress in the past has rested, and at present rests, largely upon vicarious suffering-suffering for the sake of producing a better human world. "If we succeed without suffering, it is because some one has suffered before us; if we suffer without success, it is because some one will succeed after us." Thus the active good will which a social religion must seek to develop in men is one which will ever be ready to sacrifice self for the sake of service; for we can have an ideal society only when every person volunteers to sacrifice himself for the good of the whole.

Says Professor Small: "When men fully understand the world, they will understand that Jesus was right about sacrifice. They will understand that sacrifice is loss only so long as it is exceptional and forced. When we face 
sacrifice loyally, when we join in a general economy of sacrifice, when we refuse knowingly to gain except by intending a gain for somebody else, the balance of the total transactions with sacrifice will have passed from the debit to the credit side of the world's account. This is a vicarious world but not as stupidly conceived by the mediaeval theologians who located the one vicarious act of importance in the death on the cross. Life is vicarious in that its processes begin and continue and end with exchanges of sacrifices, wherever there are moral beings."

Here becomes evident the inadequacy of the ideal of justice, as ordinarily conceived - that is, "fair dealing"as the basic principle of social life. To be sure, we are so far from having achieved justice that to many it seems an adequate social ideal. Nor is it to be criticized as inconsistent with the principle of love. On the contrary, justice could not long exist in human relations without good will, and active good will is the surest guarantee of justice among men. Justice as a social principle is to be criticized as inadequate only in the sense that it is socially insufficient in such a world as ours. Active good will must go further than mere justice in its work of saving men and redeeming the world. Men need mercy as well as justice. Deep compassion for men, intense social feeling, cannot be satisfied with the virtue of the market place, "fair dealing," but only with the unstinted service which we find in the family when the motive is love. And such service alone, as we have seen, is adequate to build a right social life. It is no mistake, therefore, when the New Testament has little to say about justice and much to say about love, for justice as a social principle is included in and subordinate to the principle of love. 
Even more does the inadequacy of self-interest as a social principle become evident. Upon this pagan principle, as we have seen, our forefathers sought to build their political and economic life; and as a result our political and economic structures are tumbling about us. The question is not one of the legitimacy of self-interest; the question is one of the adequacy of self-interest. No one would deny that self-interest is legitimate up to a certain point; but to allow self-interest to dominate means to weaken and negative the social spirit, social unity, social co-operation. If it be true that hitherto "the chief motive power in the development of civilization has been intelligent selfishness," then that is one reason why our civilization is giving us so much trouble. For self-interest as a dominant motive is bound to result in social failure. Even in the economic sphere it is bound ultimately to fail. When it dominates, the worker will cease to work, will "curtail production," as soon as his selfish interest is satisfied; the employer will "retire" when his "pile" is made, unless he has in the meantime acquired an overmastering greed. Our world cannot hope to go forward to a social life that is harmonious and worth while on such a basis.

It is noteworthy indeed that even in the barbarous business of war, while group selfishness is usually appealed to, the appeal is rarely to the self-interest of the individual soldier, but rather to the spirit of unselfish, patriotic service. Now, peace has tasks which require equal discipline and devotion to unselfish ends for their successful completion. It is idle to think that the victories of peace can be won without the domination of the spirit of service and self-sacrifice. This is the whole secret of "morale," whether for peace-time or for war- 
time. Social science finds self-interest totally inadequate as a social principle for the construction of a high and stable civilization. It agrees, then, with social religion in condemning self-interest as a dominant motive and assigns it only a subordinate position in a properly developed social life.

The unselfish service in the building of a better human world, which social religion would make the immediate end of endeavor for both individuals and groups, however, leaves plenty of room for all legitimate self-interest. No man can serve humanity unless he develops the best that is in himself. No man can give unless he has something to give. The highest possible self-development for the sake of service is plainly a corollary of the ideal of service. But it is self-development for the sake of service, and not self-development as an end in itself. Indeed, the latter ideal has no meaning, if we accept the truth taught by social science that men necessarily live a collective life and achieve lasting good only through the development of this collective life. Self-interest subordinated to community interest and ultimately to the interest of humanity, self-development for the sake of aiding the development of humanity, is the plain teaching of both social science and social religion.

Nor does social science find this ideal inculcated by social religion at all impracticable? Nature has furnished man with both egoistic and altruistic impulses. While the egoistic impulses of the "natural" man are no doubt the stronger, yet which impulses will predominate in the character of the mature adult is altogether a matter of education. It depends upon which are cultivated from childhood up. It depends, then, upon the "morale" of the group in which the individual grows to maturity. 
Hence, again, the need of a social religion which will teach individuals to cultivate a spirit of unselfish service -altruism rather than egoism. It must be mainly through an essentially religious attitude that any high social morale is attained. For reasons which we have already fully explained, social religion is the great aid to a high social morale. But when a high morale is attained, when the social spirit is fully dereloped, there is no limit to the unselfish service of individuals which a group may command. If humanitarian religion, then, is given proper recognition as a means of social control, there is no need of individual and group selfishness running riot in our human world.

In drawing this discussion of the essential principles of a completely social or humanitarian religion to a close, it is scarcely necessary to point out that the principles which we have found to be essential are those of the religion of Jesus. Service of all men, even of the least, in material needs as well as in spiritual, in little things as well as in great, springing from love, or a social, brotherly spirit, ${ }^{1}$ carried, if need be, to the point of complete selfsacrifice-such was plainly his teaching. ${ }^{2}$ Coupled with this teaching was a profound conviction of the alienation of men from God, of their sinfulness and need of social and spiritual redemption. It is no mystery, as we have pointed out, why Jesus so taught. The mystery, if any, is why the world has not accepted his teaching. For his

1 The Greek agape, usually translated in the New Testament by the word "love," meant ethical love, or love enjoined as a duty, or active good will. See Thayer's Greek-English Lexicon of the New Testament.

' Professor Harry F. Ward (The New Social Order, p. 334) summarizes the fundamental social principles of Christianity as three: "the value of personality, the necessity of brotherhood, the law of service." 
social principles are so plainly the only ones by which men can satisfactorily live together that they might just as well forget the law of gravitation as forget these principles. When one forgets the principles of gravitation, one must expect some hard bumps. So when our human world forgets these principles of right living together, it must expect some hard lessons-such as it has been receiving.

There is, however, of course this significant difference between the working of the principle of gravitation and these social principles - that the ignoring of the first principle entails immediate punishment experienced by the immediate individuals concerned, while the ignoring of the latter entails a more or less remote punishment which may be experienced by quite other individuals than those immediately concerned. This, in part, explains the psychological difficulties of men in learning and understanding social principles. But to the eye of science as well as to the eye of religion the remoteness of the results makes no difference. To both, the social world, like the physical world, is a realm of law. Men reap what they sow in a social way, though the men that reap may not be the same as those who sowed.

Nor did Jesus make the mistake of teaching his social principles as abstractions. If he had done so, we could understand more easily the slowness of men in learning them. For men apprehend more quickly the concrete and give their loyalty more readily to persons than to abstract principles. A social religion which awakens the enthusiasm of men must present a vision of an ideal society and center about loyalty to a personal leader. Jesus was careful to demand this personal loyalty from his followers and to present to them a concrete ideal, the Kingdom of 
God-a social order in which God's will should be donewhich was to be the first thing to be sought by his disciples and the chief object of their desire.

It has often been said that "personality" is the highest term of religion, and that Christianity is "a religion of personality." This is surely correct only in a limited sense. We find Jesus saying little concerning individual personality, but much concerning his ideal society. While he regarded each human soul as of infinite worth, yet it was of worth because it was part of an ideal society, a part of a spiritual kingdom, which was to come fully only when the world was redeemed and God's will was done upon the earth. An ideal human world was to him the goal of religion. ${ }^{1}$

It would be quite as correct, then, to say that the highest term of religion is "humanity," and that Christianity is "a religion of humanity." Only if such is the fact can Christianity be in accord with social science. For social science discovers that it is the Great Community of humanity to which men have to adjust themselves, and by which all their values must finally be tested. A social religion accordingly must make humanity its highest category on the human side and the supreme object of loyalty. And this is loyalty to no abstraction. It is loyalty to the living human world, as the object of redemption. It is loyalty to all in religion, science, art, industry, government, or education which works toward that redemption. It is loyalty to the best that men have realized or aspired to anywhere. It is loyalty to that ideal human world which is to be.

This is surely not far from the thought of Jesus. When he asks loyalty to himself and to God it is surely for the sake of the redemption of mankind. When he demands

${ }^{1}$ See Chapter III and the various references there cited, also the foot-note on the next page. 


\section{THE RECONSTRUCTION OF RELIGION}

that loving service be rendered to the least of men as unto God, it is surely for the sake of the redemption of all men. When he commands his followers to seek first the establishment of the Kingdom of God, this is clearly his thought. For this phrase, at one time perverted by theologians to a supermundane or even ecclesiastical meaning, has been shown by modern scholarship on the whole to have reference to a social order upon this earth ${ }^{1}$-an order, however, not of mere brotherhood-for brothers may be co-conspirators in crime-but one in which God is acknowledged as father and his will is realized through the loving obedience of men to all his laws, especially to the laws of mutual love, mutual service, and mutual selfsacrifice for the sake of human service. This is the

1 No social order that is merely external, of course, is meant, but one which is an expression of an inner life in harmony with God's will. A purely subjective individualistic interpretation of this phrase, however, is scarcely warranted by its historical setting (its background being the expected Messianic kingdom of Judaism). More difficult to deal with is the extreme apocalyptic interpretation of this phrase (by Schweitzer and others). Regarding this interpretation, Professor Fitch justly says (in Christian Century, March 17, 1921): "All these considerations regarding the way of the appearance and actual organization of the kingdom are relatively beside the point. Whatever may have been the historical truth or falsity of Jesus' notion of the nature, the time, the method of the coming of the kingdom, the deeper question is what was his notion of man which underlay it? . . A As one reads the synoptists, there cannot be much doubt that Jesus, in his few months of public utterance, proclaimed some kind of a social gospel. It is true that he was primarily concerned with individuals rather than organizations, but equally true that he selected and trained these individuals as a sort of charter members for a society soon to be. It is true that it was thus the spiritual redemption of men and women, not the improvement of existing institutions, for which he labored. But that was because he regarded those present institutions as essentially hopeless and about to perish, not because he did not have the vision of a better and perfected state. As a matter of fact, he did live for a new and purged society. So while by the very nature of his genius he was not so much a reformer as a revealer, not an agitator with a plan, but an idealist with a vision, nevertheless it was a social vision and a group salvation which he foresaw." For a bibliography on this contrcversy, see Hastings, Encyclopedia of Religion and Ethics. 
Utopia of Jesus-his vision of a perfect human society, on which he bade his followers fix their gaze, and to the realization of which they should consecrate their lives. And to be vital social religion must have such a concrete social ideal.

But this social ideal of Jesus is not a cut and dried formula for a fixed social order-for a static human world. It is rather a mere outline, based upon fundamental social principles, to be filled in by the intelligence according to the human needs brought about by special situations. And in this it accords with the requirements of social science. It makes the work of social science, in order to fill in details and to determine methods and standards in special instances, not an adventitious and external aid to social religion, but rather an indispensable, vital part. To ascertain by careful investigation the needs of men in their economic, political, and intimate social life thus becomes a necessity of religion. For such investigation must furnish to social religion guidance in all the special problems of human life and alone can render religious values concrete and vital. Obviously, a social religion must concern itself with ends rather than means, and the evaluation of the latter must be left to science. Obviously, too, a social end or ideal should be elastic enough to leave room for definite knowledge to fill in the details. It should be a vision of vitalizing principles rather than of a definite organization; and such was Jesus' vision of the kingdom of God.

Just what social science indicates of the specific organization needed in our day in the family, in industry, and in political life to realize the Christian ideal, we shall consider in the immediately following chapters; but one 


\section{6}

\section{THE RECONSTRUCTION OF RELIGION}

constant implication of our argument remains to be rendered explicit. And that is, that the perfect human society which social religion aims to create must necessarily bo a world-wide society. The events of our day show clearly enough that no particularistic society, confined to one people, country, or race, can live and perfect its own life by itself on our globe. The very idea is self-contradictory and facts make it impossible. Any ideal social order that is to endure must be developed on a world-wide scale. It follows that a social religion must be a missionary religion, carrying enlightened social values, social patterns, civilization as fully as it has developed, to all peoples. It was no accident, therefore, that Jesus, if his religion was truly social and humanitarian, as we have argued, commanded his followers to go and make disciples of all nations. ${ }^{1}$ Neither is it an accident that historical Christianity at its best has always been a missionary religion. Whatever may have been the mistakes of Christian missions in the past, as long as the condition of the world remains as it is-with races and peoples alienated and misunderstańding each other-a positive social religion must continue to exalt missionary effort; for its ultimate objective must be a redeemed world, and this cannot be obtained without the teaching of social and religious truth to all peoples and the illustration of that truth by personal service and sacrifice. Social religion with its passion for the redemption of mankind would suffuse the whole religious life accordingly with a missionary spirit; and this, too, would be the spirit of Jesus.

Social religion would, in a word, make it the conscious end of all men's lires to have a share with God in the

${ }^{1}$ While many critics regard this command in the first gospel with its variant in the second as interpolations, yet they must have been a part of the early Christian tradition and would seem to go back to some probable sayings of Jesus. 


\section{ESSENTIALS OF A SOCIAL RELIGION 187}

building of a world. Not personal pleasure or power, not mere self-development or self-culture, but the creation of an ideal human world would thus become, if it were accepted, the controlling aim of all men's endeavor. ${ }^{1}$

1 Compare the statement of Professor Hocking (Iuman Nature and Its Remaking, p. 425): "The destiny of the human will is to cooperate, in some degree of present awareness with the central power of the world; and so far to perceive in present experience the quality of 'union with God.' In their complete meaning our human actions ... are creative in an actual, but unfinished world." 


\section{CHAPTER VII}

\section{RELIGION AND FAMILY LIFE}

A ReLigion adapted to the needs of modern life must have a positive and unequivocal doctrine concerning the family. If the first business of religion is the production of men, then its first concrete social task must be the construction of a family life which is capable of producing fully socialized individuals. Just as the primitive Christian church found in its attempt to reconstruct its world that its first task was to create a stable, moral family life, so social religion to-day in reconstructing our world must begin with this primary group. As the reasons for this are not always appreciated by the social and religious thinkers of our time, let us see briefly what they are.

Professor Charles Horton Cooley's doctrine of the function of primary groups in human society ${ }^{1}$ is almost as important in modern social science as Darwin's doctrine of evolution by natural selection in modern biology. Professor Cooley shows beyond a doubt that what he calls "primary groups" are the primary builders of human social life. By primary groups he says he means the simple face-to-face groups which are characterized by intimate, personal relations, such as especially the family and neighborhood. These groups are primary, he shows, not simply because they are primitive and universal forms of human association, but because they are the primary

- Social Organization, Chapters III-V. 
builders and bearers of the social values of men everywhere and in all ages. They are this, first of all, because they are the primary socializing agencies. They first stimulate and call forth the expressions of the social instincts; they first build up habits of co-operation; they first give rise to social consciousness. It is in the family in particular that the individual first learns what social life means, gets his earliest development of social impulses and habits, and first learns to say "we." Moreover, in all stages of social evolution since human life began, these primary groups have been the bearers of all social traditions. In them the child learns the first language and with his language he gets his whole social inheritance in a spiritual way. He receives especially from his family his ideas, beliefs, and standards concerning industry, government, law, art, morals and religion. In brief, he receives from the family life practically everything which makes him a man as distinct from a brute; for human culture, or civilization, as we have already seen is a complex built up of acquired habits and these habits are intermediated and controlled by a mass of ideas, beliefs, and standards, which make up social tradition. Inasmuch as the primary groups are the chief carriers of this social tradition, they are also the chief carriers of culture or civilization. They are usually carriers, moreover, of the appropriate customs which express the various traditions, and hence they impart the social tradition to the child, not in an abstract, intellectualistic way, but as part of a living, organic whole, oftentimes with social compulsion as well as with social illustration.

The consequence is that the child gets his main social education-his fundamental social attitudes and valuesin the primary groups. Primary groups must accordingly be regarded as the most important educative agencies 
of human society, so far as the social character of individuals is concerned. This they must doubtless continue to be, for they must always furnish the immediate social environment of individuals, and it is this environment which is more largely responsible for the social character. of individuals than all other factors combined. This is especially true of the family; for it furnishes the immediate environment of the child during its most tender and plastic years. It is, moreover, the natural environment to which the race has become adjusted through thousands of generations and to which all the child's instincts and capacities are adapted and most readily respond. In a word, science finds that the family is the normal environment of the child and that there is no adequate substitute for a good home.

If the first concern of religion is the production of men, then social religion would be supremely interested in the family, even if there were no deeper reason than its moulding of character in the young. But there is a deeper reason; and that is that the family life is the original fount in society of altruism, of love, which becomes the main content, as we have seen, of ethical religion. It is in the family that the child develops his altruistic instincts, learns what love means, and, if the family is normal, acquires habits of service and self-sacrifice. Family affection, in other words, is the natural root of altruism in society at large. The amount of altruism in society, therefore, has a close relation to the quality of its family life. ${ }^{1}$ But upon altruism depends largely both social order and social progress. We cannot maximize

1 For elaboration, consult the author's text, Sociology and Modern Social Problems, 1919 Edition, Chapters IV-VIII, and the references there cited. 
co-operation among men unless we can increase their good will as well as their intelligence. Hence religion's interest in the family must be proportionate to its interest in altruism or good will. Family affection is the indispensable root of social religion as well as of altruism.

The close connection between the family life and religion among practically all peoples is, therefore, not an accident. Both are concerned with the socialization of the individual, that is, with overcoming his natural egoism. While the family as a purely natural group does this in a very limited way, and while social religion attempts to do it in a universal way, this should not obscure the fact that the very values with which social religion works have their origin in the natural affections developed by the family. If these values will not work in the family life, they surely will not work in society at large. It is useless to teach universal love and good will and the maximization of co-operation if these cannot be realized in the face-to-face group which gave them birth. The interest of social religion in the family is not an interest in some remote source of its ideals, but rather in it as a living generator of altruism even though still for the most part to be perfected.

However, that the family was the original source of the chief social values which religion exalts is a fact of the greatest social and religious significance. Social religion obtained its very concepts, its "patterns," from the family life. It is the great merit of Professor Cooley's doctrine of primary groups that it has revealed clearly to us the original sources of our social ideals. Professor Cooley has shown that the pattern ideas for all essential human relationships come from the experiences and satisfactions of primary groups. It is especially the family which by its very structure and relationships has furnished the 
main moral patterns for society at large. ${ }^{1}$ Such ideals as love, service, self-sacrifice for the sake of service, brotherhood, motherhood, fatherhood, obviously have been derived from experiences in the family. Civilization has taken these patterns and attempted to make them work also in the larger groups of men. From one point of view all human history has been a struggle to transfer the altruism and solidarity of the family when at its best to successively larger and larger groups of men. The ideal of social unity, as Professor Cooley remarks, has been the mother of all social ideals; and social unity was first realized in the family.

In brief, the family life has always been social life at its maximum. In it human association has been, and always will be, at its maximum intensity. In it are generated both the forces which make for good and those which make for evil in our social life. Controlling as it does both the birth and rearing of children, it necessarily has the chief part in socializing the child and in giving him his social traditions, standards and ideals. In fact, the family not only reproduces the race, but it reproduces human society and human culture. Within it are continnally renewed not only life itself, but the very ideals and values by which men live a human life. It is the perpetual fountain of youth for the idealism of the race. Idealistic social religion especially gets from the family the ideals, the very goals, which it sets before men to realize in their relations at large. That there is an upward urge in the family life when normal is evidenced, therefore, by the fact that it has furnished the main patterns for civilization and for religion.

Thus the family has been truly the cradle of civilization.

${ }^{2}$ See p. 207. 
It has furnished the very ideals which men have striven to realize in their wider social life. Religion has found in it the values which it seeks to universalize. This is true, especially, in the case of both Judaism and Christianity. [Judaism, as we have seen, got its lofty moral tone from the projection, idealization, and spiritualization of the values found in the ancient Jewish family. The concepts and phraseology of Judaism can, indeed, be understood only through understanding the ancient Jewish family. Christianity only carried the process a step further, universalizing such concepts as fatherhood and brotherhood, and such ideals as love, service, and sacrifice. Historically and psychologically the intimate relations between the family and ethical religion are, therefore, necessary and inevitable. Destroy one and sooner or later you will have destroyed the other.

It follows that a normal family life for all men must be a prime object of a scientific social religion. Yet what is the condition of our family life? Nowhere have the pagan and destructive forces of our civilization had a more disastrous effect. ${ }^{1}$ Marriage and the family have tended more and more in certain classes to become mere matters of individual convenience. Taught by the modern romantic novel, the modern sex drama, and the modern newspaper, young people have come more and more to regard family life as something for personal gratification and for personal pleasure. Self-gratification rather than social conservation has been made the end of the family life. Nothing could illustrate the essential paganism of our civilization more clearly than the widespread prevalence of this attitude toward the family. Our "mores" with reference to marriage and the family are individual-

${ }^{1}$ See also the statements in Chapters I and IV. 


\section{THE RECONSTRUCTION OF RELIGION}

istic, they are not socialized. They are not even democratic; they are rather anarchistic.

The attempt to build our family life upon a basis of self-interest and personal happiness-that is to say, upon selfishness-has, of course, been a failure. In the countries where divorce is free, as in the United States, the number of divorces grows by leaps and bounds, until unstable families threaten at no distant date to predominate. In 1916 there were 112,036 divorces granted in the United States, but the homes whose bonds were practically dissolved and whose life disintegrated by our pagan mores in the family must have been nearly as many more. In some cities and states there is already one divorce to every two marriages. In 1916, it is reliably estimated, there were more than 150,000 children involved in these divorces; and as every child needs a good home and two parents, the social welfare of many children must have suffered. Yet some wonder at the increase of juvenile delinquency and adolescent crime among us!

Not convinced by facts like these that personal happiness is an inadequate basis for the family, we have those in plenty who would definitely abandon the standard of permanency in family relationships and permit divorce to become a private act brought about at any time by mutual consent. Thus the ideal of permanent monogamy itself appears endangered by our individualism.

Scientific social religion must meet an issue like this. It cannot dodge it. While the family is not an end in itself, any more than any other social group, yet it is, as we have scen, indispensable to humanity. If social religion is to teach the service of mankind, and the full consecration of individual life to that service, then it must condemn unequivocally selfish standards of happiness in 
the family. It must ask that the larger life of humanity be not impeded in its flow through this institution, and that the family life be such as to contribute to that larger life. It must, in a word, demand that the family life become fully socialized. To this end it must seek (1) the subordination of material conditions to the social and spiritual values of the family; (2) the subjection of the animal nature of man to the service of mankind through family relations; (3) the basing of the family life itself upon some specific form of unselfish service which is peculiarly its own.

(1) The present instability and demoralization of our family life is undoubtedly rooted in the relation of that life to material conditions. We have allowed material conditions to dominate the family. Business and industry, formerly developed as adjuncts to the family, have now become more important in the eyes of many than the family life itself. Not only do private employers and industrial corporations put interests of their business ahead of the domestic interests of their employees, but even families themselves in many cases regard their business life as much more important than their home life. Business and industry, in other words, have come to be dominating interests which do not recognize their reasonable and socially necessary subordination to the family for the sake of the higher interests of society. The requirements of the family for the good birth and proper rearing of children are sacrificed for the sake of business or industry. Thoughtless employers with self-interest standards in their business rarely inquire into the home life of their employees. Indeed, the wages which they pay to their male workers are often quite insufficient for the worker to maintain a home and rear a family, and even in some cases tend to become merely the wages of 
single men. The heartlessness of modern business, and particularly of some industrial corporations, in employing men, women, and children under such conditions and for such hours and wages as tend to destroy their home life is one of the blackest stains upon modern civilization. Social religion must recognize this, and must insist that industrial and business considerations shall be subordinated to the considerations of the welfare of parents and children in the family group. The labor of immature children outside of the family, whether upon the street, in factories, in shops, or in stores, under such conditions as impede their physical, mental, and moral development, must especially be fought by social religion as an unmitigated evil. The drafting of children of school age into industry is perhaps as clear an example as we have of the materialism and paganism of our civilization. Yet millions of children in Christian nations who should be in school are thus drafted and made parts of the industrial machine.

The labor of women also outside of the home if not carefully safeguarded may easily become subversive of the higher values of the family. If they are permitted to labor under such conditions that normal home life becomes practically impossible, then again the family is sacrificed to material considerations. Their hours of labor, their conditions of labor, and the kind of labor which they are permitted to do should all be regulated by the consideration of the requirements for a normal home life. Even in the case of young unmarried women, this should be so; for while they may have no specific home duties, yet their life should not be such as to unfit them for the home and the family.

In all cases it must be insisted that the duties of the home are paramount to those of business. Adequate 
wages, reasonable hours, wholesome conditions of work in industry are not so much the demands of the selfinterest of the workers, as of the socialized conscience of all men who see human values in their right relations; for, in a word, they mean that our business and industrial life should be organized about our family life rather than our family life about our business and industry.

Social religion should create a public conscience in every community that will demand that not only industry but all other material conditions should be such as to favor the upbuilding of family life. Scarcely less important than the relations of the family to industry are, for example, housing conditions and sanitary conditions. Our cities too frequently have not been built for homes, but for financial returns. In their poorer quarters families have been crowded together under such conditions that their children have had practically no chance, condemned, in effect, by their environment to lives of misery, vice, or crime. Social religion will seek to correct all this, not by rescuing a few individuals, but by preventing such conditions by providing model dwellings, building "garden cities," and so far as practicable making possible the ownership of individual homes by families of all classes. These material things and all others which social science finds to be necessary or desirable for normal family life, must become the vital concern of a social religion which seeks to create men through the instrumentality of the family.

(2) Equally important is the subjection of the animal nature of man to the requirements of a normal family life for the sake of the higher interests of society. Men and women who suffer from the encroachments of business and 
industry upon their family life usually readily admit that the family should be put ahead of such material interests. But these same men and women sometimes fail to see that their own animal impulses should also be subordinated to the requirements of the family. Sex and sex life are made so much of in our literature and on our stage that the gratification of sex impulses looms in many minds, if not as the chief value, at least as the most imperious need of life. Yet to all who have not been swept off their feet by pagan individualism, and its resulting animalism, this appears as one of the most stupid blunders which sociological ignorance permits to exist. While the family is founded on the biological fact of sex, its main function is not the gratification of sex impulses. That is a shortsighted illusion indulged in only by those who are destitute of social understanding. Social science finds that the chief function of the family, as we have already said, is to reproduce both human life and human society with all its values. Sex is the indispensable means for the performance of this function; but as soon as we make it the end, we revert to a life which is lower even than that of the brutes.

Unscientific ethical religion has long seen this, and for ages has attempted the control of sex impulses. But too often it has adopted a merely negative and repressive policy toward the sex element. ${ }^{1}$ A scientific social religion, while aiming not less at control of this element, will adopt a positive and constructive attitude toward it. This is the more easy, because science finds this element to be the very organic foundation, not simply of the

${ }^{2}$ Christianity has often been accused of taking this attitude, and it certainly has often been the attitude of certain branches of the Christian church. Even Carpenter, however, who repeats the charge, is forced to admit (Pagan and Christian Creeds, p. 180) that there is nothing to show that Jesus himself adopted any such attitude. 
family, but of social life itself, and hence of all the higher spiritual life of man. It has been a favorite theory of certain writers in the psychology of religion that most of the phenomena of religion spring from sex and sex impulses. Science finds at least this much truth in such theories, namely, that sexual reproduction is undoubtedly the chief organic basis of the social process and its resulting co-operation and altruism. However, it is not mere sex, but rather parental care, ${ }^{1}$ which is the foundation of intimate social life and of altruism. From this root, too, springs, as we have already seen, the social phases of religion.

Nature has used sex, in a word, as a chief means for the higher evolution of life. Surely human intelligence also can make sex to serve the higher interests of the race. Science shows clearly enough how this can be done. It is by controlling sex impulses in the interest of a sane and wholesome family life. As long as repressive control was regarded as an end in itself, it was impossible for religion to take a constructive attitude toward sex. But as soon as such control is seen to be for the sake of the family and for the service of humanity through the family, then controlled sex impulses are welcomed as a basis of family affection, and the social religious ideal becomes, not celibacy, but a pure and lasting family life. Chastity for both the married and the unmarried takes on a new meaning - a social meaning-and it is seen to be preeminently the virtue by which men and women can live together on a human plane, and it is honored as such. As a necessary social virtue it is held to apply to both men and women equally. The whole social life is purified

${ }^{1}$ See Sociology and Modern Social Problems, 1919 Edition, p. 95; also Introduction to Social Psychology, p. 37. See p. 204 of this chapter. 


\section{0 THE RECONSTRUCTION OF RELIGION}

and ennobled, because sex is subordinated to the family, and not family life to sex. In a word, sex is made to serve the higher values of the social life instead of being merely repressed. Thus social religion as well as social science will find in sex a potential basis for the bighest social values.

Such control of sex impulses in the interest of the family will mean their control in the interest of the child and the race. Modern biology has shown the extreme importance of heredity to man; and obviously the control of heredity must come through the control of sex relations. The modern science of eugenics is as far from endorsing promiscuity in sex relations as ethical religion itself. Lax standards of sex morality would make impossible the realization of eugenic ideals. Eugenics demands that we control marriage in the interests of the race, but this in turn implies the control of all sex relations. If eugenics is ever to become practical, it can be only through the development of much higher standards of sex morality than we have yet attained. For it implies the triple control of sex in the interest of the family, the child, and the race, though upon rational analysis these are seen all to mean the same thing. It implies that marriages shall be based upon the good health, good character, and the intelligence of the two stocks concerned. It implies that families that have these socially valuable qualities as hereditary endowments and have in addition a normal environment should feel a social obligation to produce more than their proportion of children. It implies negatively that those who are not normal in their hereditary endowments should refrain from marriage, and that those who for any reason do not marry should lead lives of continence. Finally, eugenics implies that all who are so ab- 
normal that they cannot be controlled by the moral standards of society should be segregated in institutions and supported at public expense.

It is a counsel of perfection which modern science has given us in the doctrines of eugenics; but like all such counsels it is socially valuable and is obviously closely allied with idealistic social religion. If eugenics were ever made the basis of a code of minute legislative prescriptions regarding marriage and reproduction, doubtless it would become an intolerable tyranny. But as the basis for social ideals regarding marriage and the birth of children, it is invaluable. Social religion, not less than eugenics, is interested in securing wise marriages and in making sure that every child is well-born. Social religion, too, should emphasize the social service which parents render to society in the birth and rearing of normal children. It, too, should set up the ideal that the physically strong, the intelligent, and the economically fortunate families should have more than their proportionate share of children, because the children born in such families will obviously have the best chance to grow up into useful members of society. Thus a truly social religion will encourage marriage and parenthood among the socially normal. It will insist that no service to society which men ordinarily render is greater than the birth and rearing of normal children in a normal home, and that this is the production of men in the primary sense. It will make the birth of children in the family welcome in proportion as there is health and strength and economic means to give them a fair start in life, and it will condemn the selfish individualism which shirks the obligations of parenthood. Finally, it will seek to create in the young a eugenic conscience which will safeguard marriage and the birth of children. Only thus can the ideals of 
eugenics stand any chance of realization, as Sir Francis Galton, the founder of the movement, himself recognized. Here again we see the essential identity of interest of applied social science and social religion.

But a eugenic conscience and eugenic ideals are not enough in themselves to assure that sex impulses will become socialized and used always and only for the good of mankind. In this age of medicinal prophylacties and widespread knowledge of means of preventing conception insidious temptations present themselves to many, and the broader view is necessary. To the ignorant vice and immorality appear to have been rendered "safe." Unless the whole level of sex life is lifted to a rational social plane and sex is made to contribute to the higher social values-to the nobler affections, sentiments, and emotions -there still is danger of sex impulses brutalizing character and conduct.

To avoid this danger social religion must unite with social science in demanding scientific ethical instruction for the young in all matters pertaining to sex. Such instruction, if vitally related to social obligations in the family and in the community, would save the young from many pitfalls. Ignorance in this matter, as in other social matters, is probably one of the chief sources of present social evils, and in no case is it a protection to society. But such instruction, to be socially effective, must be rightly given with the proper ethical background. Sociology rather than physiology is the basis of the higher sex moralities. It is absurd to think that sex morality can be inculcated upon the basis of selfishness, since no social order, as we have seen, can long endure upon such a basis. The control of sex impulses must rather be sought through the development of social conscience and an altruistic social spirit in the young. Hence idealistic social religion 
should be joined with science in all sex education. It alone can give an enduring motive for the self-control which will result in the highest social control. If religion sought the aid of social science, and if science sought the aid of social religion, this age-long problem would no longer prove impossible of solution. The purity of life already attained by the more highly socialized elements of society would be found to be possible for all normal men and women. The venereal diseases which so disgrace our civilization would be more easily stamped out than the measles; for chastity in both men and women and a resulting pure family life would be found to be their effectual preventives. An enlightened social world two centuries hence may wonder, indeed, why we had not already accomplished this; and the only answer is that both our science and our religion are still too imperfectly developed on the social side.

(3) But most of all, must social religion demand a complete ehange in our "mores" with reference to marriage and the family. Instead of regarding these as matters of individual convenience, social religion must teach that they are social responsibilities and also opportunities for human service. The whole family life must be put upon an ethical instead of a selfish basis. Marriage itself should come to symbolize, both in the minds of the contracting parties and of the community, full consecration of life to the service of the race. Its basis should be not mere fancy or passion, nor even romantic affection, but an unselfish love which leads to a full and free consecration of life to the promotion not only of the welfare and happiness of the parties themselves, but also of society. The bonds of such a marriage must be not fear or coercive authority, but love and respect and the sense of social 
obligation. If the ideal of the service of humanity is to dominate marriage and the family, however, society in general must value the service of humanity through marriage and the family, and must make it possible for each normal individual to have such a family life.

But such a high social valuation of marriage and the family cannot be attained and kept unless there is some specific service which the family renders to society that is of the utmost social value. What is that service? Is it to the community? Indirectly, yes; but it cannot be to the physical, economic, and moral welfare of the community at large, because other institutions could perform such service better than the family. Is it simply to minister to the comfort, happiness, and welfare of the married pair? This would be, however, such a narrow and selfish service that it would warrant no higher social valuation of the family than is already customary. Indeed, our low valuation of marriage and the family is precisely due to the fact that so many people consider these to be institutions whose chief end is to serve private individual comfort, happiness, and welfare.

But social science reveals that the chief end of marriage and the family is the child. The chief service which the family is called upon to render to society, accordingly, is the service of the child. The child, in a word, is the center of gravity in normal family life-the child that is born or that may be born. It is the child and its needs which lifts marriage and the family from the basis of selfishness and makes it possible to put them both upon the basis of the widest possible service to humanity. For the child stands for society and the race. The service of the child is preeminently the service of the race. If humanity is to continue to live and to work out a better 
future, the welfare of every child is of the highest importance.

In the great structure of civilization the one concrete problem which looms everywhere as of supreme importance is the problem of child welfare; for there is opportunity to improve human life only as new lives enter to make a fresh start. Child welfare is the central problem of civilization and social science shows that it is impossible of solution without a normal family life. It is this which gives the family, as we have already seen, its commanding importance in human society. The child's heredity, its physical care, its early mental education, and its moral character are all largely determined by its family life. The attempt to work out the problems of child welfare without reference to the family, social science finds, is as absurd as the attempt to make perpetual motion without a perpetual source of energy. The first condition of child welfare is a normal home life, for the reasons which we pointed out at the beginning of the chapter and because all other child-care agencies which may be devised by philanthropy are inadequate substitutes for a normal home. If humanity is to progress, therefore, the whole of human society has to be so organized as to maximize the number of normal homes in which children can be properly cared for and given a fair start in life.

Social religion, accordingly, would put the little child in the midst. It would make our social values concerning marriage and the family center about the child. All the questions which men raise regarding the family would then find answer. It would be evident, for example, that only a stable home, one which is characterized by enduring, unselfish love and loyalty can best serve the interests 
of the child. It would be evident that the atmosphere of the home should be one of altruism, illustrating in the mutual devotion of its members that spirit of unselfish service which is the most effective means of educating the child socially and religiously. It would be evident that the family should be dissolved only when the interests of the child demand such a dissolution. Upon such a basis there could be little talk of divorce being in accordance with ethical ideals. It would be recognized as like surgery in medicine-an attempt to deal with a desperate situation which cannot be dealt with in any other way than by a last-resort remedy.

But with a truly social religion men and women would no longer think of entering upon marriage with the idea of possible divorce; they would look upon marriage as a religious, because a necessary social, bond. Nor would they ask for the right of divorce by mutual consent. They would recognize that the rights of society and of the child are in all cases paramount. Nor would couples to whom no children happened to be born ask for any different treatment than those with children. They would recognize that social standards have to apply to all alike and cannot be based upon those exceptional cases in which there are no children in the family either by birth or by adoption. In short, a social religion in harmony with scientific social knowlcdge would reinstate the ideal of the family as a lasting union, a community, whose bonds should be broken only by death.

It would do so not only because the responsibilities assumed in family relations normally end only with death, but also because sound social science finds the social value of all institutions not in their immediate effect upon personal comfort and happiness, but rather in their educative influence upon personality. And it is evident that if we 
want a social personality characterized by tolerance and good will-that will minimize conflict and maximize cooperation in all the relations of life-we must have a stable family life as our standard. Only with such a family life can there be the highest possibilities of developing altruism in the character of the individual. Only such a family life can help to build a better human world which will be increasingly based upon love. While the great concrete end of the family is the service of the child, the satisfaction of its physical wants and the development of its social character, yet this implies that the larger social purpose of the family is the creation of an ideal social world. It is because it is the primary agency for the accomplishment of this purpose that social religion must have such a supreme interest in the family. Without the family the flame of spirituality could not be kept burning in our world; and in proportion as the family is permeated by unselfish love, and so is made pure and stable, the flame of spirituality will mount higher. ${ }^{1}$

It is scarcely necessary to add that in stating the doctrines regarding the family which social science requires of a social religion, we have outlined what is essentially the Christian ideal. The religion of Jesus is characterized by the central place which it gives to the child and to the family. It is, indeed, as we have seen essentially an idealization and projection of the social values experienced in the family, such as love, service, sacrifice, brotherhood. These values could scarcely serve as patterns for the relations of men at large if the family failed to illustrate them. Love as a social principle finds the initial

${ }^{1}$ See Professor Felix Adler's Marriage and Divorce, especially Chapter I. It is noteworthy that this clear presentation of the Christian ideal of marriage and the family is made by one outside of the Christian church. 


\section{THE RECONSTRUCTION OF RELIGION}

test of its practicability in the family group, and this Jesus seems to recognize when he demands that husbands shall not put away their wives, or wives their husbands, and marry again. The relations of husband and wife, he seems to teach, are not different in principle from the relations between parents and children. They are provided for in the nature of things and involve responsibilities which when once assumed cannot normally be laid aside.

It is Jesus' teaching concerning the child, however, which helps us to understand clearly his teaching concerning the family. He makes the child the center of gravity in his system of concrete values not less clearly than does modern social science. So great is the value of the child, he tells his disciples, that an offense to a child is among the worst of sins, while the slightest service, even the giving of a cup of cold water, is a religious act of the highest significance. He tells his disciples further that whoever receives a little child in his name receives him, and that to children belongs the kingdom of God. It is no wonder with such teachings that the early church took up child care as one of its primary social functions. Clearly also these teachings of Jesus concerning the social and spiritual importance of the child must be correlated with his teachings concerning marriage and divorce. These latter have often been interpreted as resting upon ethical rigorism, but when they are correlated with his teachings regarding human relations in general and regarding the child in particular, they are seen rather to be an expression of his religious humanitarianism.

However, it is not our purpose here, or anywhere, to attempt a critical interpretation of Jesus' teaching, but rather merely to point out that a humanitarian religion based upon the principles of social science is funda- 
mentally in harmony with the Christianity of the Gospels. The family is society in miniature. If men cannot be socialized in those primary relations of life which it represents, it is idle to think that they can be in the wider, more complex relations of larger groups. The ideals of love, loyalty, service, sacrifice, forgiveness, and conciliation must be found adequate controls over the behavior of men in the family if they are to be found practicable in the larger relations of life. The indispensable preliminary to a Christian society is a Christian family life. 


\section{CHAPTER VIII}

\section{RELIGION AND ECONOMIC LIFE}

A RELigion adapted to the needs of human life must have a scientifically sound and unequivocal doctrine concerning the material conditions of life-especially concerning those conditions under which men live and work, that we term "economic." Social religion must fearlessly oppose anything immoral or unjust in the economic system in which men must work and live, because such evil will make impossible the realization of a satisfactory moral character in individuals and of a satisfactory order in society. Injustice in these fundamental conditions of life is bound to have effects in the religious and moral life. While there is no scientific warrant for a doctrine of complete economic determinism, yet all progress in the social. sciences has served to reveal more and more clearly the importance of the economic element both in individual and in social life. The social environment as a whole, both material and spiritual, science shows, plays the preponderant part in the determination of the moral character of the mass of individuals. Now, economic conditions are the chicf material elements in the social environment. It is idle, therefore, to think that religious ideals can be realized if economic conditions hostile to those ideals are permitted to exist. ${ }^{1}$

${ }^{1}$ It surely needs no argument to show, e.g., that food is so fundamental in human life and the conditions under which it can be secured are so precarious and complicated that religion must play a leading part in controlling these conditions if it is going to redeem the lives of men. See above p. 164. 
Now if the aim of social religion is the production of men, of the values connected with human personality, then one of its first tasks must be to help devise a system of business and industry, of work and material reward, which will be in harmony with that aim. Religion dare not be merely a system of abstract ideals and values out of relation with real life. That, as we have seen, is one of the causes of its social failure. It must be a set of practical attitudes toward practical problems. It is idle to talk of the kingdom of God, of an ideal social order in which the divine will is realized, as long as an essentially pagan economic system persists. The economic life must become suffused with the highest spiritual values; it must be dominated by humanitarian ethics, if ever such an order is to be realized. Such an economic life is not impossible. Yet it can become general only if the economic system be such as to make possible a normal life for all, only if it emphasizes the values in men rather than the values in things, respects personality, and serves the physical and moral welfare of all. Such a system must manifestly be not only in accord with the principles of liberty and justice, but such as to maximize co-operation and to minimize hostility and conflict among all men. It is clearly the duty of religious people to make the realization of such an economic order a prime object of the practical religious life. ${ }^{1}$

${ }^{1}$ Steps have been taken in this direction by leading denominations by the adoption of "The Social Creed of the Churches" and similar declarations (see appendix). Concerning these, Professor Ward (The New Social Order, p. 350) well remarks: "The meaning of these programs has not yet been perceived by millions of persons belonging to the organizations which have written them." This is seen in such incidents as that at Pittsburgh, Pa., in 1920, when the Y. W. C. A. was refused support by business men's organizations because it had adopted "The Social Creed of the Churches." In general, religion has been too "other-worldly" to concern itself until very recently with economic conditions. See Chapter III of this book. 


\section{THE RECONSTRUCTION OF RELIGION}

Yet no phase of life has come less definitely under the influence of ethical religion than the economic. It is in the economic sphere that we expect selfishness to be most in evidence; and it was the observation of the economic life of the nineteenth century which built up the philosophy which proclaimed that self-interest rules all men in all things, and even that action upon any other basis than self-interest is inconceivable. It is in the economic; sphere, in a word, that the baldest selfishness, greed, and inconsiderateness of others is to be found. We have already seen how even at the present time, in a part of our business and financial world, predatory pagan standards prevail almost as they did before the Christian movement. began. ${ }^{1}$ Rich and poor, employer and employee, alike too often hold that they are entitled to all they can get and can keep, regardless of the service rendered. Instead of seeking only just compensation for service rendered, both working man and business man too often seek to get as much as they can and to give as little in return as possible. Indeed, it is not too much to say that the passion to get "something for nothing" dominates modern economic life, in the sense that it gives color and tone to its most characteristic features.

In a word, we have an economic system, as one able economist has pointed out, which emphasizes rights, privileges, and rewards, instead of functions, obligations, and service. $^{2}$ The result is that instead of a fair exchange of

1 See Chapter IV.

- Tawney, The Acquisitive Society, Chapter II. Similarly, Professor Small has pointed out that in the economic process as described by the classical economists-and they were describing actual factswealth was the end and men were the means. While economic theory has become more humanistic, economic practice too often has remained as the classical economists described it, whieh is proof, not that they were right in their theories, but that we are still wrong in our fractices. 
goods and services being sought by all, the greatest possible private gain is usually sought; and this works out in practice, not in that equal exchange of services which we have described as the very essence of happy and harmonious social living, but in a tendency to exploitation. Naturally it is the weak who get exploited under such circumstances. The employer who makes private profit his standard considers it merely "good business" to hire labor in as cheap a market as can be found, and to pay the laborer only what is barely necessary. Regarding labor as a "commodity," he naturally treats the laborer as a "hand," and regards him simply as a means to the production of so much wealth. Similarly the merchant or corporation that makes private profit the standard considers it fair to get out of the consumer as much as possible.

The consequence is that society is divided not simply into normal economic classes, but into abnormal classes, exploiters and exploited, who regard each other with suspicion and hostility. Our civilization, as a further consequence, is forever on the verge of class war, and even at best is so divided into distrustful and egoistic groups that no high efficiency is possible. Even at the present moment when our world so sorely needs to be united in the tasks of restoration, rehabilitation, and reconstruction, instead of being united in the work of life, over one-half of our potential energy is dissipated through misunderstanding, mistrust, and conflict.

Like slavery, the system is equally bad for the privileged and the non-privileged. The economically fortunate often live luxuriously, and without serious labor of their own, upon the proceeds of the labor of others. Hence, they too frequently develop selfish, arrogant, unsympathetic social attitudes, and devote themselves to lives of 


\section{THE RECONSTRUCTION OF RELIGION}

sensuality and self-indulgence. The man who labors, on the other hand, is too often degraded, not only because through exploitation, he remains poor and ignorant, but because he is in a class which is looked down upon and which has but little chance to rise. He either loses ambition to rise, or, accepting the materialistic standards of the rich, develops an envious, sullen, shirking attitude and renders the least service he can-if indeed he does not become a violent enemy of the existing order. It is thus that modern society has become a divided household.

Eminent economists and statisticians have often set forth the main economic facts of the situation. They have pointed out that even in the United States "two per cent of the population possesses the lion's share," that is, almost sixty per cent of the wealth, while "the poorest two-thirds of the people own but a petty five or six per cent of the wealth," 1 and nearly one-half of all families have no taxable property. Of the poorer half of the population, a large fraction (in the United States, at least ten per cent of the total population even in prosperous times) have not sufficient income to provide themselves with the necessities of life, and live constantly, as we say, below the poverty line. ${ }^{2}$ This is not surprising when we learn that "it is certain that at least one-third and possibly one-half of the families of wage earners employed in manufacturing and mining earn in the course of the year less than enough to support them in anything like a comfortable and decent condition." 3 Similarly we find

${ }^{1}$ King: The Wealth and Income of the People of the United States, pp. 80-82. This book is invaluable for the study of the problem of the distribution of wealth.

' Parmelee, Poverty and Social Progress, p. 105.

- Report Commission on Industrial Relations, Senate Doc. No. 415, 64th Cong., p. 22. 
that in 1915 careful study showed that more than onehalf of the families of the United States received less than $\$ 800$ as an annual income, although that amount was estimated by experts about the same time to be the minimum amount necessary to support an average family. While wages rose greatly during the war, especially in the skilled occupations, the cost of living rose so much that in 1919 experts estimated that the minimum amount necessary to support a family of five was, in many places in the United States, above $\$ 2,000$ a year. The rewards of capital meanwhile had so increased that by 1917 , the banner year for profits, capital received in profits, in addition to interest, more than twenty-five per cent of the entire amount added to the value of the products of industry by labor, though in ordinary times profits usually amount to less than half that per cent. ${ }^{1}$ The net result of the war seems indeed to have been to turn more wealth into the hands of the fortunate few, while the economic position of the masses, in the United States as well as in Europe, has probably been rendered more precarious.

Accompanying this poverty and low wages there have been often too long hours of work, the labor of children and married women outside the home, and much unem. ployment. It has been shown that the wage earners in the principal industries in the United States lose on the average from one-fifth to one-fourth of their working time during a normal year. If this is so, high wages by the day or the week may not look so high when the loss of time through unemployment is taken into account. In periods of industrial depression unemployment frequently rises to staggering proportions. During the summer of 1921 the number of the unemployed in the United States

${ }^{1}$ Friday, Profits, Wages, and Prices, pp. 124-130. 


\section{THE RECONSTRUCTION OF RELIGION}

was variously estimated to be from four million to six million. Much of this unemployment is simply due to industrial maladjustments in the relations of employer and employee. Indeed, a majority of the waste connected with our industrial system seems to be a direct result of the basis of selfishness upon which business is carried on. Strikes and lockouts, low wages and long hours, exploitation and sabotage, friction and bickering of every sort, are certain evidences at least that the spirit of co-operation does not rule in our economic life. And it is from these things that the greatest losses in time, in energy, in wages, and in productiveness in industry spring.

Indeed, it is not so much the poverty and inequalities produced by our present economic system which lead to its condemnation by the most thoughtful as the ineffciency and conflict which result from it. Says a leading economist," "There is one, and only one, test by which to measure the soundness of any movement in social life, in industry, or in politics. Does it make for peace or for violence? Does it extend the field of voluntary agreement among free citizens, or does it extend the field of authority? Does it enlarge the opportunities of those who inspire fear, or does it enlarge the opportunities of those who prosper through good will ?" Judged by this test, which we accept, our present economic system must surely be found wanting, for it breeds misunderstandings, hatreds, and violence. Moreover, fear more often than love is the motive to which it appeals, and too often it forgets to safeguard the liberty of the individual. In its ignoring of personality and of human brotherhood, in its too frequent denial of liberty and justice and social responsibility, in its emphasis upon self-interest, and in its scouting of love and of service for the common welfare

1 Professor T. N. Carver, of Harvard University. 
as possible and practicable economic motives, it is essentially a pagan system and must be fearlessly opposed as such by all who wish a Christian world, that is to say a world of peace, good will and universal co-operation.

No revolution in social and industrial organization will remedy the evils of such an economic system; for its evils are not external, but in its spirit and inner nature. Modern capitalism has often been accused of being pagan in its ethics, and the most searching, most impartial, most scientific investigation has practically substantiated this charge. ${ }^{1}$ Indeed we could not well expect it to be otherwise in our semi-pagan civilization. The problem is not one merely of a change in an external order. A change which is nothing less than climatic, as we have already said, is needed in our whole social and economic life if the primacy of human values in industry is to be effectively recognized. The whole spirit of our business and financial world must be changed-our economic "mores" as a whole must be transformed. Doubtless this means corresponding changes in our methods of business and in our industrial organization; but the change in the spirit and purpose of our economic life must come first, or else mere external changes may prove but a new means of exploitation. On the other hand, old forms of business and industry may make impossible the success of a new, more Christian, more humane spirit in our economic life. Evidently here, as everywhere in social life, changes in inner spirit and aim must be accompanied by changes in external methods and order if any lasting betterment is to

See Tawney (op. cit.). For a brief, dispassionate statement, seo Professor J. H. Tuft's article on "Ethics of Capitalism" in Dictionary of Religion and Ethics (published by The Macmillan Company, 1921). 


\section{THE RECONSTRUCTION OF RELIGION}

be effected. What then are the changes necessary? And how may they be brought about?

It is certain that while social science may indicate the means and even outline the concrete details of a new order, social religion-enthusiasm for humanity-must furnish the driving motive if ever such order is to be realized. The task is of such magnitude that it requires the combined resources of science and religion. Humanitarian enthusiasm and the ethical ideals which it inspires may guide up to a certain point; but adequate scientific knowledge can alone furnish the means of solving the real difficulties of the problem. Here we must agree with those religious conservatives who hold that religion has no right to meddle with social problems without adequate knowledge based upon scientific investigation of facts. We must agree because manifold experience in the past has shown that mere good intentions will not do. But on the other hand, social religion cannot stand aside when the welfare of human beings is at stake. Evidently there is only one way out of the dilemma, and that is for social religion to ally itself with science. Religious people can get the facts if they wish them, and any worthwhile social religion will insist that it is a supreme duty to secure the facts concerning every social situation which affects the welfare of human beings and to give them full publicity. The absolute dependence of social religion upon social science for concrete guidance here emerges. $R e$ ligion must take sides on questions which affect human welfare; but, when the question is a controverted one, it can do so intelligenlly only after the full facts are before it. Before social religion can guide aright, for example, in the great industrial and economic problems of the present, it must square itself with the facts of economic science, and build its program for the redemption 
of our economic life in accordance with scientific principles. The social ideal which religion sets up must be within the limits of the economically possible.

What then are the limitations ${ }^{1}$ which social and economic science impose upon the religious ideal? To discuss this matter fully would be to review all the principles of modern sociology and economics. It will suffice for our purposes to point out four limitations which science imposes upon ethical and religious ideals in their relations to the economic life. In the first place anything like pure communism is impossible in civilized society. Even so-called primitive communism restricted the progress of the peoples who practised it and was largely responsible for such peoples remaining in an undeveloped condition. In the complex conditions of modern society communism is much more impossible. Every experiment in a communistic organization of society for the last two thousand years has failed and the recent experiment in Russia can have no other outcome. The most elementary understanding of the principles of sociology and economics points to this conclusion. Individual functions and functioning, individual rights and responsibilities, division of labor, control over production and consumption, economic rewards and penalties, all presuppose private property in a complex society. Property and personality, in other words, are closely linked in their development, and so also property and civilization. Private ownership

${ }^{1}$ Broadly viewed, economic truths, of course, are not "limitations" upon social religion, but are rather aids in defining a practicable social ethics upon a basis of facts. They are, therefore, opportunities, if rightly utilized, for religion to be of the largest service to men. Strictly speaking, then, science does not place limitations upon religion (unless calling it from the world of dreams to the world of realities be a limitation), but comes to its aid by giving a basis of scientific facts and laws for a social ethics. 
in some sense has been, and is, as necessary for human society of any developed type as the private family. Societies in order to have any high degree of efficiency must harness about equally the egoistic and altruistic impulses of human nature. It has often been said that private property develops only the egoistic impulses; but it is evident that if rightly used it may develop equally the altruistic impulses. Idealistic morality, indeed, presupposes private property. Any one who has read the Ten Commandments carefully knows that prirate property is written in between their lines. ${ }^{1}$ In brief the institution of private property has been one of the foundations of all culture and of all progress, and the tradition of private property, purified of pagan abuses, must be preserved as one of the cornerstones of our civilization.

While communism is impossible on any large scale in our society, still this does not mean that something of the spirit of communism may not be necessary for the highest development of civilization. In the primitive communism of the Eskimo, anthropologists tell us, a whole village of Eskimo may perish from starvation but a single Eskimo never, because as long as any food remains it will be divided, when necessity demands, equally among all the members of the group. Surely something of this spirit must pervade every human group that is rightly organized and has the right standards of living. The private property which the Eskimo have (and they have considerable) does not prevent this in their case, nor should it prevent it in ours. Again, while communism as a form of economic organization is impossible, this does not mean that public ownership is thereby con-

1 Compare the similar statement by Professor Small in Between Eras from Capitalism to Democracy, p. 366. The book is a strong indictment of modern capitalism with a plea for the subordination of property rights to human values. 
demned. Public and private ownership have existed side by side through all the centuries of human history, their proportions varying according to the circumstances and needs of the social life, and they will doubtless continue so to exist. ${ }^{1}$ There may be a large place for public ownership even if communism is impossible. These questions will be taken up again later.

Another limitation which modern social and economic science places upon religious ideals is the perception of the impossibility of the abolition of social and economic classes. Classes exist in society not only because of the natural differences among men, but even more because of the necessity of the division of labor in any developed social life. Classes based upon artificial distinctions are to be condemned and cannot be justified by any of the facts of social science. But classes based upon natural differences in ability and talent or upon necessary divisions of labor in a complex social order are something wholly different. No civilized society has been able to dispense with such classes, and no civilized society possibly can. Equality of rights and opportunities is theoretically possible in society, but not equality of functions and rewards, unless we give a moral rather than a practical and economic sense to such terms.

The attempt to abolish economic classes in civilized society, in particular, is impossible. It is impossible because the fundamental economic classes are based upon the nature of human industry and its necessary division of labor. There must be, for example, the class of producers of raw materials, which roughly coincides with the

${ }^{1}$ See Ely, Property and Contract in Their Relations to the Distribution of. Wealth; also Property, Its Duties and Rights, by Professor Hobhouse, Professor Bartlet, Dr. A. J. Carlyle and others. 


\section{THE RECONSTRUCTION OF RELIGION}

agricultural producers, or the farming class. There must also be a class to work up these raw materials into manufactured products, which roughly in our society coincides with factory laborers. In any highly developed society there must also be a class who undertake and direct business enterprises, which class roughly coincides in our society, with the business men. Finally in a highly developed society there must be a class who render certain expert services and who have special charge of the higher interests of culture on its spiritual side. This class roughly coincides in our civilization with the professional classes. These four fundamental classes, which we may roughly call farmers, factory laborers, business men, and professional men, with other minor classes, every highly developed civilization must have. And the economic problem of our time is very largely how to adjust the interests of these necessary economic classes and to get them all to work together for the common welfare. The impossibility of abolishing such fundamental economic classes must be evident, but this surely does not mean that there needs to be conflict between them.

Another limitation which scientific investigation puts upon economic ideals in religion and ethics is the perception that for the present, at least, the economic problem is not one merely of distribution, but is even more a problem of production. ${ }^{1}$ If all the wealth of the United States, the richest nation in the world, were equally divided there still would not be enough for a good life with a proper standard of living for every family. ${ }^{2}$ The

'See Professor H. B. Gardner's address on "The Nature of Our Economic Problem," before the American Economic Association in 1919 (in the American Economic Review, March, 1920).

'According to the National Bureau of Economic Research, the average income per individual in the United States in 1913 was 


\section{RELIGION AND ECONOMIC LIFE}

same would be true if the annual income were equally divided. And these statements which hold true of the United States are even more true of the other nations of the world. Evidently before a satisfactory standard of living can be made available for the masses of men, production will have to be enormously increased. This hard scientific fact has an immense bearing upon economic problems and ideals. We see at once that the economic problem of the world is not merely one of sharing goods but of sharing responsibilities and burdens. This does not mean however that there should be any injustice in the distribution of either goods or burdens. Indeed it is obvious that one of the surest ways to increase production is for every one to have the conviction that his own individual efforts are certain to meet with just reward. Production is to be encouraged, but one way to encourage production is to equalize opportunities and to secure justice in distribution.

A fourth limitation which scientific knowledge places upon religious and ethical ideals is the fact that it is impossible for very large and complex groups to look after and safeguard completely the welfare and rights of their individual members through any collective measures. Hence the necessity of leaving to individuals a measure of liberty and of power to look after and safeguard their own welfare and rights. This is exactly what indeed the concept of private individual right connotes scientifically. It is a privilege or a power which society has seen fit to leave with the individual because social welfare on the

$\$ 354.00$, or $\$ 1770.00$ per family of five; and in 1918 , if reckoned in " 1913 dollars," it was still only $\$ 372.00$ per individual, or $\$ 1860.00$ per family of five. It is hardly necessary to argue that such an income per family would provide no high standard of living. See the works of King and Friday already cited. 
whole is promoted by the leaving of such right or power with the individual. Every social right, in other words, springs from a social function and presupposes a social obligation. ${ }^{1}$ But society functions through individuals. Hence every society finds it necessary to give some degree of security and liberty to the individual and to stimulate individual initiative and independence. The higher societies are especially characterized by this security and liberty of their individual members and by individual initiative and independence. This is, of course, one of the meanings of the institution of private property, and why it is necessary for a high civilization. It is evident that any scientific social program must aim at the furtherance, within all reasonable limits, of the security and liberty of the individual and at the promotion of individual initiative and independence of personality.

This clearly means that a scientific social program must aim at the extension of the benefits of private property to all, rather than the limitation of those benefits to a few. If private property aids in the reasonable security and liberty of the individual, then its benefits should obviously be extended to all. Now, it is precisely one of the just condemnations of our present economic system that it leaves so many without the protection and opportunities which a reasonable amount of private property would bring, while others have such large amounts that they are tempted, as we have seen, to prodigality, self-indulgence,

'Says Tawney (op. cit. p. 51): "The individual has no absolute rights; they are relative to the function which he performs in the community of which he is a member because, unless they are 80 limited, the consequences must be something in the nature of private war. All rights, in short, are conditional and derivative. They are derived from the end or purpose of the society in which they exist. They are conditional on being used to contribute to the attainment of that end." 
and even the grossest materialism. ${ }^{1}$ Obviously society should aim at the guaranteeing to each of its members, if possible, of the minimum amount of private property necessary to insure reasonable security and the development of personality. This it can do, we shall see, by a rational system of equalizing opportunities. Evidently, while the primary necessity of economic life is production, yet if the production of men be kept in mind as the great function of human society, then the just distribution of wealth and income in such a way as to promote the highest degree of common welfare is a problem scarcely less important than production itself. It is, of course, this problem of the just distribution of wealth and property with which our civilization is only now beginning seriously to grapple.

Now, these limitations which scientific knowledge places upon ethical and religious ideals in their relation to our economic life do not, of course, mean that a Christian social order or a co-operative commonwealth is impossible. To claim that a Christian social order is impossible because communism is impossible is absurd; and it is equally absurd to make the same claim because of the impossibility of the abolition of classes, or because of the primary necessity in the economic life of paying attention to production, or because of the impossibility of large groups safeguarding completely the rights and welfare of their individual members without private property and individual liberty. None of these limitations seriously affects the possibility of realizing a cooperative economic order in human society, because

${ }^{1}$ Compare Hobhouse's admirable presentation of the same general ideas in the chapter on "Economic Liberalism" in his Liberalism (Chapter VIII). 
co-operation is more dependent upon inner attitudes and ideals than upon external forms and machinery.

Nor do these limitations mean that the socialization of property is impossible, unless "socialization" is held to be synonymous with communism. But no sane social thinker holds to any such narrow conception of socialization. Socialization is the process by which individuals and things are made to serve the common welfare. Every individual and every institution, from the family to the state, should be socialized. This is indeed, in one sense, the whole purpose and end of the social process, and hence of social evolution. Property must become socialized, not less than the individual. All of the abuses of property spring from the fact that, like all existing institutions, it is still incompletely socialized, indeed, as we have noted, perhaps the most incompletely of all. But the socialization of property is not a matter which can be settled by vesting the legal title to it in a collectivity rather than in individuals. Legal ownership is a relatively unimportant matter as compared to the spirit which motivates the possessor of property in its use. Property, in a word, is to be socialized by socializing its use, by devoting it to the service of the common welfare. This is compatible with either private or public ownership.

Here we may note the absurdity of the idea, which is often put forth at the present time, that we are shut up to the alternatives either of endorsing the present economic system or of accepting some form of communistic socialism. Nothing so hinders the rational and ethical solution of our economic problems as the presentation of such a dilemma as the final word of social science. Nothing, too, could be more absurd than such a statement, because neither system has any adequate scientific support. The present economic system, as we have seen, represents 
a stage of economic life which in many respects more nearly corresponds to barbarism than to true civilization, while communistic socialism is an impossible system in any society with a complex industrial organization. Both modern capitalism, as it exists, and communistic socialism are highly unscientific. It would be nearer to the truth to say that social science indicates a hundred possibilities between these two extremes rather than to say that it endorses either.

What, then, are the changes which are needed to bring our economic system more nearly into line with the principles of social science? First of all, the principle upon which our economic life is based must be changed from one of rights and privileges to one of functions and obligations. Social functions and social obligations must become the supreme guiding principles in economic life as in other phases of social life. Social rights, as we have said, must be regarded not as primary, but as secondary to social functions and springing from the latter. "Men must regard themselves," says Professor Tawney, "not as the owners of rights, but as trustees for the discharge of functions and the instruments of social purpose." 1

In other words, the service of humanity must be made the end of the economic life. Society cannot be healthy in its business and industry until this principle is recognized. Upon it directly rests the great principle of reward which should control all business and industry, namely that remuneration should be based upon service rendered,-service not merely to one or a few but to society at large. This principle in its individual application is already generally recognized in our economic life. But individual selfishness has construed it to mean service

1 The Acquisitive Society, p. 51. 


\section{THE RECONSTRUCTION OF RELIGION}

to one or a few. In other words, a régime of individualism has permitted an individualistic definition of "service rendered" and hence its social perversion. Social utility and individual utility are not always convertible terms, economic analysis has shown; but it is social utility which determines social values; and hence individuals in their economic life must be willing, if they possess the social spirit, to let society determine what is a "service rendered" and what its just remuneration. This is undoubtedly the trend in our economic life at the present time, and we only need to hasten the process. Instead of permitting economic remuneration for catering to men's vices, for sharp practices or mere cunning shrewdness, for violence or fraud, it is evident that society should permit remuneration only for creative ${ }^{1}$ labor and for saving; and that individuals with a socialized conscience should seek wealth only through creative labor and through saving.

Until we have a society, however, made up of individuals seeking to gain wealth only through creative labor or through saving, rather than seeking to attain it through chance or privilege or the opportunity to drive a bargain, wo shall fail to secure an economic life which is just or in harmony with scientific principles. Society, to be sure, should do everything possible to make it difficult for men to secure economic rewards through chance or privilege or opportunities to drive hard bargains, but even more it should do everything possible to encourage creative, or productive, labor and to reward it. If it follows out far enough the principle of rewarding creative labor, it will automatically discourage attempts to secure money through sharp practices. The entire

1 "Creative" is here used in the sense of "productive." Routine labor in this sense is creative, since it is productive of social values. 
order of society should be such as to encourage creative labor by all who are able to work. Especially should social religion find in creative labor the primary and most elemental form of human service and honor it as such. Its social dignity, whether it be of a material or of a spiritual nature, must be constantly affirmed, and idleness in every social class condemned.

Saving, too, is a service rendered to society, of a conservative rather than a creative sort, and, in spite of all ideas to the contrary, equally entitled to economic reward, though the reward to creative labor in a society which hopes to be progressive must be kept proportionately larger. All human progress, however, rests upon the accumulation of economic goods as well as upon the accumulation of knowledge and good will. All waste in human society is a waste of life, while all saving and conserving makes possible the further upbuilding of life. The ethical legitimacy of interest, considered as a social reward for personal saving, can be questioned only by those who fail to appreciate the positive function of saring as a form of social service in economic life. This does not justify, of course, the living off of interest received from the savings of others, ${ }^{1}$ which we so frequently find in modern society. That is a more complex question which we will touch upon later, when we consider the use of "findings" in society. It is sufficient at present to point out that in a right-minded society, individuals will seek their economic income chiefly in two ways: first, through creative, or productive, labor; and secondly,

1 Nor what Professor Small calls the "absentee types of income" so frequently associated with modern capitalism (i.e., the receipt of income from capital with no business responsibility or service on the part of the owner of the capital). 
through interest received from personal savings invested in private business or in public enterprise.

Equally important with these principles of distribution, is the spirit of co-operation in service in our economic life. If all business and industry are for the sake of the service of the common welfare, then employer and employee are co-partners in that service. Labor should not be regarded as a "commodity" any more than the directing ability of the employer should be so regarded. It would be truer to the facts to regard both as co-partners or collaborators in the common task of production. Both co-operate in a common service, and the service is not rendered simply or even chiefly to each other, but rather to society at large. If the spirit of co-operation for the service of the common weal could dominate our business and industry, conflicts of employer and employee would be minimized and, with the more scientific organization of industry upon a basis of social justice to all parties, might, in time, entirely disappear. ${ }^{1}$

\section{So much for the general ethical principles which}

1 Among the many employers throughout the world who are putting such principles to practical and successful test, no one is perhaps more conspicuously successful than Mr. B. Seebohm Rowntree, British Quaker manufacturer and well-known student of industrial conditions. Mr. Rowntree lays down three fundamental principles which should control in the relation of employer and employee:

(1) "Industry must create and develop fellowship. Any practices calculated to destroy such fellowship are immoral."

(2) "Every individual is of intrinsic worth, and human labor cannot be considered a commodity."

(3) "Industry must consider among its first charges the provision of an income sufficient to maintain in reasonable comfort all who engage in it; provision for special burdens to which those who engage in it may be subjected; provision for superannuation; provision for health conditions, development of personality, talents, and selfexpression."

See his book, The Human Factor in Business. 
should guide in our economic life. Many would hold that social religion cannot go further than to lay down such general principles. But surely, social knowledge is far enough advanced to indicate also some concrete practical steps toward the realization of these principles. In the first place, it is evident that if we wish the co-operative spirit to dominate in our economic life, we should do all we can to encourage private co-operative enterprise. The end of free society is surely in learning the principles of social co-operation, and voluntary co-operation must be the first step. By such cooperation in private business and industry a people may learn how to undertake and carry through public enterprises in a co-operative way. Voluntary co-operation in private enterprises is, to some extent, probably necessary education for the successful conduct of co-operative public enterprises. Public ownership should be looked forward to as the normal development of the co-operative spirit in all communities, at least in lines of business and industry which are suited for public ownership.

Just at present, economists seem rather agreed that public ownership is apt to be successful only in those industries which have been reduced more or less to routine, which require little initiative, or which for public reasons may be more conveniently conducted by public than by private agencies. But the range of industries which may be successfully carried on through public co-operative enterprise may obviously increase with the increasing intelligence and good will of the whole society. Moreover, through the progress of science, many businesses and industries may in time be reduced to routine, which now apparently require great individual initiative and the pioneering of exceptional ability. It would be a rash man, therefore, who would place limits upon public 
ownership and public co-operative enterprise. Our general social principle of maximizing co-operation in society would seem obviously to imply the maximization of cooperative public enterprise also. The safe principle in our present stage of social and economic development would seem to be to retain both private and public ownership according to the needs and convenience of society at large, hedging private ownership about, however, with such safeguards and regulations as will gradually educate and train the whole mass of the people to carry on their economic life co-operatively through public organizations.

Such education for the successful undertaking of cooperative public enterprises will automatically result if a larger measure of democracy is introduced into the present organization of industry. Democracy in industry is a step toward public co-operative enterprise, and is indeed the only basis upon which public ownership and management would be tolerable. Now democracy in industry, as in the social life generally, means fraternity, good will, and the equality and freedom which are necessary to realize fraternity. It is in line with that principle of co-partnership which we spoke of above. But concretely, it means that employees have some voice in the conduct of the business and some control over the conditions under which they work. It means that a given industrial group is not ruled autocratically, but by the opinion and will of the whole group. Various concrete methods have been devised to bring this about, such as shop committees, industrial councils and the like; but the obviously important thing is the spirit of democracy and fraternity in both employer and employees.

By concrete measures which will encourage private co- 
operative enterprise, public ownership and management where practicable, and the more democratic organization of business and industry, modern society can enter upon a deliberate policy of maximizing co-operation in its economic life. If it is going to minimize hostility and conflict, however, it must enter also upon a general policy of equalizing opportunity for all. For the equalizing of opportunity is of the very essence of a democratic, Christian organization of the economic life. It should be possible for every child born in a rightly organized society to have equal opportunity with every other child of developing the best that is in him and of demonstrating his real social worth. Such equality of opportunity is obviously difficult to achieve in practice, but it must be unweariedly striven for by a society which aims at social justice, and it is the mark which distinguishes a liberal, democratic organization of society from the various Utopias based upon some kind of benevolent autocracy. Yet to keep equality of opportunity in the economic life has been found to be next to impossible under our present laws for the acquisition and inheritance of property. Those laws must certainly be modified if we wish to achieve equality of opportunity and to preserve it.

But before we speak of necessary modifications in present laws and institutions, let us guard ourselves against the error of thinking that equality of opportunity means the establishment of dead-level equality in society. On the contrary, equality of opportunity implies the possibility of inequalities developing between individuals, and especially in regard to economic reward. What equality of opportunity does is to give every one a fair chance and allow individual ability and merit to manifest themselves without any hampering artificial conditions. Equality of 


\section{THE RECONSTRUCTION OF RELIGION}

opporturity will throw the individual more on his own resources and not permit special privilege to make success for some and to deny it to others. It is therefore a further step in the rational development of individual responsibility and of personality. But from equality of opportunity we must expect that inequalities will develop; for different individuals with different abilities will make different use of their opportunities and achieve results of very unequal social value. But these inequalities will be the result, not of artificial social conditions, but of the different uses which individuals voluntarily make of their equal opportunities. The passion for equality, then, should not be confused with the passion for justice in social and economic life. If we are just we shall wish different degrees of social merit to be differently rewarded. We shall wish, not equality of reward, but equality of opportunity.

What concrete measures in addition to the development of co-operation and democracy in industry will work toward the equalizing of opportunities in our social and economic life? Obviously, the measures which have been devised by scientific social workers to minimize the inequalities which result from ignorance, sickness, unemployment, low wages, hereditary physical defects, accident, old age, and death. All of these matters are more or less subject to social control. For example, so many inequalities of opportunity spring from our educational system that if we want equality of opportunity, obviously we must devise an educational system which will give every child an equal chance in education, regardless of the economic status of its parents or guardians. Concretely, it should be as easily possible for the poor child of ability to get even the highest university training as for the child 
born in the most fortunate economic surroundings. Education should be made available in proportion to abilities shown by students rather than in proportion to the wealth of parents or guardians.

Again, if we wish equality of opportunity, conditions of public health must be equalized. The health of the poorest child should be protected not less than the health of the child born in the richest family, and the conditions and hours of labor of the poorest class of workers should be kept strictly in harmony with the laws of their physical well-being. The wage worker must also be protected against unemployment and its dangers. The surplus profits of periods of prosperity should be made available, through systems of saving and insurance, to tide the worker over periods of industrial depression. The same thing should be done to meet the crises in wage-earning families occasioned by sickness, accident, old-age, and death. In general, industry should furnish the worker adequate protection in every precarious situation; it should be made safe for the worker and derelop rather than lessen his manhood. Therefore, wages below the standard necessary for a decent living for the worker and his immediate family should not be tolerated. Indeed, every community should maintain a minimum standard of welfare for all its citizens beneath which it should suffer none to fall as long as its total resources are adequate to meet the need. ${ }^{1}$ All of these measures are within the

"This is the "first pillar" in the justly celebrated "Report on Reconstruction" of the British Labor Party. (See The New Republic, February 16, 1918, or Ward, The Nevo Social Order, Chapter VII.) The other three "pillars" of the new social order were:

(2) The Democratic Control of Industry.

(3) A Revolution in National Finance, that is, the system of taxation. Good.

(4) Use of the Surplus Wealth of the Nation for the Common 
limits of the economically possible and should receive the support of humanitarian religion.

If the principles and measures which have just been set forth could become incorporated in our economic life and system of industry, while perfect equality of oppor-, tunity might not be realized, it would be approached. Certainly the glaring inequalities of our present social order- "vast wealth for the few and insufficiency for the many; luxuries for the rich with miserable hovels and insufficient food often for the poor; idleness for the few and excessive hours of toil for the many;-frequent subordination of the well-being of the many to the financial profits of a few"-all these things would disappear. Industrial poverty-poverty resulting from economic conditions rather than from weakness in individual character -would be gradually abolished and prosperity diffused among all classes. It is no exaggeration to say, as Professor Carver says, that "we need not have poverty in our midst a generation longer than we want it," ${ }^{1}$ provided, of course, we are willing to bear the cost of the scientific measures necessary for its abolition.

Even the staggering costs of the great war have probably not made it impossible to extend economic justice and prosperity thus to all classes if we will take thought and develop the right social attitudes. Unless humanity's resources are crippled by further wars and class conflicts, probably the most advanced nations of Europe and America could abolish poverty within a generation or so. For ours is still a dynamic, expanding economic life which is not yet near the limits of its resources. There is still an economic surplus accruing to many through the discovery and development of new material resources and

${ }^{1}$ Principles of Political Economy, p. 583. 
of latent capacities in men, as well as through the increase of our numbers and the multiplication of world contacts. Hence to many in such a society come economic gains which are not the result of their creative labor or of their saving, but which have been made for them by the circumstances of social and economic development. Thus enormous fortunes accrue to a few individuals, who are happily circumstanced and have business shrewdness, from what economists call natural monopolies, from the rise of land values through the increase of population, and from unexpected social emergencies. These "findings," as we may call them, which come from a combination of circumstances and business shrewdness, are greatly increased through our laws of inheritance which permit the passing along of this property almost intact from generation to generation. Such inheritance of property from a previous generation is, of course, a "finding" for the generation that receives it. Evidently no ethical social question could be of more practical import at the present time than the question what attitude individuals and society should take toward such "findings"-that is, toward wealth which has come to individuals as a result neither of creative labor nor of personal savings.

On the side of the individual, it would seem that if the principle be accepted at all that property should be held as a trust from society, then the individual should feel that this principle holds doubly in the case of wealth which comes into his hands as the result neither of his personal labor nor of his personal saving. He should recognize that such income is a result of no effort of his own and belongs in a peculiar sense to society, from which he receives it in trust for the common welfare. On the side of society, it would seem that, while it may be generally convenient to leave a large part of these "findings" in 


\section{THE RECONSTRUCTION OF RELIGION}

the hands of private individuals, yet obviously when social emergencies exist, this unearned wealth should be the first to be drawn upon through taxation to meet social necessities. "Taxes," says Professor Shenton, "are a contribution which an individual or a corporation makes for the public good." 1 Now, while taxes should be levied to some extent upon personal earnings and savings, because all should contribute to the public good, yet obviously they should be levied according to the ability of individuals to contribute, and hence should be levied much more heavily upon "findings" than upon "earnings," as the recipients of the former are usually much more able to make contributions to the public good. This, as a matter of fact, is the policy at the present time of all the more advanced nations of the world.

Hence, if it be asked where society will get the funds necessary to carry out the program for general social amelioration and the equalizing of opportunity which we have sketched, the answer is that such funds should be drawn in the main from the economic "findings" which happen to drop into the hands of individuals, or in plain terms, from taxes upon inheritances, upon all monopolies of natural resources including monopoly land values, and upon excessive incomes whether derived from interest or speculative profits. ${ }^{2}$ The proper adjustment of such taxes so as to promote general social well-being is a matter for experts to decide, but that they can be so adjusted all experts in taxation agree. The chief point for us to note is that in these three great sources of public revenue, through taxation upon "findings," there are ample funds to carry out within one generation or two any reasonable

${ }^{2}$ Christian Aspects of Economic Reconstruction, p. 23.

2 For elaboration of the importance of taxation as a means of social reconstruction, see The Social Problem, Chapter IV. 
program for the betterment of the social and economic condition of the masses, provided of course that such funds are not squandered by corrupt governments, by unscientific attempts at social amelioration, or by foolish conflicts between classes, nations, or races. Such a program is easily within the limits of the socially practicable and has, as a matter of fact, been entered upon by the. most advanced communities in the modern world. Thus through scientific taxation, wealth and opportunity might become far more justly distributed in our society, and as we have already said, if supplemented by other scientific measures, poverty might be wiped out within one generation or two.

However, before any such utilization of the economic surplus of society for the common welfare could become general the whole attitude of the possessing classes toward wealth and toward their fellow human beings must be changed. There lies the fundamental difficulty. As long as economic possessions are valued more highly than human lives, so long it will be impossible to put on a program of social and economic justice in society at large. What is needed, and what social religion should undertake to get recognized, is a socialized ethics of the expenditure and use of wealth. We have already spoken of the ethics of acquiring wealth. Equally important is the ethics of spending wealth.

The first legitimate use of wealth is, of course, that of self-maintenance and the maintenance of one's immediate family, because self-support is after all the first economic service which any one is called upon to render to society. The second legitimate use of wealth should be to contribute to the common welfare, especially through submitting to taxation to meet public needs. The third 


\section{THE RECONSTRUCTION OF RELIGION}

legitimate use of wealth should be to use it for the development of private business, that is, of private productive enterprises which will increase the prosperity of the whole community. The fourth legitimate use of wealth is for private gifts and benevolences to help others, and especially to promote worthy causes which work for the public good, such as private philanthropy, private educational enterprises, and above all, religious and moral movements. If there is any legitimate place in the use of wealth for private luxury and self-indulgence in a socialized scheme of ethics, it must come fifth and last. But it is exactly to this last use that a very considerable portion of the surplus wealth of most modern nations, and especially of the United States, is devoted according to the most careful calculations. ${ }^{1}$

If it were not for the waste of wealth in luxury and in self-indulgence, a sin of practically all social classes, we should have ample funds not only for religion and education, art and science, but for wiping out poverty and all the gross inequalities which exist in modern society within a comparatively short time. Hence the fundamental need of our society, after all, is more socialized standards of economic consumption, or, in other words, of the expenditure of money. Yet few would disagree that some such order of expenditure as that just outlined, should be observed. Indeed, it is practically the order enforced by law when social emergencies occur. Selfmaintenance comes first, but luxury and self-indulgence

${ }^{1}$ According to government returns given out by the Federal Bureau of Education, the people of the United States spent for luxuries in $1920, \$ 22,700,000,000$, or more than one-third their total income. For tobacco alone, nearly as much was spent as for edueation and religion combined, and its total cost in one year was more than all that has been paid out by the people of the United States for higher education in 273 years. See School Life for April 1, 1921. 
come last in every code for the expenditure of wealth which society can afford to recognize. Hence again, it is evident that social obligation in the use of wealth is the fundamental principle which must be recognized in any attempt to transform our economic system.

We have sketched no impossible Utopia but only the goal towards which the best economic thinking in our civilization is moving. Practically all such thinking agrees that we need an economic system which will put human values first, which will emphasize economic obligations rather than economic rights, which will maximize co-operation both along private and along public lines, which will equalize opportunity, and finally which will make private wealth a trust held for public good. Yet these conclusions of our best social and economic thinking, after all, are not different in essence from the principles laid down by Jesus in his dealing with economic questions. He did not speak of rights, but of obligations. $\mathrm{He}$ had regard only to the human values. He emphasized that the first use of possessions, after self-maintenance, if not equally with it, was to help others and to promote all worthy causes. Finally, we may say that his whole thought of wealth centered on the idea that it was a trust for which the individual was to be held strictly accountable to God and administer for the benefit of his fellowmen. ${ }^{1}$ These may be very simple and elementary principles, but our civilization has evidently not yet been able to realize them in its economic life; or rather it has not seriously tried to realize them. Yet modern science, we see, has come to practically the same conclusions. It

1 The reader cannot do better than consult for the elaboration and application of Christian principles in industry, the report of the Committee on the War and the Religious Outlook on The Church and Industrial Reconstruction, published in 1920. 


\section{THE RECONSTRUCTION OF RELIGION}

might be well, then, if the modern world would emphasize the economic aspect of the religion which it professes. It is at least safe to say that no economic disaster will come to our world through following out the ethical economic principles taught by Jesus. Some of the possessing classes apparently fear these principles, because they see that the result of their application, even though it may mean the extending of justice and prosperity to all, will be the diminution of their own wealth and privileges. On the other hand, social disaster will inevitably come if we much longer attempt to conduct our business and industry upon the pagan principles which have been so much in vogue in our economic life. Here again, then, the findings of social religion and of social science are practically the same; hence there is no longer excuse if these two fail to work together for the redemption of our economic life. 


\title{
CHAPTER IX
}

\author{
RELIGION AND POLITICAL LIFE
}

A RELigion adapted to the needs of modern life must have a positive and unequivocal doctrine concerning those relations of men to one another within nations, and of nations to one another which we term "political." Social religion must fearlessly oppose the pagan idea of the state and all forms of political immoralism, because if organized authority in society does not recognize itself as bound by moral principles, we can scarcely expect that individuals will do so. If the very principle of organization in society is itself immoral, such as the principles of force and expediency, it is idle to think that the conduct of individuals will, as a rule, rise to any higher level.

Social organization and social control are two of the most pervasive influences in the lives of men, and their chief expression is in political life and institutions. Group organization is the chief means by which the individual functions in social life, and group control is the chief social means of determining individual character. Now, above all lesser groups, next to humanity itself, stands the political state or nation. In our present world, indeed, it is the highest controlling group. If immoral principles are tolerated in the form of its organization and control, then a Christian social order is impossible. Religion has vast issues at stake in political questions, as indeed the Great War made evident. It should be one of its first tasks to secure among men such political or- 
ganization as will make possible a normal life characterized by good will and co-operation, peace and security.

Yet notoriously the political, like the economic life, has remained divorced from religion and, even in the most Christian nations, relatively pagan down to the present time. Over a generation ago, the late Professor Lester F. Ward said, "In politics, we are still in the Stone Age," and his statement seems almost as true to-day as when it was uttered. From Machiavelli's time to the present, as we have seen, ${ }^{1}$ we have had our political life controlled largely by the pagan principle that the end of the state, and even of political action within the state, is power. By the single end of gaining or holding power, whole nations, as well as political parties within nations, have sought to justify their conduct. Fear and force are still the main reliances of the state in international relations, and often even in internal government. Thus the pagan state survives in our world, not merely as an idea, but as a fact. It is, indeed, perhaps the most challenging fact, next after our pagan industrial system, which confronts social religion to-day.

Even when Machiavellian principles are not openly avowed in politics, political conduct is frequently divorced entirely from religion. It is said that the political belongs to the secular and should not be under the control of the religious. There results the politics of selfinterest, which while it may not be as starkly pagan as Machiavellian politics, yet works to the same end. Individuals in such a system act politically according to their self-interest, or according to individual expediency. Selfinterest, however, usually coincides with some class interest, and so politics becomes a struggle of classes for

${ }^{1}$ See Chapter IV. 
power. Under such circumstances, politics and government become an expression of contending selfish interests and men lose faith in government and law, because they seem to represent only the triumph of the selfishness of one class over the selfishness of another class. Thus respect for all law and government is undermined.

Still more disastrous results are seen in the relations between nations. If moral principles are not binding in those relations, then, as so many German publicists said before the Great War, there can only be etiquette, but no morality, between nations. Consequently, it is impossible for a state to transgress the moral law in its relations with other states. War and conquest are thus justified and become inseparable from international relations. It seems incredible that such monstrous doctrines could be sanctioned by civilized peoples; yet we know that until very lately they were openly sanctioned. Even when not openly sanctioned, they were often secretly acted upon. However, the doctrine that the chief end of international politics is commercial success is morally no higher, and it has had very similar results. For this end the exploitation of smaller and weaker nations has been brought about by various forms of intimidation or intrigue which have been called "diplomacy." Such standards have been so prevalent in the past that our whole political life, national and international, has been essentially pagan and well calculated to increase suspicion, hostility, and conflict among classes and nations. This, as we have already seen, was the profound cause of that great convulsion which shook our world from 1914 to 1918, and which has left European civilization shattered and uncertain.

Evidently we have been trying to live under an unsound political system, a system which is far from mini- 
mizing hostility and conflict among classes and nations. Manifestly we need a system which will maximize cooperation among the nations as well as between classes within the nations. We need a political life built upon a different principle than power as the end, and which shall use different methods than fear and force. Good will should replace fear, and understanding should take the place of force. But this cannot be as long as group selfishness dominates political life. If we are to maximize co-operation between nations and classes, the whole spirit of our political life must be changed. Instead of a politics of power or of self-interest, we must have a politics of service. In other words, we need a politics which will recognize the service of humanity as its end. This end must be sought, of course, through the highest and best development of each individual nation, and even of all the classes within each nation. Such politics is not inconsistent with the highest patriotism, because loyalty to humanity does not weaken loyalty to country, when the end of national existence itself becomes the service of humanity. Patriotism and humanitarian religion may in time thus blend and become practically indistinguishable, though at present they may so often seem to be in contradiction to one another. A true nationalism and a true internationalism are not opposed.

What sort of political organization will further best the co-operation of nations and classes and work for the highest and best development of all individuals, classes, and nations? Such an organization manifestly would have to appeal to the hopes and stimulate the aspirations of all men. It would have to recognize the full rights of the common man as a member of society. It could recognize no artificial distinctions of caste or class, of race 
or blood, but would have to recognize the potentially equal social worth of each man, and assign to each his position in accordance with his personal merits. It would have to aim at substantial equality of rights and opportunities for all classes of men. Such a political system would aim at the welfare of all and not of any special class or group. Its ultimate aim, indeed, could be nothing less than an adequate life for all.

Yet such a political system, if it is practicable, could not be imposed upon society from above or without. It would have to grow up from within, from the will of every member of the political group. Superimposed benevolence cannot reconcile men to one another nor develop the highest and best within them. That is possible only through mutual understanding, the free exchange of ideas and ideals, and the free formation of a common or group will. Hence a political system which aims at the welfare of all must give the will of every adult, intelligent person a share in the making of the common will of the group. This means that the group becomes self-governing, selfdetermining, and not only the group, but every individual. Men must be free, as well as equal in right, in such a political organization. And this sort of political organization is called a "democracy."

Such a social and political system is the only remedy for those class divisions, distrusts, and misunderstandings which threaten to tear our civilization asunder. It alone can reconcile men to one another, because it recognizes the worth of each man, counts each as one, and enlists the interest and will of each for the good of the whole. It alone, through the free exchange of ideas, the interpenetration of mind and mind, the free formation of a common opinion and will, brings understanding and sympathy between classes and puts their co-operation upon 
a voluntary basis. ${ }^{1}$ It alone is capable, therefore, of warding off class strife and preventing revolutions of violence. Finally, it alone can reconcile the nations, be cause it postulates equality of right between nations and seeks co-operation through understanding and good will.

Such democracy is not an idle dream, though it be a dream which the peoples of Western civilization have been dreaming already for a century. With its emphasis upon fraternity, and upon the equality and liberty which are necessary for fraternity, democracy is evidently the same movement in the social and political realm as Christianity in the ethical and religious realm. ${ }^{2}$ The religion of Jesus, as we have seen, is essentially an attempt to take the sentiments, affections, and values which are naturally characteristic of the family and universalize them, making them the standard of social practice for all men in all their relations with one another; while democracy is an attempt to carry over from the family and the neighborhood the "patterns" of fraternity, equality, and liberty, furnished by these primary groups, to the wider social and political life. Hence, the demncratic movement has the same social and psychological roots as social religion. The two movements have many things in common. Their ideals are essentially similar and derived from the same source. $^{3}$

1 Among the many writers who have set forth these ideas, Hobhouse (Liberalism); Mecklin (An Introduction to Social Ethics); and Miss Follett (The New State) especially deserve mention. Professor Mecklin's book, in particular, discusses democracy as "the solution of the social problem," showing how essential democracy harmonizes social relations in the family, the church, the school, and the factory, as well as in the state. Miss Follett's book is an acute sociopsychological analysis of the democratic social process, showing how it involves the interpenetration of minds and the creation of a group mind.

See Cooley, Social Organization, Chapter V.

- Compare Chapter III. 
Now, as we noted in the very first chapter of this book, one of the reasons for the failure of existing religion is its failure to become adjusted to democracy. We should expect a close alliance between religion and democracy in modern society. To a considerable extent this is what we find. Nevertheless, the cases of maladjustment between them are almost as striking as those between religion and modern science. ${ }^{1}$ Conventional religion, of course, approves of democratic forms of government so far as they have been developed in countries where they are already established. Yet the conventional Christianity of church members too often seems to fear the program of democracy when it comes to the relations of classes, nations, and races. Existing religion, too frequently, has no vision of -democracy in these relations. It tolerates great gulfs between economic classes, between nations, and between races. It may be very strenuous, as it is in some denominations, regarding a democratic organization within the church; but it may be very indifferent toward the rights of the common man and toward the great question of substantial equality of rights and opportunities in society for all men.

Yet it should be evident that the democratic movement in the modern world is as much the natural ally of social religion as is social science. Modern democracy is essentially a movement to realize the ideals of social religion; and all genuine social religion is necessarily a religion of democracy. If religion is sufficiently developed on the social side, it will furnish the dynamic which will make possible the realization of democracy. It will foster the sympathy, understanding, and good will between indi-

1 A brief statement of these maladjustments was made by the writer in a paper read before the American Sociological Society in 1919 on Religion and Democracy (Vol. XIV of the Proceedings). 
viduals, classes, nations, and races, which are necessary for the working of democracy. It will not fear to put on a program of justice and fraternity between races, nations, classes, and in social life generally.

On the other hand, the democratic movement should find its natural ally in social religion; for democracy presupposes social religion and is unrealizable without it. Inasmuch as the democratic spirit is unwilling to recognize the artificial distinctions of class, race, or other external conditions, it is plain that it pre-supposes, as an ethical axiom, that all men are brothers and are equal in rights. Thus democracy, in the modern sense of the word, is an achievement of humanitarian civilization and its fate is bound up with the progress of humanitarian religion and ethics. Or rather, must we not go still further and say that democracy is an aspiration, a social and political ideal, which is unrealizable except as we develop a Christian world? True democracy was born from social religion, especially from the religion of Jesus, and its fate is bound up with that of social religion. "The democratic movement," says Professor Cooley, "in so far as it feels a common spirit in all men, is of the same nature as Christianity." For its harmonious working, even when imperfectly developed, democracy requires more good will, more social intelligence and character in the individual, than any other form of government or society. It requires, therefore, that social values be brought to the individual in the intensest way. That is, it requires the help of social religion. An irreligious, atheistic, materialistic democracy might be possible for a time, but in our complex society, it could have no chance of success in the long run.

${ }^{1}$ Social Organization, p. 203. 
If the substantial identity of the ideals of democracy and humanitarian ethics be conceded, then it is evident that democracy will be realized in proportion as the ideals of social religion are realized. Both are not only practicable, but indispensable for our civilization. The control of social life by custom or by coercive authority is no longer practicable in a dynamic civilization like ours. Though custom-ruled and authoritarian societies, sometimes mistakenly called "democracies," have characterized the history of the world from the earliest times down to the present, yet this does not show that they are adapted to present needs. Our world is entering upon a new stage of social evolution as we have tried to show, a stage of awakened social consciousness, of higher social and ethical ideals, of true civilization; and the aspiration for democracy, for a new and freer form of social control, is coincident with this new stage of social evolution. The peoples of the world are dissatisfied with the old authoritarian forms of social life, and are groping toward a new and higher form of society.

Authoritarian control sprang originally from the conquest of one group by another, and so is unsuited to a world that is trying to rid itself of the ethics of barbarism. Hence, surviving autocracy in the forms of government, of industry, and of social life generally occasions much of the unrest of the present. Authoritarian control is an anachronism in the modern world. Human society must find a new basis for its own control. That new basis is in the rational like-mindedness, the intelligent purpose and will of its individual members. It must seek its unity not through coercive authority, but through the sympathetic understanding and intelligent purpose of the whole population. The untrammeled opinion and will of every adult member of society must be given a share in 


\section{THE RECONSTRUCTION OF RELIGION}

the determination of social policies and institutional forms. This is the new, experimental phase of social life upon which we have already entered. We cannot turn back. We must go on to perfect a democratic social and. political life, or we must fail altogether.

We should not wish to turn back; for democracy is bound up with the attainment of all our higher personal and social ideals. A self-conscious, self-determining civilization is necessarily democratic; for the essence of democracy sociologically, as a form of social control, is that it is an attempt to do for the group what organic evolution has already done for the individual: to let it be ruled freely by its own mind. Just as in the developed individual, the mind directs and controls, so in a democratic group or society, the social or public mind-that synthesis of all the individual minds active in the group -directs and controls group behavior. We say that democracy is "the rule of public opinion." And this is correct; but public opinion is nothing but the synthesis of individual judgments. Again, we say that democracy is "the rule of the popular will"; but the popular will is nothing but the co-ordination and co-operation of the active wills of the individual members of the group. A society is democratic just in the proportion that the opinion and will of every individual in the group is free to count in the determination of group policies and conduct. Democracy, therefore, means the development of personality as well as of social life.

However, just as we begin to perceive the outlines of that free and self-determining society at which modern civilization is aiming, and which we hare agreed to call "democracy," we begin also to see its difficulties and dangers. While autocratic forms of social organization and 
control will no longer work in our world, yet the democratic forms are so untried and so dependent upon the development of personality in individuals that their success is still a matter of uncertainty. If they are to succeed, democratic societies must attain to a new level of development of intelligence and character in the mass of their individual members. Obviously, democratic control may be ignorant and brutal, if public opinion is uninformed, irrational, or biased by selfish interests. For public opinion, let us remember, is simply the result of the co-ordination of individual opinions. If individuals remain ignorant and selfish, the group opinion and the group will cannot be otherwise, and social disaster must follow. There is no magic in numbers; neither can we safely trust "the goodness of human nature." If democracy is not to result in disaster, it will be only because it becomes a conscious achievement built upon the adequate development of personality in the mass of individuals. Democracy is an adventure for our world because the intelligence and character in individuals necessary for its success still remain to be developed.

That the future of democracy, then, depends absolutely upon the social and political education of the masses of the people is obvious; for vast masses of men cannot form rational opinions and execute rational social decisions without highly developed social and political intelligence and character in each individual. Democratic societies thus need to educate every individual for his share in the work of social control, at least to the extent of enabling him to decide wisely and unselfishly between competing policies and leaders. To a greater and greater extent, no doubt, this social and political education may be imparted in the public schools. But there is danger here, since stereotyped and ready-made judgments on social and po- 


\section{THE RECONSTRUCTION OF RELIGION}

litical questions can never be adequate for intelligent social control in a dynamic civilization. The intelligence and education which democracy demands must be a progressive affair. The whole people must be continually informing and educating one another regarding the social conditions and needs of every portion of the population. Consequently democracy depends upon freedom of intercommunication among individuals, upon free public discussion, a free press, free assemblage, and the free selection of public policies and leaders, not less than upon good social character in individuals. All of these means of public education of the masses in social and political matters must be kept alive in a democracy; for the interpenetration of mind by mind is the very method of forming public opinion and popular will. Moreover, if public opinion is to become highly rational, freedom of thought as well as freedom of intercommunication must be encouraged. The dependence of democracy upon these agencies,-schools and education, free speech and a free press,- has for these reasons become a commonplace. Yet all of these things, if they are to work without perversion, manifestly imply a highly socialized character in individuals. They imply participation in the higher social values by the mass of individuals. Social religion should be vitally interested in them; and can be of vital help to them.

The greatest foe of democracy, next after social and political ignorance, is the unsocial spirit, whether it manifest itself as the selfishness of individuals or of groups. Indeed, democracy in the modern sense, depends upon social sympathy and good will quite as much as upon social intelligence. For this is what we mean largely by a socialized character in individuals. It is, at this point, 
too, that the absolute dependence of modern democracy upon social religion emerges; for in the great civilized nations of the present, the good will which is merely the spontaneous expression of natural impulse, as it was in the primitive kinship group, will not suffice. The good will which modern democracy must draw upon must be an ideal creation. It must spring from that understanding and sympathy which comes from the deliberate culture of altruistic and fraternal sentiments in heterogeneous populations. This "fraternalism" in modern democracies must take the place which the sentiment of kinship held in primitive groups as the foundation of sympathetic like-mindedness and unity. Things which destroy sympathy, understanding and good will in populations are not less menacing to democracy than things which destroy free thought, free speech, and the untrammeled expression of public opinion. The growth of barriers, therefore, that obstruct sympathy and understanding among different elements of a nation will, in the long run, be just as fatal to its democracy as the growth of institutions limiting the free interchange of ideas and the free expression of popular will. Hence democracies need the help of social religion, especially, for the cultivation of a fraternal spirit among their members.

Individual selfishness becomes particularly menacing to democracy when it assumes the form of exaggerated individualism. In America, in particular, the conception of democracy has been too frequently that everybody should be allowed to do as he pleases, provided that he does not interfere with the rights of other individuals. Such an individualistic, laissez-faire democracy rapidly destroys the sense of social obligation, leads to the overlooking of the solidarity of the interests of communities, encourages lawlessness, and tends eventually toward 


\section{THE RECONSTRUCTION OF RELIGION}

anarchy. Even when it does not go so far, such individualism hinders social organization and social efficiency, and so discredits democracy. To combat such a danger, democracy obviously needs the help of social religion. It must temper the liberty which it preaches by a religion of social obligation and of social solidarity.

Group selfishness is another great foe of democracy. Just at the present time, it is perhaps the most immediately threatening enemy of democratic institutions. There can, at least, be no doubt as to its danger to democracy; for nothing destroys social sympathy and good will so quickly as group egoism and group conflicts. Even political partisanship which goes to the extent of destroying sympathy and hindering co-operation is destructive of democracy. A high degree of social tolerance is necessary for democracy to work at all, and a cordial co-operative spirit for its satisfactory working. In a true democracy, accordingly, minorities and majorities, whether they be political parties or economic classes, must retain a tolerant, if not a fraternal attitude. Hence in a democracy, there must be no absolute rule even by the political majority. The rights of minorities must always be respected, even the rights of the single "conscientious objector"; for democracy pre-supposes that a minority, or even a single individual, has a right to convert the whole group to his way of thinking, if he can. Otherwise, it denies its principle. True democracies, consequently, are never strong-handed or tyrannical in their methods. As soon as they become so, they convert themselves into autocracies, because they shut out some classes or individuals from participating in the formation of public opinion and of popular will. This does not mean that democracies have to tolerate positive wrong-doing any more than any other 
form of society. It is only saying that by their very principles, democracies are tolerant toward differences of interest or of opinion among their members, and seek a synthesis of these differences through appeal to the higher interests of the community.

How, then, can democracy combat group egoism and put an end to the selfish aggression of parties and classes? Only through the cultivation of tolerance, sympathy, and understanding between all the parties and classes which make up modern complex communities. The cultivation of social intelligence through enlightenment regarding social conditions will help much. But before a socially efficient imagination can bridge the misunderstandings and differences of interest which exist among the parties and classes in complex societies, there must be systematic cultivation of social sympathy and good will. Idealistic social ethics and religion must come in as the ally of social information if we wish unfailing fraternity and good will in a large population with many diverse interests. The selfishness of individuals and of groups must be subordinated to devotion to the common welfare, and such an idealistic devotion must for the mass of men rest upon an essentially religious basis.

All this becomes clear enough when we see class aggression and class conflict actually destroying the unity of democratic societies. Then we perceive that it is lack of sympathy and understanding which leads one group to try to impose its will upon another. Such lack of sympathy and understanding may, of course, spring in part from mere ignorance and illustrate that need of knowledge of social conditions which we have spoken of as indispensable for the working of democratic institutions. But it is also frequently the result of a selfish attitude of one group toward another, and illustrates the lack of social 


\section{THE RECONSTRUCTION OF RELIGION}

good will in society. A dominant group, for example, which possesses power and privileges not infrequently refuses to give up any part of these to meet the needs of other groups. Here, clearly, it is the non-fraternal attitude of one group toward another, the lack of social good will, which destroys social unity and breeds conflict. But as we have already seen, when in society there is the open mind, general social intelligence, strong social sympathy, and a fraternal attitude, such conflicts between classes become practically impossible. Such socially developed democracy is manifestly the remedy, as we have already said, for the class conflicts and revolutions of violence which threaten our world. If our world is one of increasing class conflicts, it is only an indication that our democracy is still very imperfect.

Here we have to note the principle to which all recent writers on democracy call frequent attention; and that is, that it is impossible to sustain democracy in our political life without accepting democracy as a conscious program for all other phases of our social life also. If our industry, our religious life, our family life, and our education are non-democratic, we cannot hope to sustain democracy in political life; for government rests upon these other phases of the social life as its foundation. To illustrate: it is not simply that poverty prevents the normal development of intelligence and character in some elements of a population which makes it dangerous to democracy. It is even more, because it destroys the good will, sympathy, and equality which are essential to fraternal relations in a population. Again, a feudal or autocratic organization of industry breeds class conflict and menaces political democracy because it destroys good will and equality of opportunity. It is the lack of democracy in 
our industry which prevents the formation of a common will in industrial groups-the only possible basis for the permanent settlement of differences between employers and employees. Again it is the lack of democracy in the relations between races which is the chief factor in breeding the racial antagonism that in the United States makes possible race riots and other inter-race maladjustments. Finally, it is the lack of democracy in our intimate social life which divides our society into strata, cliques, and circles, characterized by little understanding and sympathy and hence by little social cohesion. We cannot make political democracy a success without democracy in these wider social relations. Yet political democracy, itself, exists for the realization of this larger social democracy, or else it has no meaning. To achieve such general democracy in all the relations of life, we evidently need, to accompany and sustain it, a religion of democracy, of social idealism, of enthusiasm for humanity.

Perhaps the deadliest foe of all which democracy has is militarism, the use of armed force by one group to conquer another group. This is the absolute negation of that social good will which we have said is one of its necessary foundations. It is a commonplace with students of social history, that war, through all the ages, has been one of the greatest enemies of democracy. All of the autocracies of the world, so far as anthropology and sociology can discover, have arisen in one way or another through war. The reason is not difficult to discover. Democracy, in order to succeed, requires a democratic setting; but militarism tends toward the rule of force and toward the organization of society on a basis of force instead of upon a basis of good will and rational likemindedness. Even defensive wars have more than once resulted in the sub- 


\section{THE RECONSTRUCTION OF RELIGION}

version of democracy both in government and in society at large. Hence democracy stands but little chance of success in a militaristic world organized upon the basis of armed force. National autonomy is threatened so long as there is not established international equality and good will. As long as nations have to arm to the teeth to protect themselves from aggression by other nations, no nation can give proper attention to its domestic questions; military expenditures will eat up public resources, equality of opportunity cannot be maintained, and democracy cannot be realized. The equal rights of nations, not less than of individuals, must be assured if democracy is to win out.

But militarism among the nations cannot be ended as long as their relations are governed by the pagan principles of power and self-interest. There must be developed an international mind and conscience which will demand justice and good will in international relations. But the equal rights of nations cannot be assured if international relations remain anarchic. If good will is to become the basis of human society, it must be organized internationally as well as within national groups. Without such organization, international conscience and good will cannot become effective. The triumph of democracy is bound up with the triumph of a democratic internationalism which will put an end to competitive national armaments and to the rule of force in international relations. Peace, social and international, is necessary for the safety of democracy; and for this reason the world must be federated, organized, for peace.

Yet it is evident that no Association or League of Nations based upon national self-interest and force can give the world lasting peace. Peace, in order to endure between nations as between individuals, must be based upon 
justice, understanding, and good will. A peace of power and self-interest cannot long endure. Our world must achieve something more radical than a League of Nations to secure lasting peace. It must give up the spirit of international suspicion and selfishness; it must develop a spirit of international co-operation and good will. If the world is to be federated for peace, there must be cordial recognition of the fact that all the nations of mankind constitute but a single family, with the real identity of interests which we find among the members of a family. "Pagan" states which recognize only their own selfinterest as their guide cannot possibly form such a union. Such a union can succeed only if backed both by world intelligence and by an active international good will. Democratic internationalism is possible, in other words, only if social religion leads the nations into the pathway of international justice and good will. Thus again we see that "the healing of the nations" must come through humanitarian religion, transforming our politics from a polities of power and self-interest to one of the service of humanity. Only humanitarian religion can do this; but with the establishment of its ideals, international peaco and co-operation will no longer be a problem.

The democratic movement, then, depends for its final success upon the development in our social life of all those things which tend toward social justice, social sympathy, understanding, good will, and peace. It is only through these things that there can be opportunity for the full development of that rational likemindedness upon which the success of democracy, or the rule of public opinion must depend. In other words, to develop scientific knowledge and so diffuse its influence that it will make and guide public opinion requires the co-operative social spirit-the 


\section{THE RECONSTRUCTION OF RELIGION}

spirit of justice, good will, and peace in human relationships. And this, as we have said, requires the cultivation of the spirit of social idealism or social religion. The association of democracy and social religion is, then, no accident. "An ideal democracy," says Professor Cooley, "is in its nature, religious, and its true sovereign may be said to be the higher nature, or God, which it aspires to incarnate in human institutions." 1

While many of the higher ethical religions have been favorable to democracy, yet no religion has democracy so inwoven in its very nature as Christianity with its doctrine of the fraternity and essential moral equality of all men. Christianity may be sald to be the religion of democracy in that it teaches that the service of men, even of the weakest, is the service of God. If Jesus was not the first great democrat, he has been the great teacher of democracy in our western world through all the centuries. Even the most hostile and bitter critics of Christianity have had to recognize the essential democracy of Jesus' teachings. ${ }^{2}$ It is impossible for any sane man to impugn the democracy of one whose test of greatness and of worth was the service of all, even of the weakest. Jesus clearly had not only the ideal of a democratic society but the ideal of a fraternal democracy, the only kind, as we have seen, which will work in the long run. So clearly is the fraternal conception of democracy set forth in the Gospels that modern writers have been able to add but little to that conception.

Just as in the chapter on the economic life, we found at its end that we had done little but elaborate the ethical standards of Jesus in regard to wealth, so again at the

${ }^{1}$ Op. cit., p. 205.

- E.g., Nietzsche. Edward Carpenter, who certainly cannot be accused of any bias in favor of Christianity, acknowledges (Pagan and Christian Creeds, p. 220) its "extraordinarily democratic tendency." 
end of this chapter we find that we have done little but elaborate Jesus' ideal of democracy. Christians who take a social view of their religion at all, cannot fail to see this, and its corollary that the realization of social and political democracy is an essential part of the program of Christianity. This has often been denied; and the incident in which Jesus told the Jews to pay their taxes to the Roman government is cited to show that Jesus did not mean that his teachings were to have any bearing upon political life. But this is surely an absurd interpretation of that incident. Whatever Jesus intended to teach on that occasion, it is certain that he did not intend to teach that religion was to be divorced from the political life.

The hunger and thirst of the modern world after democracy is surely a hunger and thirst after the kingdom of God,-if we make allowance for the perversions which unavoidably creep into all great movements. The most hopeful thing in the social and political life of our day, in other words, the thing which shows most unmistakably the influence of the religion of Jesus, is the democratic movement. It is surely time that religious people recognize that a fully democratic world will be a long step toward a Christian world; and on the other hand, those who believe in democracy should recognize that democracy can only be safe in a world which has Christian aims. It is Christian Democracy which must ultimately solve the social problem. 


\section{CHAPTER $\mathrm{X}$}

RELIGION AND SOCIAL PLEASURE

A RELiaron which is adapted to the needs of human life must have a clear and uncompromising doctrine concerning social pleasures and amusements. Individual character and the character of civilization depend quite as much upon the manner of spending leisure as upon the serious work of life. Not serious occupations, indeed, but play and amusement too often have the preponderant rôles in determining moral character in the young. ${ }^{1}$ Until men learn to spend their leisure nobly, to order their social pleasures rightly and rationally, it is idle to think that; they can develop high moral character as individuals or create a civilization of beauty and righteousness. Hence, a social religion, whose chief concern we have seen to be the making of men, must fearlessly oppose all forms of social pleasure which degrade and brutalize the individual or which barbarize the standards of society. It must furnish active leadership in promoting ennobling forms of social pleasure.

Social welfare is endangered by all forms of pleasure which tend to subvert or undermine the higher controls which civilization has developed over individual behavior. To be specific, whatever in social pleasures and amusements weakens the family, corrupts morals, sneers at re-

1 "The three master forces," says Professor Ross, "fixing the mundane welfare of human beings are Work, Living Conditions, and Recreation" (in R. H. Edwards, Popular Amusements, p. 5. This book outlines the whole probl $m$ of public amusements and recreation and contains good bibliograytilies). 
ligion, hinders education, or tends toward the defiance of law or the creation of race and national prejudice, delays the realization of a Christian social order, and should receive the fearless condemnation of social religion. If social religion is a set of practical attitudes toward practical problems, as we have said, then there is no more urgent problem in our society than the securing of ethical forms of play and amusement.

For play and amusement are most necessary things in our social life. Upon them, not less than upon serious work, the whole structure of higher civilization has been built. Through play and amusement the young get not only physical and mental development, but also a very large part of their social education. Through play and amusement, the hard work of life is rendered tolerable for adults. The need for relaxation in our strenuous industrial and business life is especially intense. Through play and amusement the adult human mind gets not only much of its essential development but rest and refreshment, and the human body, also. These things are thus biological as well as social necessities, ${ }^{1}$ and hence even in the briefest outline of an adequate social religion must receive considerable attention. Moreover, their possibilities in the development of human social life have not yet been thoroughly explored. There is good reason to believe that when we have mastered the creative forces latent in play and amusement, education will be easier, social life more joyful, and civilization itself more humane and beautiful. Social religion must seek to control social pleasures so that they will work in this socially constructive direction.

${ }^{2}$ An admirable brief presentation of the sociological theory of recreation will be found in Ross' Principles of Sociology, Chapter LII (pp. 604-616). 


\section{THE RECONSTRUCTION OF RELIGION}

Yet notoriously, social pleasures and amusements in our civilization have continued to remain on the pagan level. Too frequently they even show the same degradation which characterized those of decadent Rome. This may be due in part perhaps to the animal impulses of original human nature which well up in all of us and especially in the young. These animal impulses hurry us back, when over-stimulated, to the barbarous level of behavior. Original human nature, ${ }^{1}$ we must always remember, is animal nature. While there is no scientific warrant for a doctrine of original human depravity, as that doctrine has been ordinarily understood, yet science reveals that the original nature of man was non-moral. because it was an animal nature. The civilized nature of man is wholly acquired, and is acquired only by intelligent effort and maintained only by constant vigilance. Hence the animal impulses of man's original nature under certain conditions favor reversions to the savage and barbarous levels of behavior. This must be borne in mind when we consider the nature of the amusements which civilized society can afford to approve. Many amusements in our present society cause the participants to lose the control which civilization has put upon the original animal impulses, or primitive passions, of man. Society cannot afford to tolerate this. Social sanity requires us in all the relations of life to beware how we release these primitive passions, and this is especially true in our social pleasures and amusements.

But the greater reason, by far, for the prevalence of

${ }^{1}$ Professor Cooley and also Professors Park and Burgess (in their Introduction to the Science of Sociology) use the term "human nature" to mean the nature acquired by man in association with his fellows, especlally in the primary groups. To differentiate, we have used the term "original nature" to mean the inborn, hereditary nature of man, which according to evolution was an animal nature. 
pagan standards in the social pleasures and amusements of our present civilization is the survival of those standards in our social habits and traditions. As we have seen, the whole tradition of our civilization has remained largely pagan down to the present in spite of the nominal acceptance of Christianity. Imbedded in the very heart of our civilization, we have seen, is the tradition that power and pleasure are the chief ends of life, a tradition characteristic of barbarism. Hence, self-indulgence and the gratification of animal appetites and impulses in socially destructive ways is one of those surviving traditions of barbarism among us of which we have not yet been able to rid ourselves.

There have been many reasons, of course, why we have been unable to get rid of this tradition and put our standards of social pleasure and amusement on a Christian basis. One is the survival of the other traditions of barbarism among us which we have already pointed out, ${ }^{1}$ such as autocracy, militarism, economic exploitation, and the like. Another reason is that the tradition of barbarous self-indulgence and unsocial gratification of animal impulses and appetites has become associated with certain forms of economic profit-making which deliberately aim not only to keep alive this tradition, but to make it dominate social pleasure and amusement in general. ${ }^{2}$ It is especially commercialized pleasures and amusements, in other words, which present a peculiarly threatening problem in our civilization. Too often, as Miss Addams says, the "Anglo-Saxon city has turned over the provision for

1 See Chapters III and IV.

2 The deeper reason, therefore, for so many apparent reversions to the animal level in social pleasures is our defective social system, especially our defective social control. This problem is, of course, the problem of the whole book, but see especially again Chapters VII and VIII. See the argument beginning on page 268 also. 


\section{THE RECONSTRUCTION OF RELIGION}

public recreation to the most evil-minded and most unscrupulous members of the community" 1

We should beware, however, of thinking that by getting rid of the element of private profit in amusements wo would thereby solve the problem of rational social pleasure. All the evidence points to the opposite conclusion. Under all conditions of culture individual men have been prone to indulge their animal appetites at the expense of society; and we know of no social state in which this tendency has been held in restraint without some form of social discipline. Wherever social discipline has decayed, riotous forms of pleasure and amusement have, as it were, spontaneously broken forth, probably not so much because: of original human nature, however, as because of the survival, as we have already pointed out, of certain traditions favoring selfish indulgence. Yet we must admit that human nature with its animal impulses must be favorable to these traditions of selfish indulgence, or else it would not accept them so readily.

Here then we see the real reason for the prevalence of so many degrading forms of pleasure and amusement in the modern world: it is the decay of social discipline. Anything that favors the lowering of social morale, in a word, favors to some extent the recrudescence of brutalizing pleasures and amusements. We have, to some extent, lost our social morale, because in the new and complex world in which we live old forms of social discipline have proved inadequate and have decayed. We need a new and higher morale, as we have already pointed out, ${ }^{2}$ to meet

1 The Spirit of Youth and the City Streets, p. 7. The conclusion of Miss Addams that proper provision for rational recreation should be a public function is one to which practically all sociologists and social workers would agree.

See Chapter II and Chapter V. 
the subtle temptations which modern life with its wealth and power too often affords; and nowhere is this need more in evidence than in our social pleasures and amusements. Our world presents the amazing spectacle of more lives offered upon the altars of pleasure than upon those of war, famine, and pestilence combined. The lives utterly ruined, or their social usefulness at least destroyed, by the pursuit of foolish pleasures are so numerous that no attempt is made to keep track of them. Here we must reckon, for the most part, the victims of drink, of sexual immorality, of gambling, and of many other low forms of sport and amusement. The wasted energy is beyond computation. Obviously civilization cannot go forward with such a drag. A new social discipline must be provided which will safeguard the young and the adult alike from the insidious unsocializing influences of low forms of pleasure and amusement. In part this social discipline may be provided by purely secular education; but social religion, as we have seen, ${ }_{1}^{1}$ must be the chief reliance in any group which desires to maintain a high social morale. Hence the social education of the young should be completed and crowned by an adequate religious education if we expect them to be able to resist the temptations to low forms of pleasure and amusement which go with wealth and leisure as well as with poverty and overwork.

It will be at once objected that religion has conspicuously failed as a means of securing wholesome and rational social pleasures and amusements in the past. Religion, it may be said, has always wrestled with this problem, and if it has not succeeded in the past, what right have we to think that it will be of any help for the future? Again and again, to use the Spanish proverb,

${ }^{1}$ See p. 179. 


\section{THE RECONSTRUCTION OF RELIGION}

"Human nature has been driven out with a broomstick and has come back with a pitchfork." The prohibitions and taboos which religion has imposed upon social pleasures and amusements have proved to be vain and have obscured rather than clarified the problem. The reply is that obviously the religions of the past, while right in their apprehensions in regard to social danger from unsocialized forms of pleasure and amusement, have not been scientifically guided; and that there is no reason to argue that because undeveloped religions have failed in solving this problem this will necessarily be the case with a fully developed social religion. No doubt the religions of the past, and historical Christianity in particular, have made the mistake of taking too negative an attitude towards social pleasures and amusements. ${ }^{1}$ They have seen their danger and have gone to the opposite extreme of endorsing asceticism, which we may define as the doctrine that all the animal impulses of man are in themselves evil. Asceticism does not help to solve the problem of social pleasure and amusement because it gives rise to an almost entirely negative and repressive attitude toward these necessary elements in a normal social life. A social religion working in harmony with social science will adopt towards them a positive, constructive attitude.

This is not saying, however, that a social discipline which is adequate to deal with this problem of social pleasures and amusements will not have its negative and repressive side. This is involved in every form of social control over every phase of social life, or else there could be no control. Indeed, social science with its doctrine of social control over all the conditions of life, and social

1 Religious people have often forgotten, to borrow a phrase from Miss Addams, "that recreation is stronger than vice and that recreation alone can stifle the lust for vice" (The Spirit of Youth and the City streets, p. 20). 
religion with its ideal of a perfected human society point unquestionably to what we might perhaps all agree to call a New Puritanism, if so many shallow minds did not harbor a prejudice against the word. The New Puritanism which is bound to come, if social progress continues, will not be like the old Puritanism, which was accused of taking its pleasures sorrowfully; but it will be like it in that it will demand-the purging of existing Christianity from its pagan elements and the conforming of personal conduct to higher spiritual and social standards. These standards for the New Puritanism, however, will come from modern science, and not from mistaken ascetic ideals of life.

A single illustration will suffice. Science is determining exact standards regarding the relation of alcoholic beverages to human welfare. When these standards have been determined, unless we are going to remain in a barbarous and unscientific stage of social development, they will unquestionably be accepted by the social conscience and enforced by the standards of society. People may plead for alcoholic beverages as much as they please on the score of individual liberty, social pleasure, or social congeniality. Scientifically determined standards are, nevertheless, bound to rule social policies in regard to alcoholic beverages sooner or later if social progress continues. The same thing must be said regarding those forms of pleasure which are connected with sex.

The social sciences are steadily moving forward in the determination of rational social standards along all lines of social pleasure. There is, indeed, no necessity of discussing these standards here at length and in detail. The literature of the social sciences affords ample discussions along this line, and we can expect that scientific research, if allowed to proceed, will establish clear social standards 


\section{THE RECONSTRUCTION OF RELIGION}

regarding all forms of social pleasure and amusement within a generation or two, as it has already done for the use of alcoholic beverages. The main thing to insist upon is that here again social religion must work with social science to secure rational control over the whole of human life in order that a better human world may come into existence.

But certain general principles which should guide us and which should be emphasized by social religion may be pointed out. The specific standards demanded by social science for the control of social pleasures we shall not discuss; but the mere general principles which are as old as humanitarian ethics and religion, need constant reemphasis if religion is to function socially. What are these principles? We may lay down at least four, which, however much their specific application may be debated, would be unquestioned by sound social science or social religion.

The first of these general principles which should guide us in deciding what social pleasures a Christian civilized society can afford to tolerate is that pleasure should always be recreative. That is, social pleasures should be such as to build up body and mind. They should rest, restore, recreate. One of the severest indictments against many of the social pleasures of present society, as we have seen, is that they wear out body and mind, sapping the energies of those who engage in them. Such pleasures of course do not prove truly pleasurable in the long run. They are to be especially condemned because they destroy that very surplus of physical and spiritual energy from which all the higher achievements of civilization must come. Moreover, they are wholly unnecessary. There is an abundance of simple pleasures which restore 
and energize both body and mind. Such, for example, are outdoor athletic sports when rightly conducted. The recent tendency of our civilization to encourage the development of athletics and of outdoor games and amusements is undoubtedly a tendency in a most wholesome direction. Especially should guided and supervised play for children in the parks and playgrounds of our large cities deserve the hearty commendation and support of all socially minded persons. ${ }^{1}$

But this first principle, that social pleasures should be recreative in their effects, is not sufficient for us as a criterion to judge whether a form of pleasure is adapted to social needs. Pleasures may be recreative for the individual and yet harmful to social welfare. The effects upon others must always be taken into consideration, even upon the weakest member of society. Social obligation is paramount to individual interests in this matter of social pleasures as well as in all other matters. Hence, our second principle which is that social pleasures should be unselfish, that is, controlled by a sense of social obligation. After all, it cannot profit us in the highest sense to destroy or injure others in order that we may have pleasure. That violates, as we have seen, the fundamental law of human association. Hence social pleasures and amusements should be those which the community can approve and which can be shared by all. Accordingly they should be open and public so far as possible, and free of access to all.

This does not mean that social pleasures and amusements should be taken out of the home but rather they

1 Statistics show that wherever these supervised playgrounds exist in large cities there has been a marked decrease of juvenile delinquency. 


\section{THE RECONSTRUCTION OF RELIGION}

should be such that all homes may participate in them. They should be such, moreover, as to serve the welfare of every class in the community and not just one class. They should build up, in a word, the life of the community, of society, of humanity, as well as restore the body and mind of individuals. Selfish pleasures, like exhausting pleasures, are unnecessary and short-sighted. There is an abundance of pleasures which we can share with others and which, because they are so shared, give us more lasting pleasure as well as add to the happiness of the world.

This brings out the third principle by which we should judge social pleasures and amusements, and that is that they should be educational. We mean that they should. tend to build up the right sort of social eharacter in individuals. More and more sociologists are coming to agree, we have noted, that the best way to judge institutions is by their educative effects upon human personality. Nothing would do so much to straighten out the problem of social pleasures and amusements as to adopt this same criterion for judging them; and surely a society which is aiming at a higher culture must adopt this criterion. Unless pleasures and amusements socialize, develop higher intelligence and character in individuals, they easily become dangerous to higher social values. Some may say that if all social pleasures and amusements were educative, they would lose their recreational value; but this is not so. Plainly athletics, games, music, the drama, and all other legitimate amusements may be morally educative and yet at the same time highly recreational. Indeed, creative effort itself, while always highly educational, has been found to be entirely consistent with proper recreation for both children and adults. We need to put more intelligence into our social pleasures. There is little excuse, 
except the general barbarity of our civilization, for the low moral and intellectual plane of prevalent social pleasures and amusements.

This brings us to the fourth principle which should guide us in the selection of social pleasures, that they should be spiritual; that is, they should not be merely sensual or animal, but the higher mental and social elements should dominate in them. Whether the pleasures be those of commonplace life or of art, they are saved from animalism only by the dominance in them of the higher mental and social elements. The spiritual, however, is not something apart from the things of which we have already spoken, but rather a proper combination of them. Pleasures that are recreative and at the same time unselfish and highly intelligent are spiritual. They make toward the higher development of the mental and social traits of man, or, as we say, of his spiritual life. The validity of this ideal of social pleasure has often been denied, but it may be pointed out that the pleasures of which we are not ashamed, which we go out of our way to promote, are of just this character. Such pleasures are consistent with the highest social religion.

If all of our social pleasures ana amusements were truly recreative, unselfish, educative, and spiritual, there would be little or no problem in connection with them, except how we might best promote them. But our social pleasures and amusements are not now of this character. How can we lift them to this plane? In part we have already indicated ways of doing this. But the problem remains how certain forms of social pleasure may be redeemed and put upon a highly moral and social plane. The church must take its full part in this redemptive 


\section{THE RECONSTRUCTION OF RELIGION}

work. If provision for rational social pleasure and amusement is to be a public function, then such provisions can best be developed in many cases in connection with the churches and schools. Just how much each church should provide for the wholesome recreation and amusement of its attendants depends, of course, upon local circumstances. The church in the crowded conditions of city life will naturally develop in the direction of making direct provision for these. So, too, probably the church in the isolated rural regions. But whether the church undertakes directly such activities or not, it is the function of social religion to provide leadership in such matters. It must undertake the redemption of the amusements and pleasures of young people in particular. To this end churches must concern themselves with promoting facilities for wholesome recreation. Social religion must in this matter, as in so many others, lead especially through creating public opinion and public conscience. That is its true function, and the chief method of its program of social redemption.

It may be suggested that if more of the element of art entered into our social pleasures and amusements we would thereby regenerate them and more easily adapt them to the needs of higher civilization. If the dance, for example, which is now so frequently associated with indecency and immorality, could be put upon the level of true art, most of the objectionable features now so frequently associated with it would probably disappear. The stage and the moving picture show need quite as much to be touched by the spirit of true art to effect their regeneration as to be made regardful of the principles of morality. The spirit of art alone cannot, of course, produce the socially right; but it is certain that true art and 
the spirit of social idealism may work hand in hand. Nothing would help therefore more to solve the problem of social pleasures and amuscments than to infuse in our people of every class a love for and appreciation of true art. If we had this love and appreciation of true art reigning in our civilization, it would be found that the pursuit and enjoyment of the fine arts would spontane- 1 ously tend to eliminate many of the more barbarous social pleasures and amusements to which people now devote their energies.

Many problems concerning recreation and amusements, which now trouble us, would straighten themselves out if we could put our social pleasures on the high plane which we have described. We would, for example, have littlo or no problem concerning the proper use of Sunday, and we should need no Sunday "blue laws" to prohibit pleasures and amusements upon that day. It must be obvious that pleasures and amusements which are demoralizing on Sunday are equally demoralizing on week days, and only a very inconsistent civilization could prohibit them on Sundays and tolerate them on week days. Pleasures that are at once recreative, unselfish, educative, and spiritual are manifestly appropriate for the Christian Sunday or Sabbath. For the Sabbath, as Jesus said, is made for man. This is not saying, of course, that it is not wise and even socially necessary for a people to set apart one day out of seven primarily for the consideration of moral and religious truth. The Christian Sabbath is not primarily a "recreation day," or a "rest day," except as rest is secured by attention to the higher things of life. It is primarily a day for education in these higher things, with which social religion concerns itself. But there should be the same place in it for rational social pleasures and 


\section{THE RECONSTRUCTION OF RELIGION}

amusements as on other days. Week days are not primarily for social pleasures and amusements, neither are Sundays. Both week days and Sundays should be dedicated to the serious purposes of life; Sundays, to the higher spiritual life, week days, to the ordinary business of life. We cannot afford to tolerate on week days, however, pleasures and amusements which will detract from and perhaps undo all that we gain in a spiritual way on Sundays. Pleasures and amusements on Sundays should, of course, be consistent with the high purposes of the day, but this is best achieved not by repressive legislation but by appeal to the conscience of the individual. We should, at any rate, not tolerate on week days pleasures and amusements which we are afraid to have enjoyed on Sundays.

Plainly the principles which should guide us in our choice of social pleasures and amusements, that we have just laid down, are those implicit in Jesus' teachings. A religion and ethics of the service of God through the service of humanity, such as Jesus taught, obviously implies that in our pleasures and amusements we shall seek to build up the total life of humanity. This we cannot do if our pleasures and amusements are such as to weaken or destroy bodily strength, injure the rights or the happiness of others, stultify intelligence, or encourage the sensual and animal in us. Jesus has often been accused of being ascetic in his outlook on life; but there is little or nothing in his life and teachings to warrant such a charge. He not only mingled in the social life around him but shared in the social pleasures and amusements of his time to such an extent that he brought down upon himself the censure of the moral rigorists of his day. This censure was, however, quite as unwarranted as the 


\section{RELIGION AND SOCIAL PLEASURE 279}

present charge of asceticism. The teaching and life of Jesus seem to illustrate so perfectly the normal place of social pleasure in a normal life that again modern science can add but little to the fundamental principles which he made evident.

It must be true Christianity, or the religion of Jesus, which will solve the problem of social pleasures and amusements in our society. When our social life is suffused with the spirit of Jesus' teachings, there will be no perplexing problem left in regard to such matters. Not legislation, but religious and moral education, education in the principles of social religion and ethics as laid down by Jesus, must solve this problem. 


\section{CHAPTER XI}

\section{THE OPPORTUNITY OF THE CHURCH}

THE church is the institution organized to embody concretely the religious life of society. It is co-ordinate in importance with religion itself; for if religion is to be a vital influence in social life it must find concrete embodiment in some institution. Only through suitable organization can the religious life express itself and bo developed in the mass of individuals. While it is a great mistake to make organization an end in itself, yet it is an equally great mistake to think that the religious life should not be organized. ${ }^{1}$ To some extent, it has always been organized, because the religion of the most primitive peoples is of a congregational or communal character. The more highly developed a religion is, the more pronounced will become its institutional character and the more completely will it become organized. A religious life without organization would be non-co-operative, non-social, and individualistic. It could not be representative of social religion in the fullest sense. ${ }^{2}$ It would be like a political or economic life which was unorganized. Just as men find organization indispensable in their political and economic life, so too men find organization indispensable in the religious life.

'See Chapter V, p. 131.

- It should be remembered that developed religion is always a social product and functions socially. See Chapter II. 
The church is the institution which stands for the organized religious life of men. Without it, that life would be powerless and utterly incapable of transforming human society. The church exists to serve the great interests of religion in society, that is, to serve those ideal values for which religion should stand. Therefore the social function of the church is to conserve and propagate religious and moral ideals in human society. Its great business is to bring before men the demands of the higher spiritual life. Its function, in a word, is to be the "spiritual power" in human society. Other activities than the teaching and propagation of moral and religious ideals may, of course, demand its attention; but that that is its main business cannot be doubted.

Viewed from this standpoint, the church is the most important of all human institutions. The Christian church in particular is charged with the task, not only of creating Christian character in individuals, but of establishing the kingdom of God upon earth. However imperfectly it has performed its task, it is, in a sense, the most remarkable of institutions. For here is an institution devoted avowedly to social idealism, to the re-making of human character and of human institutions themselves in conformity with the divine ideal. Whatever the faults of the church, surely no other human institution bears such witness to the idealistic aspirations of mankind. It is no accident, therefore, that many of the noblest, most aspiring, most unselfish spirits of our race have found their work in the upbuilding of this institution; and we shall try to show that it was not foolishness on their part, eren though the institution itself was inadequately organized to achieve its purpose, and though they were unguided by scientific principles in working out the difficult tasks which they set before themselves. 


\section{THE RECONSTRUCTION OF RELIGION}

But all institutions have an insidious tendency to forget the purposes for which they were originally organized and to set themselves up as ends in themselves, or else be diverted to side issues. Historically, as we have seen, this has often been the case with the Christian church. Indoed it could not have been otherwise, because the church is a human institution and subject to all of the errors which its human constituents may make. Institutions, as we have seen, like individuals, necessarily learn by the trial and error method. Yet it would seem that the Christian church should, by this time, have learned enough by the mistakes of the past to set itself square with its stupendous task.

There is urgent need in our world to-day of a new, reunited, re-vitalized Christian church, which shall take up anew, with the faith of its founder, the task of redeeming the world. Never was the church less fitted in some ways, however, for this great task than at the present time. Divided within herself, with her faith often cold, with pagan standards and worldly interests too often ascendant within her, it is no wonder that some of her noblest spirits despair of the church's being equal to her opportunity. It is not that the church is worse-for certainly never before were there so many within her who perceived clearly the truth-but that the opportunity and the responsibility have suddenly become so much greater.

Unless there is renewed vision, renewed consecration to the work, and new and clear understanding of all facts and forces, the church cannot succeed in its stupendous task of redeeming the world. Yet if it fails, we have no good ground for believing that any other institution can succeed. The church, as the torch bearer of social idealism, must lead the way if other institutions are to follow in the work of the social redemption of mankind. What 
then must the church do to fit herself for leadership in this supreme work which is committed to her charge?

First of all, the church must become united within itself. It cannot preach a gospel of reconciliation successfully unless it can illustrate that doctrine in its own life. It cannot reunite a divided world as long as it remains divided and warring within itself. ₹ It cannot expect to bring about the federation of the world for peace as long as peace and co-operation do not reign within itself. This does not mean that there shall not be liberty within the church. The unity which the world demands of the church is a unity of co-operation in the work of saving mankind. Such unity will leave liberty in nonessentials, such as denominational theological beliefs and ritual practices. The unity of the church in the work of redeeming mankind must be a practical unity, a genuine brotherhood in service, which transcends and tolerates differences in these non-essential matters.

Such unity should be conceived in a broad enough spirit to include all who are working for the establishment of a Christian world. Not only should it be possible for all branches and denominations of the Christian church to form such a unity, but there is no reason why any church organization which is willing to work for this end should be excluded from such a working unity. Not only should Catholic and Protestant find it possible to co-operate within such a church universal, but also Jew and Christian. It must be remembered that the Jewish Synagogue is the mother of the Christian church, and that the religion of the later prophets of the Old Testament is essentially the religion of Jesus. Moreover, at the present time, there are many Jews who are more Christian than many so-called Christians, and many Christians whose 


\section{THE RECONSTRUCTION OF RELIGION}

religion is more that of the Old Testament than that of the New. On the other hand, it is unfortunately true that there are still many Jews who shy at the very word "Christian," or at anything to which it may be applied, so much do they still confuse genuine Christianity-the teaching of Jesus-with the persecutions which they have suffered at the hands of those who wrongly claimed to represent it. We may agree, indeed, with a leading Jewish scholar ${ }^{1}$ when he says, "The long waited for reconciliation between Judaism and Christianity will come when the teachings of Jesus become the accepted maxims of human conduct." Not until Christians become more completely Christian, in a word, can we expect the Jewish church to see the truth that is in Jesus and to unite heartily with all Christian denominations in working for a Christian world. Already there are signs, however, of such a movement, and it is certain that nothing would hasten it so much as the full establishment of the religion of Jesus within the Christian church. For, as one of their liberal religious thinkers says," "The Jew cannot help hoping that Jesus may yet serve as a bond of union between Jew and Christian, once his teaching is better known and the bane of misunderstanding at last is removed from his words and his ideal."

As to Protestant and Roman and Greek Catholic, there should no longer be difficulty in their working together at the common task of the church. Liberalism is slowly but surely rising in both the Roman and Greek Catholic churches; and in both the essential teaching of Jesus is coming so to the front that they sometimes put to shame Protestant churches by the advanced programs of social justice which they put forward. Any one who knows these

1 Professor Morris Jastrow.

"Rabbi H. G. Enelow, A Jeroish View of Jesus, p. 181. 
churches knows that within them are found many of the truest Christians of our present world. However much Protestants may feel themselves forced to criticize and condemn the ecclesiastical organization and methods of these older denominations, they should perceive the true Christian spirit at work in these churches, encourage it by their fraternal co-operation, and trust to it to work out the problems of internal reorganization and regeneration. Great movements within the Roman and Greek Catholic churches attest that such internal regeneration is already going on, and Protestants should remember that they hare enough to do in setting their own household in order. Again we may paraphrase and say, when the teachings of Jesus become the accepted maxims of all churches, the long waited for reconciliation between Protestants and Catholics will come. Obviously the way to bring this about is not to debate or argue, but to enter into such relations of co-operation as the spirit of love which Jesus taught would prompt.

As to the relations of Christianity and the non-Christian religions, we have already seen that there is every reason to believe that when the true Christian spirit once fully dominates the Christian church, it will gradually permeate and transform the non-Christian religions so far as they are capable of surviving under conditions of true civilization. As Dr. Josiah Strong said, "When Christendom has been Christianized, we may expect the conversion of pagandom-and not until then." 1 Christian churches should therefore not hesitate to co-operate with non-Christian bodies in the attainment of Christian ends, as that is the best way to develop in both the true spirit of Christianity. Deeds always count for more than pro-

${ }^{1}$ The New World Religion, p. 503. 


\section{THE RECONSTRUCTION OF RELIGION}

fessions in human life. Indeed, as we have already pointed out, ${ }^{1}$ the very basis for membership in Christian churches themselves should be this practical co-operation with the church in Christian work. It should be an intelligent willingness to co-operate with the church in its work of redeeming mankind rather than a submissive acceptance of theological dogmas. It should mean for the individual full personal consecration to the Christian cause through the service of mankind.

Many of the best minds of the church shrink from this broadly tolerant Christian attitude. They fear that it may lead to the toleration of wrong and of error, or at least to a flabby and shallow religious life. Nothing could probably be further from the truth than such a supposition. It is the practical social attitude in religion more than anything else which will drive paganism out of our churches. It has been theological Christianity which has tolerated practical paganism in the church, covering it with the cloak of respectability by making the acceptance of a theological creed count for so much. The result has been, to quote an orthodox Christian minister, "What we call the Christian church is more or less that only in name. The most outstanding fundamentals of Christianity, as Jesus taught it, have either been so completely lacking in it or so adulterated with self-seeking that they have been able to function but little." Such a condition can be overcome only through the teaching and practice of an aggressive social Christianity-through reawakening the spirit of Jesus in every church member.

The "hospital" conception of the church, which has so disgraced Protestantism, should be given up. The primary business of the church is not to heal the physically

${ }^{1}$ Chapter V, p. 159. 
or spiritually sick or to give spiritual or physical comfort to its members. Such a conception makes the work of the church individualistic and selfish; and such individualism and selfishness in religion is hostile to the spirit of Christianity and perpetuates paganism in the church. ${ }^{1}$ The ministry of the church to the individual is incidental to its main work, which is that of the establishment of the kingdom of God among men. Like an army, the church will look after the health and welfare, physical and spiritual, of its members; but like an army, it will constantly remind its members that their individual welfare and comfort is not the chief end sought.

Even the conception of the church as an individualistic educational institution is quite inadequate. Individual religious and moral education is, to be sure, the foundation of all of its work. Without this foundation it could not become an organized spiritual power for the redemption of mankind. It must devote itself to the ethical and religious culture of every member in order that every member may be fit for the largest human service. Until Christianity is effectively taught to every one who is brought under the influence of the church, we cannot expect that Christian ideals will be carried out. Much evidence goes to show that Christianity has never been effectively taught or even clearly presented to the mass of church members, to say nothing of the mass of the people at large." "We have known," says Professor Coe,

1 See Chapters III, IV and V.

2 The Committee on the War and the Religious Outlook of the Federal Council of Churches in America published a report of their careful investigation of the religious condition of the men in the American army, entitled Religion Among American Men: As Revealed by a Study of Conditions in the Army. The gist of this report is given in the following quotation: "If there is any one point upon which the chaplains agree it is in regard to the widespread ignorance 


\section{THE RECONSTRUCTION OF RELIGION}

"that spiritual illiteracy abounds in the churches themselves. The ideas of church members concerning the significance of their membership, like the ideas of the general populace concerning the Christian religion, are partly vague and partly miscellaneous and unco-ordinated." 1

Every Christian church should manifestly be a teaching church. From one point of view, this is its supreme work. Only we need to remember that teaching is not an end in itself. The end which is sought by teaching, after all, is a practical end-the transformation of human conduct and of human institutions. Education is a means and a method, not an end in itself. The church must be truly an educational institution, and until it recognizes itself, and is recognized as a fundamental educational institution, the church will not function rightly, nor will human society be right.

The relation between the church and the school is therefore a very close one, and should be much closer than that which exists in American society at the present day. We need not go to the extreme of making the church absorb the school or the school absorb the church, as that is opposed to the principle of the division of labor in social evolution, which holds for institutions as well as for individuals. But there can be and should be the closest cooperation between the school and church. The church has, in a sense, the most important education of all to carry out for our youth-the education in the higher social

as to the meaning of Christianity. ... We might well hope that in a "Christian" country men generally, even those without any allegiance to Christ or His Church, would know what Christianity is. Chaplains say that they do not know. And they go beyond that and say that men nominally within the Church, men who have been to Christian schools. are in much the same condition. The Church as a teacher has failed to instruct its own membership." (Italics mine.) "Journal of Religion, January, 1921, pp. 20-22, in a very striking article on "The Religious Breakdown of the Ministry." 
values, in moral and religious ideals. Every church should therefore organize itself as a teaching church. Its classes, moreover, should not be merely for children and adolescents. The whole church should be kept constantly mobilized for study - the study of the principles of Christianity on the one hand, and of the actually attained Christian living or the lack of it in the world, on the other. Thus Christianity and the cause and the work of the church could be kept constantly before the mind of every church member. In such a church, every individual would be in training for the larger work of the church and the maximum number would be kept fit for that larger service.

It is evident that the work of the church in the education of individuals is so completely bound up with the larger work of which we are about to speak that it cannot be separated from it, and we shall have to return again to this subject as the foundation of all of the work of the church. Before leaving this topic we cannot but remark that there would be little or no need for emotional revivals to call the attention of men to the value of Christian living, if every child could be brought up in the church and given Christian ideals of life to start with. Under such circumstances there would be no need of those emotional crises which we have come to associate with the very word "conversion." Such conversions, psychology shows, are unnecessary in the proper development of the moral and religious life, are largely a waste of energy, and often ineffective for the production of true Christian living.

If the business of the church cannot be summed up as looking after the physical and spiritual welfare of its members, or even as educating them into Christian ideas 


\section{THE RECONSTRUCTION OF RELIGION}

and ideals, what then is its work? Plainly its final work, as we have so frequently said, is the social redemption of mankind-the creation of a Christian world. 'But this means something more than a ministry to individuals as individuals. It means the transformation of customs and institutions. It means the shaping of the policies and conduct of groups as well as of individuals. Beyond the church's mission of individual evangelism is the church's mission of social evangelism. (The subject of redemption is not the individual, but the world of individuals. ] How can the church undertake this larger work of social control to secure the social redemption of mankind?, Manifestly the church must undertake to deal not only with individuals, but with mass movements and the forces that lie back of mass movements, which we vaguely call public sentiment, public opinion, and popular will. The church must undertake the work of creating conscience, a public conscience, upon the behavior of groups as well as of individuals. ${ }^{1}$ Not until the church is willing to grapple with this problem, which we might call that of "Christian statesmanship," can it create a Christian world.

It must be evident to all who desire a Christian world, ${ }^{2}$ that if such a world is ever to become a reality, the church, animated by the true spirit of Christianity, must assume the moral leadership of the opinion of mankind. A Chris-

1 This conception of the work of the church was first plainly set forth by Dr. Samuel Zane Batten in an article on "The Church as the Maker of Conscience" in the American Journal of Sociology for March, 1902 (Vol. 7, pp. 611f). Compare also his book, The Social Task of Christianity. The conception of the work of the church as the creation of public conscience is, of course, closely allied to the conception that the work of the church is chiefly prophetic. However, the former expression is to be preferred as less ambiguous and more in line with the terminology of the social sciences.

${ }^{2}$ From this point on the substance of this chapter was presented in a paper before The Religious Education Association at its Pittsburgh meetlng in March, 1920. See Religious Education for April, 1920 . 
tian society, we have seen, cannot be realized by merely developing Christian character in individuals. That has been a mistaken idea of the Protestant church. "No individual," says one of the profounder social thinkers of the present," "can change the disorder and iniquity of this world. No chaotic mass of men and women can do it." Such change can come only through public opinion, organized popular will, and social control. The transition from non-Christian society, then, to Christian society can only be effected by the formation and guidance of an effective public opinion which shall express itself in an appropriate mode of social control, because that is the only mechanism through which conscious social changes are effected in human society. "Individual education, individual conversion, individual' repentance, and the whole development of individual Christian character are, of course, necessary foundations; but if the church desires a Christian world, it must have a vision of its work beyond these fundamentals. It must see that its higher work is the creation of public conscience-that is, an effective public opinion-regarding the conditions under which men and groups of men live together. It is only thus that a Christian world can come into being.

There can be no doubt about the power of public opinion to make a Christian society, and ultimately a Christian world; the only doubt is, as to whether the Christian church will use its opportunities to make, guide, and control public opinion. Probably no one would claim that there has been much organized effort on the part of Protestant churches in the United States in the past to guide and control public opinion, ${ }^{2}$ unless it be along a few lines,

1 Miss Mary P. Follett, The New State, p. 101.

"See the "Social Creed of the Churches" in the Appendix, adopted by the Federal Council of Churches of Christ in America, represent- 
like the suppression of the liquor traffic. Yet this is exactly what all Christian churches must undertake if there is ever to be a Christian world. They must go into the business of creating an effective public conscience regarding all relations of individuals, classes, nations, and races. The cry of the world is for Christian churches to go into this business at once. If the world is to be saved for Christianity, the churches must soon become more effectively organized for the guidance and control of public opinion. Only thus can a Christian environment be created for the nurture of Christian character.

For there can be no doubt that in civilized societies public opinion is the chief power which lies back of institutions, laws, and the "mores" or customs, since these things, sociology shows, are social habits which have been reflected upon and sanctioned by group opinion as necessary for group welfare. ${ }^{1}$ In democratic societies, especially, public opinion plays an increasing rôle; for democracy, we have seen, is essentially the rule of public opinion. The social life of the future, which will undoubtedly be democratic, is destined to be more and more dominated by public opinion. We live in a world which is more and more ruled by public opinion. If we want a Christian society, therefore, the church must capture public opinion for the Christian program.

Let us see clearly the reasons why this is so. Public

ing thirty Protestant denominations. However, after careful investigation the author has been convinced that not one member of these churches out of a hundred knows of the existence of such a creed or can give any idea of its content. The churches thus far have failed to promulgate it through their pulpits and Sunday Schools.

${ }^{1}$ Perhaps the best discussion of public opinion from the standpoint of sociology is to be found in Cooley's Social Organization, especially Chapter XII. See also Giddings' Principles of Sociology, p. 139 f., and the author's Introduction to Social Psychology, p. $155 \mathrm{f}$. 
opinion, we have said, is the chief force in civilized society which lies back of almost all laws and institutions; ${ }^{1}$ but laws and institutions mould very largely the character of individuals. This is particularly true if we include in institutions the "mores," that is, the moral standards of the people. According to practically all sociologists the mores are the immediate determiners of the conduct of masses of men. It is absurd to think that we can have a Christian society so long as we have pagan mores, as we have seen we largely have in Western civilization. ${ }^{2}$ The problem of creating Christian society is, then, essentially the problem of developing Christian mores. But the mores are the products of past public opinion; they can be remade and reshaped by the public opinion of the future, just as they were made by the public opinion of the past. There is no fatality nor finality about the mores, though people are prone to acquiesce in them as if there were.

Our civilization still halts between the ideal of a society based upon force and the ideal of a society based upon good will or Christian love. The mores of barbarism still so largely survive among us, we have seen,-in our industry, in our politics, in our personal relations-that it is with difficulty that men accept, hold to, and live out the Christian ideal of life. Such mores, we have seen, are the chief source of evil and maladjustment in our

1 That is, in a creative way, from the standpoint of control over change. Professor Mecklin distinguishes sharply. (Introduction to Social Ethics, Chapter IX) between public opinion and social or public conscience. Such distinction is, of course, justifiable; but it should not be overlooked that public opinion is the dynamic element in changing the social conscience. Effective public opinion creates social conscience; and if its formation can be safeguarded in the ways which we point out, its intelligence will be assured.

${ }^{2}$ See Chapter IV. 


\section{THE RECONSTRUCTION OF RELIGION}

present society, and they threaten to carry us back again completely to that pagan barbarism from which most of the nations of the world are but just emerging. They are the chief enemy of the church and Christianity. If we want a Christian world, we must have in the place of the mores of barbarism Christian mores, Christian institutions, Christian civilization, a Christian social environment in brief, in which the Christian life will come as easily and naturally to individuals as national loyalty and patriotism do now. But to make this Christian social environment, the Church must control the power which lies back of institutions and their changes, and that power is public opinion.

But let us now consider the nature of public opinion, for there are many misconceptions prevalent, and then let us see in detail how the church might undertake to form public opinion democratically and effectively upon all social problems. Public opinion does not imply absolute uniformity of opinion on the part of the members of a group, as is so often assumed. In large complex populations that would be impossible. There must be, of course, a certain core of agreement among the individuals of a group or at least among a majority, but no absolute uniformity of judgment is necessary. Public opinion is rather an organization, a co-ordination, of many separate individual judgments which all have a definite trend or direction. Thus a collective judgment is reached which we call "public opinion." To illustrate: no absolute uniformity of opinion regarding the evils of alcoholic beverages or regarding details of anti-liquor legislation has existed in the United States. There has been general agreement, however, as to the evils of the liquor traffic and of intemperance; and around this core of agreement 
it was possible to crystallize opinion in favor of the eighteenth amendment and, we hope, of its enforcement. Of course, no absolute uniformity of opinion regarding social matters can be expected to exist among members of the many branches of the Christian church. It should be possible, however, to find a core of agreement, in that all, or at least a majority, of church members may be presumed to want a Christian society, a society based upon good will and mutual service. Around this core of agreement, it should be possible to crystallize a public opinion in favor of definite Christian customs and institutions. These illustrations show that the formation and effective functioning of a Christian public opinion, while it would require unity in essentials, would leave liberty among Christians in non-essentials. This truth needs emphasis in view of the many divisions which exist in the Christan church.

From this it follows that the rule of public opinion is not necessarily the rule of the lowest mind or even of the average mind in the group which forms the opinion. On the contrary, if public opinion means no absolute uniformity of individual judgment, but rather the co-ordination of opinions in a definite direction, it may well represent the mature judgment of leaders and specialists who are in close touch with the public. Neither the church nor the world needs to fear the rule of public opinion if it is properly formed. The actual level which public opinion reaches will depend upon a variety of circumstances which we shall proceed to consider; but it is evident that it need not represent the level of the lowest mind in the group nor even of the mediocre mind.

But before we proceed we must warn against confusing public opinion with public sentiment and popular 


\section{THE RECONSTRUCTION OF RELIGION}

emotion. Much injury has been done to democracy by confusing the rule of public opinion with the rule of public sentiment or popular emotion. Public opinion is a more or less rational collective judgment formed by the action and reaction of many individual judgments. It differs radically, therefore, from popular emotion, which depends for its formation upon the contagion of feeling, and from public sentiment, which is usually the mass of feelings associated with the well-established habits of a group. Rather, public opinion is concerned with social changes, with making new social adjustments. Its strength and durability consists in its degree of rationality and in the fact that it is formed through deliberate and open discussion. Public sentiment and popular emotion may exist without public discussion, but not true public opinion. Public sentiment is usually conservative, popular emotion frequently destructive and reactionary; while public opinion, because it is formed by rational discussion, is constructive and creative. The evangelism of the church, therefore, to create a Christian world should beware of stirring up popular emotion, and should confine itself to the creation of true public opinion in support of the Christian program. Emotion should be appealed to, if at all, only after a rational public opinion has been created; for the work of emotion should be to intensify, but not to guide, action.

What then are the principles which should guide the church in its work of forming public opinion democratically and effectively? First of all, rational, effective public opinion must be formed under conditions of freedom. It is only free and open public discussion which is competent to form true public opinion, we have seen; otherwise the product will be the opinion of some minor 
group or some special interest. Moreover, in proportion as public opinion is formed under conditions of freedom, in that proportion will public opinion reach the highest degree of rationality; for only under conditions of freedom can all the facts be brought to light, ideas compared, and judgments tested. Truth under such conditions will have the best chance to prevail, and public opinion will be powerful, because there will be general confidence in its rationality. The church should lead in such public discussion in all questions where moral issues are involved. The church has every interest, therefore, in maintaining free speech, and a free press-within the limits, of course, of courtesy, decency and truth.

The second principle which should guide the church in its efforts to form effective public opinion is that public opinion must be formed under conditions of obvious disinterestedness. If the work of the church for a Christian social order is to be effective it must be disinterested; that is, it should have in it no selfish motive. The church's sole interest should be in the good of humanity. The propaganda of revolutionary radicals, even though it is lacking in intelligence, often succeeds because of its disinterestedness. The temperance movement succeeded best when it learned to avoid partisanship and exaggeration, 1 and to work simply for social welfare. These illustrations clearly show that if the church wants dominion over the moral opinion of mankind, she must forget self-interest absolutely, and seek only the redemption of humanity. All denominational differences must be forgotten in devotion to this common unselfish end. Once the propaganda of the church did practically rule Western civilization; but as the church used its great influence for selfish and narrow ends, stifling thought and repressing social, political, 


\section{THE RECONSTRUCTION OF RELIGION}

and religious progress, it lost its influence. Even yet men look back with horror upon the period of the church's dominance in the past and with misgiving upon the church's influence in the present. But if the church, in its efforts to guide and control public opinion, will keep public discussion free and open, if moreover it will be disinterested in its leadership, and if finally it be intelligent, there will be no need to fear the leadership of the church.

The third quality needed by the church, then, if it is to guide public opinion democratically and effectively, is intelligence. Only as public opinion is formed with proper appreciation of expert knowledge and of intelligent leadership, can it develop the highest degree of rationality and power. The temperance movement, for example, developed its full power only when it allied itself with science, when it sought and diffused the fullest scientific knowledge regarding the effects of alcohol.

This means that if the church is to form public opinion effectively regarding social conditions, it must have a fuller appreciation of social science. Social intelligence is indispensable for the success of Christian ideals, and therefore the social sciences are the natural allies of the church in its work of building a Christian society. They will furnish more material for the effective guidance of public opinion in a Christian direction than even the Bible itself. If the ministry of the church is to undertake the function of social leadership, it should be trained even more in sociology than in theology. "The minister,"

${ }^{1}$ Says Bishop F. J. MeConnell (Journal of Religion, Vol. I, p. 194): "The theological schools more than any other agencies have the responsibility for the change of emphasis which we need. How many of us who left the theological school a quarter of a century ago had any hard training in the social sciences?" He concludes that theological faculties need experts on social reconstruction. 
says Professor Coe, "must be a critic of social organization and process, and particularly of the human product. ... To what extent does this social order aim to produce and succeed in producing the best sort of men and women ?" 1 The Christian movement will develop its full power only when it allies itself with social science and when it seeks and diffuses the fullest scientific knowledge of social conditions. It is regrettable, therefore, that the church as a whole has as yet so little faith in the social sciences; for scientific social knowledge could help it, more than wealth or temporal power, to make this world Christian. The church needs conversion to modern science almost as much as the world needs conversion to Christianity.

To be sure, there is much so-called science to-day, even among social scientists, which lacks common sense, is materialistic, and even anti-Christian; but so far as this is not merely incidental to the undeveloped condition of the social sciences, it is largely due to the lack of interest of the churches in these sciences. The temperance movement, we have seen, will win out through its alliance with science. So it will be with practically every phase of the Christian movement if it seeks alliance and guidance from science. If the church is to create public opinion upon social problems its first duty is to be intelligent; and it cannot be intelligent without adequate scientific knowledge of the facts and principles of human living together. The church has vital need of the social sciences. It needs more knowledge of the facts and forces which make or mar the lives of men; and there can be no doubt that these facts and forces are mainly social. On the other hand, the social sciences, though they exist to make a better human world, lag behind in their development because the

${ }^{1}$ Journal of Religion, January, 1921, p. 27. 


\section{THE RECONSTRUCTION OF RELIGION}

church demands so little from them and gives them so little support. The social sciences need the help of the church; and the church needs the help of the social sciences. There should be an alliance, therefore, between these two. A practical step in this direction would be the establishment of chairs of sociology, politics, and economics in all schools of religion and in all Christian colleges. Then the church might become socially intelligent and marshal its hosts effectively. for the redemption of the world.

What methods, then, may the church legitimately employ to form and guide public opinion? This question we have already answered by implication, but a few concrete measures may be specified. First of all, there is oral discussion. Church members should realize that one of the first duties of the Christian life is to create public opinion and public conscience on social matters. This they can do by discussing these matters with friends and neighbors in the light of Christian principles. Habits and opportunities favoring oral discussion are falling into disuse, however, in modern society. The church might overcome this tendency to a certain extent by organizing "discussion groups" and "open forums" for the discussion of social matters. Sermonizing by ministers on social questions, no matter how excellent, is by itself inadequate, if there is not discussion of these sermons by the church members; for effective public opinion is always the co-operative product of the interaction of many individual minds.

A second agency, which the church should employ to form and guide public opinion is the press, which in our civilization has become the chief factor in the making of 
public opinion. Here indirect action will probably be most effective. If those church members connected with the press as managers or editors did their full duty in creating Christian public opinion, our civilization would soon become Christian. They are not wholly to blame, however, for failing to carry Christianity into their business; for the church thus far has failed to insist that a supreme duty of its lay members is to create public conscience regarding social matters. The church should insist, therefore, that editors and managers of the press have in their business the greatest opportunity for Christian service and therefore the utmost responsibility.

Direct methods of working through the press to reach public opinion should, of course, also be employed by the church. The most powerful agency is undoubtedly the daily and weekly secular newspapers; but the religious periodical might be made scarcely second in importance. Telling articles along every line of the work of the church and of social conditions might bring Christian responsibility home to church members in ways which would be effective for the creation of Christian public opinion and public conscience.

The church, too, should not neglect to advertise properly its activities and movements. Psychologically, the whole matter of controlling and guiding public opinion may be said to be a matter of effective advertising. The most righteous program of the ages cannot succeed, we should remember, unless in some way it can be made to secure the serious and thoughtful attention of the mass of men. Sensational methods, of course, discredit themselves and bring reproach upon the Christian cause; but the church has been too timid in employing proper methods to champion the Christian program and to bring it to the attention of the public. 


\section{THE RECONSTRUCTION OF RELIGION}

We come again to the teaching work of the church as the thing which is fundamental both in the creation of individual Christian character and in the creation of Christian public opinion. The education of the young, as we have seen, must be peculiarly the method of the church. In the long run, the education of the young is also the most effective method of controlling public opinion. The overwhelming American opinion against the liquor traffic was undoubtedly largely the result of introducing temperance instruction into the public schools. The church should use its influence to get adequate instruction on all social matters introduced into our public schools. It should insist that public education is for the sake of creating good citizens. If it cannot yet succeed in getting instruction in the public schools on social matters directly connected with the consideration of Christian principles, it can at least do so in its own schools and study classes. In the church's Sunday school especially there should be instruction given regarding social matters in direct and vital connection with Christian principles; but the average Sunday school will have to be remodelled before this can be done effectively. Says one of the leaders of religious education in the United States: ${ }^{2}$ "We find that the prevailing method of religious education in America cannot claim the name of system. It has no intelligent curriculum. It uses much unsuitable material, while it neglects a mine of wealth. It neglects the present condition of the world, the religious movements of our day, and the duties of the hour. It neglects the revelation of God in the Universe as disclosed by modern science. It neglects what social science has discovered in the ways of doing good to men. It imparts no sane method of ascertaining truth and deciding duty. The

${ }^{2}$ Dr. W. G. Ballantine. 
only method it uses is a capricious exegesis of ancient texts."

While many of the best Sunday schools in our cities have gotten to a much higher plane, it is still true that the average Sunday school too often teaches the Bible or Christian principles abstractly with little or nothing said about the concrete social situations in our civilization. This is probably the reason why the religion of so many church members fails to function when they come into practical contact with the labor problem, the negro problem, the divorce problem or some other concrete social situation. Something more than the Bible and Christian principles should be taught in our Sunday schools; and that is knowledge of actual social conditions in comparison with Christian ideals. There is no good reason why good books on social and economic problems, written with a Christian background, should not be used in our Sunday schools along with the Bible. ${ }^{1}$ A text book in sociology, with a Christian viewpoint, is no more out of place in a Sunday school room than a book in Christian theology. The advanced classes should, indeed, be studying such books in connection with a study of the Gospels. The vital study of Christian ideals in relation to real life could do more to Christianize public opinion than probably any other means. If the Sunday school was thus vitalized through study of the concrete problems of Christian living, there would probably be no lack of interest in it on the part of either children or adults.

1 Says Professor Coe (A Social Theory of Religious Education, p. 315): "The spirit of Jesus is so forward looking, so creative, so inexhaustible, that the Bible cannot possibly be a sufficient text-book of Christian Living. To tie religious education down to it, as dogmatism desires to do, would make us like those who are ever learning, but never able to come to the truth-ever learning to love, but ever permitting the social order to defeat love." 


\section{THE RECONSTRUCTION OF RELIGION}

To sum up; if the church is to create a Christian world, it must control in larger measure public opinion which is the ruling force of our time and the real sovereign of democracy. But to do this, the whole method and machinery of the Christian church must be modernized. The church must make a larger use of scientific sociological and psychological knowledge of every sort. The church must be profoundly interested in promoting and diffusing social knowledge. The world is perishing for lack of knowledge of the way in which human beings should live together. The church holds one key to this knowledge, the social ideals of Jesus, and the social sciences the other. In the formation of an effective public opinion to create a Christian world, the church must use not only the key of Christian ideals, but also the key of scientific social knowledge.

Thus the church might permeate institutions as well as individuals with the Christian spirit and create a Christian social environment, in which, as we have said, the Christian life would seem as "natural" as the life of greed and selfishness now seems. Thus the Christian spirit might permeate and gradually transform, in the ways we have already indicated, the family life, the political life, the life of pleasure, and even the economic life. The radical program of social Christianity now stands revealed. That it is more utopian and revolutionary than the program of some revolutionists cannot be denied; for it seeks to base human society upon love and reason and would fearlessly follow these in building a new social order. That it is a program which will be unacceptable to those who wish to live a self-seeking life, to those who are unwilling to surrender self in service, also cannot be denied. How then is it practicable? What motives are powerful enough to put such a program into 
practice? The new social Christianity, it is said, will not work, because it lacks strong motives. The old theological Christianity appealed to men's fear and self-interestthe strongest, it is claimed, of human motives. If the new social Christianity is the religion of Jesus, then it is a religion which will not work.

The reply is, that self-seeking impulses are not the strongest human motives, even though they are most in evidence in our present social system. Self has never been able to inspire the devotion which unselfish ends have called forth. All the higher religions, and not simply Christianity, attest that devotion to an ideal is potentially the strongest of human motives. In social Christianity this devotion naturally divides itself into devotion to its leader and devotion to the cause. "The heart of all religion," says a Japanese Buddhist, "is the faith that binds the soul to its Lord." So in Christianity, belief in, love of, and loyalty to Jesus is the primary motive in the religious life. That has been the foundation of all of its forms, and so must remain as long as the name itself endures. The church must continue to emphasize this motive. Personal leadership and personal loyalty are at the heart of every great movement in human society. But beyond this personal loyalty to Jesus, social Christianity sees the loyalty to the cause which he represents. The supreme motive in Jesus himself was the love of humanity-it was redeeming love-and this must also be the supreme motive of every genuine follower of his. This love of humanity must be the moving impulse of any religion which seeks the redemption of the world. It is clearly the impulse of Jesus himself. The church must throw its supreme emphasis, then, upon the love of, and the loyalty to, the Great Community-humanity. This 


\section{THE RECONSTRUCTION OF RELIGION}

means loyalty to all truth, to all right, to all betterment, and so to God himself. This is the motive to which the church must make appeal in its work of creating a public conscience which shall make possible a Christian world. It is no impracticable motive. It is the motive which has inspired the greatest and best of our race, from Jesus down to the present; it is the motive of every great move ment to which we can give our whole-hearted assent. It is this motive, which is growing ever larger and more powerful with the passing years, upon which social religion would build its idealistic faith. The Christian church undertakes no impossible task. It summons men to devotion to no impracticable ideal. A Christian world is not only practicable; in the long run it will be found that no other sort is practicable. 


\section{APPENDIX}

"THE SOCIAL CREED OF THE OHURCHES"

THE following statement was adopted by the Federal Council of Churches of Christ in America in 1908, and has since been adopted by the leading Protestant denominations, the Y. M. C. A., and the Y. W. C. A.

This creed reads as follows:

(1) Equal rights and justice for all men and in all stations of life.

(2) Protection of the family by the single standard of purity, uniform divorce laws, proper regulation of marriage, proper housing.

(3) The fullest possible development of every child, especially by the provision of education and recreation.

(4) Abolition of child labor.

(5) Such regulation of the conditions of toil for women as shall safeguard the physical and moral health of the community.

(6) Abatement and prevention of poverty.

(7) Protection of the individual and society from the social, economic, and moral waste of the liquor traffic.

(8) Conservation of health.

(9) Protection of the worker from dangerous machinery, occupational diseases and mortality.

(10) The right of all men to the opportunity for selfmaintenance, for safeguarding this right against encroachments of every kind, for the protection 
of workers from the hardships of enforced unemployment.

(11) The right of employees and employers alike to organize, and for adequate means of conciliation and arbitration in industrial disputes.

(12) Suitable provision for the old age of the workers, and for those incapacitated by injury.

(13) Release from employment one day in seven.

(14) Gradual and reasonable reduction of hours of labor to the lowest practicable point, and for that degree of leisure for all which is a condition of the highest human life.

(15) A living wage as the minimum in every industry, and for the highest wage that each industry can afford.

(16) A new emphasis upon the application of Christian principles to the acquisition and use of property, and for the most equitable division of the product of industry that can ultimately be devised.

At the meeting of the Federal Council in 1919 the following four amendments were added to the above "creed."

Facing the social issues involved in reconstruction:

RESOLVED: That we affirm as Christian Churches,

(1) That the teachings of Jesus are those of essential democracy and express themselves through brotherhood and the co-operation of all groups.

$\rightarrow$ We deplore class struggle, and declare against all class dominion, whether of capital or labor. Sympathizing with labor's desire for a better day and an equitable share in the profits and management of industry, we stand for orderly and progressive social reconstruction instead of revolution by violence. 
(2) That an ordered and constructive democracy in industry is as necessary as political democracy, and that collective bargaining and the sharing of shop control and management are inevitable steps in its attainment.

(3) That the first charge upon industry should be that of a wage sufficient to support an American standard of living. To that end we advocate the guarantee of a minimum wage, the control of unemployment through government labor exchanges, public works, land settlement, social insurance and experimentation in profit sharing and cooperative ownership.

(4) We recognize that women played no small part in the winning of the war. We believe that they should have full political and economic equality with equal pay for equal work, and a maximum eight-hour day. We declare for the abolition of night work by women, and the abolition of child labor; and for the provision of adequate safeguards to insure the moral as well as the physical health of the mothers and children of the race.

At the meeting of the Federal Council in Chicago, December 16, 1921, the following declaration of International Ideals was adopted:

(1) We believe that nations no less than individuals are subject to God's immutable moral laws.

(2) We believe that nations achieve true welfare, greatness, and honor only through just dealing and unselfish service.

(3) We believe that nations that regard themselves as Christian have special international obligations.

(4) We believe that the spirit of Christian brother- 
liness can remove every unjust barrier of trade, color, creed, and race.

(5) We believe that Christian patriotism demands the practice of good will between nations.

(6) We believe that international policies should secure equal justice for all races.

(7) We believe that all nations should associate themselves permanently for world peace and good will.

(8) We believe in international law, and in the universal use of international courts of justice and boards of arbitration.

(9) We believe in a sweeping reduction of armaments by all nations.

(10) We believe in a warless world, and dedicate ourselves to its achievement.

Essentially similar statements have been promulgated by the Administrative Committee of the National Catholic War Council in America and by the Central Conference of American Rabbis. A critical summary of the various social programs of different religious bodies will be found in Ward, The New Social Order, Chapter XI. 


\section{INDEX}

\section{$\mathbf{A}$}

Abnormal classes, help of, 167; marriage of, 200, 201.

Abstraction, power of, 40, 50 .

Acquired character, 63, 189, 190, $192,266$.

Adams, Henry, cited, 73, 111.

Adaptation, 8, 9, 37, 38, 41, 133, 155; religion as an organ of, $37,38,41,55,133,155$.

Addams, Jane, cited, 267, 268, 270.

Adler, Felix, cited, 207.

Advertising, church, 301 .

Agnosticism, 1, 22, 25, 31, 40, $124,125,127$.

Altruism, 9, 67, 106, 168-178, 181, 190, 191, 199, 207.

Ames, E. S., cited, 42, 57, 58, 60, 160.

American Indians, 49, 50.

American religion, 13, 25, 115, 121-124, 287.

American social conditions, 21, $22,94,102,106,112,115,194$, $214,215,287$.

Amusements, social, 102, 264279.

Ancestor worship, 24, 48, 52.

Animatism, 49 , note.

Animism, 24, 45, 46, 48-51.

Anthropology, x, xii, 34, 49, 61, $70,71,76,140,145,220,259$.

Anthropomorphism, 52, 140.

Applied social science, ix, $x i, 161$.

Archæology, 71, 80.

Aristotle, cited, 97, 164.

Art, 52, 98, 109, 117, 276, 277.

Asceticism, 165, 198, 208, 270, $271,278,279$; definition of, 270.

Atheism, 7, 25, 46, 250.
Attitudes, social, 40, 46, 161-186, $189,213,226$; negative, 46, $111,112,124$; religious, 26,40 , $47,120,126,154,155,211$.

Authority, external, 100, 101, 251.

\section{B}

Bacon, B. W., cited, 88 .

Bahaism, 68.

Ballantine, W. G., cited, 302.

Barbarism, definition of, 71,97 ; traditions of, in modern society, $72,73,86,97,110,293$; recrudescence of, $75,95,98,100$, $101,102,116,117,193,212$, 244, 266, 294.

Bargy, Henry, cited, 121.

Bartlet, J. V., cited, 221.

Barton, G. A., cited, 47.

Batten, S. Z., cited, 290.

Behavior, human, 34, 37, 60, 149, $182,266,293,305$.

Beliefs, religious, 4, 11, 13, 14, $16,22,34-69,104,130,132$.

Bergson, H., 10.

Bible, place of, in Christianity, xii, 152-154; proper use of, 88, 153,154 ; criticism of, 101,154 .

Biological elements in human life, 111, 163, 198-203, 265.

Bismarck, 103.

Boas, F., cited, 49.

Bowne, Borden P., cited, 133.

Branford, Victor, cited, vii.

Brightman, E. S., cited, 132.

Brown, W. Adams, cited, 113.

Buddhism, 1, 46, 68, 146, 150.

Bury, J. B., cited, 36.

Butler, Samuel, 108.

Business, anti-Christian, 21, 102$107,114$. 
Caird, Edward, cited, 47, 125.

Capitalism, 105, 217, 227.

Carpenter, Edward, cited, 13, 45, 47, 71, 198, 262.

Carver, T. N., cited, 162, 216, 236.

Case, S. J., cited, 70, 77, 82, 146.

Catholic church, 284, 285, 310.

Channing, W. E., cited, 122.

Character, individual, how formed, 104, 189, 190, 210, 243, 264,293 ; importance of, 253 , $287,291$.

Charity, 28, 167.

Chastity, 199, 203.

Child, sociological significance of, 204-206; and Christianity, 207, 208.

Chinese, 53.

Christ, see Jesus.

Christian democracy, 263.

Christian ideals, see Ideals.

Christian movement, the, 70, 77, $82,83,299$.

Christianity, definition, 1, 70; origin of, $70-82$; social signifcance of, 70-92; social character of, 76.81, 84, 91, 137, 181187 ; Greek element in, 80 ; relation to Judaism, $69,77,80$, 87 ; to Oriental religions, 80 ; humanitarian nature of, 76-92, 183-187; historical, 39, 85-89, 186 ; in Western civilization, $83-89,90,93,99,108,115,118$; positive, 119-160; essentials of, 78-84, 181-187; and the family, $194,207-209$; and industry, 211-213, 241, 242; and politics, $245,262,263$; and amusements, $267,278,279$; revolutionary character of, 77, 79, 130, 304 .

Church, present condition of, ix, $1,2,113,282$; opportunity of, 280-306; union of, 283-285; membership, 159, 286; Paganism in, 86, 92, 98, 114, 286; and religion of Jesus, 13, 85-88, $98,282,286$; social necessity of, 131, 280, 281; and public opinion, 290-304 ; and religious education, 287-289, 302, 303 ; social function of, 131, 280 . 290.

Churches, Federal Council of, in America, 291, 307; social creed of, $211,291,307$.

Civilization, definition, 71, 72; nature of, 34, 61-63, 71-74, 107; relation to religion, 34 , $54-64,75$; reversions in, 16 , $73,95,117$; problem of our, 93 , 100 ; present condition, 93-118, 193,293 ; reconstruction of, 3 , 93, 291; Christian, 93, 117, $118,290-304$.

Class strife, 106, 107, 171-173, $257,258$.

Classes, social relations of, 106 , 171,222 ; social necessity of, 221, 222.

Codrington, R. H., cited, 49.

Coe, G. A., cited, xiii, 10, 114, $152,155,161,287,298,303$.

Coit, S., cited, viii.

Communal character of religion, $36,43,47,280$.

Communism, 219, 220, 225-227.

Community life, 129, 161, 167, $169,171,182,189,274,305$.

Comparative religion, 48 .

Comte, Auguste, cited, 20, 29, 44, $63,119,120,121,122,125$, $132,140,141,158,171$.

Conflict, necessity of minimizing, $91,117,171,216,246,256$, 258; between classes, 16, 67, $106,171,213,216,230,246$, 256-258; between nations, 16, $103,172,246,259-261$; between races, $16,67,172,259$; between Christianity and paganism, 18, $75,76,79,86,98-101,117,118$.

Conflicting ideals of our civilization, viii, 11-16, 75, 98-118; 293.

Confusion of the present, 11-17, $99,100$.

Conklin, E. G., cited, 2, 24, 46, $60,100,134,159$. 
Consciousness, religious, 48-55, $125,126,132,133,137$.

Consciousness of kind, 72, 76, 169.

Consecration, in religion, 44, 47, $117,159,166,203,286$.

Conservation of social values, 24, $38,60,65,114,193$.

Conservative tendencies of religion, 52, 55-65.

Consumption of wealth, 239, 240.

Control, social, religion as a means of, $12,42,47,50,52,55$, $56-63,87,101,203,268,270$, 291 ; need of more, 29, 43, 64, 291, 292.

Conversion, religious, 289.

Cooley, C. H., cited, $44,81,169$, $188,191,192,250,262,266$, 292.

Co-operation, maximization of, 91 , 163-169, 171, 173, 231, 232; between classes, 167, 222, 225, 230-235; among churches, 121, 131, 283-285.

Creative evolution, 136, 138.

Crime, 170, 175, 190.

Crises, function of religion in, 37, $38,41,42,43,76$.

Criticism, social function of, 3 ; destructive, 95, 101, 103, 108, $113,154$.

Criticism, higher, 145, 146, 153, 154.

Cultural evolution, 16, 61, 70-75; function of religion in, 55-64, 75-77.

Culture, definition, 12, 71; relation of religion to, $34,54-64$, 75,76 ; see also Reversions in culture.

Custom, definition, 61 ; relation of religion to, $34,35,55,61$ 63.

\section{D}

Darwin, Charles, 90, 188.

Deism, 25.

Democracy, origin of, 81, 248; in social life, $247,252-259$; in in- dustry, 232-234, 258; in politics, 249, 251-263; and Christianity, $71,81,248,262,263$; and religion, viii, $2,248-251$, 257, 262.

"Democracy of God," 161.

Denominations, relations of, 283 , 297.

Determinism, economic, 210; mechanistic, 111.

Dickinson, G. Lowes, cited, vii.

Discipline, social, see Morale.

Discussion, public, 254, 296-298, 300.

Distribution of wealth, 214-216, 222, 223, 227-229, 236, 239.

Divorce, 21, 102, 206, 208.

Dogma, theological, 39, 121, 126, 142.

Doubt, 14, 30, 120.

Durkheim, Émile, cited, 27, 34, $37,51,52$.

\section{$\mathbf{E}$}

Ecclesiasticism, 29, 39, 83, 120.

Economic conditions, 11, 86, 104, 210-242; and Christianity, 86, 105, 212, 217, 241, 242.

Economic determinism, 210.

Economics, 163, 164, 210, 212, $214,219,221,223,241$.

Education, social, 202, 253, 254, $265,269,274,302$; see also $\mathrm{Re}$ ligious education.

Educational conditions, 107, 116, 234, 240, 254, 265, 274, 288.

Educational function of the church, 287-289, 302-304.

Egoism, 19, 67, 75, 96, 99, 174, $179,180,191,220$; see also Group egoism.

Egoistic theory of human nature, $96,105,179,212,268,305$.

Ellwood, C. A., cited, xii, 3, 9, 11, $14,16,25,38,73,74,169,173$, $190,238,290,292$.

Ely, R. T., cited, 162, 221.

Emery, H. C., cited, 91.

Emotional element in religion, 
viii, $7,8,40,42,75,136,152$, $168,170,296,305$.

Emotionalism, 152, 289, 296.

Encloe, H. G., cited, 151, 284.

Enthusiasm of humanity, 84, 218, 259.

Environment, influence of, 87, $190,210,264$; social, 87, 190, 210, 293, 304; Christian, 294, 304.

Epicureans, 97.

Equality, 233, 247, 248, 250; of opportunity, 223, 233-236, 239, 247.

Eschatological view of Jesus' teaching, 83, 84, 150, 154.

Eskimo, communism of, 220.

Ethical Religion, 26, 54, 55, 64, $66,77,128$.

Ethics and religion, 55, 56, 62, $64,128,161,162$; see Humanitarian religion.

Eucken, R., cited, 46, 82.

Eugenics and religion, 200-203.

Europe, religious condition of, $13,112,115$.

Evil, problem of, 68, 134, 135, $143,156$.

Evolution, social, 24, 35, 54, 71$76,81,92,138$; cultural, 16 , $61,70-75$; religious, $24-27,47-$ $54,69,75,81,83$.

Exchange of services, 163-167, 176,213 ; basis of social life, $38,163,176$.

Experience, as a basis of religion, $3,8,30,58,119,120$.

\section{F}

Faith, xii, 27, 30, 31, 46, 60, 130, $135,142,146,161,305$.

Family, the importance of, as a primary group, 21, 188-193; source of religious ideals, 66 , $81,191,193$; present condition, $21,105,108,193-203$; and social religion, 188-209.

Fear, 22, 31, 172, 216, 244, 246, 305.
Feeling element in religion, see Emotional element.

Fellowship, human, 79, 138, 143, $163,170-177,230$.

Figgis, J. N., cited, 18, 19.

Fitch, A. P., cited, 1, 8, 87.

Follett, Mary P., cited, 248, 291.

Food, importance of, 164, 210.

Force, limits of use, 153, 172, $173,174,175,243,259-261$.

Forgiveness, 174-176, 209.

Fraternity, 78, 118, 121, 125, 167, $168-173,181,184,192,216,232$, $248,250,255,262$.

Frazer, J. G., cited, 51.

Free society, 28, 112, 157, 247263.

Freedom of thought and speech, 157, 247, 254, 255, 296-298, 300.

French Revolution, 102.

Friday, David, cited, 215.

Function of religion, $34-47$; 5566 ; of early religion, $27,49-$ 52 ; in the life of the individual, $27,37,38,40,41,44$; in social control, 42, 55-65; social progress, 66, 67, 74-76.

Future life, see Immortality.

\section{G}

Galton, Francis, cited, 202.

Gautama Buddha, 1, 146, 150, 172.

Geddes, P., cited, vii.

German civilization, 21, 84, 104, $109,112,116,245$.

German higher criticism, 83, 84, 154.

German theology, 83, 84.

Germany, in the Great War, 21, $24,103,112$; rehabilitation of, 116 , note.

Geographic influences, 80, 103.

Giddings, F. H., cited, 169, 292.

Glover. T. R.. cited, 86, 146.

God, definition, 54, 136, 137 ;

Christian conception of, $\mathbf{8 4}$, 137, 138-140; subjective con- 
ception of, 125, 132, 133; and nature, 133-137; and humanity, 132, 137-140; philosophical necessity of, $26,135,136$; origin of idea, $50,52,53,54$, 57.

Goldenweiser, A. A., cited, 51 .

Good will, social importance of, ix, 29, 60, 62, 170-175, 254, 261; between classes, $172,255,257$; between nations, $172,246,248$, 261 ; and religion, ix, 29, 60, 62, 83, 168-176, 261 ; Christíanity, a religion of, 78,83 , $92,118,159,168,181$.

Gospels, Christianity of, xii, $93,118,143,145,147,153$, 184.

Government and religion, 28, 34, 65, 104, 243-263.

Great Britain, 103, 116.

Greece, ancient, civilization, 96 ; philosophy, 97, 110; influence on modern world, 98, 100.

Greek Catholic Church, 284.

Greek ideals of life, 96, 97, 110. Group, importance of, 42, 60, 66, $81,129,144,188,189,243,290$; organization, $243,246,247$, 252.

Group egoism, 95, 171, 172, 256258.

Group morality, 72, 77, 83.

Group salvation, $80,83,144,161$, 184.

Groups, primary, $21,66,81,188$ 192, 248.

Guyan, J. M., cited, 25.

\section{H}

Habit, influence of, $14,15,34,60$, $61,75,266$; and civilization, $34,61,64,189,267$.

Hall, G. Stanley, cited, 132, 155. Harrison, Frederic, cited, vii, xviii.

Harrison, Jane E., cited, 25, 42, 47.

Hart, J. K., cited, 80, 81.
Hastings' Encyclopedia of Religion and Ethics, 33, 52, 184.

Hatred, 170, 172, 174, 216.

Haydon, A. E., cited, 132.

Hayes, E. C., cited, 86, 108.

Health, 200, 235, 265, 272, 287.

Hebrews, see Jews.

Hedonistic ethics, 14, 37, 38, $114,194,267,269$.

Henotheism, 23, 25, 26, 48, 53.

Heredity, control of, 200-202.

Hero worship, 52.

Historical Christianity, 39, 85$89,186,270$.

Historical influences, 76, 81, 8589.

History, human, nature of, 16, $73,95$.

History of religion, 24, 48-54, 68, 69.

Hobhouse, L. T., cited, xii, 3, 4, $6,8,9,10,22,27,67,99,116$, 136, 139, 168, 221, 225, 248.

Hocking, W. E., cited, 4, 114, 186.

Holmes, J. H., cited, 93, 137.

Hostility, minimizing, 91, 172, $246,248,258$.

Hubbard, A. J., cited, 35.

Hudson, J. W., cited, 14, 102.

Humanitarianism, definition, 67, 68; relation to Christianity, $76,77,83,84,121-124,160$, 208 ; in the nineteenth century, $114,116$.

Humanitarian ethics, 43, 67, 77, $80,81,99,100,116,160,176$, $180,211,251,272$.

Humanitarian religion, $43,67,68$, $69,77,80,87,89,120-160,170$, $172,181,208,218,246,250$, $261,272,305$; see also $\mathrm{Hu}-$ manity, religion of.

Humanity, definition, 67; unity of ethical valuations, 43, 44, 180,183 ; religion of, 67,89 , $120,121,124,160,172,180$.

Human nature, definition, 266; influence of, $15,100,253,266$, 268 ; theories of, $96,105,169$, $174,179,212,305$. 


\section{I}

Idealism, social, 66, 81, 126, 192, $257,262,281$; relation to religion, $42,54,66,77,83,193$, 281.

Ideals, social function of, 61, 74, $89,90,104$; conflict of, 11,14 , $75,85,98,99,100,101,117$; sources of, $21,66,81,188,191$.

Ideals, Christian, 18, 77-84, 99$103,108,115,117,118,125$, $128,130,153,155,185$.

Ideas, pattern, $61,66,74,98$, $173,191,248$.

Idolatry, 53.

Ignorance, sociological, 70,88 , 202.

Imitation, influence of, 60, 174 .

Immoralism, 96, 108, 243.

Immortality, belief in, 132, 140143 ; origin of idea, 51,58 ; necessity of idea, 58,142 ; personal, $142,143$.

Impulse in religion, $7,8,79$, note.

Impulses, animal, 15, 197, 198, $202,266,267,268,270,275$.

Income, 214, 229, 237; of people of United States, 214, 222, $223,240$.

Individual as a social factor, 17, $43,82,100,129,145$; value of, $77,82,129,145,166,167,180$, 183,287 ; relation of religion to, $27,29,34,36,40,41,44$, $62,129,131,166,183,287$.

Individualism in modern civilization, $19,87,88,101,102,110$, $113,129,131,193,194,198$, $207,208,212,224,244,255$, 267.

Industry, modern, and Christianity, 12, 21, 104-107, 195-197, 210-242.

Infinite, the, as God, 54, 133.

Inspiration, 10, 88.

Institutions, social, 14, 62, 64, $73,80,89,161,163,184,206$; Church as an, 39, 131, 280-305.

Intellectual element in religion, $3-11,31,38,40,75,127-152$,
$159,218,288,289,298,299$, 302-304.

Intellectualistic theories of religion, 4.

Intelligence and social progress, $3,7,24,74,88,170$; in religion, $3,7,31,64,75,92,114$, $148,218,298$; see also Reason and Social Science.

Interdependence, social, 12, 29, $38,163,171$; international, 12 , 171-173, 186, 246, 260.

International relations, 12,24 , $102,112,115,117,118,171$ $173,186,245,246,259-261$.

Intuition, 10, 11 .

Invention, $11,24,61,74$.

Irrationalism, 4, 7, 9, 15, 22.

\section{$\mathbf{J}$}

James, William, cited, 34, 37, 155.

Jastrow, Morris, cited, 284.

Japanese, 21, 115.

Jesus, religion of, $1,77,82,84$, 146 ; personality of, 82,147 149; founder of Christianity, $77,82,146$; historicity of, 145,146 ; as a social philosopher, 91,159 ; as a thinker, 148, note, 159; as Messiah, 146; as moral leader and savior of mankind, $82,91,92$, $143, \quad 147-152,181-186,207-$ $209,241,242,262,263,285$, 305.

Jewish ethics, 69, 81, 148.

Jewish opinion, modern, 123, 151, 284, 310.

Jewish synagogue and Christian church, 283, 284.

Jews, religious genius of, 69,80 , 81.

Judaism, 69, 77, 80; and Christianity, $77,80,81$.

Justice, social， 78, 83, 85, 95, $130,178,230,233,234,249$, 261 ; necessity of, 210,233 , 242,261 ; inadequacy of, 178. 


\section{K}

Kant, Immanuel, cited, 4, 8, 143. Kent, C. F., cited, 88 .

Kidd, Benjamin, cited, viii, 9. King, W. I., cited, 214, 222.

King, H. C., cited, 88.

Kingdom of God, definition, 78, 184; a social conception, 78, $84,129,161,182-185,263$; \& spiritual ideal, 129, 184.

Kinship, sentiment of, 52, 255.

\section{I}

Labor, modern condition of, 106, $213-216,236$; social worth of, 228,229 ; exploitation of, 106, 213, 216, 236; and Christianity, 229, 241, 242; creative, $228,229,237$.

Labor movement, 106, 107, 232, $235,307,308$.

Laissez-faire attitude, 255.

Law, social, $62,90,134,135,159$, 182.

Laws of nature, 134, 139, 182.

Le'adership, social, 75, 82, 149, $159,298,305$; religious, 82 , $113,149,276,282,290,305$; of Jesus, 82, 92, 149, 150, 151, $159,182,305$.

League of Nations, 172, 260.

Leuba, J. H., cited, 13, 25, 36, $47,50,114$.

Likemindedness, social value of, ix, 42, 59, 170, 174, 251, 254, $255,259,261$.

Literature, modern, 101, 107, 108.

Love, definition, 168,181 ; as an ethical principle, $78,84,92$, 168-176, 207; of humanity, 83, 84, 169-176, 183, 305; sacrificial, 172-178, 305; sexual, 197-207, 208; parental, 199, 204,208 ; as central principle of Christianity, 78, 83, 84, 92, $125,150,181,304,305$.

Loyalty, as an ethical principle, $39,42,60,131,143,149,182$, 183.
Luxury in modern life, 102, 165, 213, 236, 240, 241, 269.

Lyman, E. W., cited, 127, 136.

\section{M}

Machiavelli, Niccolo, 18, 19, 96, 97, 99, 104, 112, 244.

Machiavellian politics, 21, 29, $103,104,116,244$.

Magic, 22, 35, 36, 43.

Maladjustments, social, 167, 168, $194,195-197,202,213-216,234-$ 236, 249.

Man, religious nature of, 26, 29, $37,38,40,41,44,47,64,66$, 135; social nature of, 42,71 , $170,171$.

Mana, 45, 49, 56.

Manaism, 24, 49-51.

Manitou, 45, 49.

Marett, R. R., cited, 35, 47, 48, $49,55$.

Marriage, 22, 102, 193-208.

Marx, Karl, 106.

Material conditions, $86,164,165$, 195-197, 210-242.

Materialism, 46, 103, 111, 112, $126,136,140,165,196,225$, 250.

Materialistic standards, 14, 19, 101-103, 213, 214, 250; see also Materialism.

Mathews, Shailer, cited, 88.

McConnell, F. J., cited, 102, 298.

Mechanistic conceptions in science, $6,45,46,111,134,136$.

Mecklin, J. M., cited, 248, 293.

Metaphysics, 20, 29, 39, 111, 122, $126,127$.

Metaphysical problems, $x_{1} 26$, $111,124,126,132-143$.

Methodist movement, 76.

Methods, in science, 6, 30.

Militarism, effects of, 103, 104, $118,245,259-261$; origin of, $71,74,79$.

Millenarianism, 86.

Mind, social, 63, 252, 295, 296; see also Public opinion.

Minimum wage, 235. 
Missions, Christian, 186.

Mohammedanism, 68, 154.

Monogamy, 194-207.

Monotheism, 23, 25-27, 54.

Moral confidence, 26, 37, 41, 135.

Moral conflicts, see Conflict.

Moral ideals, see Ideals, social.

Moral order, see Order, moral.

Moral standards, 56, 62, 75, 102, $104,110,114$, see also Ideals; of Christianity, 78, 84, 91; of Paganism, 96, 99, 110.

Morale, social, $179,180,181,253$, 268-271.

Morality, idealistic, 64, 66, 67; customary, 55, 56, 60, 62 .

Morality and religion, 55, 56, $62,64,67,128,161,162$.

Mores, the, definition, 34,61 ; social power of, $34,75,103,293$; relation to religion, $34,55,56$, 62,79 ; re-making of, 75,292 , $293,294$.

Motivation, social, ix, 149, 156, $170,305,306$.

Mysticism, definition, 113, 114; danger of, $7,31,113,114$; place in religion, 4, 114, 123.

Mythological elements in religion, $59,120,139$.

\section{$\mathrm{N}$}

National egoism, 24, 104, 105, 171-173, 245, 256, 259-261.

National groups, 16, 24, 102-104, $115,118,172,243-263$.

National stage of religion, 23, 25, 53.

Natural laws, see Laws of Nature.

Natural science, 11, 111, 117, $119,136,139$; see also Science.

Nature, as related to God, 133, $134,137,138$; worship of, 53 , 133; see also Human nature.

Nature of civilization, see Civilization.

Nature of society, see Society.

Negative social attitudes, see Attitudes, negative.
Neighborhood group, the, 188.

Neo-Paganism, 17, 18-21, see Paganism.

Neo-Rationalism, see Rationalism.

Newton, J. F., cited, 108.

Nietzsche, Friedrich, 18, 19, 20, $33,96,97,99,109,110,112$, 262.

Normal life, 193, 195-197, 205, $211,234-236,244,247,265,279$. Novicow, J., cited, 38, 163.

Objectivity, demanded by religion, 125, 132, 133, 134.

Obligations, social, 56, 100, 203, 212, 224, 227, 241, 256.

Optimism and religion, 23, 41, 46.

Order, social, 55, 61, 65, 84, 115 ; and religion, $55,61-65$, $78,84,130,183-185$.

Order, moral, 134, 139, 156.

Organization, social, 61,243 ; of religious life, 131, 180-305; of good will, 175, 255, 260, 261.

Origin of religion, $34.55,66$.

\section{$\mathbf{P}$}

Paganism, definition, 96, 98; moral element in, 96, 99, 100; recrudescence of, $13,22,100$ 117; survival of, $95-117,244$; in politics, 103, 104, 244, 261; in business, 102-107, 114; in literature, 101, 107, 108; in philosophy, 99, 110; in science, 110-112; in the church, 86, 92, $98,114,286$.

Pantheism, 54.

Parental love, 199, 204, 208.

Parenthood, 204-208.

Passivity, social, 68, 130, 150.

Pathological social conditions, see Maladjustments, social.

Patríck, G. T. W., cited, viii.

Patriotism, 8, 179, 246.

Patten, W., cited, 111. 
'attern ideas, $61,74,98,173$, 191, 248.

aul, 88.

eace, social, $171,173,216,248$, 258 , 260; international, 118, $172,173,260,261$.

crsonality, as an ethical concept, 77, 143, 162, 181, 183, 252 ; as a social influence, 82 , $126,129,149,167,182$.

?essimism, $15,16,23,24,41,60$, 95.

?hilosophy, modern, 6, 110.

?hilosophy, social, $x$.

hysical elements in human life, $86,164,197-202,210-242,265$. ?lato, cited, $79,97$.

Play, function of, 264-279; necessity of, 265; degradation of, 266-269.

Pleasure, as an ethical end, 97, $99,100,101,102,110,114,193$, 267.

Pleasure, social, 99, 101, 264279.

Political corruption, 106, 245.

Political life, 105, 243-263.

Political organization, 243-263; importance of, 243,246 ; democratic form of, 247-263; and Christianity, 248, 250, 262, 263.

Politics, anti-Christian, 103, 104, $114,244,245$.

Polygamy, 22.

Polytheism, 53.

Positive, defined, 119.

Positive Christianity, 119-160.

Positive religion, 119-126, 127, $138,139$.

Positive science, $30,119,126,127$, 139.

Positivism, Comtean, 1, 46, 122, 132.

Power, as an ethical end, 97, 99, $100,101,104,110,173,244$, $246,267$.

Power, the will to, 2.

Poverty, moral effects of, 213, $214,216,235$; elimination of, 234-239, 240.
Pragmatism, 132.

Prayer, 154-157.

Press, freedom of, 254, 297; power of, 300,301 ; religious, 301.

Predatory traditions, $71,75,76$, 97, 98, 107, 110, 212.

Primitive man, 27, 71, 72; religion of, $27,49-53,55,56$.

Production, economic, 164, 222, 223, 230.

Progress, social, 24, 38, 61, 73, $74,95,167,170,190,229$; religion and, 64, 65-67, 75, 161 , 190; Christianity and, 75, 76, $78,83,138$.

Progressive religion, 30, 66, 126.

Profits, business for, 21, 29, 105.

Property, private, necessity of, $219,220,224$; abuses of, 102, 105, 212-214, 240; and Christianity, 211, 218, 227, 241; socialization of, $220,226$.

Prophetism, 290.

Prophets, the Jewish, 69, 77, 80. Protestant Reformation, 1, 76.

Protestant Christianity, 87, 113, 283-285, 286, 291.

Psychic nature of culture, 61-63, 74,107 ; of human society, vii, $11,38,61,74$.

Psychology, human, 33, 34, 41, $145,289,301$; see also $\mathrm{Be}$ havior, human.

Psychology of religion, 33, 40-42, 199.

Public conscience, 197, 276, 290293, 301.

Public discussion, see Discussion, public.

Public health, see Health.

Public opinion, definition, 252, 294,296 ; power of, 290,291 293; formation of, 252-254, 294-303; guidance of, 253, 290, 296-303.

Public ownership, 221, 231, 232.

Public sentiment, 296.

Public worship, see Worship.

Puritanism, the new, 271. 
Quakers, mysticism of, 113.

$\mathbf{R}$

Races, antagonism of, 16, 67, 171, $186,259,265$.

Racial egoism, 172, 250, 259.

Rational, defined, 3.

Rational religion, $3,5,7,8,11$, $30,31,35,55,63,92,119-160$.

Rationalism, the new, 4, 8, 9, 31, 136; eighteenth-century, 7,8 , 36.

Ravage, M. E., cited, 123.

Reason, definition, $5,8,9$; function of, 8, 9, 38; in religion, 4, $7,8,9,31,38,40$.

Reconciliation, doctrine of, 169, 170, 172, 173, 247, 283.

Reconstruction of religion, 3,15 , $33,70,93,119,161,210,243$, 264, 282.

Reconstruction, social, $3,15,93$, 213 ; of the family, 188-209; of industry, 210-242; of government, 243-263 ; of social amusements, 264-279; of the church, 280-305.

Recreation, social, necessity of, 265 ; as an element in social pleasures, 272, 274, 295; and the church, 275-277.

Redemption, social, 78, 144, 166168, 176, 242, 276, 290.

Redemptive religion, $78,84,87$, $127,129,144,145,158,167$, $181,183,186,242,276,290$.

Reformation of criminals, 170, 175.

Reformation, the New, 1.

Reformation, Protestant, 1, 76.

Religion, definition, 47, as an object of scientific study, $3,5,33$; reconstruction of, $3,92,120$ 264 ; in revolution, $1-31$; and science, $2-32,92,120-160$; and reason, $4,7-9,37,38,40$; origin of, $34-55,66$; cvolution of, $24,47-54,69,75$; primitive,
$27,49-53,55$; ethical, 26, 55, $64,66,77,128$; theistic, 25,54 , 136,137 ; function of, $34-47,55$. 66; psychology of, $33,40-42$, 199 ; revival of, viii, 75,282 ; social significance of, 33,37 , $38-69,75$; and social control, see Control; and social order, see Order; and social progress, see Progress; and social values, see Values; of Jesus, 1, 77, 82, 84; and Christianity, see Christianity; positive, 119-160; and the family, 188-209; and business, 210-242; and politics, 243-263; and amusements, 264279 ; see also Church.

Religious education, 269, 279, 287-289, 302-304.

Religious problem, the, 20, 26, 64.

Religious psychosis, 33, 36.

Religious Revolution, the, ix, 1 , $2,12,14,16,21,23,24,26,31$, 131, 304 .

Religious unity, 282-286.

Renaissance, the, 99, 102.

Renunciation, doctrine of, 68,85 , 99 , note.

Revivals of religion, 75 .

Reversions to barbarism, 75, 95 $117,193,212,244,266,294$; to paganism, $13,20,22,93$ 117 ; in culture, $15,16,21,22$, 23.

Revolutions, 15, 76, 77, 130, 217; see also Religious Revolution.

Rhys-Davids, cited, 172.

Rights, scientific view of, 223, $224,255,256$.

Ritual, 157.

Roman civilization, $79,80,96$ 102.

Rome, ethical influence of, 96102; political influence of, 96 , 97.

Ross, E. A., cited, 91, 264, 265.

Rowntree, B. S., cited, 230.

Royce, J., cited, 110.

Russell, Bertrand, cited, 13. 
Russia, 103, 118, 219; rehabilitation of, 116, note.

Sacred, the, defined, 49, 55; as primitive element in religion, 49.

Sacrifice, self, in religion, 38,42 , $43,60,63,67$; in Christianity, 78, 174-178, 181, 184, 209.

Sacrificial love, 174-178, 305.

Salvation, 37, 132, 143, 150, 156 ; social conception of, 143, 144 .

Santayana, George, cited, 95, 99.

Savagery, 27, 48, 55, 71-73.

Savage mind, the, 27, 49-51, 55.

Schleiter, F., cited, 48.

Schweitzer, A., cited, 83, 145, 150.

Science, definition, 6, 9; nature of, 6, 9; effects of, 2, 5, 12, 107,117 ; and reason, $6,37,40$; and religion, viii, $2-32,33-40$, $60,62,92,110-112$, 119-160; see also Social science.

Scientific method, 6, 30.

School, and religion, 288, 292, 303 ; and the church, 288, 302, 303.

Secularization, 28, 29.

Seeley, J. R., cited, 84.

Self-assertion, 99.

Self-consciousness, 40, 71 , note.

Self-culture, 99, 100, 187.

Self-development, 110, 180, 187.

Self-gratification, 100, 114, 193, 267.

Self-indulgence, 38, 114, 240, 267.

Self-interest, 102-107, 109, 169, $194,212,216,261$; inadequacy of, 169, 179, 180, 194.

Self-realization, social, 100.

Self-sacrifice, see Sacrifice.

Sellars, R. W., cited, 25, 41.

Service, human, as practical principle of Christianity, 77, $120,159,162,181,262$; as an ethical ideal, $38,43,60,77,83$, $100,105,120,125,163-168,170$, $171,176,181,191,209$; as an economic principle, 227-229.
Sex and religion, 199-203, 269, $271,275$.

Sex education, 201, 202.

Sexes, relations of, 198-203; Christian ideal of, 208, 209.

Shenton, Herbert N., cited, xiii, 238.

Shotwell, J. T., cited, 7.

Simkhovitch, V., cited, 76, 80, 91, 148, 149.

Sin, defined, 143 ; social conception of, 143, 144, 176.

Slavery, 73, 213.

Small, Albion W., cited, 163, 212, $220,229$.

Smith, G. B., cited, 31, 32, 117.

Sport, 269, 273.

Social adaptation and religion, see Adaptation.

Social attitudes, see Attitudes, social.

Social control, see Control, social.

Social development, see Evolution, social.

Social education, see Education, social.

Social environment, see Environment, social.

Social groups, see Group.

Social justice, see Justice.

Social ideals, see Ideals.

Social intelligence, see Intelligence and social progress.

Social leadership, see Leadership.

Social mind, 63, 252, 295, 296.

Social obligation, see Obligations, social.

Social order, see Order.

Social organization, see Organization, social.

Social progress, see Progress.

Social reconstruction, see Reconstruction.

Social religion, defined, 43,67 , 162 ; essentials of, 128-131, 161187; genesis of, $42,43,44,66$; and Christianity, 76, 77, 81, 83,84 ; and social science, $162-$ 180 ; and the family, 188-209; and amusements, 264-279; and politics, 243-263; and economio 
conditions, 210-242; and the church, 280-305.

Social retrogression, $15,16,17$.

Social science, defined, $x, 161$; as a support of religion, $x i, 5,30$, $41,90-92,159,162-180,299$; and the teachings of Jesus, 90 . $92,166,177,181-186,207-209$, $241,262,278,298-300$.

Social values, see Values.

Socialism, Marxian, 106, 107, 226. Socialization, 40, 163, 168, 189, 226, 254; of property, 226.

Society, human, nature of, 38, 163,171 ; Christian, 82, 83, 87, $92,115,118,184,209,263,306$. Sociology, $x$, xii, 33, 34, 42, 61, $70,72,76,80,81,140,145,259$, $293,300,303$.

Sociology of religion, 33 .

Socrates, 97.

Son of Man, 146.

Sophists of Greece, 97.

Spaulding, E. G., cited, 9, 140.

Spencer, Herbert, cited, 52.

Spending, ethics of, 239, 240.

Spiritual, defined, 45 ; reality of, $45,46,111,135,136$.

Spirits, see Animism.

State, pagan idea of, $96,103,243$, $244,261$.

Stoicism, 80.

Strong, Josiah, cited, 91, 285.

Subjectivism in religion, 125-127, $132,133,140-142$.

Suffering, human, $60,68,87,114$, $167,176,177$.

Sunday school, the, $287,292,302$, 303.

Sunday observance, 277, 278.

Supernatural in religion, 31,49 , 56.

Supcrstition in religion, $2,22,36$, 43.

Sympathy, social importance of, 168-173, 254-258; in Christianity, $78,84$.

$\mathrm{T}$

Taboo, 48, 55, 65, 131.
Tawney, R. H., cited, 212, 217, 224, 227.

Taxation in Christian society, 238-240.

Teutonic tradition, 97.

Theism, 25, 54, 136, 137.

Theological Christianity, ix, 16, $18,118,286,305$.

Theological element in religion, $x, 12,27,39,59,77,85,118$, 126, $127-159$.

Theology, 7, 12, 13, 18, 20, 26, 39, $59,85,88,118,120,121,127$, $128,138,143,145$.

Thomas, J. B., cited, 84, 85.

Thomas, W. I., cited, 50.

Thomson, J. Arthur, cited, 111, 163.

Todd, A. J., cited, 163, 169.

Toleration, religious, 157, 158.

Totemism, as a form of religion, 25.

Tradition, social importance of, 63,107 ; transmission of, 34 , 62,63 ; conflicts in, $75,99,100$, $101,117$.

Tradition in religion, $4,34,42$, $62,147,186$.

Tribal ethics, 72, 77, 83.

Tufts, J. H., cited, 217.

\section{U}

Unearned incomes, 228, 237-239.

Unemployment, 215, 216, 234, 235.

Understanding, social importance of, 169-172, 255-258.

Union of the Churches, 282-286.

Universe, the, in religious consciousness, $6,26,40,46,54$, 133-137.

Universities and religion, 112, 300.

\section{$\boldsymbol{\nabla}$}

Values, social, ix, 11, 15, 34, 39, $41,42-45,54,59,62-67$; moral, $14,16,53,62$; religious, 13,14 , 
$16,20,39,40-47,53,58,62$, 65.

Vicarious suffering, 178.

Vice, 167, 202, 269.

Votaw, C. W., cited, 78, 80.

\section{W}

Wages, low, 195, 214-216, 235.

War, and social evolution, 71, 118,173 ; and democracy, 259261 ; the stopping of, 116-118, $171,172,173,261$; moral substitute for, 130 .

War, the Great, causes of, vii, 21 ,
103-117; effects of, 22, 37, 94, $115,118,245$.

Ward, Harry F., cited, 211, 235, 310.

Ward, Lester F., cited, 244.

Wealth, proper use of, 100, 212, 239-242 ; distribution of, 222, 223, 227-230, 236, 239.

Webb, C. C. J., cited, 37, 46.

Wells, H. G., cited, 85, 92, 132.

Will, the, see Good will.

Wolfe, A. B., cited, 91.

Woman, position of, 196, 247.

World, as subject of redemption, $129,144,158,186,290$.

Worship, 157, 300, 303. 

$k e y$ 


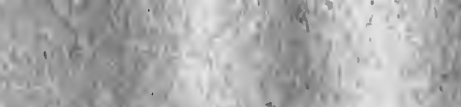

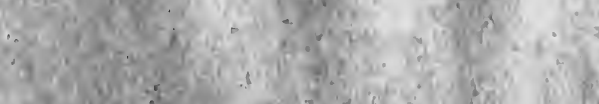

$4+2 x^{5}$

(2)

(i)

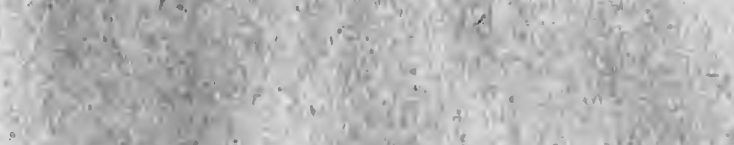

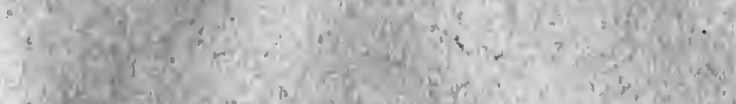

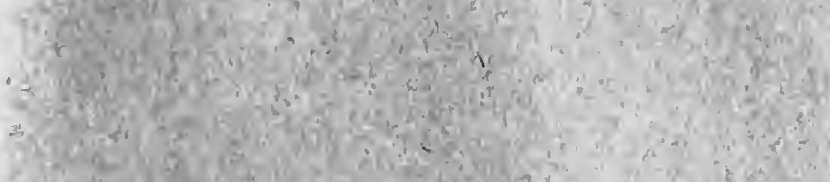

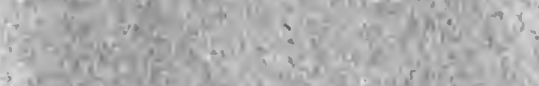

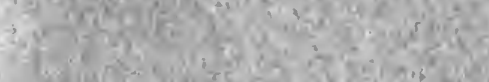

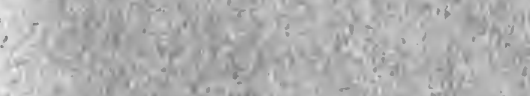

- 8 thes is

west

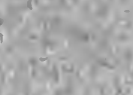

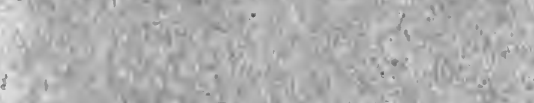

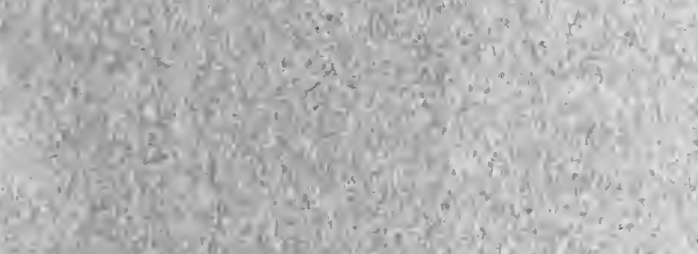

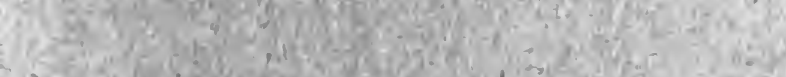

a

$7,1,25,5$ 


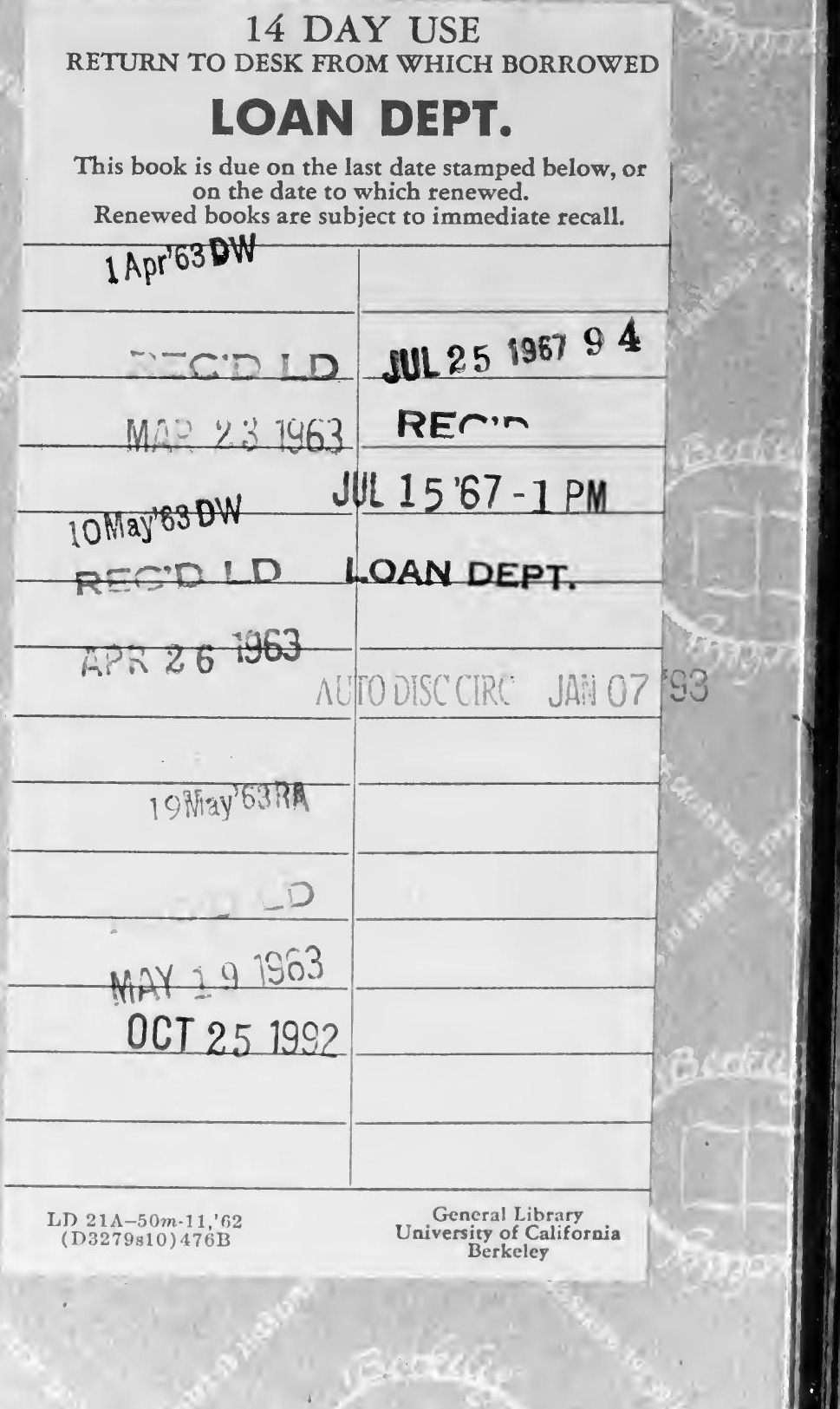


U. C. BERKELEY LIBRARIES

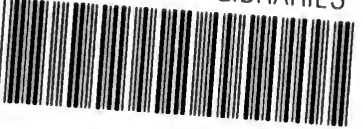
C04]439429 


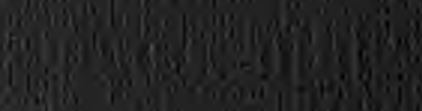

